\title{
A REVISION OF PARABOEA (GESNERIACEAE)
}

\author{
Zhaoran Xu ${ }^{1}$, †B. L. Burtt ${ }^{2}$, L. E. Skog ${ }^{3} \&$ D. J. Middieton ${ }^{2}$
}

The genus Paraboea Ridl. (Gesneriaceae) is revised. It is found in Bangladesh, Bhutan, Burma, Cambodia, southern China, India (Assam), Indonesia (Sumatra, Java, Borneo, Sulawesi), Laos, Malaysia (Peninsular and Borneo), Philippines, Thailand and Vietnam, mostly from limestone habitats. Eighty-nine species and five varieties are recognised. Four new species and one new variety are described: Paraboea apiensis Z.R.Xu, Paraboea argentea Z.R.Xu, Paraboea graniticola Z.R.Xu, Paraboea paraprimuloides Z.R.Xu and Paraboea harroviana var. ovata Z.R.Xu. In addition two taxa are highlighted as possible new species but are not described here due to insufficient material. The treatment includes one new combination for a species, Paraboea harroviana (Craib) Z.R.Xu, one new combination for a variety, Paraboea schefferi var. ambigua (C.B.Clarke) Z.R.Xu, one new status for a variety, Paraboea rufescens var. tomentosa (Barnett) Z.R.Xu, and one new name, Paraboea primuloides Z.R.Xu. Fifty-one line drawings are included. A key is presented and all taxa are described. Preliminary conservation assessments are given.

Keywords. Gesneriaceae, Paraboea, taxonomic revision.

\section{INTRODUCTION}

Paraboea (C.B.Clarke) Ridl. was first published by Clarke as a section, Didymocarpus sect. Paraboea C.B.Clarke (1883), and was raised to generic level by Ridley (1905). Paraboea was distinguished from an allied genus, Boea Lam., by a carpological character: valves of the capsule were straight in Paraboea, while those in Boea were twisted. A revision of Boea and allied genera by Burtt (1984) abandoned the above generic delimitation and circumscribed the two genera based on a difference in indumentum: an indumentum of simple straight hairs in Boea and an indumentum of interwoven arachnoid-like hairs in Paraboea. The revision fundamentally changed the content of the two genera, resulting in a relocation of the majority of species of Boea to Paraboea. Further discussion on generic delimitation in the Boea group (Boea, Paraboea and Trisepalum - including several other genera reduced to synonymy) can be found in Burtt (1984).

This paper is a continuation of an earlier work on Paraboea (Xu \& Burtt, 1991) in which several new taxa were described. It is based on an examination of a total of about 670 herbarium collections with more than 2000 sheets from herbaria all over

\footnotetext{
${ }^{1}$ Sun Yatsen University, PO Box 971, Guangzhou 510275, China. E-mail: dean.shue@gmail.com

${ }^{2}$ Royal Botanic Garden Edinburgh, 20A Inverleith Row, Edinburgh EH3 5LR, Scotland, UK.

${ }^{3}$ Department of Botany, NHB-166, Smithsonian Institution, Washington, DC 20560, USA.
} 
the world. The purpose of this paper is to delimit the taxa, provide a key to identify them, provide a full synonymy, describe each taxon and provide conservation assessments of all taxa. What is now also needed is a thorough phylogenetic analysis of the genus to examine relationships between the species and the relationships of Paraboea to other genera, and indeed, whether Paraboea is a monophyletic group as we have assumed here. Preliminary molecular phylogenetic studies do suggest that Paraboea and Trisepalum together form a monophyletic group but as yet there is no resolution to whether the two genera are distinct or not (M. Möller, pers. comm.). However, this lack of a phylogenetic resolution does not need to delay the fundamental practice of taxonomy which is to delimit and describe species.

Paraboea is found in southern China, northeastern India and the eastern Himalayas, Burma, Thailand, Cambodia, Laos, Vietnam, Malaysia, Philippines and Indonesia as far east as Sulawesi (Fig. 1). Much of this distribution coincides with a poor specimen collection density (Johns, 1995; Middleton, 2003). Consequently many of the taxa included in this revision are known from only one or very few specimens. This inevitably leads to decisions being based on insufficient information, and any use of this work must bear this in mind - there will almost certainly be taxa which we have misinterpreted. We hope, however, that this revision will encourage further exploration of the regions concerned and more targeted collecting of limestone areas where the majority of Paraboea species are found. But, for the time being, we have based our species concept on discontinuities in morphological characters and, where there is some doubt as to whether taxa should be recognised due to inadequate material, we have taken the geographical distributions into account. In addition it is very likely that there are many taxa yet to be discovered, particularly in underexplored limestone areas such as in Laos, Vietnam and Kalimantan.

This paper has been completed in two distinct periods - the majority of the work was done before 1993 by the first author, under the supervision of the second and third authors, and it was then updated and extensively revised by the first and fourth authors in 2007. This work pattern will explain why not all recently collected material is included in the revision although all recently published taxa have been checked and incorporated into the work. Although we acknowledge that in an ideal world all of the recent material should have been included we believe that it is now important that this revision be published to provide a useful benchmark for further taxonomic study on this genus. We have, however, attempted to check the more recent material from particularly poorly known areas.

In this work 89 species and five varieties of Paraboea are recognised, which include four new species, one new variety, one new combination for a species, one new combination for a variety, one new status for a variety and a new name.

\section{MORPHOLOGY}

The genus is rather diverse in morphology, showing differences in habit, the indumentum, the inflorescence and the capsule. We have found inflorescence 


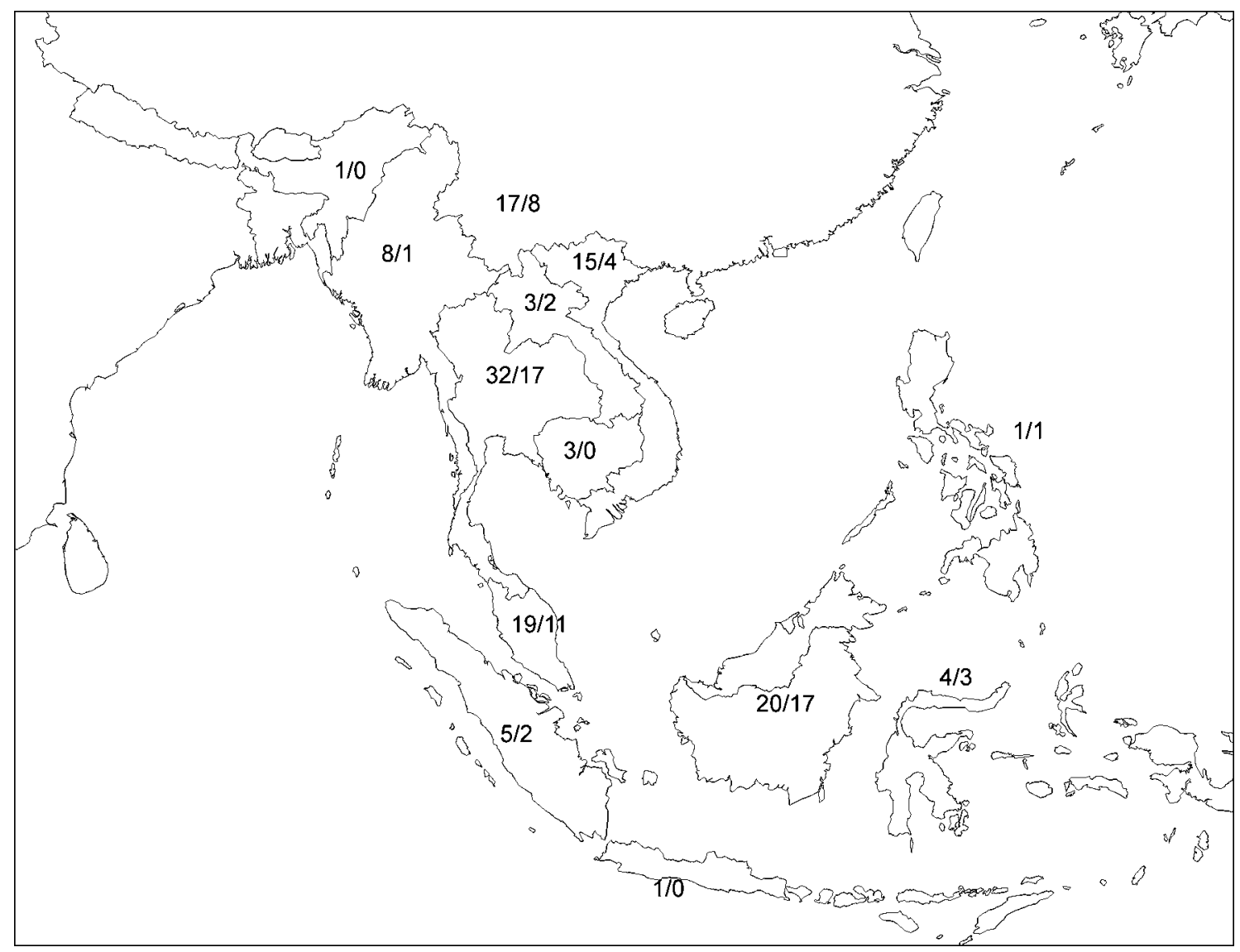

FIg. 1. Distribution of Paraboea species. In each case the first number is the total number of species in the country or on the island (in Malesia) and the second number is the number of endemic species in the same region. Varieties are included under species and species with additional questionable distributions are counted as having specimens found in those areas (see discussions under the relevant species). Paraboea speciosa is not included as its provenance is unknown. The number given for northeastern India also includes Bhutan and Bangladesh. 
structure to be extremely important in identifying species and it will be interesting to see whether it proves to be phylogenetically informative once a molecular phylogeny of the group is available.

\section{Habit: Rosette vs. Cauline with extended internodes}

A rosulate habit (rosette-forming) means that the plants do not possess a stem and all the leaves are basal. A cauline habit means that the plants possess a stem with clear internodes. The rosulate habit and cauline habit may be confused with each other in vegetative growth, for a rosette may be formed by greatly reducing the length of internodes on the stem from the cauline habit. However, in association with inflorescence patterns this confusion may be clarified. A true rosette is generally associated with axillary cymes and the plant has a vegetative terminal bud that will continually grow to produce a polycarpic individual. Species with the cauline habit may also bear an inflorescence of axillary cymes and be polycarpic, but species with a terminal panicle never have a true rosette even though the stem may be very short. These individuals are monocarpic.

Thus, a rosulate habit may not be qualitatively different from a cauline habit, but a rosette + axillary cyme is qualitatively different from cauline habit + terminal panicle.

\section{Leaf phyllotaxis: Opposite vs. Whorled vs. Alternate}

For the most part these three alternative leaf arrangements are clearly distinguishable from each other. Opposite leaf arrangement is the most common in the genus and is associated with both terminal panicles and axillary cymes, and rosulate and cauline habits. Species with whorled leaves almost always have a terminal panicle with only two exceptions (Paraboea divaricata and P. elegans with subterminal cymes) and all these species occur only in tropical Malaysia and Indonesia. This group of species are also similar in habit, in flowers and in fruits. However, even though Paraboea divaricata and P. elegans have whorled leaves they have a similar habit, corolla, stamen and gynoecium to those species with a subterminal cymose inflorescence. Paraboea divaricata is closer to P. patens, and P. elegans to P. minor (see discussions under those species). Alternate leaf arrangement is uncommon in this genus. This leaf arrangement is more often associated with axillary cymes, although $P$. lancifolia has a terminal panicle. The three leaf arrangements have no intermediate types.

\section{Inflorescences: Terminal panicle vs. Axillary cymes vs. Subterminal cymes}

The basic unit in the Gesneriaceae inflorescence is the pair-flower system (for further explanation see Weber, 1973, 1982, 2004). The basic difference between a terminal panicle and an axillary cyme is that the terminal bud in an individual that has 
a terminal panicle will be aborted when the panicle matures while the terminal bud in an individual that has axillary cymes will continue vegetative growth after the flowering season.

Terminal panicle inflorescence. The flowering stem is a direct extension of the plant stem (or the stem of a branch); the cymes in a panicle are arranged in a continual sequence, generally the lower the larger, and every node of the flowering stem usually bears at least one cyme that consists of at least one pair-flower. The leaves in the flowering stem have the same shape and texture as the vegetative leaves.

Axillary cyme inflorescence. There is no flowering stem and the stalk of a cyme is the peduncle. A plant could have several cymes in a flowering season arranged irregularly along the stem with possibly empty leaf axils in the flowering region. The 'leaves' in the cyme, i.e. the bracts, generally have a different shape and texture to the vegetative leaves. In general, the cyme has only two primary branches opposite to each other at the apex of the peduncle. Between the two primary branches there is usually a pair-flower unit. However, in some species (Paraboea clarkei, P. brunnescens), a subordinate primary branch may develop from just below the two primary branches, and subordinate branches may also develop within the secondary branches. Some species, such as Paraboea mahaxayana and P. crassifolia, develop more than one cyme from a single axil.

In addition to the above two basic patterns of inflorescence, we recognise a third pattern of inflorescence, Subterminal cymose inflorescence. In a subterminal cymose inflorescence, the individual plant bears the cymes in the uppermost axils, and the terminal bud, which is a vegetative bud, is aborted after the cymes develop. This may, or may not, produce a monocarpic individual. When the growth is monocarpic (e.g. Paraboea harroviana, P. argentea) subsequent vegetative growth arises from basal buds near the ground or even from rhizomes. When it is non-monocarpic subsequent vegetative growth may resume from the axillary buds below the subterminal cymes. Both patterns may occur in single species. Although this type of inflorescence may seem similar to the terminal panicle the inflorescences never do appear paniculate.

Understanding these three patterns of inflorescence is important. In the family as a whole the axillary cyme is the most common inflorescence type. Almost all the New World Gesneriaceae possess this type of inflorescence, while in the Old World the three types of inflorescence exist with the terminal panicle the least common.

\section{Fruit: Spirally twisted fruit vs. Non-twisted fruit}

In the mature fruit there are two patterns of capsule development: (i) the valves of the capsule spirally twist along the longitudinal axis of the capsule; and (ii) the valves of the capsule are straight. In those that twist the valves may twist around the longitudinal axis more than five times in some long capsules (e.g. Paraboea 
verticillata, $P$. treubii, $P$. paniculata - capsules $>4 \mathrm{~cm}$ long), while in some relatively short capsules (e.g. Paraboea mahaxayana - capsule $<1 \mathrm{~cm}$ long), the valves do not manage a complete turn in their twist. Regardless of whether the capsule is long or short it is easy to distinguish twisting from non-twisting.

Burtt (1984) suggested that fruit twisting was not a reliable character. However, we now believe that the twisting pattern of capsules is a reliable character. In general, the valves of twisted capsules begin to twist at an early stage in the development of the fruit; the ovary itself is always straight. The development of the twisting pattern is generally completed when the young fruit reaches its full length but before the full diameter is attained. Therefore, the twisting pattern is fully developed before the fruit and the seeds are mature. It has also been ascertained that the environment plays no part in whether the capsule twists or not; the twisting is always consistent within a species. In some species the dehisced valves of the fruit may appear to twist even if the fruit itself was straight so the twisting or otherwise of the fruit should be identified before the capsule is open.

More studies are needed to investigate the development of the twist in order to understand why the plants develop such a character. It is assumed that the twisting of the valves is a mechanism for more efficient seed release. For Paraboea and Boea species we may presume that the dry habitat of the limestone substrates on which most species are found may be a factor in the selection of a twisting capsule but the same character is also found in many Streptocarpus species and these are not found in such dry conditions.

All Paraboea species with a terminal panicle have twisted capsules, while all Paraboea species with non-twisted capsules have axillary cymes. However, not all species with axillary cymes have non-twisted capsules.

\section{Indumentum: Matted vs. Arachnoid vs. Simple long pubescence vs. Pubescent vs. Multi-branched (pubescent) hair vs. Glandular and sessile glands}

The indumentum is an important diagnostic character for the genus (Burtt, 1984) and the different types of indumentum can be diagnostic for species (Fig. 2).

Matted indumentum. In Burtt (1984) this indumentum is described as arachnoid indumentum or arachnoid tomentum. We have chosen not to use the term 'arachnoid indumentum' for this type of indumentum because 'arachnoid' suggests 'spider-web-like', a very loose cover of thin hairs. This kind of indumentum, however, is a layer of matted cashmere-wool-like hair. The hair, while very densely appressed, is very thin, curled, and interwoven. Under the scanning electron microscope we can seldom identify a hair from its base to its end and the hairs often branch throughout their length. A hair is generally multicellular. The indumentum exists in almost all Paraboea species with very few exceptions (e.g. Paraboea vulpina) and is primarily located on the lower surface of the leaf. However, it may spread throughout an individual plant except for on the flower. This indumentum is described in the key and the descriptions of taxa in this paper as 


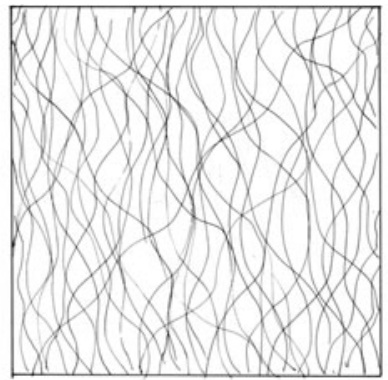

A

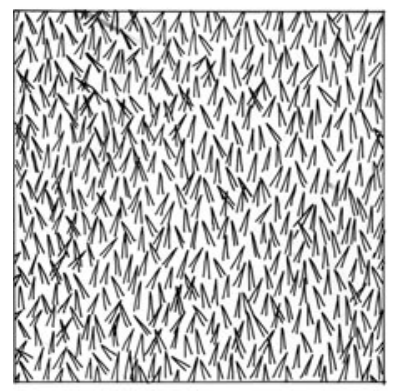

C

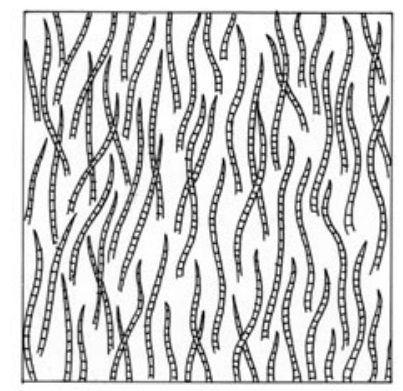

D

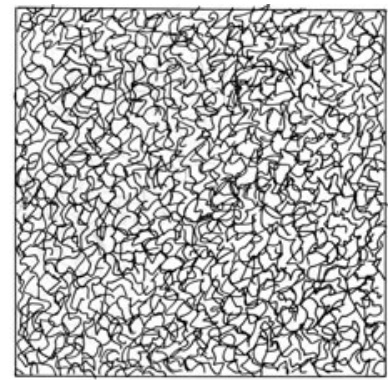

B

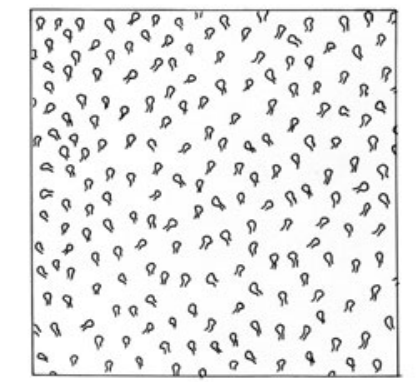

F

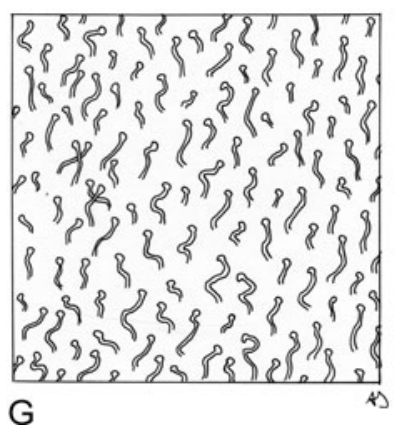

Fig. 2. Indumentum types in Paraboea. A, arachnoid; B, matted; C, simple pubescence; D, simple long pubescence; E, multi-branched hairs; F, sessile glands; G, glandular hairs. See text for further details.

a matted indumentum. The indumentum is also found in many other genera in Gesneriaceae, for example Oreocharis, Hemiboea, Didymocarpus, Trisepalum, Ornithoboea, Rhytidophyllum, etc.

Arachnoid indumentum. This is a spider-web-like indumentum. The hairs are very thin and loosely interwoven with each other. It is distinct from the matted indumentum in that it never forms a dense layer. When individual hairs are examined under the scanning electron microscope both the matted indumentum 
and arachnoid indumentum are seen to be formed from the same kind of hairs, although the hairs may appear thinner in the arachnoid indumentum. The arachnoid indumentum is less common in the genus. A typical example is Paraboea amplifolia.

Simple long pubescence. This is similar to the pubescent indumentum (see below). It is of relatively thick, simple (unbranched) and multicellular hairs but is considerably longer than the simple pubescence and of many cells. It may also be tomentose. This type of indumentum is characteristic for Boea Comm. ex Lam. but a few species of Paraboea also possess it (Paraboea ferruginea, P. laxa, P. vulpina, $P$. tarutaoensis, $P$. scabriflora). It is found on the leaves and stems but rarely on the fertile parts.

Burtt (1984) redefined Paraboea and Boea based on the difference between a matted indumentum and a long (unbranched or simple) pubescent indumentum. These two types of hair are qualitatively different. Plants that possess a matted indumentum are found almost exclusively from limestone substrates, and those with a long (unbranched) pubescent indumentum seem to have no preference for substrate. It is possible that the existence of a matted indumentum on the lower leaf surface provides a mechanism to survive in a dry environment because this dense layer of hairs covers the stomata on the lower leaf surface and reduces water loss by transpiration.

Pubescent indumentum. This is composed of short, stiff, pointed hairs. The hairs are much thicker than those of the matted and arachnoid indumentums. The indumentum is often almost invisible but can be felt with the fingers. The hairs are generally of 2-3 cells and the top cell is often pointed. The pubescent indumentum may be found on the upper surface of the leaf, more often than not, under some arachnoid covering. It is almost never found on the lower surface of the leaf.

Multi-branched hairs. The multi-branched hair is relatively long, stiff, thick hair with many branches which are visible even under the naked eye. Some multi-branched hairs have a long stalk, i.e. the hair always branches some distance from the base, and some do not have a long stalk. The stalk is generally multicellular and the branches are more often multicellular than single-cellular. This kind of hair can be found on the leaves and the stems. Only Paraboea vulpina and P. tarutaoensis possess this kind of indumentum. Because it is so rare, unless otherwise noted below, its absence is to be assumed in the descriptions.

Glandular hairs and sessile glands. Glandular hairs have a stalk that can be of single or multiple cells. Sessile glands do not possess a stalk. These two kinds of indumentum usually occur in the inflorescence although are rarely also found on the leaves. Many species possess glands but they are not of good diagnostic value.

Colour of the indumentum. For identifying species the colour of the indumentum may be useful. The indumentum colour used in the key and in the descriptions refers to dried herbarium specimens, not the colour in fresh plants. 


\section{INFRAGENERIC CLASSIFICATION}

No sectional or infrageneric treatment is offered here for it would be too early to do so, the necessary phylogenetic research having not yet been carried out. However, there is a great deal of morphological variation in the genus and there are recognisable groups of species. We list representative species of these groups here as a marker for future research and a guide to sampling for phylogenetic studies.

Paraboea clarkei - species with straight capsule valves and a spreading inflorescence of axillary cymes [Paraboea sect. Paraboea C.B.Clarke (1883)]; also e.g. P. vulpina, P. laxa.

Paraboea capitata - species with straight capsule valves and a congested capitate inflorescence of axillary cymes [Paraboea sect. Breviflores Ridl. (1905)]; also e.g. P. ferruginea, P. bakeri, P. bintangensis, P. burttii.

Paraboea incudicarpa - with single-celled capsules of straight valves, persistent large bracts and subterminal cymes; this is likely a species of Hemiboea (see discussion under that species).

Paraboea multiflora - species with erect and separate farinose anthers, cymes axillary, capsules twisted, habit rosulate, ovary and style clearly demarcated from each other [Paraboea sect. Caulescentes Fritsch (1894)]; also e.g. P. evrardii.

Paraboea sinensis - species with subterminal cymes, large obovate bracts and sepals, twisted capsules, ovary and style not clearly demarcated from each other.

Paraboea swinhoei - species with a terminal panicle, opposite leaves, campanulate corolla with a short tube and indistinct limb, twisted capsules.

Paraboea martinii - species with a terminal panicle, opposite leaves, corolla with a large swollen tube and a distinct limb, filaments with a bearded knee, capsules twisted; also e.g. P. paramartinii, P. glutinosa, P. thorelii.

Paraboea verticillata - species with a terminal panicle, leaves in whorls of 3-6, campanulate corolla with a short tube and a distinct limb, capsules twisted. This is a rather natural group of tropical species; e.g. P. treubii, P. paniculata, P. nervosissima, $P$. havilandii.

Paraboea harroviana - species with subterminal cymes, opposite leaves, campanulate corolla with a short tube and a distinct limb, capsules twisted; also e.g. P. cochinchinensis, P. prolixa, P. pubicorolla.

Paraboea dictyoneura - species with axillary cymes, rosulate habit, corolla with a large swollen tube and a distinct limb, capsules twisted; also e.g. P. rufescens, $P$. crassifolia, $P$. neurophylla, $P$. hainanensis, $P$. mahaxayana. 


\section{IUCN Conservation Assessments}

Providing accurate IUCN conservation assessments (IUCN, 2001) for all Paraboea species, although highly desirable, is difficult given that so many species are known from only few specimens in undercollected areas. However, given that so many Paraboea species are only known from karst limestone, a habitat endangered throughout East and Southeast Asia due to overexploitation, particularly for cement production (see Clements et al., 2006), it is imperative that the conservation status of these species should be assessed and an appropriate Red List Category assigned even if this will need to be revised later once more accurate data can be gathered. In doing this we have made a number of assumptions. Firstly we assume that species known only from the type or very few specimens really are confined to the area in which they were collected. We acknowledge this is rather a presumption in much of the region, given the low levels of collecting density for many countries (see Middleton, 2003). Secondly we assume that karst limestone habitats throughout the region are threatened (Clements et al., 2006), unless we have specific information that a particular site is in a well-protected national park or other protected area. Lastly we assume that when the plant is known only from the type collection or from very few collections all collected from the same site its extent of occurrence (see IUCN, 2001 for definitions) is $<100 \mathrm{~km}^{2}$. The default category for this then becomes Critically Endangered (CR $\mathrm{Blab}(\mathrm{ii}, \mathrm{iii}, \mathrm{v})$ ) to reflect this limited extent of occurrence, the single location, and the continuing decline in the area of occupancy, the area, extent and quality of habitat, and the number of mature individuals, the declines being inferred from the reductions in karst limestone. The status of Endangered (EN) has been given to a number of taxa which are known from localities additional to the type locality, each with a further explanation there, but the threats given above are also assumed to apply.

The following Red List Category abbreviations are used in the accounts below: $\mathrm{CR}=$ Critically Endangered; $\mathrm{EN}=$ Endangered; $\mathrm{VU}=$ Vulnerable; $\mathrm{LC}=$ Least Concern; and DD = Data Deficient.

\section{The SPecimens}

Geographic coordinates presented in square brackets below have been elucidated from the locality information on the specimen. This distinguishes them from coordinates recorded by the collector. In most cases collectors did not record coordinates, and firmly establishing coordinates for all specimens is not always possible. When there are multiple collections from the same locality the coordinates are given only once. Also, without the help of local people or geographical experts it is easy to misinterpret locality information. We are grateful to the following people for help with locality information: J. E. Vidal (Cambodia, Laos, Vietnam); S. K. Yap (Sabah, Sarawak); R. Kiew (Sabah, Sarawak, Peninsular Malaysia); Halijah Ibrahim (Peninsular Malaysia); J. H. Chou (Taiwan); B. Tan (Philippines); J. F. Maxwell and P. Triboun (Thailand). 
For Chinese localities we have given the Pinyin transliteration of the name to include the tones used (tones 1 to 4) in square brackets; for example 'Yunfou [Yun2fu2]' where 'Yun2fu2' is the Pinyin transliteration with tone indicators.

About 670 collections representing more than 2000 sheets from all of the major herbaria in Asia, Europe and North America were examined.

\section{Systematic Treatment}

Paraboea (C.B.Clarke) Ridl., J. Straits Branch Roy. Asiat. Soc. 44: 4, 63 (1905); Burtt, Notes Roy. Bot. Gard. Edinburgh 41: 422 (1984). - Didymocarpus sect. Paraboea C.B.Clarke in A.DC. \& C.DC., Monogr. Phan. 5: 105 (1883). - Roettlera sect. Paraboea (C.B.Clarke) Fritsch in Engl. \& Prantl, Nat. Pflanzenfam. 4(3B): 148 (1894). - Paraboea sect. Euparaboea Ridl., Fl. Malay Penins. 2: 528 (1923). - Type species: Paraboea clarkei B.L.Burtt, designated by Burtt (1948: 56).

Boea sect. Caulescentes Fritsch in Engl. \& Prantl, Nat. Pflanzenfam. 4(3B): 150 (1894). - Type species: Boea multiflora R.Br., designated by Burtt (1954: 194).

Paraboea sect. Breviflores Ridl., J. Straits Branch Roy. Asiat. Soc. 44 : 64 (1905). - Type species: Paraboea capitata Ridl., lectotype designated by Burtt (1984: 422).

Chlamydoboea Stapf, Bull. Misc. Inform. Kew 1913: 354 (1913). - Type species: Chlamydoboea sinensis (Oliv.) Stapf.

Buxiphyllum W.T.Wang \& C.Z.Gao, Bull. Bot. Res., Harbin 1: 36 (1981). - Type species: Buxiphyllum velutinum W.T.Wang \& C.Z.Gao.

Rosulate or caulescent perennial herbs, often woody at the base, sometimes with straggling woody branches, occasionally monocarpic, young stems at least woolly. Leaves opposite, whorled, or alternately arranged; upper surface glabrous, thinly arachnoid or matted, often glabrescent, or with scabrous hairs; lower surface mostly with a densely matted indumentum, sometimes with hairs of other types (see above). Inflorescence axillary, subterminal or terminal, with pair-flowered cymes. Calyx equally divided almost to base into 5 lobes. Corolla obliquely campanulate or with a short tube and flat limb, clearly to weakly bilabiate, white, blue or violet. Stamens 2 , inserted in the corolla tube; filaments usually thick; anthers robust, bright yellow; staminodes present or not apparent. Ovary more or less cylindrical, distinct or not from the style; stigma usually small, terminal. Fruit a capsule, dehiscent along both margins or only one, straight or spirally twisted, usually cylindrical or slightly flattened, occasionally short with a hump on the upper side at the base.

Distribution. Eighty-nine species and six varieties from Bangladesh, Bhutan, Burma, Cambodia, China, northeastern India, western Indonesia as far as Sulawesi, Laos, Malaysia, Philippines, Thailand and Vietnam. 


\section{Key to the species}

1a. Capsule not spirally twisted 2

1b. Capsule spirally twisted 31

2a. Inflorescence of subterminal cymes, seemingly terminal and capitate; capsules horizontally triangulate, short, c.10 $\mathrm{mm}$ long, swollen to $4 \mathrm{~mm}$ deep near base, held on stiff erect pedicels, and dehiscent along the upper suture [Thailand]

2b. Inflorescence of axillary cymes; capsule \pm cylindric or ovoid

39. $P$. incudicarpa

3a. Leaves with multi-branched hairs 3

3b. Leaves without multi-branched hairs 4

4a. Leaves beneath with multi-branched hairs only; petiole $2-8 \mathrm{~cm}$ long [Peninsular Thailand, Peninsular Malaysia] 89. P. vulpina

4b. Leaves beneath with multi-branched hairs and a matted indumentum; petiole $<2 \mathrm{~cm}$ long [Peninsular Thailand: Tarutao Island] 80. P. tarutaoensis

5a. Leaves densely to very sparsely pubescent above in addition to any arachnoid covering

5 b. Leaves not pubescent above or only with arachnoid covering _ 18

6a. Inflorescence appearing capitate or umbellate

6b. Inflorescence of large or small cymes ___ 11

7a. Capsule shorter than calyx; plant with a pubescence of long simple ferrugineous hairs, especially on petiole and inflorescence, or with a matted indumentum

7b. Capsule $>3$ times as long as calyx; plant with a matted indumentum _ 9

8a. Plant with a pubescence of long simple ferrugineous hairs, especially on petiole and inflorescence [Peninsular Malaysia: Langkawi] 26. $P$. ferruginea

8b. Plant without such a pubescence but with a matted indumentum [Peninsular Malaysia: Pahang] 5. P. bakeri

9a. Sepals obovate, c. $6 \times 4.5 \mathrm{~mm}$ [Peninsular Thailand] _ 11. P. burttii [see also 76. $P$. speciosa, the available material of which is inadequate to properly key out]

9b. Sepals ovate or narrowly ovate, $<3 \mathrm{~mm}$ long 10

10a. Leaf blade \pm ovate, widely cuneate to subcordate at base [Peninsular Malaysia] 14a. P. capitata var. capitata

10b. Leaf blade narrowly obovate, gradually narrowed at base [Peninsular Malaysia] 14b. P. capitata var. oblongifolia

11a. Inflorescence large and lax with $>4$ bifurcations, usually longer than the leaves, subordinate primary branches developed

11b. Inflorescence few-flowered with $\leq 2$ bifurcations, from much shorter to much longer than the leaf, without subordinate primary branches 
12a. Plants truly rosulate; leaves with a long pubescence on upper surface; petiole indistinct, bearing no wings [Peninsular Malaysia: Langkawi; Peninsular Thailand?] 43. P. laxa

12b. Plants rosulate when young and later a woody stem developing; leaves without a long pubescence; petiole distinct, bearing 2 wings in the lower half [Borneo: Sarawak] 17. P. clarkei

13a. Whole plant, even the inflorescence, covered by a true arachnoid indumentum; leaf blade up to $28 \times 13 \mathrm{~cm}$ [Peninsular Thailand]

2. P. amplifolia

13b. Plant without a true arachnoid indumentum or this absent from most of inflorescence; leaf blade up to $18 \times 9 \mathrm{~cm}$ but usually much smaller 14

14a. Capsule as long as or shorter than calyx; capsule glabrous [West Borneo] 55. P. minuta

14b. Capsule $>4$ times as long as calyx; capsule glabrous or with minute glands $\_15$

15a. Capsule with minute glands; leaves minutely pubescent above [Peninsular Malaysia, Peninsular Thailand]

70. $P$. regularis

15b. Capsule glabrous; leaves densely lanate or with a dense matted indumentum above, at least when young 16

16a. Stems with distinct internodes; inflorescence $\leq$ 5-flowered; corolla c.10 mm across [China] 34. $P$. guilinensis

16b. Stems with leaves crowded, without distinct internodes; inflorescence $>5$ flowered; corolla $>10 \mathrm{~mm}$ across 17

17a. Leaves 5-18 cm long; peduncle glabrous [Borneo] 62. $P$. paraprimuloides

17b. Leaves 3-5 cm long; peduncle with a matted indumentum [Borneo] 66. P. primuloides

18a. Inflorescence capitate [Peninsular Malaysia] 14b. P. capitata var. oblongifolia

18b. Inflorescence cymose or laxly umbelliform 19

19a. The first pair of bracts at the apex of peduncle large, $13 \times 9 \mathrm{~mm}$; capsule 1.4 $1.5 \mathrm{~cm}$ long, $<3$ times as long as calyx when this is persistent [Peninsular Malaysia]

8. $P$. bintangensis

19b. The first pair of bracts at the apex of peduncle not so distinct; capsule $0.6-4 \mathrm{~cm}$ long, $\geq 3$ times as long as calyx when this is persistent 20

20a. Leaf blade base peltate (rarely with some leaves on plant not peltate) _ 21

20b. Leaf blade base not peltate___ 22

21a. Leaf blades $1-4 \mathrm{~cm}$ long, margin entire [China] _ 27. P. filipes

21b. Leaf blades $6-33.5 \mathrm{~cm}$ long, margin irregularly crenate-serrate [China] 65. P. peltifolia 
23a. Peduncle with stalked glands (sometimes partially covered with other indumentum) [Philippines]

47. P. luzoniensis

23b. Peduncle without glands or with sessile glands [Borneo] 24

24a. Leaves $>15 \mathrm{~cm}$ long; inflorescence $<15$-flowered

74b. P. schefferi var. ambigua

24b. Leaves $<10 \mathrm{~cm}$ long; inflorescence $>15$-flowered 44. P. leopoldii

25a. Inflorescence to $2.5 \mathrm{~cm}$ long; leaf blades $1.5-2.5 \mathrm{~cm}$ long [China]

87. P. velutina

25b. Inflorescence $8-30 \mathrm{~cm}$ long; leaf blades $2.7-28 \mathrm{~cm}$ long 26

26a. Corolla $\geq 10 \mathrm{~mm}$ across 27

26b. Corolla $<10 \mathrm{~mm}$ across 29

27a. Peduncle with stalked glands (sometimes partially covered with other indumentum) [Philippines]

47. P. luzoniensis

27b. Peduncle without glands or with sessile glands 28

28a. Rosulate herb with basal leaves [China] 59. P. nutans

28b. Sometimes appearing rosulate but leaves crowded at the ends of decumbent or erect stems [Sumatra]

46. $P$. leuserensis

29a. Lower surface of the leaf blade with whitish loose wool, more densely so on the veins and veinlets, making them conspicuously reticulate [Sumatra]

20. $P$. detergibilis

29b. Leaves without woolly reticulate veins 30

30a. Leaf blade $3-7.5 \mathrm{~cm}$ long, base rounded [Sulawesi] 53. P. minahassae

30b. Leaf blade 10-15 cm long, base cuneate [Borneo]

74a. P. schefferi var. schefferi

31a. Inflorescence a terminal panicle with a distinct flowering stem (e.g. Fig. 7), this possibly quite short ${ }^{1}$ 32

31b. Inflorescence of subterminal (e.g. Fig. 44) or axillary cymes (e.g. Fig. 17) with no leaves on flowering stem 58

32a. Leaves alternate; calyx lobes c. $8 \mathrm{~mm}$ long [Peninsular Thailand: Tarutao Island]

42. P. lancifolia

32b. Leaves opposite or in whorls of 3-6; calyx lobe length various 33

33a. Leaves opposite 34

33b. Leaves in whorls of 3 or more 40

34a. The lowest pair of fertile leaves on the flowering stem of similar size to the closest vegetative leaves 35

${ }^{1}$ See also Paraboea argentea which could be mistaken for having a terminal panicle. 
34b. The lowest pair of fertile leaves on the flowering stem of much reduced size, less than half the size of the vegetative leaves 36

35a. Plants with obvious internodes between the leaves; the lowest pair of axillary cymes from leaves well above ground; leaf blade \pm rounded at base [China, Vietnam, Thailand, Philippines, Indonesia]

79. P. swinhoei

35b. Plants seemingly rosulate; the lowest pair of axillary cymes from basal leaves; leaf blade attenuate [China, Burma, Vietnam]

32. P. glutinosa

36a. Leaves with a distinct pubescence above 37

36b. Leaves without a distinct pubescence above 38

37a. Plants with a distinct stem; inflorescence bearing a distinct matted indumentum and the calyx glabrous [Sarawak] 6. $P$. banyengiana

37b. Plants seemingly rosulate; inflorescence bearing no distinct matted indumentum but glandular pubescence, also on the calyx [Laos] 81. P. thorelii

38a. Petiole 0.5-2 cm long [Borneo] 23. P. effusa

38 b. Petiole $3-13 \mathrm{~cm}$ long 39

39a. Inflorescence glabrous; matted indumentum only on the veins below [China] 61. P. paramartinii

39b. Inflorescence with a matted indumentum or a glandular pubescence up to the calyx; matted indumentum evenly covering the whole lower leaf surface [China]

50. P. martinii

40a. Flowering part of main flowering stem relatively short, less than half the length of the lowermost pair of axillary cymes [Sarawak] 77. P. speluncarum

40b. Flowering stem longer than the lowermost pair of axillary cymes 41

41a. Ovary with a minute glandular pubescence which is \pm retained on the capsule 42

41b. Ovary and capsule glabrous 45

42a. Lateral veins on lower leaf surface prominent, spreading at almost rightangles, up to 45 pairs; leaves glabrous above [Peninsular Malaysia] 57. P. nervosissima

42b. Lateral veins not so conspicuous, \pm ascending, $<25$ pairs; leaves pubescent or with some arachnoid covering above 43

43a. Calyx with a matted indumentum; the lowest axillary cymes $<5 \mathrm{~cm}$ long [Southeast Borneo] 40. P. kalimantanensis

43b. Calyx with a glandular pubescence; the lowest axillary cymes $>10 \mathrm{~cm}$ long 44

44a. Inflorescence, pedicel, calyx, ovary and capsule with a ferrugineous glandular pubescence; leaf blade persistently arachnoid above [Peninsular Malaysia, Sumatra] 60. P. paniculata 
44b. Inflorescence covered with a matted indumentum; calyx, ovary and capsule with minute sessile glands [Peninsular Malaysia]

12. $P$. caerulescens

45a. Upper leaf surface with a dense pubescence which is also often covered by some arachnoid indumentum 46

45b. Upper leaf surface without a pubescence under the arachnoid covering 53

46a. Leaf blade rounded to truncate at base; petiole $>1.5 \mathrm{~cm}$ long, about half as long as blade [Sabah]

48. P. madaiensis

46b. Leaf blade attenuate to cuneate at base; petiole not so distinct, much less than half the length of the blade 47

47a. Axillary cymes short, not spreading 48

47b. Axillary cymes long and rather spreading 50

48a. Leaf blades with $>10$ pairs of lateral veins [Peninsular Malaysia]

48b. Leaf blades with $<10$ pairs of lateral veins 9. P. brachycarpa

49a. All lobes of corolla $\geq 3 \mathrm{~mm}$; flowering stem 10-30 $\mathrm{cm}$ long [Borneo] 72. P. sabahensis

49b. All lobes except middle lobe of lower lip of corolla $<2.5 \mathrm{~mm}$ long; flowering stem 6-12(-20) cm long [Sulawesi] 45. P. leporina

50a. Leaf blade $<3$ times as long as wide; lower leaf surface with a silvery loose woolly indumentum [Borneo]

13. $P$. candidissima

50b. Leaf blade $\geq 4$ times as long as wide; lower leaf surface with a brownish to greyish \pm appressed indumentum 51

51a. Calyx without a matted indumentum, only pubescent to glabrous [Sulawesi] 51. P. mataensis

51b. Calyx with a matted indumentum 52

52a. Lateral veins dense, 20-40 pairs; lower leaf surface with an orange-brown matted indumentum [Sumatra - for those specimens of this species possessing these characters]

83. P. treubii

52b. Lateral veins sparse, $<20$ pairs; lower leaf surface with a greyish matted indumentum [Borneo] 38. P. havilandii

53a. Calyx glabrous, or rarely with only a persistent arachnoid covering 54

53b. Calyx with a matted indumentum 56

54a. Leaf blades rounded to shallowly cordate at very base, narrowly ellipticoblong, 25-30 $\times 5-7 \mathrm{~cm}$; up to $3.3 \mathrm{~m}$ tall [Sarawak] 3. P. apiensis

54b. Leaf blades attenuate at base, narrowly elliptic, 5-30 $\times 1.5-7 \mathrm{~cm}$; to $1 \mathrm{~m}$ tall 
55a. Leaf blades 10-30 $\times 3.5-7 \mathrm{~cm}$, indumentum on lower surface yellowish or brownish [Borneo]

23. P. effusa

55b. Leaf blades $2-6.5(-12) \times 0.6-3(-5.2) \mathrm{cm}$, indumentum on lower surface whitish [Borneo]

52. P. meiophylla

56a. Petiole conspicuously swollen at base; upper leaf surface with persistent arachnoid indumentum [Borneo]

7. $P$. berouwensis

56b. Petiole not conspicuously swollen at base; upper leaf surface glabrous or with a loose arachnoid indumentum

57a. Leaf blades usually $4.5-13 \times 1.5-3.5 \mathrm{~cm}$ with a whitish matted indumentum on the lower surface; axillary cymes $<10 \mathrm{~cm}$ long [Peninsular Malaysia]

88. $P$. verticillata

57b. Leaf blades $20-35 \times 3.5-7.5 \mathrm{~cm}$ with a yellowish to greyish matted indumentum on the lower surface; axillary cymes $10-30 \mathrm{~cm}$ long [Peninsular Malaysia, Sumatra, Borneo] 83. P. treubii

58a. Leaves in whorls of 3 or more 59

$58 \mathrm{~b}$. Leaves opposite or alternate or in a rosette 60

59a. Plants \pm rosulate; leaves $15-25 \times 6-9 \mathrm{~cm}$, upper surface densely pubescent; fruit 1-2 cm long [Peninsular Malaysia] 22. P. divaricata

59b. Plants with a distinct stem with clear internodes; leaves 4-9 $\times 1.5-4 \mathrm{~cm}$, upper surface only with arachnoid covering; fruit 2-3 cm long [Peninsular Malaysia, Peninsular Thailand]

24. P. elegans

60a. Leaves alternate or congested at top of a woody stem 61

$60 \mathrm{~b}$. Leaves opposite or in a rosette at ground level 64

61a. Inflorescence of a single flower [possibly an extremely reduced cyme] [Peninsular Thailand] 85. P. uniflora

61b. Inflorescence a cyme or a cymose system of many flowers 62

62a. Leaves alternate on a stem with short internodes; calyx relatively long, more than half as long as the capsule [Peninsular Malaysia] 78. $P$. suffruticosa

62b. Leaves crowded at top of a woody stem without clear internodes; calyx relatively short, less than half as long as the capsule 63

63a. The matted indumentum on leaves brownish and appressed [Peninsular Thailand] 69. P. rabilii

63b. The matted indumentum on leaves whitish and loose [Peninsular Malaysia] 41. P. lanata

64a. The primary bracts (on top of a peduncle) \pm rounded, distinct and large, \pm embracing the inflorescence when young

$64 \mathrm{~b}$. The primary bracts \pm ovate or narrowly so, small and indistinct, not embracing the inflorescence when young 
65a. Inflorescence monochasial [Thailand] 28. P. glabra

65b. Inflorescence dichasial, a true cyme 66

66a. Bracts glabrous, membranous 67

66b. Bracts with an indumentum, papery or leaf-like 68

67a. Stems with distinct internodes; inflorescence a subterminal cyme; sepals $>5 \mathrm{~mm}$ long [China, Vietnam, Burma, Thailand?] 75. $P$. sinensis

67b. Leaves from a rosette; inflorescence axillary from basal leaves; sepals $<2 \mathrm{~mm}$ long [Thailand]

30. P. glabrisepala

68a. Inflorescence with glandular hairs but without a matted or woolly indumentum; lower leaf surface hairy on veins only [Thailand]

31. P. glanduliflora

$68 \mathrm{~b}$. Inflorescence with a matted or woolly indumentum, but no glandular hairs; lower leaf surface with an evenly distributed indumentum 69

69a. Stem and lower leaf surface with a loose woolly indumentum (a combination of a long pubescence and a matted indumentum) [Sumatra] 73. P. scabriflora

69b. Stem and lower leaf surface with an appressed matted indumentum but without a long pubescence 70

70a. Terminal bud aborting after the flowering season; inflorescence subterminal on an elongating stem with distinct internodes [Southern China, northern Vietnam] 84. P. umbellata

70b. Terminal bud continuing its growth after a flowering season; inflorescence in the axil of rosulate leaves 71

71a. The primary and secondary branches of a cyme not developed and so the inflorescence appearing capitate [China] 71a. P. rufescens var. rufescens

71b. The primary and secondary branches of a cyme clearly developed thereby making the inflorescence cymose [Thailand] 71b. P. rufescens var. tomentosa

72a. Ovary and capsule with minute sessile glands, or a glandular pubescence, or a matted indumentum 73

72b. Ovary and capsule glabrous 77

73a. Ovary and capsule with minute \pm greenish sessile glands; anthers with minute \pm yellowish or greenish sessile glands; leaves crowded at top of a short stem or in a rosette 74

73b. Ovary and capsule with a dark brown glandular pubescence or a greyish matted indumentum; anthers glabrous; leaves clearly opposite and the stem with distinct internodes 76

74a. Leaves with a distinct pubescence above; corolla blue [Vietnam] 25. P. evrardii

$74 \mathrm{~b}$. Leaves with or without an indistinct pubescence above; corolla white or in rare cases light purple 75 
75a. Plants rosulate; calyx without a ferrugineous pubescence [China, northeastern India, Bangladesh, Bhutan, Burma, Thailand, Laos, Vietnam]

56a. P. multiflora var. multiflora

75b. Leaves congested at top of the stem; calyx with a ferrugineous pubescence [Thailand]

56b. P. multiflora var. caulescens

76a. Inflorescence, ovary and capsule with a greyish matted indumentum; leaf blade without a pubescence above or only with an arachnoid covering [Peninsular Thailand, Peninsular Malaysia]

1. P. acutifolia

76b. Inflorescence, ovary and capsule with a dark brown glandular pubescence; leaf blade pubescent above [Peninsular Thailand]

86. $P$. variopila

77a. Leaves basal, rosulate; inflorescence a cyme from basal leaves 78

$77 \mathrm{~b}$. Leaves on a distinct stem, usually stem with internodes, leaves mostly distinctly spaced but occasionally clustered; inflorescence a subterminal cyme from axils near the terminal bud 84

78a. Leaf petiole distinct and almost as long as the blade 79

$78 \mathrm{~b}$. Leaf petiole indistinct or very short 80

79a. Leaves drying brown; subordinate branches of a cyme developing [Thailand] 10. P. brunnescens

79b. Leaves drying green; subordinate branches of a cyme not seen [Thailand] 29. P. glabriflora

80a. Capsule $\geq 3 \mathrm{~cm}$ long 81

80b. Capsule $<2 \mathrm{~cm}$ long 82

81a. Veinlets on the lower leaf surface almost invisible [China: Hainan Island]

35. P. hainanensis

81b. Veinlets on the lower leaf surface conspicuously reticulate [China, Vietnam] 21. P. dictyoneura

82a. Cymes 2-5 from an axil; peduncle slender, 0.5-1 $\mathrm{mm}$ in diameter; capsule c. 5-20 mm long [Laos]

49. P. mahaxayana

82b. Cymes 1-2 from an axil; peduncles stout, at least $1.5 \mathrm{~mm}$ in diameter; capsule c. $2 \mathrm{~cm}$ long 83

83a. Leaves \pm attenuate at base; filaments with strongly swollen knees [China: Hubei, Sichuan, Guizhou and Yunnan]

19. $P$. crassifolia

83b. Leaves \pm rounded at base; filaments without knees [Burma, China]

58. P. neurophylla

84a. Petiole $>10 \mathrm{~cm}$ long and with a wing down each side $>3 \mathrm{~mm}$ wide [Thailand] 16. $P$. chiangdaoensis

84b. Petiole mostly $<10 \mathrm{~cm}$ long, if longer than $10 \mathrm{~cm}$ then petiole wing $<1 \mathrm{~mm}$ wide 
85a. Petiole $\geq 10 \mathrm{~cm}$ long [Vietnam] 33. P. graniticola

85 b. Petiole $<8 \mathrm{~cm}$ long 86

86a. Corolla with a glandular pubescence outside; inflorescence glabrous [Thailand, Vietnam?] 68. P. pubicorolla

86b. Corolla glabrous outside; inflorescence glabrous or with an indumentum _ 87

87a. Peduncle $<1.5 \mathrm{~mm}$ in diameter when mature ___ 88

87b. Peduncle c. $2-5 \mathrm{~mm}$ in diameter when mature ___ 91

88a. Inflorescence glabrous [Vietnam] __ 89

88b. Inflorescence pubescent, sometimes glabrescent when older [Thailand, Malaysia] 90

89a. Petiole to $5 \mathrm{~cm}$ long; inflorescence $>15 \mathrm{~cm}$ long; leaves rather clustered [Vietnam]

18. $P$. cochinchinensis

89b. Petiole to $1.7 \mathrm{~cm}$ long; inflorescence $<15 \mathrm{~cm}$ long; leaves not clustered [Vietnam]

36. $P$. halongensis

90a. Corolla white; fruit $<1 \mathrm{~cm}$ long [Peninsular Malaysia]

90b. Corolla blue; fruit $2-2.5 \mathrm{~cm}$ long [Thailand]

63. $P$. parviflora

91a. Leaves sparsely to densely pubescent above 54. P. minor

91b. Leaves glabrous above 92

92a. Inflorescence $\leq 10 \mathrm{~cm}$ long [China] 15. $P$. changjiangensis

92b. Inflorescence $>10 \mathrm{~cm}$ long [Thailand] 93

93a. Inflorescence $\geq 30 \mathrm{~cm}$ long; leaves clustered in a rosette on a short stem [Thailand] 64. $P$. patens

93b. Inflorescence $<30 \mathrm{~cm}$ long; leaves not clustered, internodes $1-7 \mathrm{~cm}$ long [Thailand] 82. P. trachyphylla

94a. Capsule $\leq 1.5 \mathrm{~cm}$ long [Burma] 67. P. prolixa

94b. Capsule $>2 \mathrm{~cm}$ long [Thailand to Vietnam] 95

95a. Individuals producing an extended flowering stem from which numerous axillary cymes develop to give the whole inflorescence the appearance of a terminal panicle; plants with silvery matted indumentum on leaves and inflorescences [Thailand]

4. $P$. argentea

95b. Individuals with only 2 subterminal cymes, and so the inflorescence not having the appearance of a terminal panicle; plants with brownish to greyish matted indumentum [Cambodia, Thailand, Vietnam] 96

96a. Leaf blade ovate, rounded at the apex [Thailand, Vietnam]

37b. P. harroviana var. ovata

96b. Leaf blade elliptic, acute at the apex [Cambodia, Thailand, Vietnam] 
1. Paraboea acutifolia (Ridl.) B.L.Burtt, Notes Roy. Bot. Gard. Edinburgh 41: 423 (1984). - Boea acutifolia Ridl., J. Linn. Soc., Bot. 32: 519 (1896). - Type: Peninsular Malaysia, Kedah, Pulau Langkawi, Gua Chinta [06²0'N 9948'E], iii 1892 (fr), Curtis 2791 (lecto K, designated here; iso SING). Fig. 3.

Perennial caulescent herb; stem woody, c. $30 \mathrm{~cm}$ tall, $0.7 \mathrm{~cm}$ in diameter, with a brownish orange matted indumentum when young, greyish when older; internodes c. $1 \mathrm{~cm}$ long. Leaves opposite, sessile (or with a very short petiole), blade elliptic or narrowly so, or more or less obovate, oblique or not, 9-28 $\times 2-7 \mathrm{~cm}, \mathrm{c} .3-5$ times as long as wide, apex acute, base long-attenuate, margin entire, sometimes inconspicuously serrulate, upper surface with some arachnoid hairs above and some calciumexcretions (volcano-like) or glabrous, lower surface with a brownish orange matted indumentum; veins smooth above, raised beneath, lateral veins c.10-15 pairs, tertiary venation invisible. Inflorescence subterminal, cymose, c.10-20 cm long, many-flowered, rather spreading, with a greyish matted indumentum except for the glabrous corolla, stamens and gynoecium; the two primary branches forked from the peduncle without further bifurcations but monochasially extending into a rather long racemose branch; peduncle up to $8.5 \mathrm{~cm}$ long with indistinct narrowly ovate bracts; pedicels very short, c. $2 \mathrm{~mm}$ long, pedicel bracts sepal-like. Calyx c. $3 \mathrm{~mm}$ long, 5-lobed, lobes narrowly ovate, with a matted indumentum outside, glabrous inside. Corolla pink or white, lobes possibly with a violet vertical stripe, $6 \mathrm{~mm}$ long, $8 \mathrm{~mm}$ across when fully open, glabrous outside and inside; tube very short, 1-2 mm long, limb 2-lipped; upper lip 2-lobed, lobes ovate, c. $5 \times 4 \mathrm{~mm}$, lower lip 3-lobed, middle lobe similar to lateral lobes, wide-ovate, c. $5 \times 5-6 \mathrm{~mm}$. Anthers suborbicular, c. $3 \times$ $4 \mathrm{~mm}$, apex turned towards the gynoecium, coherent with each other, opening along the median line, basifixed, glabrous; filaments inserted at c. $1 \mathrm{~mm}$ from the corolla base with a free part c. $1.5 \mathrm{~mm}$ long, slightly curved, glabrous. Gynoecium c. $7 \mathrm{~mm}$ long; ovary ovoid, c. $3 \times 1 \mathrm{~mm}$, with a matted indumentum; style distinguishable from ovary, glabrous, curving to make the stigma incline towards the anthers. Fruit a linear capsule, c. $1.5 \mathrm{~cm}$ long, spirally twisted, with a greyish matted indumentum.

Distribution. Thailand and Peninsular Malaysia.

Habitat and ecology. On limestone.

Proposed IUCN conservation assessment. Least Concern (LC). This species has been collected at many sites over a wide area and there are no major threats. It is, however, included in Pooma (2005) as threatened in Thailand.

Additional specimens examined. Malaysia. Kedah: Langkawi Islands, P. Dayang Bunting, N end [06 $\left.17^{\prime} \mathrm{N} 99^{\circ} 50^{\prime} \mathrm{E}\right], 28$ iv 1962 (fr), B.L. Burtt \& P.J.B. Woods 1755 (E); P. Langgun, Langkawi, 17 xii 1974 (fr), M.M.J. van Balgooy 2227 (L); Pulau Langkawi, N. Gua [06²0’ N 9948'E], 30 iv 1962 (fr), B.L. Burtt \& P.J.B. Woods 1777 (E); Langkawi, Pulau Ledi (Lidi?), ix 1914 (lv), M. Haniff 1076 (K). Perlis: Bukit Bintang VJR, Rocky hillside [06 $\left.32^{\prime} \mathrm{E} 100^{\circ} 12^{\prime} \mathrm{N}\right]$, 12 viii 1974 (fl), Y.C. Chan 21762 (K, KEP); Bintang Forest Reserve [06 $\left.33^{\prime} \mathrm{N} 100^{\circ} 11^{\prime} \mathrm{E}\right], 26$ iv 


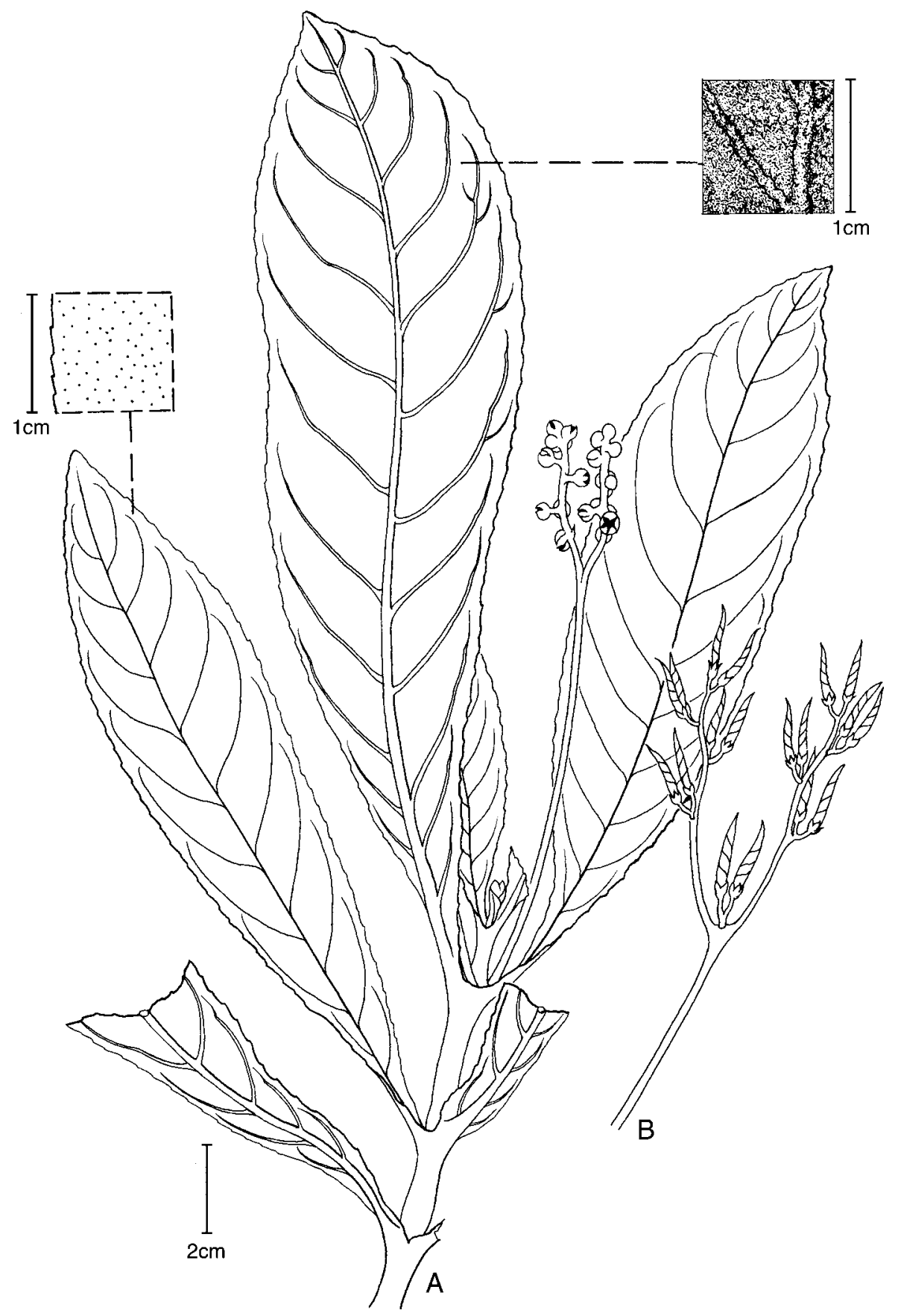

FIg. 3. Paraboea acutifolia (Ridl.) B.L.Burtt. A, habit; B, infructescence. 
1962 (fr), B.L. Burtt \& P.J.B. Woods 1736 (E); Kaki Bukit hills [06 $\left.38^{\prime} \mathrm{N} 99^{\circ} 13^{\prime} \mathrm{E}\right], 25$ iv 1962 (fr), B.L. Burtt \& P.J.B. Woods 1722 (E); Bukit Wang Tangga $\left[06^{\circ} 39^{\prime} \mathrm{N} 100^{\circ} 12^{\prime} \mathrm{E}\right], 20$ xi 1929 (fr), M.R. Henderson SFN 23014 (L).

Thailand. Songkhla: Kao Roop Chang, Padang Besar, District Sadao $\left[06^{\circ} 55^{\prime} \mathrm{N}\right.$ $\left.100^{\circ} 24^{\prime} \mathrm{E}\right], 100$ m, 24 viii 1986 (fl), J.F. Maxwell 86-599 (A); Boriphat waterfall, Rattaphum District $\left[07^{\circ} 04^{\prime} \mathrm{N} 100^{\circ} 08^{\prime} \mathrm{E}\right.$ ], 20 viii 1973 (fl), T. Smitinand 11935 (A, BKF). Phatthalung: Khao Phu Khao Yah, 07040'N 99 50'E, 100 m, 26 x 1993, Larsen et al. 44044 (AAU).

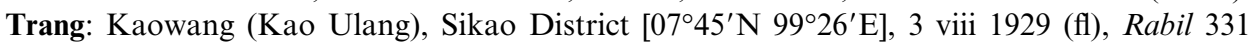
(ABD, E).

This species is characterised by a matted indumentum on the ovary that is retained on the capsule, unique in the whole genus. The excretion of calcium onto the upper leaf surface in many, but not all, specimens is also noteworthy. Paraboea acutifolia is similar to $P$. variopila in inflorescence structure but the latter has glandular hairs rather than a matted indumentum on the ovary and the capsule.

2. Paraboea amplifolia Z.R.Xu \& B.L.Burtt, Edinburgh J. Bot. 48: 1 (1991). - Type: Thailand, Nakawn Sritamarat [Nakhon Sri Thammarat], Kao Chem (Chim), Tunglung (Tungsong) [08 $\left.20^{\prime} \mathrm{N} 99^{\circ} 40^{\prime} \mathrm{E}\right]$, on rocks, 20 vii 1929 (fl, fr), Rabil 123 (holo K; iso ABD, BKF, BM, E). Fig. 4.

Perennial rosulate herb. Leaves petiolate; petiole $2-10 \mathrm{~cm}$ long, covered with true arachnoid indumentum; blades elliptic or ovate, 15-28 $\times 5-13 \mathrm{~cm}, 2-2.5$ times as long as wide, apex obtuse, base cuneate or narrowed, margin entire, membranous, truly arachnoid on both sides, under the arachnoid indumentum with white minute pubescence on the upper surface; veins obscure above, delicately raised beneath, lateral veins c.10 pairs, tertiary venation delicate. Inflorescence axillary cymose, 9-12 $\times 2-5 \mathrm{~cm}$, few-flowered, completely covered by a loose arachnoid indumentum, even the branches of the inflorescence being webbed together by this indumentum; peduncle $7-11 \mathrm{~cm}$ long, c. $1.5 \mathrm{~mm}$ in diameter; pedicels c. $8 \mathrm{~mm}$ long. Calyx c.5 mm long, 5-lobed to the base, lobes linear or nearly so. Corolla white, glabrous, c. $8 \mathrm{~mm}$ across; tube $1.5 \mathrm{~mm}$ long, limb 2-lipped; upper lip 2-lobed, lobes ovate, $4 \times 3 \mathrm{~mm}$, lower lip 3-lobed, lobes of a similar size to the upper lip lobes. Stamens glabrous, anthers transversely ellipsoid, c. $3.5 \times 1.5 \mathrm{~mm}$, coherent with each other, opening in the centre of the anther locules, dorsifixed, apex turning $\left(\mathrm{c} .90^{\circ}\right)$ towards the gynoecium; filaments c. $1.5 \mathrm{~mm}$ long. Fruit ovoid, $0.5 \mathrm{~cm}$ long, $2 \mathrm{~mm}$ in diameter, not twisted, 4-valved when open. Seeds compressed, ovoid, $0.35 \times$ $0.2 \mathrm{~mm}$.

Distribution. Peninsular Thailand. Known only from the type.

Habitat and ecology. Unknown.

Proposed IUCN conservation assessment. Critically Endangered (CR B1ab(ii,iii,v)) see conservation assessment section in introduction. This species was also included in Pooma (2005) as threatened in Thailand. 


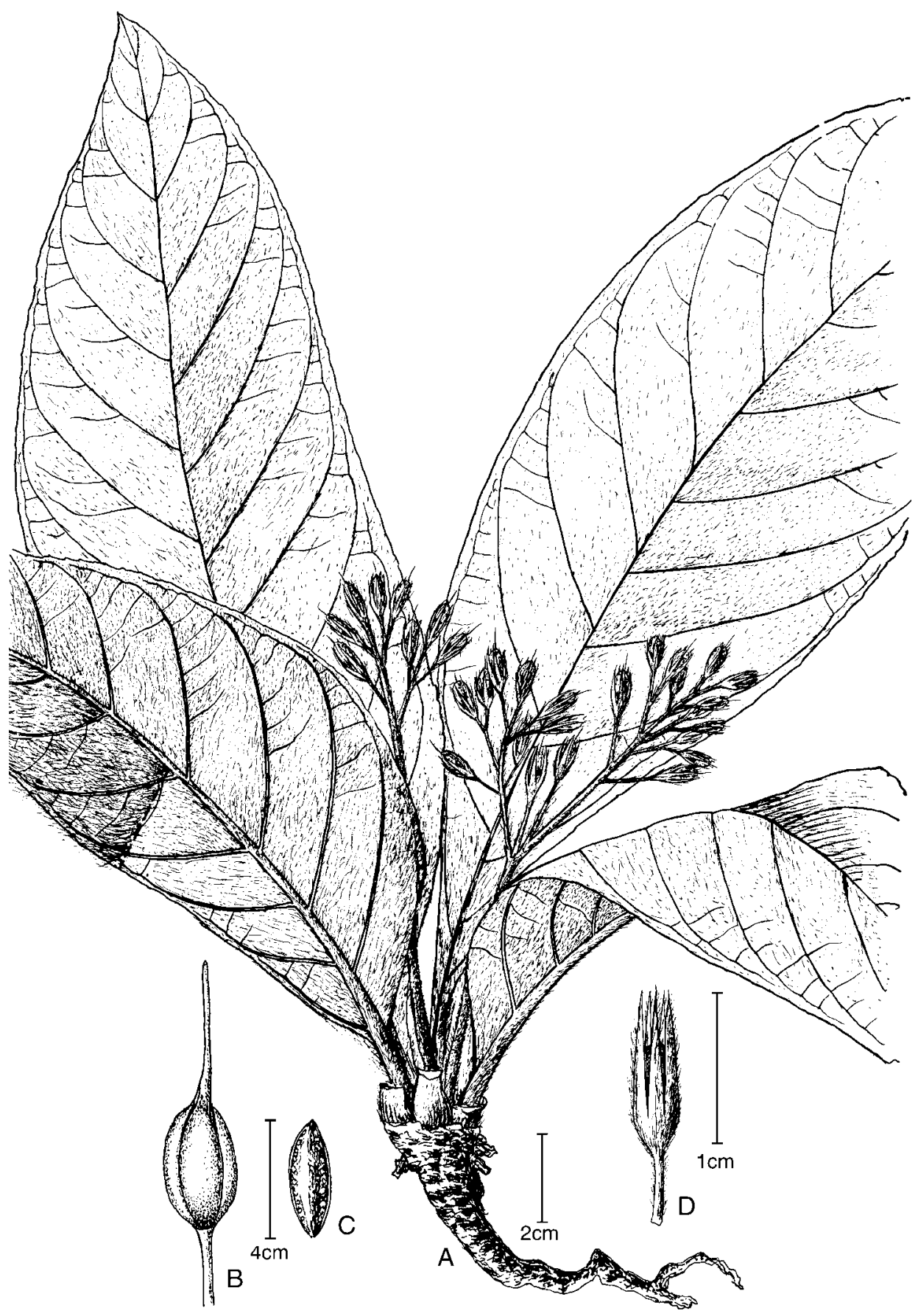

FIg. 4. Paraboea amplifolia Z.R.Xu \& B.L.Burtt. A, habit; B, fruit; C, seed; D, calyx. 
This species is unique in Paraboea by possessing a true arachnoid indumentum covering the whole plant. The large and membranous dried leaves and the small nontwisted capsule are also characteristic.

\section{Paraboea apiensis Z.R.Xu, sp. nov.}

Paraboeae effusae B.L.Burtt proxima, sed inflorescentibus compactis indumentibus foliis base rotundis differt. - Type: Malaysia, Sarawak, Baram District, Ulu Melinau Tutoh, Gunong Api, NE flank of mountain $04^{\circ} 07^{\prime} \mathrm{N} 115^{\circ} 15^{\prime} \mathrm{E}$, limestone cliff, $3200 \mathrm{ft}$ (c.950 m), 2 x 1971 (fl, fr-juv), J.A.R. Anderson S30906 (holo L; iso K, SAR).

Shrub up to $3.3 \mathrm{~m}$ tall. Leaves in whorls of 3, sessile, elliptic-oblong, 25-30 $\times 5-7 \mathrm{~cm}$, apex acute, very base rounded to shallowly cordate, margin entire, upper surface arachnoid and then glabrescent, lower surface with a yellowish matted indumentum; veins smooth above, raised beneath; lateral veins c. 25 pairs, more or less curvedascending, tertiary venation hardly visible. Inflorescence a large terminal panicle, with a matted indumentum throughout except on the flower; flowering stem with ridges, c. $50 \mathrm{~cm}$ long, the basal internodes $\mathrm{c} .10 \mathrm{~cm}$ long, usually 3 cymes from each node; floral leaves similar in shape and texture to the vegetative leaves but reducing in size upward; cymes with c. 20 flowers, peduncle c. $6 \mathrm{~cm}$ long, bracts ovate, c. $6 \mathrm{~mm}$ long; pedicels c.10 mm long. Calyx 5-lobed to the base, glabrous, lobes narrowly ovate, c. $2.5 \times 1 \mathrm{~mm}$. Corolla pale purple, glabrous, c. $15 \mathrm{~mm}$ across when fully open; tube c. $4 \mathrm{~mm}$ long, limb remarkably 2-lipped; upper lip c. $7 \times 14 \mathrm{~mm}$, 2-lobed, lobes wide-ovate, c. $6 \times 7 \mathrm{~mm}$, lower lip wide-obovate, c. $10 \times 12 \mathrm{~mm}$, 3-lobed, middle lobe exceeding the lateral lobes, c. $3 \mathrm{~mm}$, oblong-obovate, c. $4 \times 3 \mathrm{~mm}$. Stamens 2 , staminodes 3, c. $0.2 \mathrm{~mm}$ long; anthers yellow, transversely ellipsoid, c. $2 \times 5 \mathrm{~mm}$, coherent with each other at the apex and the base, opening in the centre of the anther locules, apex turned towards the gynoecium, dorsifixed; filaments inserted at the corolla base with a free part c. $4 \mathrm{~mm}$ long, c. $0.8 \mathrm{~mm}$ wide, \pm verrucose. Ovary ovoid, c. $2.5 \times 1.5 \mathrm{~mm}$; style c. $8 \mathrm{~mm}$ long, $0.4 \mathrm{~mm}$ wide; stigma capitate, not much larger than style. Fruit of a twisted capsule (mature capsules not seen).

Distribution. Malaysia: Sarawak.

Habitat and ecology. On limestone.

Proposed IUCN conservation assessment. Least Concern (LC). The conservation assessment given reflects the fact that although this species is known from very few collections on only one mountain it is inside the Gunung Mulu National Park which is a World Heritage Site and well protected.

Additional specimens examined. Malaysia. Sarawak: Baram District, Gunung Mulu National Park, Gunong Api, 1200 m, 12 vii 1961 (fl), J.A.R. Anderson 4721 (K, SAR); Gunong Api, 5 ix 1970 (fl-bud), P.F. Lehmann S29441 (K, L, SAR).

Although Paraboea effusa is also found at the same locality as this species, $P$. apiensis is easily distinguished by the matted indumentum throughout the 
inflorescence and the rounded to shallowly cordate leaf base. A duplicate of Anderson S30906 at E is apparently a different plant from the other collections listed above.

\section{Paraboea argentea Z.R.Xu, sp. nov.}

Paraboeae harrovianae proxima, sed caule florescentei extenti ad $20 \mathrm{~cm}$, cymis numerosis in pseudo-paniculam, indumentis argenteis differt. - Type: Thailand, Khon Kaen, Pha Nok Khao [16 $\left.30^{\prime} \mathrm{N} 103^{\circ} 00^{\prime} \mathrm{E}\right], 400-500$ m, 10 ix 1963 (fl, fr), T. Smitinand \& H. Sleumer 1141 (holo BKF; iso C, E, L, P).

Perennial herb with an extended flowering stem up to $20 \mathrm{~cm}$ long in flowering individual. Leaves opposite, close to each other towards the base, more remote from each other in the upper part in a flowering individual, petiolate; petiole c. $1-5 \mathrm{~cm}$ long, forming a distinct auricle with the opposite petiole at the node, with a silvery or greyish matted indumentum; blades narrowly elliptic, $2.4-7.6 \times 0.8-1.8 \mathrm{~cm}, 3.6-4.2$ times as long as wide, apex obtuse, base cuneate, rounded to shallowly cordate, margin \pm shallowly serrate, upper surface glabrous, lower surface with a silvery or greyish matted indumentum; veins smooth above, raised beneath; lateral veins $<10$ pairs, spreading, tertiary venation almost invisible. Inflorescence usually of 4 cymes from an elongated flowering stem, which, taken as a whole, looks like a terminal panicle; flowering stem with elongated internodes, c.3-5 cm long; axillary cymes subterminal on the flowering stem, c.10-25 cm long, many-flowered, with a distinct silvery or greyish matted indumentum throughout except on the corolla and the parts inside the corolla; peduncle c.5-15 cm long, quite robust, with bracts sometimes appearing leaflet-like with a short stalk; pedicels short, $<10 \mathrm{~mm}$ long, with bracts sepal-like. Calyx c. $2.5 \mathrm{~mm}$ long, 5-lobed to the base, lobes narrowly ovate, c. $2 \times 0.7 \mathrm{~mm}$, with a silvery matted indumentum outside, glabrous inside. Corolla c. $9 \mathrm{~mm}$ long, $12 \mathrm{~mm}$ across when open; tube c. $4 \mathrm{~mm}$ long, limb 2-lipped; upper lip 2-lobed, lower lip 3-lobed, 5 lobes of similar shape and size except the middle lobe of the lower lip which is slightly larger, widely ovate or rounded, c. $3 \times$ $4.5 \mathrm{~mm}$, glabrous. Anthers reniform, c. $1.5 \times 3 \mathrm{~mm}$, coherent with each other, opening towards the top of the anther, basifixed; filaments inserted at c. $1.5 \mathrm{~mm}$ from the corolla base with a free part c. $2.5 \mathrm{~mm}$ long; staminodes 3. Gynoecium longer than the corolla, c. $1.5 \mathrm{~mm}$ wide at the ovary base; style very short, curved towards the anthers; stigma not enlarged but extremely oblique. Fruit linear, c.3-4 cm long, $2 \mathrm{~mm}$ wide, spirally twisted, glabrous. Seeds ellipsoid, c. $0.6 \times 0.2 \mathrm{~mm}$.

Distribution. Thailand.

Habitat and ecology. On limestone.

Proposed IUCN conservation assessment. Vulnerable (VU D2). This species is currently known from only three collections but these collections are quite widely separated. It may eventually be found in limestone areas between Khon Kaen and Prachuap Khiri Khan but as it is currently known from so few localities, and 
limestone areas in Thailand are often exploited for cement or subject to fires from surrounding agricultural land, it should be considered Vulnerable.

Additional specimens examined. Thailand. Prachuap Khiri Khan: Klawng Warn [Khlong Wan] [1202'N 99³4'E], 16 x 1960 (fl), K. Chandraprasong 63 (BKF); Pran Buri District, Khao Sam Roi Yot National Park, trail from Tham Sai to Tham Phra Yanakhon, $12^{\circ} 11^{\prime} \mathrm{N} 100^{\circ} 01^{\prime} \mathrm{E}$, 110 m, 18 viii 2002, D.J. Middleton et al. 1180 (A, BKF, E).

This new species can be distinguished from Paraboea harroviana by the extended flowering stem, c. $20 \mathrm{~cm}$ long, usually with about 4 cymes, with flowering individuals appearing as if they have a terminal panicle. In addition the very thick layer of silvery matted indumentum is distinctive. In Paraboea harroviana var. harroviana the flowering stem is much shorter and there are often only 2 cymes from opposite axils near the base.

5. Paraboea bakeri M.R.Hend., Gard. Bull. Straits Settl. 7: 115 (1933); Burtt, Notes Roy. Bot. Gard. Edinburgh 41: 424 (1984). - Type: Peninsular Malaysia, Pahang, Bukit Sagu c.18 miles NW of Kuantan, 300 m, in bare dry limestone, 13 x 1931 (fr), Henderson SFN 25094 (lecto SING, designated by Burtt (1984: 424); iso K).

Perennial rosulate herb, lacking any arachnoid covering. Leaves congested in a rosette, with a distinct petiole when mature; petiole $2-5 \mathrm{~cm}$ long with a brown matted indumentum; blades more or less ovate, or in rare cases seemingly obovate, to $7.5 \times 5 \mathrm{~cm}$, apex rounded, base widely cuneate, margin serrate, upper surface with a dense pubescence, lower surface with a brownish matted indumentum, more densely so on the veins; veins slightly depressed above, raised beneath, lateral veins c. 6 pairs, tertiary venation conspicuously reticulate. Inflorescence axillary, seemingly capitate due to the extremely reduced primary and secondary branches, shorter than the leaf, few-flowered, with a brown matted indumentum throughout up to the calyx; peduncle up to $4 \mathrm{~cm}$ long in the infructescence; bracts sepal-like; pedicels c. $10-12 \mathrm{~mm}$ long. Calyx $6.5 \mathrm{~mm}$ long, nearly as long as capsule, 5-lobed to the base, lobes lanceolate, $5 \times 1 \mathrm{~mm}$, obtuse at apex, with a brown matted indumentum outside, glabrous inside. Corolla white, c. $4 \mathrm{~mm}$ long, $4 \mathrm{~mm}$ across, minutely pubescent outside, glabrous inside; tube nearly as long as the whole corolla, limb hardly 2lipped and lobed. Anthers pale yellow, transversely ellipsoid, c. $1 \times 2 \mathrm{~mm}$, opening in the centre of the anther locules, coherent only at the apex, \pm dorsifixed, glabrous; filaments $2 \mathrm{~mm}$ long, erect, inserted $1 \mathrm{~mm}$ from the corolla base; staminodes $<1 \mathrm{~mm}$ long. Gynoecium c. $6.5 \mathrm{~mm}$ long, hairy; ovary $4.5 \times 1.5 \mathrm{~mm}$, smoothly passing to an indistinct style; style $0.5 \mathrm{~mm}$ wide; stigma not larger than style. Fruit a non-twisted capsule, slightly shorter than the calyx, narrowly ovoid, c. $0.5 \mathrm{~cm}$ long, $2 \mathrm{~mm}$ in diameter, with a dense minute pubescence, 4-valved. Seeds more or less ovoid, compressed, brown when dried, $0.35 \times 0.15 \mathrm{~mm}$.

Distribution. Peninsular Malaysia.

Habitat and ecology. On limestone. 
Proposed IUCN conservation assessment. Endangered (EN B1ab(ii,iii,v)). This species is known from only two localities, one of which, the type locality, is the site of an active cement plant. Although the extent of occurrence is clearly $<100 \mathrm{~km}^{2}$, which would justify a Critically Endangered category, the two localities reduces the threat somewhat and Endangered is a more suitable category.

Additional specimen examined. Malaysia. Pahang: Kuantan District, Gua Cheras (c.25 km NW of Kuantan) [103 $\left.20^{\prime} \mathrm{N} 03^{\circ} 50^{\prime} \mathrm{E}\right], 16$ v 1987 (fr), A. Weber 87-0516 (WU).

This species is similar to Paraboea regularis in its habit and in possessing a pubescence on the upper leaf surface. However, the two species are easily distinguished by the difference in the calyx:capsule ratio - in Paraboea regularis it is 1:4 while in P. bakeri it is 1:1. Except for the pubescence on the leaves, Paraboea bakeri is most similar to $P$. bintangensis.

6. Paraboea banyengiana B.L.Burtt, Bot. J. Linn. Soc. 85: 25 (1982); Burtt, Notes Roy. Bot. Gard. Edinburgh 41: 424 (1984). - Type: Sarawak, Gunung Mulu National Park, Burtt 8316 (holo E; iso E, SAR). Fig. 5.

Perennial caulescent herb or semi-shrub to $1 \mathrm{~m}$ tall; stem woody, internodes $1.5-6 \mathrm{~cm}$ long, c. $8 \mathrm{~mm}$ in diameter, with a matted indumentum when young, becoming sparse when older. Leaves opposite, with a petiole c.0.5-3 cm long; blades broad-elliptic, up to $22 \times 8 \mathrm{~cm}$, apex acute, base cuneate, margin serrate, upper surface with a very sparse arachnoid indumentum which sloughs off when mature, lower surface with a matted brown indumentum; veins smooth above, raised beneath, lateral veins c.20 pairs, tertiary venation invisible. Inflorescence terminal, consisting of a lax cymoid panicle, with a brown matted indumentum throughout except on the flower and the upper half of the pedicel; flowering stem up to $30 \mathrm{~cm}$ long, the lowest internode up to $20 \mathrm{~cm}$ long, floral leaves much smaller than the mature vegetative leaves, up to $2.5 \times 0.8 \mathrm{~cm}, 2$ cymes from each node; basal cymes c. $12-18 \mathrm{~cm}$ long, many-flowered but lax, with a peduncle c.5-7 cm long; peduncle bracts narrowoblong, c. 2 times as long as calyx lobes or sometimes similar in size; pedicel bracts sepal-like or even smaller; pedicels c. $10 \mathrm{~mm}$ long, glabrescent. Calyx c. $2.5 \mathrm{~mm}$ long, 5-lobed to the base, lobes narrow-triangular, mostly glabrous. Corolla mauve, mostly glabrous, c. $1.2 \mathrm{~cm}$ long, $1.2 \mathrm{~cm}$ across; tube c. $2 \mathrm{~mm}$ long, limbs spreading; posterior lip 2-lobed, c. $7 \times 7 \mathrm{~mm}$, divided by a sinus $3 \mathrm{~mm}$ deep; anterior lip $10 \times$ $15 \mathrm{~mm}$, 3-lobed, the median lobe $6 \times 5 \mathrm{~mm}$. Stamens 2 , arising at the mouth of the tube, filaments $3 \mathrm{~mm}$ long, muriculate in the middle, more or less flat, straight; anthers yellow, transversely ellipsoid, $1.5 \times 5 \mathrm{~mm}$, coherent with each other at the apex and the base, opening in the centre of the anther locules, dorsifixed. Ovary $5 \mathrm{~mm}$ long, abruptly narrowing into a style of $7 \mathrm{~mm}$ long, glabrous. Fruit a linear, spirally twisted capsule, c. $1.5-2.5 \mathrm{~cm}$ long, glabrous. Seeds ellipsoid, c. $0.8 \times 0.2 \mathrm{~mm}$, with a distinct brown end on one side.

Distribution. Malaysia: Sarawak. 


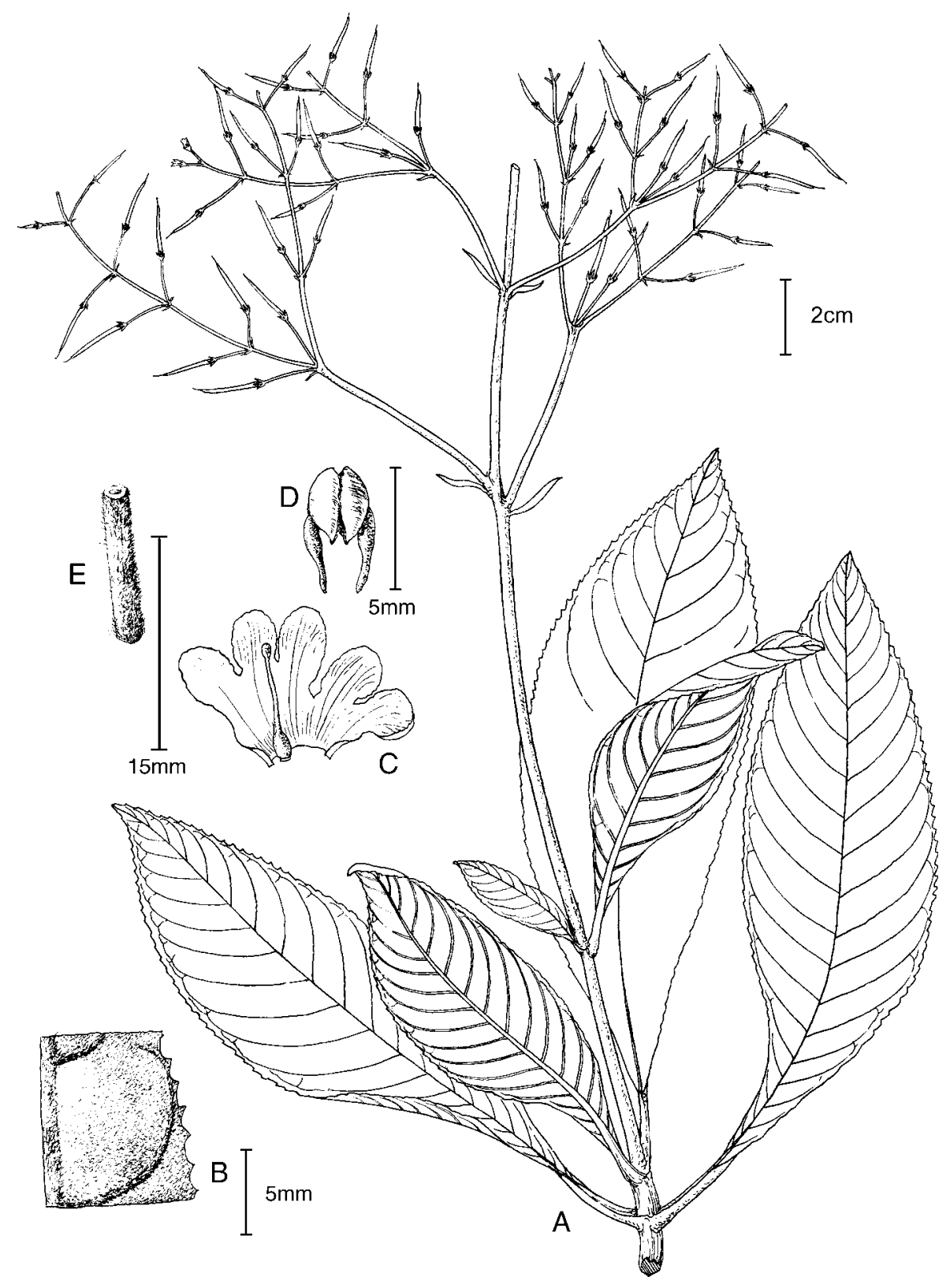

FIG. 5. Paraboea banyengiana B.L.Burtt. A, habit; B, leaf margin; C, corolla opened out; D, stamens; E, section of peduncle. 
Habitat and ecology. On limestone.

Proposed IUCN conservation assessment. Least Concern (LC). The conservation assessment given reflects the fact that although this species is known from very few collections they are all from Gunung Mulu National Park which is a World Heritage Site and well protected.

Additional specimens examined. Malaysia. Sarawak: 4th Division, Baram District, Gunung

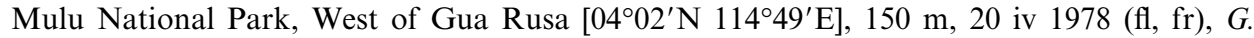

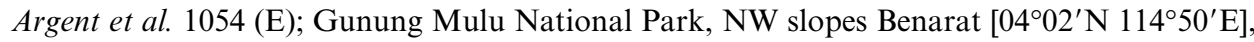
333 m, 18 vi 1975 (fr, fl), B.L. Burtt 8316 (E); Gunung Mulu National Park, Bukit Berar, S Ridge, $04^{\circ} 05^{\prime} \mathrm{N} 114^{\circ} 55^{\prime} \mathrm{E}, 200-250 \mathrm{~m}, 18$ iii 1978 (fl), I. Nielsen 729 (SAR).

Although this species has opposite leaves it is probably related to the other tropical species that have a terminal panicle and leaves in whorls of 3-6, such as Paraboea meiophylla and $P$. verticillata. They all share a similar floral morphology and inflorescence structure.

7. Paraboea berouwensis Z.R.Xu \& B.L.Burtt, Edinburgh J. Bot. 48: 2 (1991). - Type: East Borneo, Kalimantan, Mt. Ilas Bungaan, 600 m, limestone, 10 ix 1957 (fl, fr), A.J.G.H. Kostermans 13785 (holo L).

Perennial caulescent subshrub; stem quite stout, c.1 cm in diameter, internodes $<1 \mathrm{~cm}$ long. Leaves in whorls of 3, petiolate; petioles swollen at the base but not joined to each other across the node, lamina base long-attenuate and extending nearly to the base of the petiole thus the petiole not easily distinguishable from the lamina; blades narrow-elliptic, $11-15 \times 22.5 \mathrm{~cm}$ (including the indistinct petiole), apex shortacuminate, base long-attenuate, margin more or less shallowly serrate, upper surface with some arachnoid covering but otherwise without an indumentum, lower surface with a white matted indumentum; veins obscure above, raised beneath, lateral veins c.13 pairs, tertiary venation invisible. Inflorescence terminal, paniculate, with a white matted indumentum throughout up to the calyx; flowering stem c. $20 \mathrm{~cm}$ long, much thinner than the stem, c. $2 \mathrm{~mm}$ in diameter, floral leaves up to $3.5 \times 0.8 \mathrm{~cm}$, reducing in size upward, 3 cymes from each node; cymes short, $<4 \mathrm{~cm}$ long, many-flowered, congested; pedicel c.2-5 mm long, with bracts sepal-like. Calyx 5-lobed to the base, with a matted indumentum outside, glabrous inside, lobes ovate or narrowly so, 1-2 mm long. Corolla more or less minutely pubescent outside, especially when young, c. $7 \times 10 \mathrm{~mm}$ when open; tube c. $2.5 \mathrm{~mm}$ long, limb 2-lipped; upper lip c. $5 \mathrm{~mm}$ long, 2-lobed, lobes ovate, c. $4 \times 5 \mathrm{~mm}$, lower lip c. $7 \times 9 \mathrm{~mm}$, obovate, 3-lobed, the middle one longer than the lateral lobes by c. $2 \mathrm{~mm}$, more or less oblong, c. $3 \times 2 \mathrm{~mm}$. Stamens 2, distinct; anthers transversely ellipsoid, c. $2 \times 3.5 \mathrm{~mm}$, apex turned towards the gynoecium, opening in the centre of the anther locules, coherent to each other at the apex and the base, dorsifixed; filaments c. $2.5 \mathrm{~mm}$ long, inserted at the base of the corolla, flat, more or less verrucose. Gynoecium glabrous, c. $6 \mathrm{~mm}$ long; ovary $1.5-2 \times 0.6-0.8 \mathrm{~mm}$; style c. $2.5 \times 0.3 \mathrm{~mm}$; stigma capitate not larger than 
style. Fruit c.1-2 cm long, $1.5 \mathrm{~mm}$ wide, spirally twisted, glabrous. Seeds ellipsoid, c. $0.4 \times 0.2 \mathrm{~mm}$.

Distribution. Indonesia: Kalimantan. Known only from the type.

Habitat and ecology. On limestone.

Proposed IUCN conservation assessment. Critically Endangered (CR B1ab(ii,iii,v)) see conservation assessment section in introduction.

In the morphology of the flower and inflorescence this species is similar to Paraboea leporina from Sulawesi but the leaves lack an indumentum below the arachnoid covering on the upper surface and the petiole is swollen at the base.

8. Paraboea bintangensis B.L.Burtt, Notes Roy. Bot. Gard. Edinburgh 31: 51 (1971); Burtt, Notes Roy. Bot. Gard. Edinburgh 41: 424 (1984). - Type: Malay Peninsula, Perlis, Bukit Bintang $\left[06^{\circ} 35^{\prime} \mathrm{N} 100^{\circ} 12^{\prime} \mathrm{E}\right]$, on limestone rocks in evergreen forest, cult. from B.L. Burtt \& P.J.B. Woods 1737 [26 iv 1962 (fr)] in Royal Botanic Garden Edinburgh as Cult. in E C4088 (holo E). Fig. 6.

Rosulate herb. Leaves congested in a rosette, petiolate; petiole 3-7 cm long, with a sparse matted indumentum; blades ovate, elliptic, or slightly obovate or oblong, 4-10 $\times 2-4.5 \mathrm{~cm}$, c.2-2.5 times as long as wide, apex obtuse, base oblique, margin more or less sparsely crenate, glabrescent above, with a greyish matted indumentum beneath; veins obscure above, slightly raised beneath, lateral veins c. 5 pairs, tertiary venation invisible. Inflorescence axillary, appearing umbelliform, c.3-8-flowered; peduncle c.5-8 cm long, with a sparse matted indumentum, the two primary bracts at the top of the peduncle leaf-like, widely ovate, c.13 $\times 9 \mathrm{~mm}$, \pm with some indumentum beneath; pedicels 10-25 mm long, glabrescent. Calyx 5-lobed to the base, lobes narrowly ovate, 5-7 $\times 1.5 \mathrm{~mm}$, \pm ciliate, pubescent outside, glabrous inside. Corolla white, c. $10 \mathrm{~mm}$ long, $15 \mathrm{~mm}$ across, glabrous; tube c. $2 \mathrm{~mm}$ long, limb 2-lipped; upper lip c. $6 \times 8 \mathrm{~mm}, 2$ lobes \pm rounded, c. $5 \times 6 \mathrm{~mm}$, lower lip c. $8 \times$ $15 \mathrm{~mm}$, middle lobes rounded, $4.5 \times 5 \mathrm{~mm}$, lateral lobes similar. Anthers yellow, widely ovate, c. $2 \times 3 \mathrm{~mm}$, opening in the centre of the anther locules, coherent, \pm dorsifixed; filaments c. $2.5 \mathrm{~mm}$ long, swelling in upper $2 / 3$; staminodes $<1 \mathrm{~mm}$ long. Gynoecium $17 \mathrm{~mm}$ long; ovary c. $2.5 \times 1.2 \mathrm{~mm}$; style $0.5 \mathrm{~mm}$ wide; stigma larger than style, c. $1 \mathrm{~mm}$ across. Fruit a linear non-twisted capsule, $1.4-1.5 \mathrm{~cm}$ long, glabrous, 4-valved when open. Seeds not seen.

Distribution. Peninsular Malaysia.

Habitat and ecology. On limestone.

Proposed IUCN conservation assessment. Vulnerable (VU D2). This species is currently known from only two collections but these collections are quite widely separated. It may be found in other limestone areas but as it is currently known from only two sites that are not fully protected it should be considered Vulnerable. 


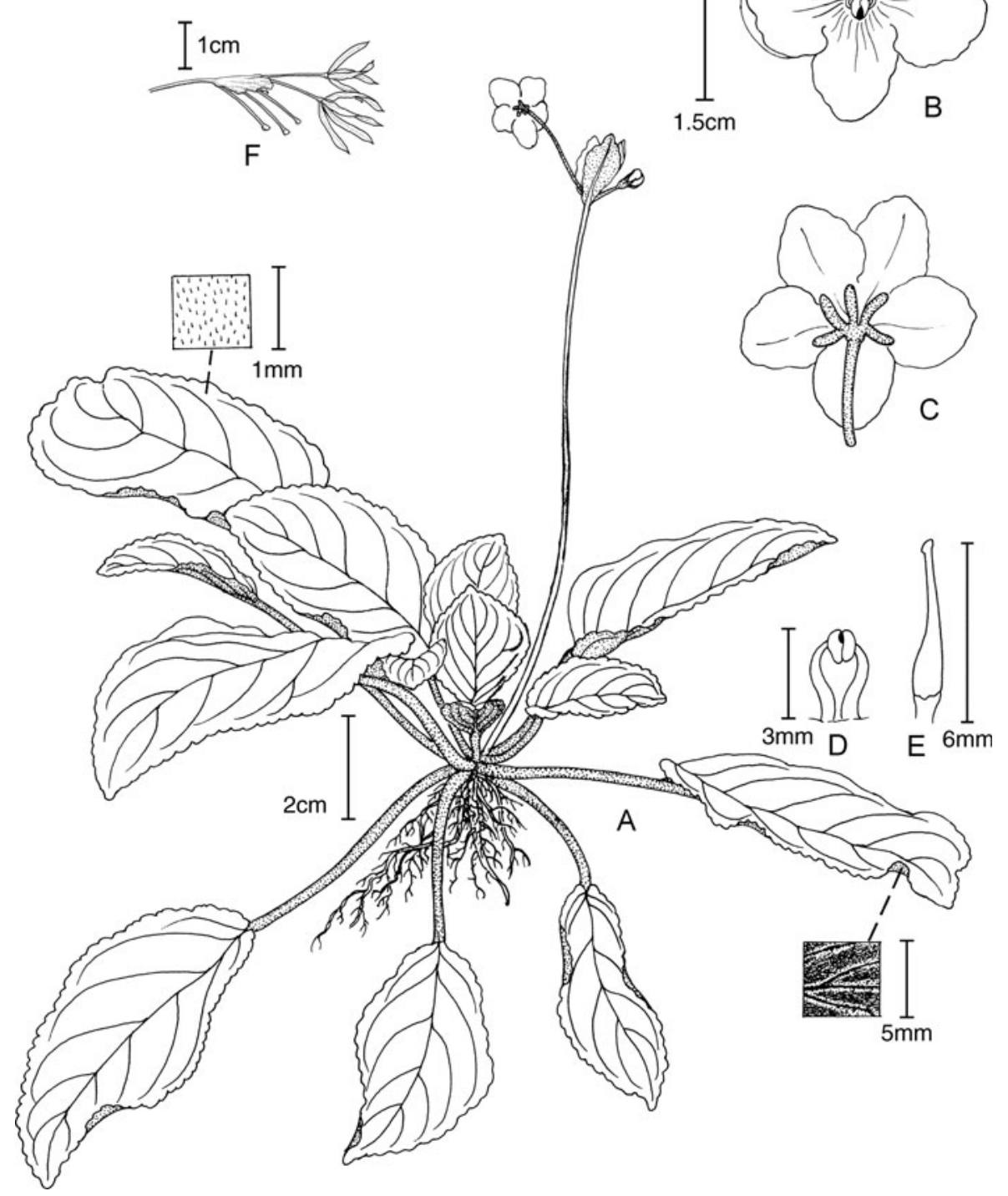

FIg. 6. Paraboea bintangensis B.L.Burtt. A, habit; B, flower; C, flower from behind; D, stamens; E, pistil; F, dehisced fruit. 
Additional specimen examined. Malaysia. Kedah: Pulau Langkawi, Bukit Terbak $\left[06^{\circ} 20^{\prime} \mathrm{N}\right.$ 9948'E], 5 viii 1986 (fl, fr), A. Weber 86-0805 (WU).

The species is easily recognised by its two leaf-like primary bracts. The species may be related to Paraboea bakeri but the latter species possesses no leaf-like bracts and the upper leaf surface has a dense pubescence.

9. Paraboea brachycarpa (Ridl.) B.L.Burtt, Notes Roy. Bot. Gard. Edinburgh 41: 424 (1984). - Boea brachycarpa Ridl., Bull. Misc. Inform. Kew 1929: 259 (1929). - Type: Malay Peninsula, Kelantan, Gua Ninik, 26 x 1927 (fr), M.R. Henderson SFN 19668 (lecto K, designated here; iso SING). Fig. 7.

Perennial caulescent herb or subshrub with a woody stem up to $30 \mathrm{~cm}$ long, stem with internodes up to $6 \mathrm{~cm}$ long, including the inflorescence up to nearly $1 \mathrm{~m}$ tall. Leaves in whorls of 3 or 4, occasionally opposite in young plants; petiole normally short and indistinct, with a brownish matted indumentum or sometimes seemingly villose; blades more or less obovate, or narrowly so, 7-20 $\times 2.5-6 \mathrm{~cm}, \mathrm{c} .2-5$ times as long as wide, apex with a very short acumen or obtuse or rounded, base normally long-attenuate or widely cuneate in rare cases, margin more or less serrulate, upper surface normally with a dense pubescence, rarely glabrescent, lower surface with a whitish to brownish matted indumentum; veins smooth or indistinctly visible above, raised beneath, lateral veins numerous, 16-25 pairs, tertiary venation normally reticulate. Inflorescence terminal paniculate, up to $80 \mathrm{~cm}$ long but normally very narrow, only c. $4-6 \mathrm{~cm}$ wide, with a whitish or brownish matted indumentum throughout except on the flower; flowering stem slender or stout but always with long internodes c.10-20 cm long, pendulous, floral leaves much smaller than vegetative ones, normally $2 \times 0.5 \mathrm{~cm}, 3-4$ cymes from each node; cymes short, c. $4 \mathrm{~cm}$ long, many-flowered, with a peduncle $2-3 \mathrm{~cm}$ long, bracts sepal-like; pedicels 2-5 mm long, with a minute pubescence covered by some matted indumentum or not. Calyx 1.5-2.5 mm long, 5-lobed to the base, lobes ovate or narrowly so, with a minute pubescence. Corolla normally glabrous, rarely with some tiny pubescence outside when in bud, c. $6 \mathrm{~mm}$ long, $9 \mathrm{~mm}$ across when fully open; tube very short, limb 2-lipped; upper lip c. $8 \times 4 \mathrm{~mm}$, with 2 lobes c. $5 \times 2.5 \mathrm{~mm}$, lower lip c. $7 \times$ $7 \mathrm{~mm}$, with 3 lobes, middle lobe c. $2.5 \times 2.5 \mathrm{~mm}$, all 5 lobes \pm rounded. Anthers transversely ellipsoid, c. $2.5 \times 5 \mathrm{~mm}$, coherent with each other at the apex and the base, opening in the centre of the anther locules, apex turned towards the gynoecium, dorsifixed; filaments inserted at c. $1.5 \mathrm{~mm}$ from the corolla base, with a free part c. $3 \mathrm{~mm}$ long, with a serrulate wing. Gynoecium c. $7 \mathrm{~mm}$ long; ovary ovoid, c. $2.5 \times$ $1 \mathrm{~mm}$; style c. $4 \times 0.5 \mathrm{~mm}$; stigma not distinct; all reproductive parts inside the corolla glabrous. Fruit short, spirally twisted, $0.6-1.5 \mathrm{~cm}$ long, c. $1.5 \mathrm{~mm}$ in diameter, glabrous. Seeds ovoid, c. $0.5 \times 0.2 \mathrm{~mm}$.

Distribution. Peninsular Malaysia.

Habitat and ecology. On limestone. 


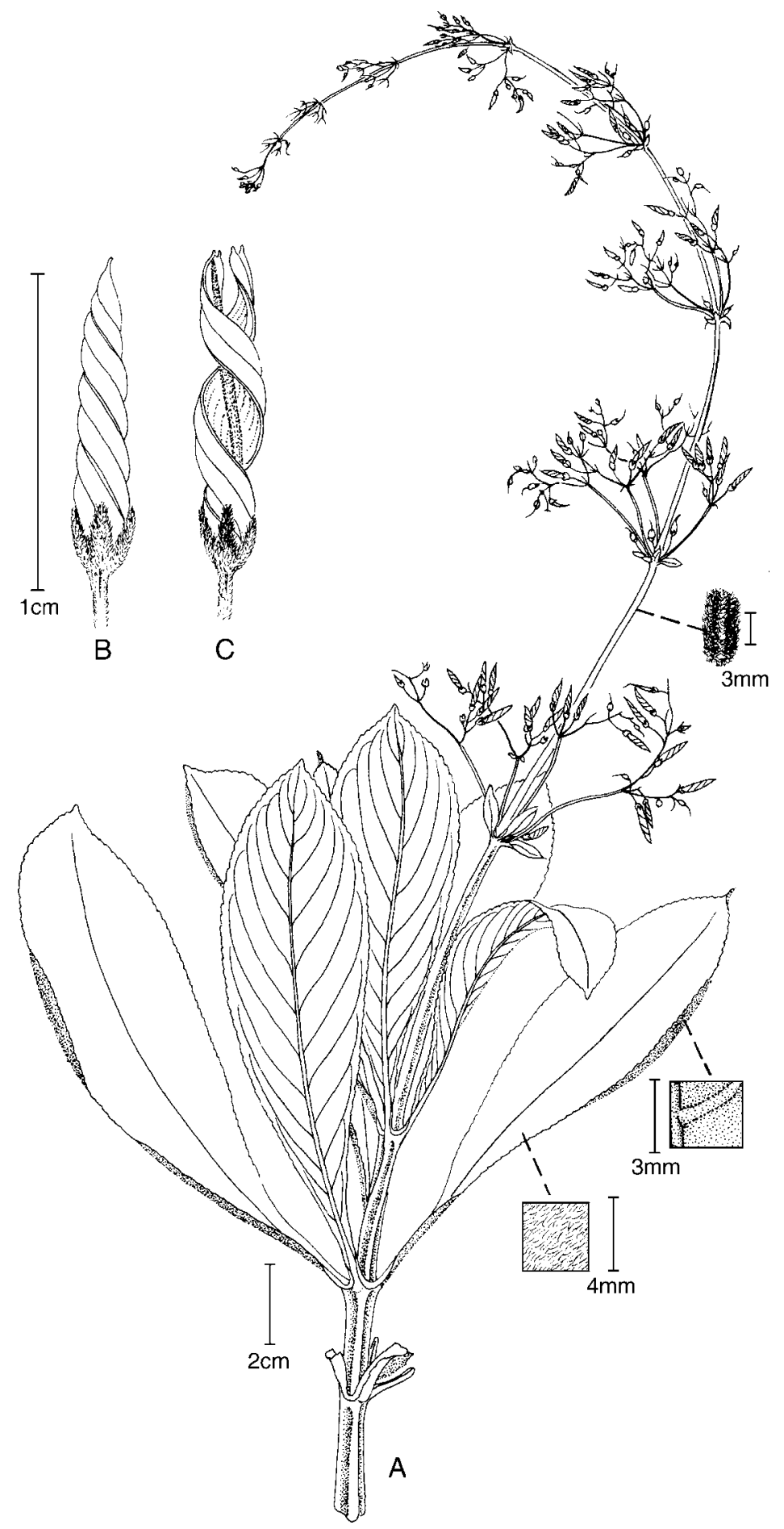

FIG. 7. Paraboea brachycarpa (Ridl.) B.L.Burtt. A, habit; B, fruit; C, fruit dehisced. 
Proposed IUCN conservation assessment. Least Concern (LC). This species has been collected at several sites over a wide area and there are no major threats.

Additional specimens examined. Malaysia. Pahang: Between Bentong and Karak, just away

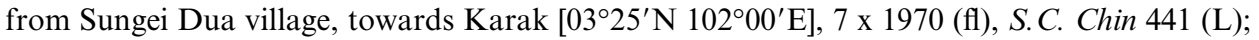

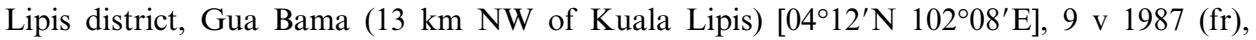
A. Weber 87-0508 (WU), A. Weber 87-0509 (WU); Lipis district, Gua Rusa (limestone area c.40 km S of Gua Musang, S of border Pahang-Kelantan), 10 v 1987 (fr), A. Weber 87-0510

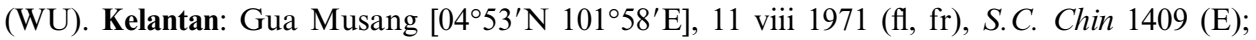

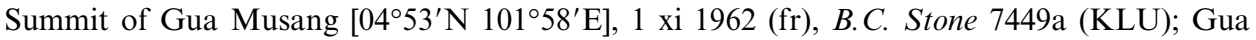
Musang, Ulu Kelantan, 4 viii 1962 (fl), UNESCO Limestone Exp. 303 (SING); Gua Panjang,

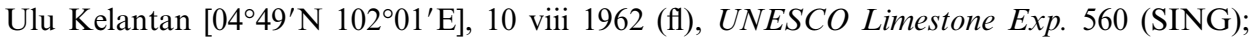
Gua Panjang, Ulu Kelantan, 11 viii 1962 (fl), UNESCO Limestone Exp. 593 (SING); W.

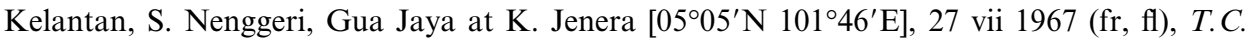
Whitmore 4253 (K, L).

The species is distinctive with its pendulous long panicle, very short lateral cymes, and its very short capsule. This places it in a group of tropical species, such as Paraboea verticillata, that have a terminal panicle and whorled leaves. Ridley (1929) mis-described the species as 'leaves opposite' and compared it with Boea kerrii $(=P$. swinhoei). Even in the type specimen the whorled leaf formation is clear although there is also a young plant that has a few nodes bearing opposite leaves.

The current circumscription of the species encompasses quite some variation: the habit may be caulescent or rosette-like; the upper leaf surface with or without a pubescence; and the calyx with or without some matted indumentum. The pubescence on the upper leaf surface is usually a reliable character for specific delimitation, but occasionally it is not. Most of the duplicates of the three collections recorded from Pahang (Lipis district), A. Weber 87-0509, 87-0510 and 87-0508, are young plants with flower buds and have no distinct pubescence on the upper leaf surface. However, one duplicate of $A$. Weber 87-0509, which was collected from a dead plant with open fruits, shows a dense pubescence on the upper leaf surface. Whether the calyx has a matted indumentum or not is another questionable character in this species. Even within a single specimen (e.g. S.C. Chin 1409) the calyx may or may not have a matted indumentum on the outer surface. It would appear that the flower bud is always covered by this indumentum but when the flower develops the indumentum may or may not remain.

10. Paraboea brunnescens B.L.Burtt, Notes Roy. Bot. Gard. Edinburgh 41: 424 (1984). - Type: Thailand, SW region, Kanchanaburi, Erawan National Park, $14^{\circ} 17^{\prime} \mathrm{N}$ $99^{\circ} 15^{\prime} \mathrm{E}, 400 \mathrm{~m}$, evergreen forest along cascades, on limestone, 18 xi 1971, Beusekom, Geesink, Phengkhlai \& Wongwan 3827a (holo L; iso BKF, C, K, P). There is a typographical error in the protologue where $3827 \mathrm{a}$ is given as $3837 \mathrm{~A}$.

Rosulate herb. Leaves oppositely congested in a rosette; petiole $2.5-12 \mathrm{~cm}$ long, with the same indumentum as that on the lower leaf surface; blades ovate-elliptic, 5-16 $\times$ 3-11 cm, 1.3-2.2 times as long as wide, apex obtuse, base rounded to shallowly 
cordate, margin crenate or weakly so, upper surface sparsely and minutely pubescent, lower surface with a sparse dark brown matted indumentum; veins smooth above, raised beneath, lateral veins c. 6 pairs, ascending at c. $30^{\circ}$ to the midrib, basal veins ascending to halfway or near to the apex of the blades. Inflorescences axillary, cymose, quite lax, several- to many-flowered, normally longer than the leaves, with the same indumentum as that on the lower leaf surface when young and tending to become glabrescent when older; peduncle normally $6-30 \mathrm{~cm}$ long, slender, c.1-2 mm in diameter, primary and secondary branches above the peduncle also relatively long; subordinate branches developing below the primary branches on top of the peduncle; bracts linear, up to $6 \mathrm{~mm}$ long, $2 \mathrm{~mm}$ wide; pedicels 5-15 mm long, very slender. Calyx c.1.5 mm long, 5-lobed to the base, lobes narrowly ovate, c. $1 \times 0.5 \mathrm{~mm}$. Corolla white; tube c. $2.5 \mathrm{~mm}$ long, limb c.10 mm across when open, limb 2-lipped; upper lip 2-lobed with lobes ovate, c. $4 \times 3.5 \mathrm{~mm}$, lower lip 3-lobed with lobes of similar size and shape, c.3.5 $\times 3 \mathrm{~mm}$. Anthers transversely ellipsoid, c. $1.2 \times 3.5 \mathrm{~mm}$, coherent with each other at the apex, opening in the centre of the anther locules, apex pointing towards the gynoecium, dorsifixed; filaments inserted at c. $1 \mathrm{~mm}$ from the corolla base with a free part c. $2 \mathrm{~mm}$ long. Ovary ovoid, c. $2 \times 1 \mathrm{~mm}$; style distinct from the ovary, c. $4 \mathrm{~mm}$ long, $0.2 \mathrm{~mm}$ in diameter; stigma much larger than style. Fruit a linear capsule, 1.5-2.5 cm long, c. $1 \mathrm{~mm}$ in diameter, spirally twisted, glabrous. Seeds ovoid, $3 \times 1.5 \mathrm{~mm}$.

Distribution. Thailand.

Habitat and ecology. On limestone.

Proposed IUCN conservation assessment. Least Concern (LC). This species has been collected at many sites over a wide area and there are no major threats. This species was, however, included in Pooma (2005) as threatened in Thailand.

Additional specimens examined. Thailand. Hard Palom, 250 m, 25 xii 1961 (fr), K. Larsen 8958

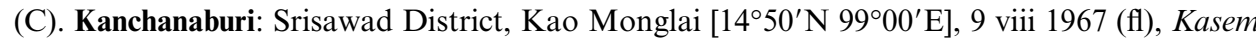

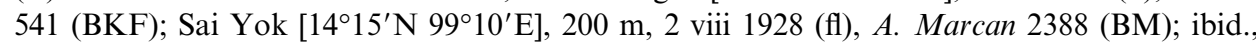
2 viii 1928 (lv), Put 1836 (ABD, BKF, BM, K); Erawan National Park, 14²5' N 9904'E, 300 m, 1 ix 1995, J. Parnell et al. 95-659 (BKF, K, TCD); Erawan Waterfall, 150 m, 10 x 1971 (fl), G. Murata et al. 16164 (L); Khao Salob, 19 viii 1968 (fl), B. Nimanong \& S. Phusomsaeng

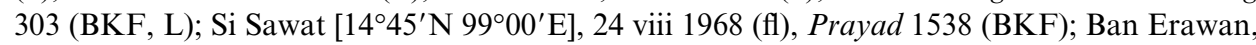
Si Sawat District $\left[14^{\circ} 45^{\prime} \mathrm{N} 99^{\circ} 00^{\prime} \mathrm{E}\right], 250-330 \mathrm{~m}, 2$ xi 1979 (fl), T. Shimizu et al. T-2146 (BKF); Erawan National Park, Si Sawat District, 100-300 m, 3 xi 1979 (fr), T. Shimizu et al.

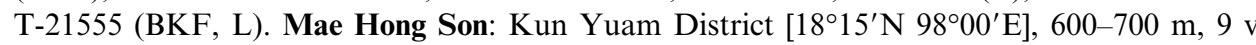
1974 (fr), K. Larsen \& Larsen 34145 (AAU). Sukhothai: Near Pra Tah Due Nahm Doke So Gah Cha Nah Temple, Muang Gow District $\left[17^{\circ} 00^{\prime} \mathrm{N} 99^{\circ} 35^{\prime} \mathrm{E}\right], 4$ xi 1971 (fl, fr), J.F. Maxwell

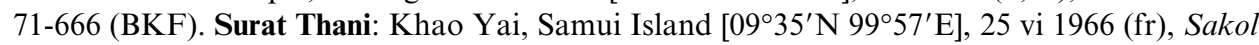
$1116(\mathrm{BKF})$.

This species is extremely similar to Paraboea glabriflora when one compares leaf morphology and inflorescence structure. In addition they are recorded from the same region. There are some differences between the type of Paraboea glabriflora and the 
collections cited above: whitish indumentum vs. dark brown on the leaves; subordinate branches absent or present in the cyme. Paraboea glabriflora is known only from the type so fieldwork should be carried out at the type locality to help determine whether these differences are consistent enough to maintain the species or not.

11. Paraboea burttii Z.R.Xu, Acta Phytotax. Sin. 32: 359 (1994 ['1993']). - Type: Thailand, Nakhawn Srithamarat [Nakhon Sri Thammarat], Khiriwong, Khao Khi Naw [Lansaka District] [08³5'N 9948'E], 400 m, 5 x 1957 (fr), Bunnak 710 (holo E) [Herb common by stream in evergreen forest, flowers bluish].

Perennial rosulate herb with or without a short stem, stem up to $15 \mathrm{~cm}$ long, $7 \mathrm{~mm}$ in diameter (in rock crevices?). Leaves oppositely congested in a rosette, sometimes with $<1.5 \mathrm{~cm}$ long internodes; petiole $4-10 \mathrm{~cm}$ long, with a greyish matted indumentum; blades ovate, $7-14 \times 3-8 \mathrm{~cm}, 1.2-2$ times as long as wide, apex obtuse, base cuneate to shallowly cordate, margin sparsely serrulate (or serrate), densely pubescent above, with a brownish orange matted indumentum beneath (in dried specimens); veins smooth above, raised beneath, lateral veins 6-10 pairs, tertiary venation inconspicuously reticulate. Inflorescences axillary, numerous flowers congested at top of a peduncle, appearing capitate or umbellate, with a matted indumentum throughout the inflorescence up to the calyx; peduncle $13-18 \mathrm{~cm}$ long (usually similar in length to the leaves); bracts numerous, subglobular, c. $1.2 \mathrm{~cm}$ long, embracing the whole inflorescence when young [Note: 'Bracts numerous' is a superficial phenomenon due to the numerous flowers congested at the apex of a peduncle. Actually, each flower usually has only one bract. However, in this species, bractlets below each pedicel are not different to the two primary bracts at the top of a peduncle]; pedicels 10-15 $\mathrm{mm}$ long. Flowers c. $16 \mathrm{~mm}$ across when open. Calyx 5-lobed to the base, \pm with a matted indumentum outside, glabrous inside; lobes obovate, c. $6 \times 4.5 \mathrm{~mm}$. Corolla glabrous, c. $12 \times 16 \mathrm{~mm}$ when open; tube c. $4 \mathrm{~mm}$ long, limb 2-lipped; upper lip 2-lobed, lobes widely ovate, c. $6 \times 10 \mathrm{~mm}$, lower lip 3-lobed, middle lobe obovate, $4 \times 6 \mathrm{~mm}$, lateral lobes widely ovate, $8 \times 9 \mathrm{~mm}$. Stamens 2, glabrous, anthers transversely ellipsoid, c. $2.5 \times 4 \mathrm{~mm}$, the apex turned towards the gynoecium, opening in the centre of the anther locules, coherent at apex and base, dorsifixed; filaments short, inserted at the base of the corolla. Gynoecium glabrous, c. $10 \mathrm{~mm}$ long; ovary ovoid, c. $3 \times 2 \mathrm{~mm}$; style c. $7 \mathrm{~mm}$ long; stigma slightly wider than style, c. $1 \times 1.3 \mathrm{~mm}$. Fruit a linear capsule, $3-4 \mathrm{~cm}$ long, $1.5 \mathrm{~mm}$ wide, glabrous, not spirally twisted, held more or less horizontally, open along the upward valvic line. Seeds ovoid, c. $0.4 \times 0.3 \mathrm{~mm}$.

Distribution. Thailand.

Habitat and ecology. Occurs on shady moist granitic outcrops under evergreen forest.

Proposed IUCN conservation assessment. Least Concern (LC). This species has been collected at many sites over a wide area and there are no major threats. 
Additional specimens examined. Thailand. Province unknown: cultivated in Aberdeen, UK, 1930? (fl), A.F.G. Kerr 205 (K, L). Nakhon Sri Thammarat: Khao Luang, 08 $25^{\prime} \mathrm{N} 98^{\circ} 40^{\prime} \mathrm{E}$, 150 m, 25 x 1991 (fr), K. Larsen et al. 42569 (AAU); Lansagah, Gahrome Falls, Khao Luang National Park [0830' N 9945'E], 150 m, 14 ix 1985 (fl), J.F. Maxwell 85-877 (A, L, PSU); ibid., 13 xii 1985 (fr), J.F. Maxwell 85-1101 (A, L, PSU); ibid., 23 viii 1980 (fl), P. Sirirugsa 328 (PSU); Kao Chem, Tung Song, (local name: Dardhoi) [08²0'N 9940'E], 20 vii 1929 (fl), Rabil 106 (K); ibid., 20 vii 1929 (ster), Rabil 103 (K); Kiriwong, Kiriwong District, Khao

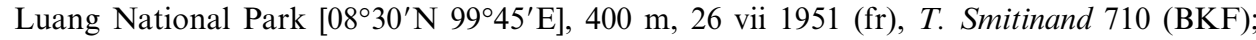
Khao Rawn Nai Hawn, 27 xi 1951 (fl), P. Suvarnakoses 193 (BKF); Hill above Ronpibun [08²2'N 99॰48'E], 100 m, 16 vii 1940 (fl), F.K. Ward 27460 (K). Phatthalung: Tamote District,

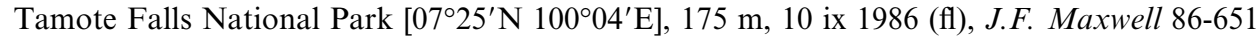
(PSU); Plai Wan Waterfall, $25 \mathrm{~km} \mathrm{SW}$ of Phattalung, $07^{\circ} 25^{\prime} \mathrm{N} 99^{\circ} 55^{\prime} \mathrm{E}, 150-250 \mathrm{~m}, 19 \mathrm{xi}$ 1990 (fr), K. Larsen et al. 41587 (AAU). Trang: Wam Tai, $20 \mathrm{~km} \mathrm{~N}$ of Trang, 11 x 1970 (fr), C. Charoenphol et al. 3640 (E); Bangkok, 3 ix 1930 (fl), A.F.G. Kerr 19745 (K).

This species is similar to Paraboea capitata Ridl., in their capitate inflorescences and horizontally held capsules, but $P$. capitata has no large bracts. With the distinct obovate calyx lobes this species is also similar to Paraboea speciosa but the latter has a different leaf texture and shape. The material for Paraboea speciosa is insufficient for a complete description.

The large obovate calyx lobes of this species are similar to those of Paraboea glabra (Ridl.) B.L.Burtt. Most of the specimens now cited under Paraboea burttii were previously misidentified as $P$. glabra but they differ in the twisting of the fruit in P. glabra.

12. Paraboea caerulescens (Ridl.) B.L.Burtt, Notes Roy. Bot. Gard. Edinburgh 41: 425 (1984). - Boea caerulescens Ridl., J. Straits Branch Roy. Asiat. Soc. 44: 73 (1905). - Type: Malay Peninsula, Perak, Kinta [0436' N 10105'E], 130-200 m, ix 1885 (fl, fr), King's Collector 8276 (lecto K, designated by Burtt (1984: 425)). Fig. 8.

Perennial caulescent subshrub; stem woody, 30-50 cm tall, up to $1 \mathrm{~cm}$ in diameter, internodes normally $1 \mathrm{~cm}$ long, with a white or greyish matted indumentum and later glabrescent. Leaves in whorls of 3 or 4, sessile, narrow-elliptic to somewhat obovate, c. $12-20 \times(2-) 3-6 \mathrm{~cm}, 2.5$ times as long as wide, apex acute or acuminate, base angustate or nearly so, margin entire, upper surface pubescent or glabrous, lower surface with a white or tawny dense matted indumentum; veins smooth above, raised beneath, lateral veins c.12 pairs, tertiary venation invisible. Inflorescence terminal paniculate, with a white or greyish matted indumentum except on the flower; flowering stem 30-70 cm long, the most basal internodes elongated, c. $12 \mathrm{~cm}$ long, floral leaves intermediate to caulescent leaves, gradually reducing in size upward, 3 or 4 cymes from each node; cymes $12 \mathrm{~cm}$ long or less, many-flowered, peduncle bracts narrow-ovate, c. $8 \times 3 \mathrm{~mm}$, pedicel bracts sepal-like; pedicels 5-15 mm long. Flowers with minute capitate pubescence on the calyx, the young corolla outside and the gynoecium, but glabrous on the stamens. Calyx 3-4 mm long, 5-lobed, lobes ovate or narrowly so. Corolla pale mauve-blue or violet, c. $1 \mathrm{~cm}$ long, $1 \mathrm{~cm}$ across; 


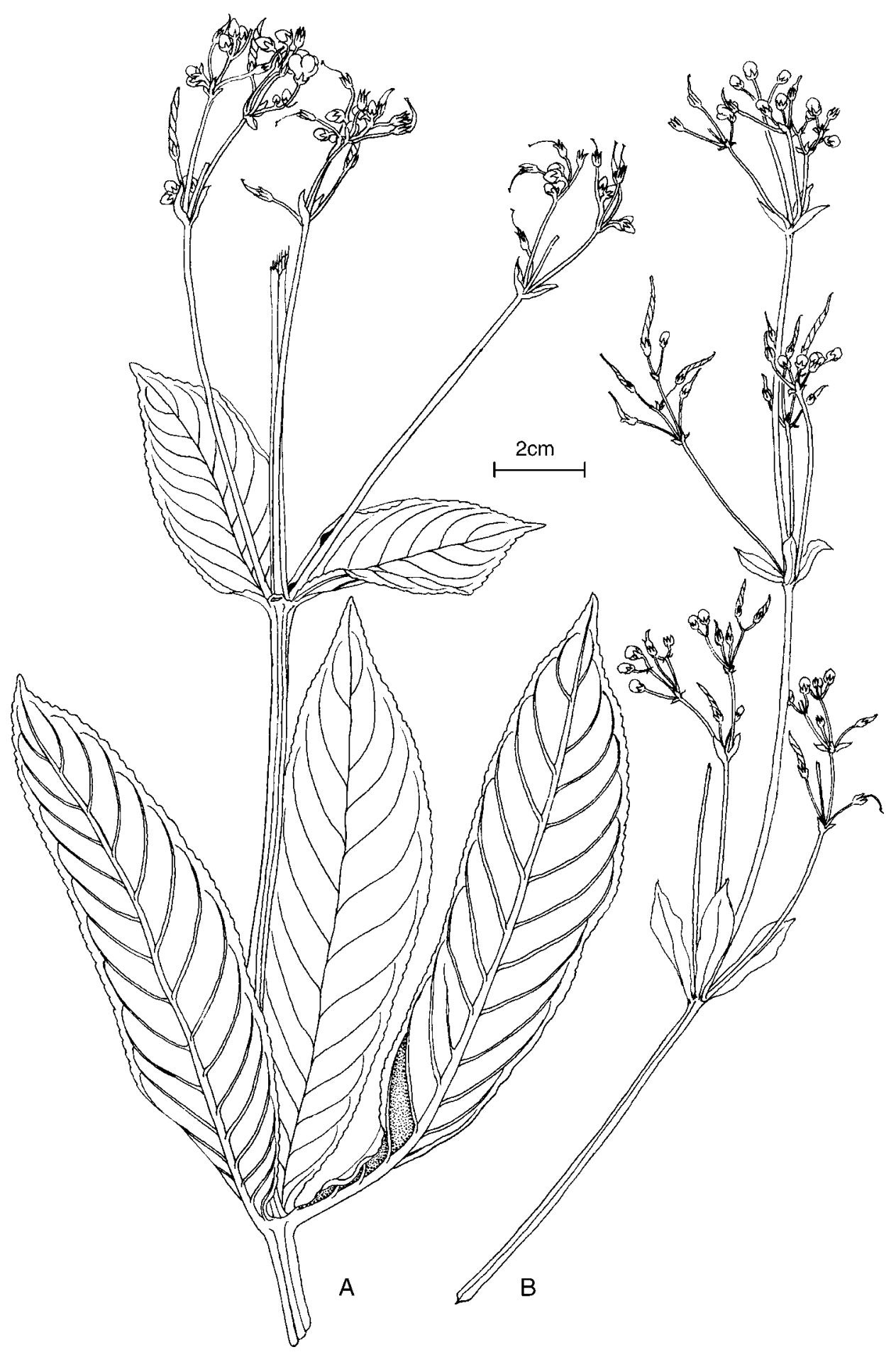

Fig. 8. Paraboea caerulescens (Ridl.) B.L.Burtt. A, habit; B, continuation of inflorescence. 
tube 3-3.5 mm long, limb 2-lipped; upper lip $3 \mathrm{~mm}$ long, 2-lobed, lobes wide-ovate, c. $3 \times 4.5 \mathrm{~mm}$, lower lip $8.5 \mathrm{~mm}$ long, 3-lobed, middle lobe rounded, c. $3 \times 4 \mathrm{~mm}$, lateral lobes wide-ovate, c. $2 \times 4 \mathrm{~mm}$. Anthers yellow, transversely ellipsoid, c. $2.5 \times$ $5 \mathrm{~mm}$, coherent with each other, opening in the centre of the anther locules, apex pointing towards the gynoecium, dorsifixed by the filaments; filaments inserted at the corolla base with the free part c. $3 \mathrm{~mm}$ long, crenate on the margin. Gynoecium c. $7.5 \mathrm{~mm}$ long, $1.2 \mathrm{~mm}$ wide; stigma slightly larger than style. Fruit a spirally twisted capsule, c.1.5-3 cm long, $2 \mathrm{~mm}$ wide, with minute capitate pubescence. Seeds ellipsoid, $0.5 \times 0.15 \mathrm{~mm}$.

Distribution. Peninsular Malaysia.

Habitat and ecology. On limestone.

Proposed IUCN conservation assessment. Least Concern (LC). This species has been collected at several sites over a wide area and there are no major threats.

Additional specimens examined. Malaysia. Perak: i 1921 (fl, fr), H.N. Ridley s.n. (K); Ipoh, Gunong Panjang [0436 $\left.6^{\prime} \mathrm{N} 101^{\circ} 08^{\prime} \mathrm{E}\right], 19$ iv 1962 (fr), B.L. Burtt \& P.J.B. Woods 1659 (E); 14 miles $\mathrm{S}$ of Ipoh just off main road to Kuala Lumpur, Gunong Kandu [04 $\left.36^{\prime} \mathrm{N} 101^{\circ} 05^{\prime} \mathrm{E}\right]$, 5 v 1962 (fl, fr), B.L. Burtt \& P.J.B. Woods 1822 (E); (fl), Cult. in E C4912 (E); (fl), Cult. in E C5978 (E). Pahang: Bukit Cheras, near Kuantan, 170 m, 11 x 1931 (fl, fr), M.R. Henderson s.n. (K).

Some variation within the species has been found. The type and B.L. Burtt \& P.J.B. Woods 1659 have a pubescent upper leaf surface. Another group of collections, such as B.L. Burtt \& P.J.B. Woods 1822 and H.N. Ridley s.n. (i 1921), have no pubescence on the upper leaf surface. In addition, M.R. Henderson s.n. (11 x 1931) from Pahang is similar to the latter group but it has an arachnoid covering on the upper leaf surface. However, there are no other characters to separate these collections into different taxa.

This species is a large caulescent subshrub with a whorled leaf formation and a large terminal paniculate inflorescence, like a dozen other species in Borneo and Peninsular Malaysia. The minute capitate pubescence on the calyx and the fruit and the absence of a matted indumentum on the calyx are characteristic in this species. See also discussion under Paraboea paniculata.

13. Paraboea candidissima B.L.Burtt, Bot. J. Linn. Soc. 85: 26 (1982); Burtt, Notes Roy. Bot. Gard. Edinburgh 41: 425 (1984). - Type: Sarawak, Gunung Mulu

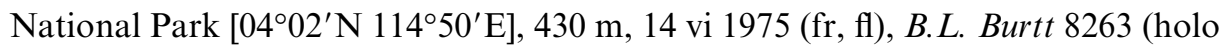
E (over 2 sheets); iso SAR). Fig. 9.

Subshrub; stem woody, elongated, straggly, with a few branches towards the base, with living leaves only towards the apex, those in the middle being withered or persisting solely as petioles, base of the stem bare, when young white lanate and then becoming rusty-brown with a thinner indumentum, internodes $0.5-3.5 \mathrm{~cm}$ long, up to $1 \mathrm{~cm}$ in diameter. Leaves in whorls of 3, opposite pairs occasionally 


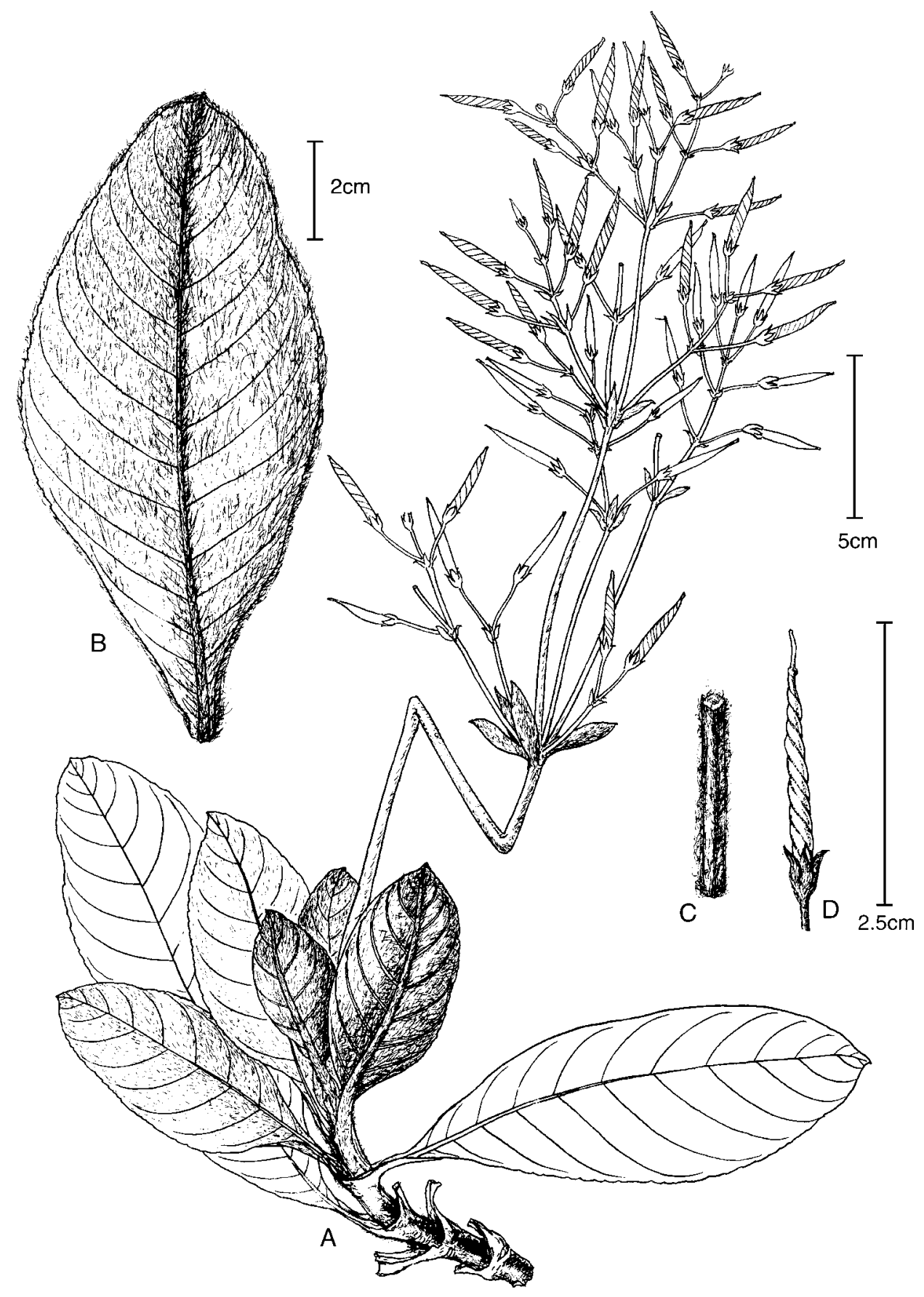

FIG. 9. Paraboea candidissima B.L.Burtt. A, habit; B, leaf; C, section of peduncle; D, fruit. 
seen; petiole scarcely distinct from the lamina, 1.5-2 cm long (but juvenile leaves subsessile), the base subauriculate and joining across the node, with the same indumentum as the blades; blades broadly elliptic or somewhat obovate-elliptic, c. $10-15 \times 4-8 \mathrm{~cm}$, c. 2 times as long as wide, apex obtuse, base angustate, margin entire or very slightly serrulate, upper surface with a pubescence of a white arachnoideous layer, lower surface with a white lanate indumentum; veins smooth above, raised beneath, lateral veins 14-17 pairs, tertiary venation invisible. Inflorescence terminal paniculate, with a white lanate indumentum throughout except on the corolla, the stamens and the gynoecium; flowering stem c.35-40 cm long, basal internodes rather long, up to $15 \mathrm{~cm}$ long, making the inflorescence rather lax; floral leaves much smaller than cauline leaves, up to $3 \times 1.5 \mathrm{~cm}$ (in one case $7 \times 4 \mathrm{~cm}$ ), usually 3 (and rarely 2) cymes from each node, cymes up to $20 \mathrm{~cm}$ long, ascending, peduncle or pedicel bracts similar to calyx lobes or indistinctive; pedicels c.10-25 mm long, in pairs. Calyx c.5 mm long, 5-lobed, lobes narrowovate, outside with a white sublanate indumentum, inside glandular. Corolla pale violet, the buds lightly covered with a white-arachnoid indumentum; tube $1.5 \mathrm{~mm}$ long, limb 2-lipped; posterior lip c. $7.5 \times 9 \mathrm{~mm}$, rounded, 2-lobed; anterior lip $11 \times$ $14 \mathrm{~mm}$, 3-lobed with the median lobe $5 \times 7 \mathrm{~mm}$ and the laterals $7 \times 9 \mathrm{~mm}$. Stamens arising from the mouth of the tube; filaments flat, c. $4 \mathrm{~mm}$ long. Ovary $2.5 \times 1.5 \mathrm{~mm}$; style $5 \mathrm{~mm}$ long. Fruit a spirally twisted capsule, c. $2 \mathrm{~cm}$ long, c. $1.6 \mathrm{~mm}$ wide, glabrous. Seeds compressed, ellipsoid, $0.5 \times 0.12 \mathrm{~mm}$.

Distribution. Malaysia: Sarawak.

Habitat and ecology. On limestone.

Proposed IUCN conservation assessment. Least Concern (LC). The conservation assessment given reflects the fact that although this species is known from few collections they are all from Gunung Mulu National Park which is a World Heritage Site and well protected.

Additional specimens examined. Malaysia. Sarawak: 4th Division, Ulu Medalam District,

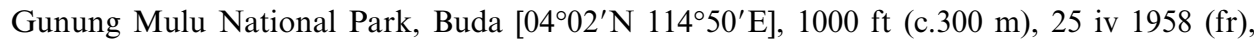
Bruenig 10506 (E, SAR); Gunung Mulu National Park, Below G Buda, N of S Medalam, 200 m, 20 vi 1975 (fr), B.L. Burtt 8333 (E); Gunung Mulu National Park, Benarat cliffs, S flank, facing Melinau, 24 vi 1962 (fl), B.L. Burtt \& P.J.B. Woods 2279 (E); Gunung Mulu National Park, Hidden Valley eastern end, $04^{\circ} 05^{\prime} \mathrm{N} 114^{\circ} 53^{\prime} \mathrm{E}, \mathrm{c} .450$ m, 6 iv 1978 (ster), Argent et al. $908 \mathrm{a}(\mathrm{E}, \mathrm{SAR})$.

This species is rather distinctive amongst the tropical species that have a terminal panicle and whorled leaves by its thick lanate indumentum.

14. Paraboea capitata Ridl., J. Straits Branch Roy. Asiat. Soc. 44 : 67 (1905); Burtt, Notes Roy. Bot. Gard. Edinburgh 41: 426 (1984). - Type: Peninsular Malaysia, Bujong Malacca, C. Curtis 3215 (lecto SING, designated by Burtt (1984: 426); iso SING). Fig. 10. 


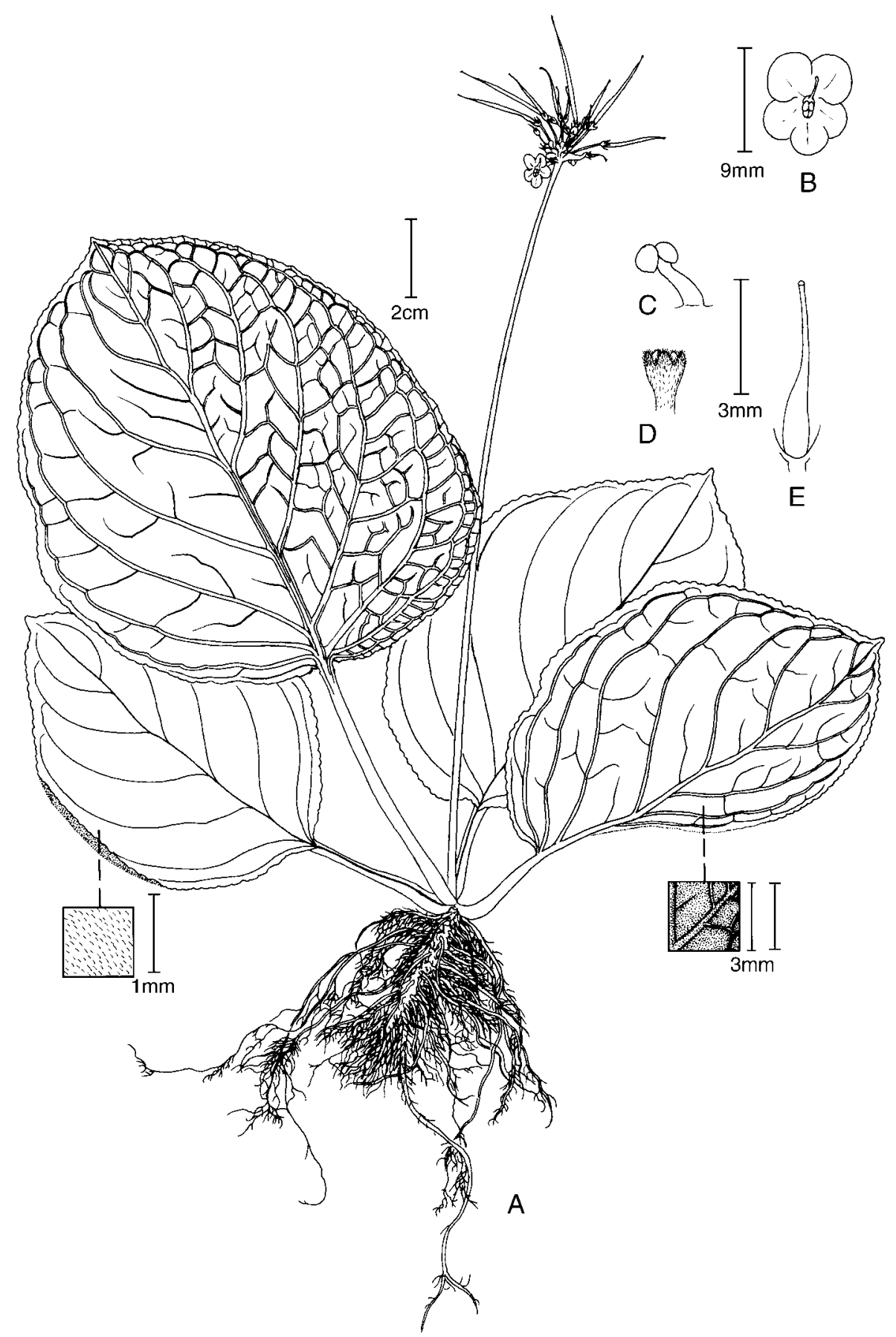

FIG. 10. Paraboea capitata Ridl. A, habit; B, flower; C, stamen; D, calyx; E, pistil. 
Paraboea curtisii Ridl., J. Straits Branch Roy. Asiat. Soc. 44: 70 (1905). - Type: Peninsular Malaysia, Bujong Malacca, cult. Penang, C. Curtis 3214 p.p. (lecto SING, designated by Burtt (1984: 426)).

Paraboea polita Ridl., J. Straits Branch Roy. Asiat. Soc. 44: 69 (1905). - Type:

Peninsular Malaysia, Bujong Malacca, cult. Penang, C. Curtis 3214 p.p. (lecto SING, designated by Burtt (1984: 426)).

\section{4a. Paraboea capitata var. capitata}

Perennial herb, sometimes with rhizome up to $10 \mathrm{~cm}$ long. Leaves opposite, congested in a rosette, petiolate; petiole c. $2-7 \mathrm{~cm}$ long, with a brownish matted indumentum; blades more or less ovate, 5.5-19 $\times 5-11 \mathrm{~cm}, 1-2$ times as long as wide, apex obtuse or very acute, base widely cuneate to shallowly cordate, margin shallowly crenate, upper leaf surface with a dense pubescence, lower leaf surface with a matted indumentum, appearing brownish (yellow, orange, or grey); veins smooth above, raised beneath, lateral veins c.7-10 pairs, tertiary venation reticulate. Inflorescence an axillary cyme, longer than the leaf, c.20 cm long, manyflowered, with a brownish matted indumentum up to the pedicels; primary and secondary branches extremely reduced in length and so flowers congested at top of the peduncle, appearing capitate; peduncle c. $20 \mathrm{~cm}$ long; primary bracts ovate, 5-10 $\times$ 4-6 mm; pedicels c. $5 \mathrm{~mm}$ long. Calyx 5-lobed to the base, lobes narrowly ovate, c. $2 \times 0.5 \mathrm{~mm}$, with a matted indumentum outside, glabrous inside. Corolla white (fide J. Sinclair), c. $20 \mathrm{~mm}$ across, glabrous; tube short, c. $2 \mathrm{~mm}$ long, limb 2-lipped; upper lip $6 \times 13 \mathrm{~mm}$, 2-lobed, lower lip c. $12 \times 20 \mathrm{~mm}$, 3-lobed. Anthers transversely ellipsoid, c. $1.3 \times 3.2 \mathrm{~mm}$, opening in the centre of the anther locules; filaments $2.5 \mathrm{~mm}$ long, inserted at the corolla base. Gynoecium $8 \mathrm{~mm}$ long, minutely pubescent; ovary $0.8 \mathrm{~mm}$ wide; style long and distinct, $0.4 \mathrm{~mm}$ wide; stigma slightly larger than style. Fruit a linear non-twisted capsule, c.1.5-2.5 cm long, held almost horizontal, glabrous, opening by the upper suture (only). Seeds ovoid, $0.6 \times$ $0.25 \mathrm{~mm}$, brown.

Distribution. Peninsular Malaysia (and Thailand?).

Habitat and ecology. On limestone.

Proposed IUCN conservation assessment. Least Concern (LC). This variety has been collected at several sites over a wide area and there are no major threats.

Additional specimens examined. Malaysia. Perak: s.1., 10 ix 1929 (fl), I.H. Burkill 6276 (K); Tambun Limestone, Gunong Ginting $\left[04^{\circ} 35^{\prime} \mathrm{N} 101^{\circ} 08^{\prime} \mathrm{E}\right]$, (ster), S. Ahmad \& M. Sidek SAN581 (C); ibid., $150 \mathrm{~m}, 10$ iii 1971 (lv), S.C. Chin 831 (L); Ipoh, Ayer Hangat [04³6' N $\left.101^{\circ} 05^{\prime} \mathrm{E}\right], 100 \mathrm{~m}, 21$ iv 1962 (fr), B.L. Burtt \& P.J.B. Woods 1687 (E); Ipoh, Gunong Panjang (inside) [04 $\left.36^{\prime} \mathrm{N} 101^{\circ} 08^{\prime} \mathrm{E}\right], 19$ iv 1962 (fr), B.L. Burtt \& P.J.B. Woods 1661 (E); Sunga Ryoh, xi 1880 (fl), H. Kunstler 978 (K); Kamuning, ii 1904 (fl, fr), H.N. Ridley 11894 (K); Sam Poh Tong Temple, 3.5 miles south of Ipoh, 25 x 1958 (fr), J. Sinclair 9870 (E). Penang: [05 $23^{\prime}$ N $\left.100^{\circ} 16^{\prime} \mathrm{E}\right], 1938$ (fl), McNicoll s.n. (E). 
Thailand. Ratchaburi: Thung Kang Yang Hills [1330’ N 99³1'E], 500 m, 6 vii 1963 (lv), K. Larsen 10536 (C).

The status of the single specimen from Thailand should be reinvestigated with better collections.

14b. Paraboea capitata var. oblongifolia Ridl., J. Straits Branch Roy. Asiat. Soc. 44: 68 (1905); Burtt, Notes Roy. Bot. Gard. Edinburgh 41: 426 (1984). - Type: Peninsular Malaysia, Perak, Sungai Siput, xii 1895, C. Curtis 3107 (lecto SING, designated by Burtt (1984: 426); iso K).

This variety can be distinguished from Paraboea capitata var. capitata by the following characters: leaves more or less obovate, gradually narrowed to the base, $11-33 \times 4-10 \mathrm{~cm}, 2-3.5$ times as long as wide, upper leaf surface glabrous or with a sparse minute pubescence.

Distribution. Peninsular Malaysia.

Habitat and ecology. On limestone.

Proposed IUCN conservation assessment. Least Concern (LC). This variety has been collected at several sites over a wide area and there are no major threats.

Additional specimens examined. Malaysia. Perak: Ipoh, Gunong Tempurong [04 $25^{\prime} \mathrm{N}$ $\left.101^{\circ} 08^{\prime} \mathrm{E}\right], 266-566$ m, 13 viii 1959 (fr), B. Allen \& Kadim MK501 (E, L); Gunong Mesah, 13.5 miles S of Ipoh [04 $\left.27^{\prime} \mathrm{N} 101^{\circ} 10^{\prime} \mathrm{E}\right], 20$ iv 1962 (fr), B.L. Burtt \& P.J.B. Woods 1664 (E); Gunong Mesah, 13.5 miles S of Ipoh [04 $\left.27^{\prime} \mathrm{N} 101^{\circ} 06^{\prime} \mathrm{E}\right], 20$ iv 1962 (fl, fr), Cult. in E C4071 (E); 20 iv 1962 (fl), Cult. in E C5134 (E); 20 iv 1962 (fl), Cult. in E C4087 (E); Kuala Dipang [04 $\left.15^{\prime} \mathrm{N} 101^{\circ} \mathrm{E}\right]$, x 1894 (fl, fr), C. Curtis 3107 (K); Gunong Kandu, Kampong Pahang, E from road at K. L. 128, Ipoh 14 milestone, 5 v 1962 (fl), B.L. Burtt \& P.J.B. Woods 1821 (E).

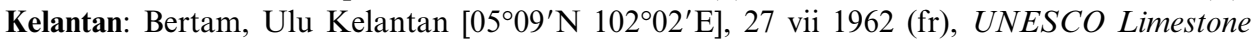
Exp. $9(\mathrm{~K}, \mathrm{~L})$.

If there were no minute hairs on the upper leaf surface in this variety it would have been appropriate to raise it to specific rank as Burtt (1984) implied. B.L. Burtt \& P.J.B. Woods 1664 (E) does have a glabrous upper leaf surface, but most of the other specimens examined do possess a pubescence, though much smaller and sparser than that in Paraboea capitata var. capitata.

15. Paraboea changjiangensis F.W.Xing \& Z.X.Li, Acta Bot. Yunnan. 15(2): 121 (1993). - Type: China, Hainan, Changjiang Xian, Wang-xia, 600 m, 25 vii 1989, Z.X. Li \& F.W. Xing 5134 (holo IBSC).

Perennial caulescent herb; stem 9-40 cm tall, with a dense matted indumentum. Leaves opposite, petiolate; petiole $1-2.5 \mathrm{~cm}$ long, with a matted indumentum; blades thickly membranous, elliptic or oblong, 2-7 $\times 1-3 \mathrm{~cm}$, apex obtuse, base cuneate, margin obtusely dentate, densely pubescent above, with a matted indumentum beneath; veins 
slightly sunken above, raised beneath, lateral veins 5-8 pairs. Inflorescence an axillary cyme, 5-10-flowered, longer than the leaves; peduncle 4-5 cm long, densely pubescent or glabrescent, bracts minute; pedicels 5-10 mm long, pubescent. Calyx 5-lobed to the base, lobes lanceolate, 1.5-2 $\times 0.5-1 \mathrm{~mm}$, pubescent outside. Corolla pale lilac; tube 3-5 mm long, limb 2-lipped; upper lip 2-lobed, lobes ovate, 3-3.5 $\times 2-2.5 \mathrm{~mm}$, apex obtuse, lower lip 3-lobed, central lobe $5 \mathrm{~mm}$ long, apex obtuse, lateral lobes $3 \times$ $2.6 \mathrm{~mm}$. Anthers oblong, 2-2.5 mm long; filaments 1.5-2 $\mathrm{mm}$ long, inserted at the corolla base. Gynoecium $9 \mathrm{~mm}$ long, glabrous; ovary oblong. Fruit a linear twisted capsule, $0.8-1.5 \mathrm{~cm}$ long, $1.5-2 \mathrm{~mm}$ in diameter. Seeds oblong or ovate, $0.4 \mathrm{~mm}$ long.

Distribution. China: Hainan.

Habitat and ecology. On calcareous formations.

Proposed IUCN conservation assessment. Data Deficient (DD). The taxonomic status is not entirely clear so a Data Deficient status is most appropriate.

Additional specimen examined. CHгna. Hainan: Changjiang Xian, Wang-xia, 600 m, 30 ix 1989, F.W. Xing 5142 (IBSC).

Further collections are necessary to see whether this species is really distinct from Paraboea rufescens, a species not otherwise known to occur on Hainan.

16. Paraboea chiangdaoensis Z.R.Xu \& B.L.Burtt, Edinburgh J. Bot. 48 : 3 (1991). - Type: Thailand, Chiangmai, Doi Chiangdao [Ban Chiangdao, $19^{\circ} 30^{\prime} \mathrm{N} 99^{\circ} 00^{\prime} \mathrm{E}$ ], 23 x 1926 (fr), Put 430 (holo K; iso ABD, BM). Fig. 11.

Perennial caulescent herb; stem c. $8 \mathrm{~mm}$ in diameter; internodes 1-3 cm long. Leaves opposite, petiolate; petiole c. $15 \mathrm{~cm}$ long, with broad wings down either side and joining across the node; blades membranous or nearly so, ovate or oblong, 20-25 $\times 8-15 \mathrm{~cm}$, apex obtuse, base more or less truncate and then attenuate into the petiole wings, margin entire, minutely pubescent above, sparsely sublanate beneath, with thicker indumentum when young; veins obscure above, raised beneath, lateral veins 10-12 pairs, tertiary venation indistinctly reticulate. Inflorescence not seen but likely to be subterminal cymose from the bifurcations in the infructescence with 4 cymelets from the apex of the peduncle, with 2 leaflet-like bracts c. $4.5 \times 3 \mathrm{~cm}$; the cymelet in the infructescence $20 \mathrm{~cm}$ long, $15 \mathrm{~cm}$ across, many-flowered. Flowers not seen. Infructescence nearly glabrous, pedicel 1-3 cm long, slender, more or less minutely glandular, with sepal-like bracts; calyx persistent, c. $2 \mathrm{~mm}$ long, 5-lobed to the base, lobes narrow-ovate. Fruit a slender capsule, c. $2.5 \mathrm{~cm}$ long, $1.5 \mathrm{~mm}$ in diameter, glabrous, spirally twisted.

Distribution. Thailand. Known only from the type.

Habitat and ecology. Doi Chiang Dao is a limestone mountain.

Proposed IUCN conservation assessment. Data Deficient (DD). Doi Chiang Dao is in a large national park and the area of limestone within the park is extensive. However, 


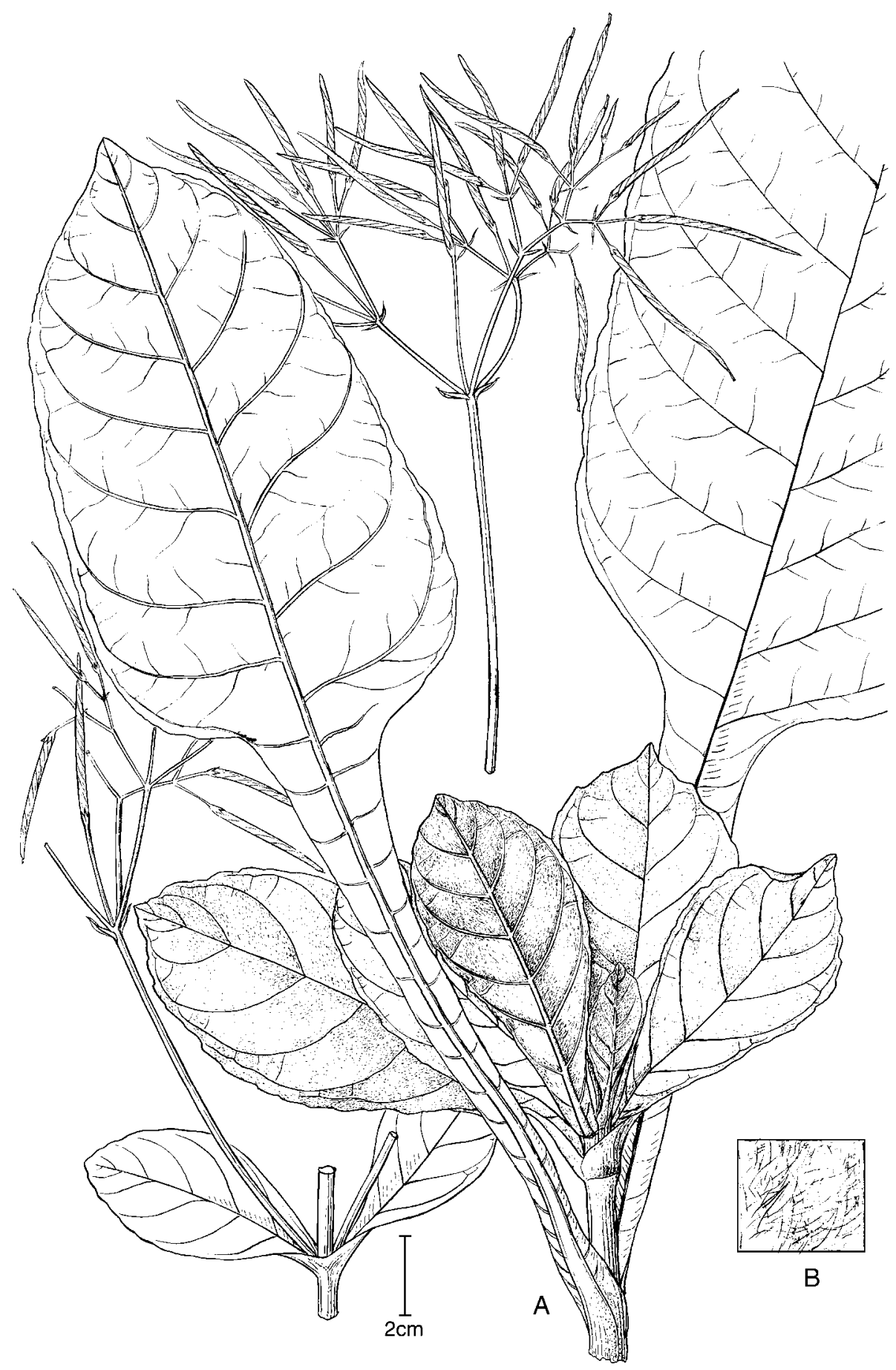

FIg. 11. Paraboea chiangdaoensis Z.R.Xu \& B.L.Burtt. A, habit and detached infructescences; $\mathrm{B}$, indumentum on leaf undersurface. 
the plant has only been collected once and the locality data on the specimen are not specific enough to judge if there are any threats to the particular site where this plant grows. This species was, however, included in Pooma (2005) as threatened in Thailand.

The species is easily distinguished by its large leaves, truncate leaf bases, conspicuously winged petioles, and the pubescence on the upper leaf surface.

17. Paraboea clarkei B.L.Burtt, Kew Bull. 1948: 56 (1948); Burtt, Notes Roy. Bot. Gard. Edinburgh 41: 426 (1984). - Didymocarpus paraboea C.B.Clarke in A.DC. \& C.DC., Monogr. Phan. 5: 100 (1883). - Type: Sarawak, 1857, Lobb s.n. (holo K). Fig. 12.

Perennial herb with a short stem but a distinct rhizome up to $40 \mathrm{~cm}$ long, $1.5 \mathrm{~cm}$ thick, with a brownish matted indumentum throughout the plant. Leaves opposite, congested in the upper part of a stem, but sometimes internodes extending to $1.5 \mathrm{~cm}$ long; petiole short, 1-2 cm long, rarely up to $4 \mathrm{~cm}$ long, with 2 auriculate wings in the lower part, up to $2 \mathrm{~cm}$ long, $1.5 \mathrm{~cm}$ wide, each joined to the one on the opposite leaf at the node, with a yellowish brown matted indumentum; blades elliptic to slightly obovate, $10-25 \times 4.5-14 \mathrm{~cm}$, c.2 times as long as wide, apex obtuse to rounded, base more or less rounded, margin shallowly dentate, upper surface with a dense pubescence, lower surface with a yellowish brown to brown matted indumentum; veins smooth above, prominently raised beneath, lateral veins 812 pairs, tertiary venation reticulate. Inflorescence an axillary cyme, normally longer than the leaves, 15-45 cm long, up to $15 \mathrm{~cm}$ wide when mature, lax, many-flowered, with a yellowish brown matted indumentum throughout except for the flower; peduncle slender, $10-30 \mathrm{~cm}$ long, up to $\mathrm{c} .2 \mathrm{~mm}$ in diameter, two primary bracts narrowly triangular, up to $\mathrm{c} .1 \mathrm{~cm}$ long, $2.5 \mathrm{~mm}$ wide; pedicels $3-5 \mathrm{~mm}$ long, with sepal-like secondary bracts. Flower very small, c. $3.5 \mathrm{~mm}$ long, $5 \mathrm{~mm}$ across. Calyx $<1 \mathrm{~mm}$ long, 5-lobed to the base, lobes ovate or narrowly so, glabrous outside, farinose inside. Corolla white or very pale mauve, c. $5 \mathrm{~mm}$ long, $17 \mathrm{~mm}$ across; tube c. $1.2 \mathrm{~mm}$ long, limb indistinctly 2-lipped; upper lip with 2 lobes, ovate, c. $2 \times$ $2 \mathrm{~mm}$, lower lip with 3 lobes, ovate, c. $2.5 \times 2.2 \mathrm{~mm}$. Anthers yellow, widely ovate or \pm triangular, c. $1.3 \times 1.5 \mathrm{~mm}$, almost erect, opening in the centre of the anther locules, coherent with each other; filaments c. $1.5 \mathrm{~mm}$ long, inserted at the corolla base. Gynoecium c. $5 \mathrm{~mm}$ long; ovary c. $1.5 \times 1.2 \mathrm{~mm}$; style distinct, $3 \times 0.2 \mathrm{~mm}$; stigma not enlarged, all glabrous. Fruit a linear, small, non-twisted capsule, c. $1 \mathrm{~cm}$ long. Seeds flattened, ovoid.

Distribution. Malaysia: Sarawak.

Habitat and ecology. On limestone.

Proposed IUCN conservation assessment. Least Concern (LC). This species has been collected at several sites over a wide area and there are no major threats.

Additional specimens examined. Malaysia. Sarawak: s.1., 11 ii 1914 (fr), Native Collector 2553 (E, K, P, US); ii-vi 1914 (lv), Native Collector 2071 (US); Kuching Division, G. Umbut, Bau, 27 


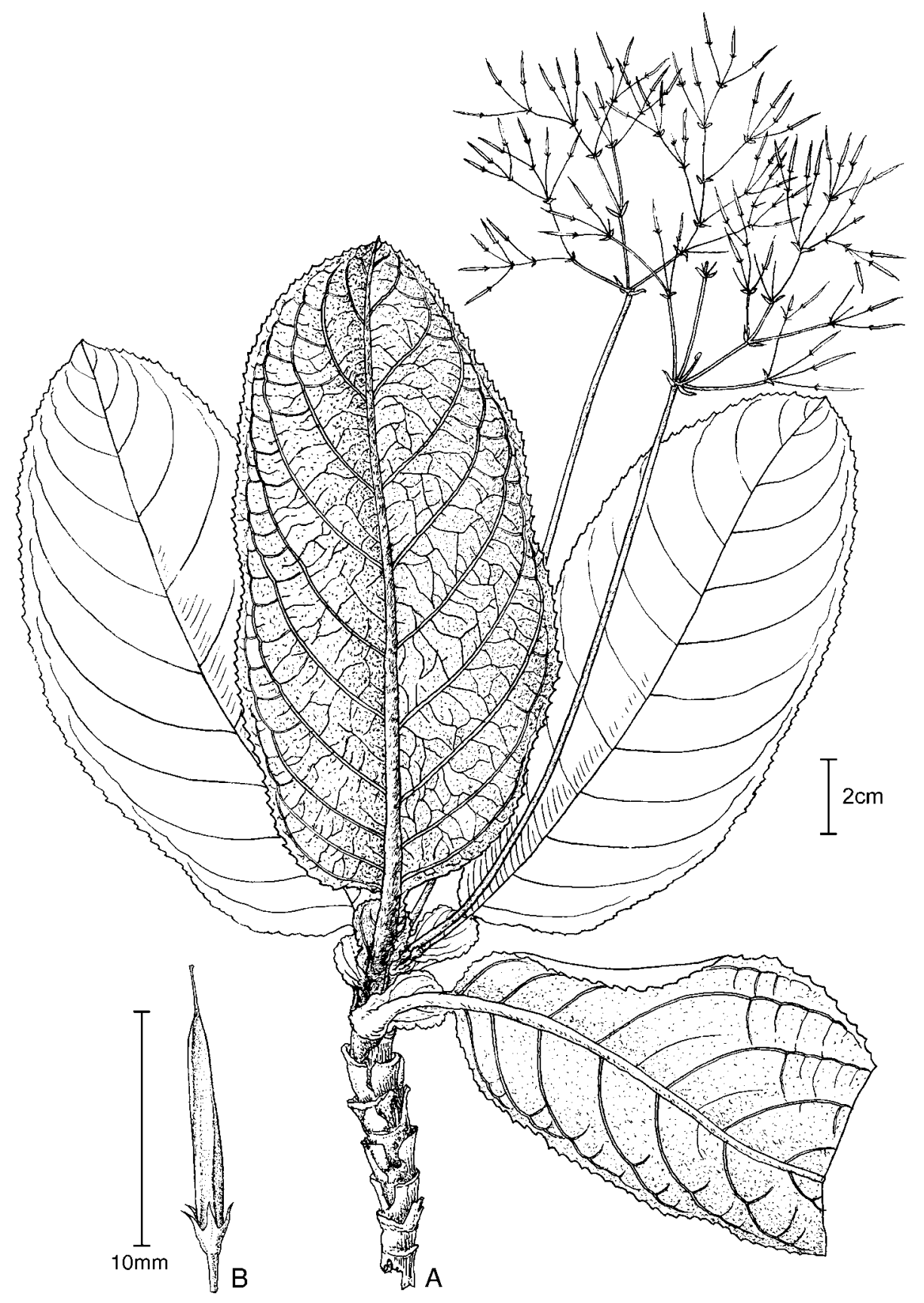

FIg. 12. Paraboea clarkei B.L.Burtt. A, habit; B, fruit. 
iii 2002 (fr), J. Sang et al. SBC2577 (SAR); Gn. Krian, Bau, 21 xi 2001 (fr), D. Malcom et al. SBC1140 (SAR); G. Doya, Bau, 3 x 2002 (fl), S. B. Raymond \& J.J. Stephen SBC3455 (SAR); Gunung Bar, Mambong, Penrissen, Kuching, 19 ii 1993 (fr), L.S. Teck \& Rantai S66017 (SAR); Bau hills, south of Kuching, 10 vii 1963 (fr, fl), F.R. Fosberg 43831 (NY, US); Bukit Gajah, Bau, 9 ii 1999 (fl), Jamree et al. S82073 (SAR); River Braang, 350 m, vi 1890 (fl, fr), G.D. Haviland s.n. (K); 1st Division, Bau [0145'N 11000'E], 70 m, vi 1957 (fl, fr), J.A.R. Anderson 9078 (K, L, SAR); Gunong Tabal, Tai Ton, Bidi Road, Krokong Bau, 22 iii 1999 (fr), Patsipun, Jugah et al. S79999 (SAR); Bukit Daya, Bau, 100-250 m, 20 iv 1957 (fl), J.A.R. Anderson 7753 (SAR); Bau, 13 xi 1955 (fl, fr), W.M.A. Brooke 10771 (L); 1st Division, Bukit Mentawa, limestone hill at Teng Bukap on road to Padawan [01 $\left.{ }^{\circ} 10^{\prime} \mathrm{N} 109^{\circ} 55^{\prime} \mathrm{E}\right], 20 \times 1979$ (fl, fr), B. Bremer \& Bremer 1697 (L, SAR); ibid., at summit of limestone, 1929 (fr, fl), Clemens \& Clemens 20590 (A, K, MO, NY, SAR); Bukit Manok, Padawan, 300 m, 1 iii 1969 (fr), Erwin \& Paul S27413 (SAR); Gunong Braang, Padawan District, 1st Division, 7 v 1975 (fl, fr), B.L. Burtt 8097 (E); Gunong Regu, Padawan District, 8 v 1975 (fl, fr), B.L. Burtt 8104 (E); Bau District, Gunong Tabai, E of Bidi, 18 v 1975 (fr), B.L. Burtt 8160 (E); Bukit Serapat, 13 miles on Kuching-Simanggang road, 25 vii 1967 (fl, fr), B.L. Burtt \& Martin 4748 (E); 1st Division, Bau, Seburan mine, 15 v 1962 (fr), B.L. Burtt \& P.J.B. Woods 1831 (E); Bau District, Bukit Kapor, 22 v 1962 (fr), B.L. Burtt \& P.J.B. Woods 1877 (E); 1st Division, Gunong Staat, 100-300 m, 25 v 1964 (fr), B.L. Burtt \& P.J.B. Woods 1928 (E); 1st Division, 30 km SW of Kuching, Seburan, Bau, 500 m, 14 ix 1958 (fl), $M$. Jacobs 5474 (K, L, SAR, US); Bukit Tebong, Bau District, 1st Division, 100 m, 11 viii 1970 (fr), P.F. Lehmann 394 (E); 1st Division, Jambusan limestone hill, Gunong Batu, 170 m, 8 x 1977 (lv), P.J. Martin S39298 (E, K, KEP, SAR); Bukit Jambusan, Bau, 100 m, 26 ix 1987 (fl, fr), Yii et al. S50339 (SAR); Bidi Caves, 1924 (fl), E. Mjöberg s.n. (UC); Bukit Bidi, 40 m, 26 ix 1987 (fl), Yii et al. S50385 (SAR); Bidi Cave, Ulu Sarawak, xii 1932 (fl, fr), P.W. Richards s.n. (K); 1st Division, Jambusan, near Bau, ix 1905 (fl), H.N. Ridley 72438 (K); 1st Division, Bau, Base of Gunong Taiton, 9 iii 1949 (fl, fr), J. Sinclair 5686 (E); 4th Division, Lobang Rusa [ = Gua Rusa]

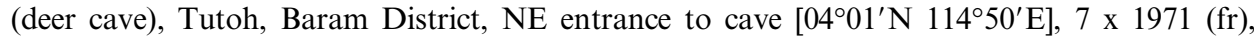
J.A.R. Anderson S31822 (K, SAR); Baram District, Gua Rusa, [0402 $\left.2^{\prime} \mathrm{N} 114^{\circ} 50^{\prime} \mathrm{E}\right], 70 \mathrm{~m}$, (fl, fr), G. Argent \& Kerby 620 (E); 4th Division, Gunung Mulu National Park, Sungei Melinau at Batu Bungar [0402' N 114 $50^{\prime} \mathrm{E}$ ], 29 vi 1962 (fr), B.L. Burtt \& P.J.B. Woods 2337 (E); 4th Division,

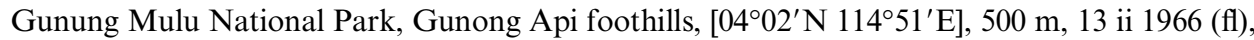
W.L. Chew CWL1108 (K, L); Cult. in E C6030 (E); 4th Division, Gunung Mulu National Park, along Sungai Melinau from S Tutoh to Lobang Bungan, foot of Gunung Mulu, 14 iii 1964 (fl), M. Hotta 14405 (K).

This species is the type species for Paraboea (C.B.Clarke) Ridl. selected by Burtt (1984). It is distinct and characterised by the auriculate petiole and the large axillary cyme that develops subordinate branches below the two primary branches at the top of a peduncle. In Sarawak this species seems to have no close allies. It may be related to Paraboea laxa and P. vulpina from Peninsular Malaysia as these species also develop the subordinate branches in a cyme.

18. Paraboea cochinchinensis (C.B.Clarke) B.L.Burtt, Notes Roy. Bot. Gard. Edinburgh 41: 427 (1984). - Boea cochinchinensis C.B.Clarke in A.DC. \& C.DC., Monogr. Phan. 5: 143 (1883). - Type: Vietnam, Kien Giang, Montagne de Da Bac, ile de Phu Quoc [10 $\left.15^{\prime} \mathrm{N} 104^{\circ} 04^{\prime} \mathrm{E}\right]$, x 1878 (fr), M.C. Godefroy-Lebeuf 859 (holo K; iso P). Fig. 13.

Perennial herb with a very short stem, seemingly rosulate. Leaves opposite, petiolate; petiole $<5 \mathrm{~cm}$ long, with a matted indumentum; blades papery, ovate or elliptic, up 


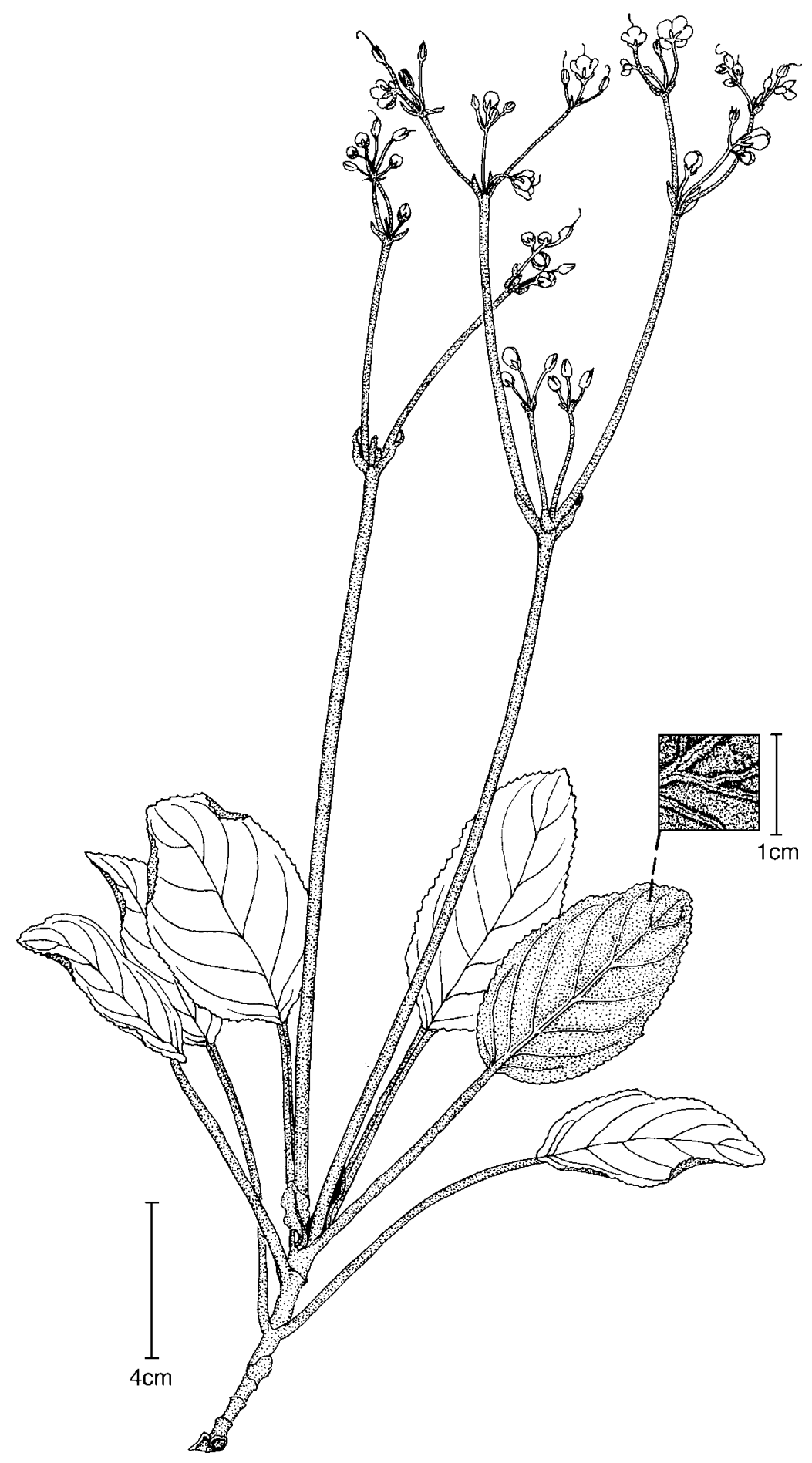

FIG. 13. Paraboea cochinchinensis (C.B.Clarke) B.L.Burtt. 
to $8 \times 3 \mathrm{~cm}$, c. 2 times as long as wide, apex obtuse, base short-angustate, margin entire, upper surface with some arachnoid covering when young and then glabrescent, lower surface with a greyish to brownish matted indumentum; veins smooth above, visible beneath, lateral veins 6-8 pairs, tertiary venation obscure. Flowers not seen. Infructescence subterminal, cymose, from axils below the apical bud, severalflowered, c. $18 \mathrm{~cm}$ long; peduncle slender, c. $9 \mathrm{~cm}$ long, with small ovate bracts, glabrous; pedicels rather slender, $<10 \mathrm{~mm}$ long; calyx persistent, 5-lobed to the base, lobes narrowly ovate, $<3 \mathrm{~mm}$ long, glabrous. Fruit a very slender capsule, c. $2 \mathrm{~cm}$ long, open valves twisted. Seeds not seen.

Distribution. Vietnam. Known only from the type.

Habitat and ecology. Unknown.

Proposed IUCN conservation assessment. Critically Endangered (CR B1ab(ii,iii,v)) see conservation assessment section in introduction.

The type is the only material available for this specific name and the material is very poor with only two too-old cymose infructescences and without any flowers or undehisced capsules. It is difficult, therefore, to make conclusions as to its specific status and relationships with other species. It shares a subterminal inflorescence and an extremely short stem with Paraboea pubicorolla but the very slender peduncle and pedicels of $P$. cochinchinensis distinguishes it from that species. Although we suspect that Paraboea cochinchinensis may be related to $P$. harroviana, $P$. prolixa and $P$. pubicorolla, and could be conspecific with one of these, the poor type material of this species makes any taxonomic certainty impossible and further fieldwork in the type locality is necessary.

19. Paraboea crassifolia (Hemsl.) B.L.Burtt, Notes Roy. Bot. Gard. Edinburgh 41: 427 (1984). - Boea crassifolia Hemsl., J. Linn. Soc., Bot. 26: 233 (1890). - Dorcoceras crassifolium (Hemsl.) Schltr., Bot. Jahrb. 58: 259 (1923). - Type: China, Hupeh [Hubei], Ichang, Nanto [Nanjinguan, $34^{\circ} 47^{\prime} \mathrm{N} 111^{\circ} 18^{\prime} \mathrm{E}$ ] and Mts to northward, x 1887 (fl), Henry 3960 (lecto E, first step designated by Burtt (1984: 427), second step designated here; iso K, US).

Perennial rosulate herb. Leaves sessile, obovate, $3-16 \times 1.5-5 \mathrm{~cm}, 2-3$ times as long as wide, apex rounded, base long-attenuate, margin entire or crenate, upper surface glabrous or with some remaining arachnoid indumentum, lower surface with a greyish or brown matted indumentum; veins smooth above, prominent beneath, lateral veins c.7 pairs, tertiary venation reticulate. Inflorescence axillary, cymose, normally longer than the leaves, 6-12 cm long, 2-5 cm wide, several-flowered, with a matted indumentum or glabrescent; peduncle 3-7 cm long, peduncle bracts and pedicel bracts sepal-like; pedicels c.10-15 mm long. Calyx c. $2 \mathrm{~mm}$ long, 5-lobed, lobes narrow-oblong or ovate, mostly glabrous. Corolla violet with yellow patches, c. $1.2 \mathrm{~cm}$ long, $1 \mathrm{~cm}$ across when fully open; tube c. $7 \mathrm{~mm}$ long, limb 2-lipped; upper 
lip c. $4 \mathrm{~mm}$ long, 2-lobed, lobes wide-ovate, c.3.5 $\times 5 \mathrm{~mm}$, lower lip c. $6 \mathrm{~mm}$ long, 3-lobed, lateral lobes wide-ovate, c. $5 \times 6 \mathrm{~mm}$, middle lobe rounded, c. $3.5 \times 4 \mathrm{~mm}$. Anthers transversely ellipsoid, c. $1 \times 3 \mathrm{~mm}$, coherent with each other, opening at each end of the anther; filaments inserted at c. $4 \mathrm{~mm}$ from the corolla base with a free part c.3-4 mm long, strongly swelling near the base to form a knee. Gynoecium c. $8 \mathrm{~mm}$ long, $1.2 \mathrm{~mm}$ wide at the ovary base; stigma slightly larger than style. Fruit a linear capsule, c. $2 \mathrm{~cm}$ long, glabrous, spirally twisted.

Distribution. Southwest and central China.

Habitat and ecology. On limestone.

Proposed IUCN conservation assessment. Least Concern (LC). This species has been collected at several sites over a wide area and there are no major threats.

Additional specimens examined. China. 1900-1920 (lv), J. Cavalerie 3145 (P); 2700 m, vii 1921 (fl), R.P. Maire s.n. (P); 750 m, (fl), R.P. Maire s.n. (P). Hubei: iii 1889 (fl), A. Henry 6363 (K,

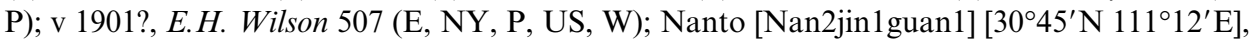
(fl), E.H. Wilson 876 (E). Sichuan: Changjiang, Wushan Gorge [31 $\left.06^{\prime} \mathrm{N} 109^{\circ} 51^{\prime} \mathrm{E}\right]$, (fl), E. Faber 797 (K, W); Wushan Gorge, (fl), E.H. Wilson 1903 (E). Yunnan: 24 vii 1908 (fl), F.

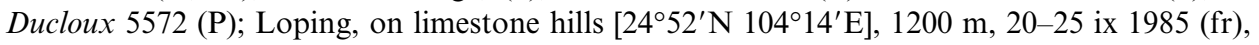
Z.R. Xu LM4988 (E, SYS).

See discussion under Paraboea neurophylla.

20. Paraboea detergibilis (C.B.Clarke) B.L.Burtt, Notes Roy. Bot. Gard. Edinburgh 24: 46 (1962); Burtt, Notes Roy. Bot. Gard. Edinburgh 41: 427 (1984). - Didymocarpus detergibilis C.B.Clarke in A.DC. \& C.DC., Monogr. Phan. 5: 107 (1883). - Type: [Indonesia], Ins. Billiton [as Belitong Island, $03^{\circ} 00^{\prime} \mathrm{S}$ $107^{\circ} 30^{\prime} \mathrm{E}$ ], 1876 (fl, fr), Riedel s.n. (holo FI; iso E).

Perennial caulescent or rosette-like herb; stem (rhizome?) reaching to more than $20 \mathrm{~cm}$ long (most probably trailing on the ground) with roots at the nodes, with a dense and thick layer of whitish matted indumentum. Leaves oppositely congested, rosette-like, or quite remotely cauline with internodes up to $6 \mathrm{~cm}$ long, petiolate; petiole c. $2-8 \mathrm{~cm}$ long, with the same indumentum as that on the stem; blades ovate or narrowly so, $5-11 \times 2.5-5.5 \mathrm{~cm}, \mathrm{c} .1 .5-3$ times as long as wide, apex obtuse, base widely cuneate or rounded, margin entire, upper surface arachnoid when young and then glabrescent when mature, lower surface with a whitish matted indumentum especially on the veins forming a beautiful reticulate appearance; veins smooth above, raised beneath, lateral veins c.8-10 pairs. Inflorescences axillary, cymose, often more than one in an axil, normally longer than the leaf, 10-20 cm long, fewflowered, with some matted indumentum when young and later glabrescent; peduncles $8-18 \mathrm{~cm}$ long, with sepal-like bracts, glabrescent; pedicels 5-12 $\mathrm{mm}$ long, glabrous. Calyx lobes narrowly ovate, c. $1.5 \times 0.7 \mathrm{~mm}$, glabrous outside, more or less minutely sessile-glandular inside. Corolla pale purple or pale blue purple, 5-6 mm across, $10 \mathrm{~mm}$ long; tube distinct, c. $4.5 \mathrm{~mm}$ long, limb 2-lipped; upper lip much 
smaller, 2-lobed, lobes ovate, $2 \times 2.5 \mathrm{~mm}$, lower lip 3-lobed, middle lobe ovate, c.3.5 $\times$ $3.5 \mathrm{~mm}$, lateral lobes c. $3.5 \times 4 \mathrm{~mm}$. Anthers transversely ellipsoid, c. $1.5 \times 2 \mathrm{~mm}$, opening in the centre of the anther locules, coherent with each other, dorsifixed; filaments $3 \mathrm{~mm}$ long, inserted at the extreme base of the corolla, curved resulting in the anthers turning towards the gynoecium. Gynoecium c. $3.5 \mathrm{~mm}$ long; ovary $1.2 \mathrm{~mm}$ wide; style short or indistinct, c. $0.3 \mathrm{~mm}$ wide; stigma slightly larger. Fruit a linear nontwisted capsule, c. $2.5 \mathrm{~cm}$ long, $1.2 \mathrm{~mm}$ wide, glabrous. Seeds ellipsoid, $0.5 \times 0.15 \mathrm{~mm}$.

Distribution. Indonesia (Billiton, Bangka, west Sumatra) and Malaysia (Sarawak).

Habitat and ecology. Reported from limestone.

Proposed IUCN conservation assessment. Least Concern (LC). This species has been collected at several sites over a wide area and there are no major threats.

Additional specimens examined. s.l., (fl), W. Hutton s.n. (K). Indonesia. Bangka: G. Mangkol Pangkat Pinang [02 $\left.50^{\prime} \mathrm{S} 106^{\circ} 00^{\prime} \mathrm{E}\right], 200-397 \mathrm{~m}, 28$ xi 1917 (fl, fr), Buennemeyer 2114 (L); G. Mangkol, 50 m, 9 xii 1949 (fl, fr), A.J.G.H. Kostermans \& Anta 619 (E, K, L); ibid., 23 x 1949 (fl), A.J.G.H. Kostermans \& Anta 1246 (K, L). Sumatra (province unknown): Mont Gangir, (fr), Teysmann s.n. (L).

Malaysia. Sarawak: Path to G. Gaharu, (Endau Jelutong) between Ulu Sg. Sabal Tapang \& Aping, 70th Mile, Serian/Simanggang Rd, 400 m, 10 iv 1974 (fl), Ilias \& Azagari S35610 (SAR).

It is not difficult to recognise this species with its reticulate venation and a whitish (silvery) matted indumentum that adds to its remarkable appearance. Its affinities within the genus are obscure.

21. Paraboea dictyoneura (Hance) B.L.Burtt, Notes Roy. Bot. Gard. Edinburgh 41: 427 (1984) [but excluding Boea harroviana Craib and Boea treubii sensu Pellegrin in Lecomte, Fl. Indo-Chine 4: 544 (1930)]. - Boea dictyoneura Hance, J. Bot. 21: 169 (1883). - Type: China, Canton, Lien-chau, v 1880 (fl), Henry 21741 in herb. Hance (holo BM; iso K). [The collector confused the type locality by spelling the name of the provincial capital city (Canton = Guangzhou) to represent the province of Guangdong. Lien-chau (= Lianxian) is not the suburban area of the provincial capital, but is rather a county in the northern part of the province, more than $200 \mathrm{~km}$ from the provincial capital. The area has typical limestone landscapes.] Fig. 14.

Boea hancei C.B.Clarke in A.DC. \& C.DC., Monogr. Phan. 5: 144 (1883). - Type: China, Canton, Lien-chau, v 1880 (fl), Henry 21741 in herb. Hance (holo K; iso $\mathrm{BM})$. Note this is the same type collection as Boea dictyoneura.

Perennial rosulate herb, sometimes with a short rhizome from rock crevices, c. $10 \mathrm{~cm}$ long, $7 \mathrm{~mm}$ in diameter. Leaves sessile or with a short petiole up to $3 \mathrm{~cm}$ long; blades narrowly obovate-elliptic, c. $7-15 \times 2-4.5 \mathrm{~cm}, 2-3.5$ times as long as wide, apex acute or obtuse, base long-attenuate to the rosette and slightly swelling at the very base, margin more or less serrulate, upper surface with some arachnoid 


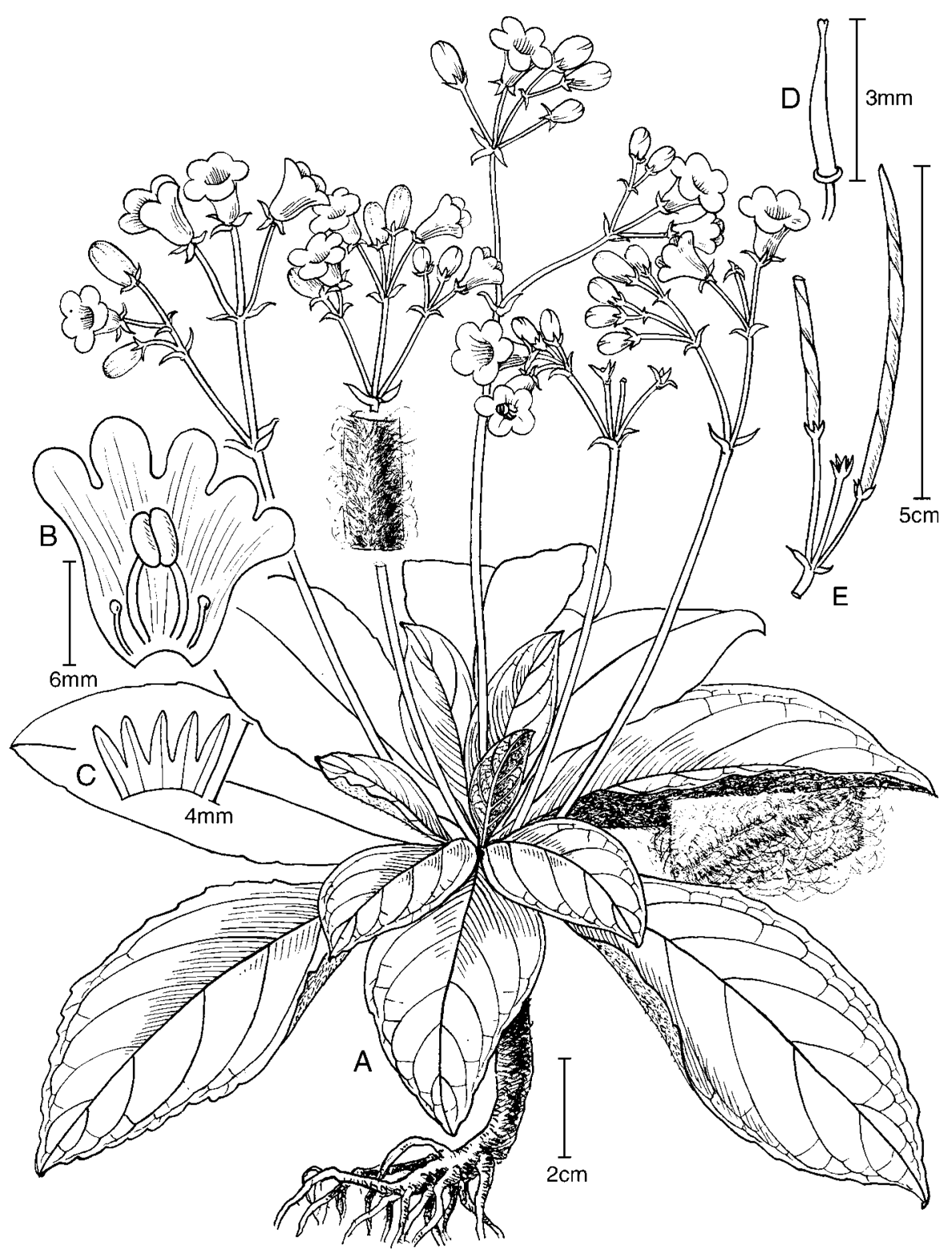

FIg. 14. Paraboea dictyoneura (Hance) B.L.Burtt. A, habit; B, corolla opened out; C, calyx opened out; D, pistil; E, fruits.

covering when young and then glabrescent, lower surface with a greyish matted indumentum; veins smooth above, raised beneath, lateral veins 6-10 pairs, tertiary venation conspicuously reticulate on the lower leaf surface. Inflorescence axillary, cymose, normally longer than the leaves, $10-15 \times 4-5 \mathrm{~cm}$, at first covered by 
the same indumentum as that on the lower leaf surface, later glabrescent; peduncle $8-12 \mathrm{~cm}$ long with bracts narrowly ovate, c.5 $\mathrm{mm}$ long; pedicels 5-15 mm long, with bracts narrowly ovate, c. $2 \mathrm{~mm}$ long. Calyx c. $6 \mathrm{~mm}$ long, 5-lobed, lobes narrowly ovate, c. $5 \times 1 \mathrm{~mm}$, with a matted indumentum outside and glabrous inside. Corolla purple, c. $1.3 \mathrm{~cm}$ long, $1.3 \mathrm{~cm}$ across when fully open; tube c. $6 \mathrm{~mm}$ long, swelling where the filaments are inserted, limb 2-lipped; upper lip 2-lobed, lobes widely ovate, c. $4.5 \times 5 \mathrm{~mm}$, lower lip c. $8 \mathrm{~mm}$ long, 3-lobed, the middle lobe similar in shape and size to the lateral lobes, wide-ovate, c. $6 \times$ $7.5 \mathrm{~mm}$. Anthers transversely ellipsoid, c. $2 \times 3.5 \mathrm{~mm}$, apex pointing towards the gynoecium, basifixed, coherent with each other; filaments inserted at the corolla base in line with the connections between the middle lobe and the two lateral lobes of the lower lip, attached at c. $1 \mathrm{~mm}$ from the corolla base with a free part c.7 mm long, glabrous; two distinct staminodes, c. $4.5 \mathrm{~mm}$ long, filament-like, inserted at the corolla base in line with the connection between the lower lip and the upper lip, and one indistinct staminode about half the length of the other two and much thinner, inserted at the corolla base in line with the connection between the two upper lobes. Gynoecium glabrous, c.10 mm long, $1 \mathrm{~mm}$ wide at the ovary base; stigma not much enlarged. Fruit a linear capsule, c.3.5-6 cm long, $2 \mathrm{~mm}$ wide, glabrous, slightly twisted. Seeds narrowly ellipsoid, c. $1 \times 0.3 \mathrm{~mm}$.

Distribution. Northern Vietnam and southern China.

Habitat and ecology. On limestone.

Proposed IUCN conservation assessment. Least Concern (LC). This species has been collected at several sites over a wide area and there are no major threats. This species was, however, included in Pooma (2005) as threatened in Thailand.

Additional specimens examined. CHINA. Guangdong: Ruyuan County $\left[24^{\circ} 50^{\prime} \mathrm{N} 113^{\circ} 20^{\prime} \mathrm{E}\right], 14 \mathrm{v}$ 1933 (fr), X.P. Gao 52605 (IBSC, xero. E); Ruyuan [24 $50^{\prime} \mathrm{N} 113^{\circ} 20^{\prime} \mathrm{E}$ ], 16 iv 1934 (fl, fr), S.B. Guo 80229 (IBSC, xero. E); Yunfou [Yun2fu2] [22 $58^{\prime} \mathrm{N} 110^{\circ} 02^{\prime} \mathrm{E}$ ], 10 iii 1937 (fl), Z. Huang 40818 (IBSC); N Guangdong, 1940 (fl), T.R. Liu 104 (IBSC); Lian County [Lian2xian4] [24 50'N 112 $25^{\prime}$ E], 300 m, 20 vi 1984 (fr), Nanling Survey Exp. 121 (IBSC); Lu Tseh Tsung, Yun Fou District [Yun2fu2], 300 m, 24 i 1928 (fl), C.T. Wuang $496(\mathrm{E})$.

Vietnam. Thanh Hoa: Kien Khe, Mt. Ba Lam $\left[20^{\circ} 40^{\prime} \mathrm{N} 105^{\circ} 40^{\prime} \mathrm{E}\right], 12$ iii 1884 (fl, fr), R.P. Bon $2501(\mathrm{P})$.

Burtt (1984) reduced Boea harroviana Craib to synonymy of this species, thereby adding Thailand to the distribution of Paraboea dictyoneura. However, Boea harroviana Craib has a subterminal cymose inflorescence with a distinct stem, while Paraboea dictyoneura possesses a true axillary cyme from basal leaves. They are two good species.

The type material only has a young inflorescence with flower buds. However, Liu Rutang 104 (IBSC), with mature flowers, and Nanling Survey Exp. 121 (IBSC), with mature fruits, have also been collected from the type locality. 
The flower of this species is similar to those of Paraboea martinii and related species. The corolla tube is long and unequal, swelling at the base on the ventral side, and the limb is indistinctly 2-lipped with 5 lobes of almost similar size and shape. The gynoecium is linear, without a clear distinguishable boundary between the ovary and the style. Based on the morphology of the inflorescence and the habit it is possibly related to Paraboea crassifolia and P. neurophylla.

22. Paraboea divaricata (Rid1.) B.L.Burtt, Notes Roy. Bot. Gard. Edinburgh 41: 428 (1984). - Boea divaricata Ridl., J. Straits Branch Roy. Asiat. Soc. 44: 75 (1905).

- Type: Peninsular Malaysia, Langkawi, Ayer Hangat, xi 1901 (fr), Curtis 3683 (lecto SING, designated by Burtt (1984: 428); iso K).

Perennial rosulate herb with a short stem c. $30 \mathrm{~cm}$ tall. Leaves in crowded whorls of $3-4$, sessile, elliptic or nearly so, $15-25 \times 6-9 \mathrm{~cm}, 2-3$ times as long as wide, apex obtuse, base long- or short-attenuate, margin serrate or serrulate, upper surface pubescent, lower surface with a sparse brown matted indumentum; veins obscure above, raised beneath, lateral veins c.10-16 pairs, tertiary venation reticulate. Inflorescence of subterminal cymes, c. $60 \mathrm{~cm}$ long, $20 \mathrm{~cm}$ wide, with many flowers, with a sparse brown or greyish matted indumentum throughout except on the corolla and inside when young, later \pm glabrescent; peduncle $\mathrm{c} .45 \mathrm{~cm}$ long, quite robust, $4 \mathrm{~mm}$ in diameter, with bracts narrowly ovate, c. $1 \mathrm{~cm}$ long; pedicels 2-5 mm long with sepal-like bracts. Calyx c.1 mm long, 5-lobed to the base, lobes narrowly ovate. Corolla c.1 cm across when open; tube c.1.5 mm long, limb 2-lipped; upper lip wide-ovate, c. $2.5 \times 3 \mathrm{~mm}$, 2-lobed, lower lip c.3.5 $\times 5 \mathrm{~mm}$, 3-lobed, middle lobe slightly longer than the lateral lobes, c. $1.5 \times 1.8 \mathrm{~mm}$. Anthers ellipsoid, c. $1 \times 2 \mathrm{~mm}$, coherent with each other, dehiscing longitudinally, apex pointing upward, dorsifixed; filaments inserted nearly at the throat of the corolla with a free part c. $1.5 \mathrm{~mm}$ long, curved. Gynoecium c.5 mm long; ovary clearly distinguishable from the style; stigma not larger than style. Fruit a linear, very delicate, capsule, c.1-2 cm long, glabrous, spirally twisted. Seeds ellipsoid, c. $0.5 \times$ $0.2 \mathrm{~mm}$, glabrous.

Distribution. Peninsular Malaysia: Langkawi.

Habitat and ecology. On limestone.

Proposed IUCN conservation assessment. Vulnerable (VU D2). This species is currently only known from three collections from Langkawi. Although Ayer Hangat is a forest reserve the limestone areas of Langkawi are not fully protected and it should be considered Vulnerable.

Additional specimens examined. Malaysia. Kedah: Pulau Langkawi, N end [06 $\left.28^{\prime} \mathrm{N} 99^{\circ} 50^{\prime} \mathrm{E}\right]$, 30 iv 1962 (lv), B.L. Burtt \& P.J.B. Woods 1775 (E); Batu Puteh ['white rock'], Langkawi [06 $\left.20^{\prime} \mathrm{N} 99^{\circ} 48^{\prime} \mathrm{E}\right], 20$ xi 1941 (fr), E.J.H. Corner s.n. (SING); Ayer Hangat, Langkawi [06 $\left.25^{\prime} \mathrm{N} 99^{\circ} 49^{\prime} \mathrm{E}\right]$, xi 1901 (fl, fr), Cult. in K [from Curtis 3683] (K). 
Burtt \& Wood's collection (sterile, E) is from Langkawi, but Corner's collection is 'from Langkawi; near Ayer Hangat, but not flowering, and then flowering in the Bot. Gard. Penang in Oct.-Nov'. The latter specimen bears flowers and fruits.

Although this species has leaves in whorls of 3-4 and Paraboea patens opposite leaves, they are likely to be related as they share a similar inflorescence structure and similar flowers and capsules.

23. Paraboea effusa B.L.Burtt, Bot. J. Linn. Soc. 85: 28 (1982); Burtt, Notes Roy. Bot. Gard. Edinburgh 41: 428 (1984). - Type: Sarawak, Gunung Mulu National

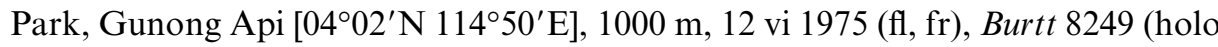
E; iso E, SAR). Fig. 15.

Perennial caulescent subshrub; stem woody, up to $1 \mathrm{~m}$ tall, $1 \mathrm{~cm}$ in diameter, internodes short or long, 1-10 cm, with some brown matted indumentum when young and then glabrescent. Leaves opposite or in whorls of 3, short-petiolate; petiole 0.5 $2 \mathrm{~cm}$ long; blades narrow-elliptic, more or less obovate, 10-30 $\times 3.5-7 \mathrm{~cm}, \mathrm{c} .3-4$ times as long as wide, apex acute or short-acuminate, base attenuate, margin entire, upper surface arachnoid and glabrescent, lower surface with a yellowish-white to light brown matted indumentum; veins smooth above, raised beneath, lateral veins 16-25 pairs, tertiary venation invisible. Inflorescence terminal paniculate, quite lax, with some arachnoid covering and matted pubescent but often glabrescent, flowers glabrous; flowering stem $25-75 \mathrm{~cm}$ long, the lowest internodes $2.5-20 \mathrm{~cm}$ long; floral leaves somewhat smaller than the vegetative leaves; 3-4 cymes from each node; cymes from lower axils up to $15 \mathrm{~cm}$ long, many-flowered; peduncle $6-12 \mathrm{~cm}$ long, peduncle bracts narrow-ovate, 5-6 mm long, pedicel bracts sepal-like; pedicel c.5-10 mm long. Calyx c. $2 \mathrm{~mm}$ long, 5-lobed, lobes narrow-ovate. Corolla lilac, light purple or bright blue, glabrous, c. $7 \mathrm{~mm}$ long, $10 \mathrm{~mm}$ across when fully open; tube $2.5 \mathrm{~mm}$ long, limb 2lipped; posterior lip 2-lobed, lobes \pm rounded, c. $5 \times 5 \mathrm{~mm}$; anterior lip c. $10 \mathrm{~mm}$ long, 3-lobed, middle lobe longer than the lateral lobes, \pm rounded, lateral lobes similar in shape, c. $4 \times 6.5 \mathrm{~mm}$. Anthers yellow, transversely ellipsoid, c. $2 \times 3.5 \mathrm{~mm}$, coherent with each other at the apex and the base, opening in the centre of the anther locules, apex turned towards the gynoecium, dorsifixed; filaments inserted at c. $3 \mathrm{~mm}$ from the corolla base with a free part c. $4 \mathrm{~mm}$ long. Ovary ovoid, distinct from the style, c. $1.5 \times$ $1 \mathrm{~mm}$; style 2-5 mm long, narrower; stigma capitate, not much larger than style. Fruit a linear or narrowly oblong, spirally twisted capsule, $1.5-2.5 \mathrm{~cm}$ long, $1.2 \mathrm{~mm}$ wide, glabrous. Seeds narrowly ellipsoid, c. $8 \times 2 \mathrm{~mm}$.

Distribution. Malaysia: Sarawak.

Habitat and ecology. On limestone.

Proposed IUCN conservation assessment. Least Concern (LC). The conservation assessment given reflects the fact that although this species is known from one small region that region is Gunung Mulu National Park which is a World Heritage Site and well protected. 


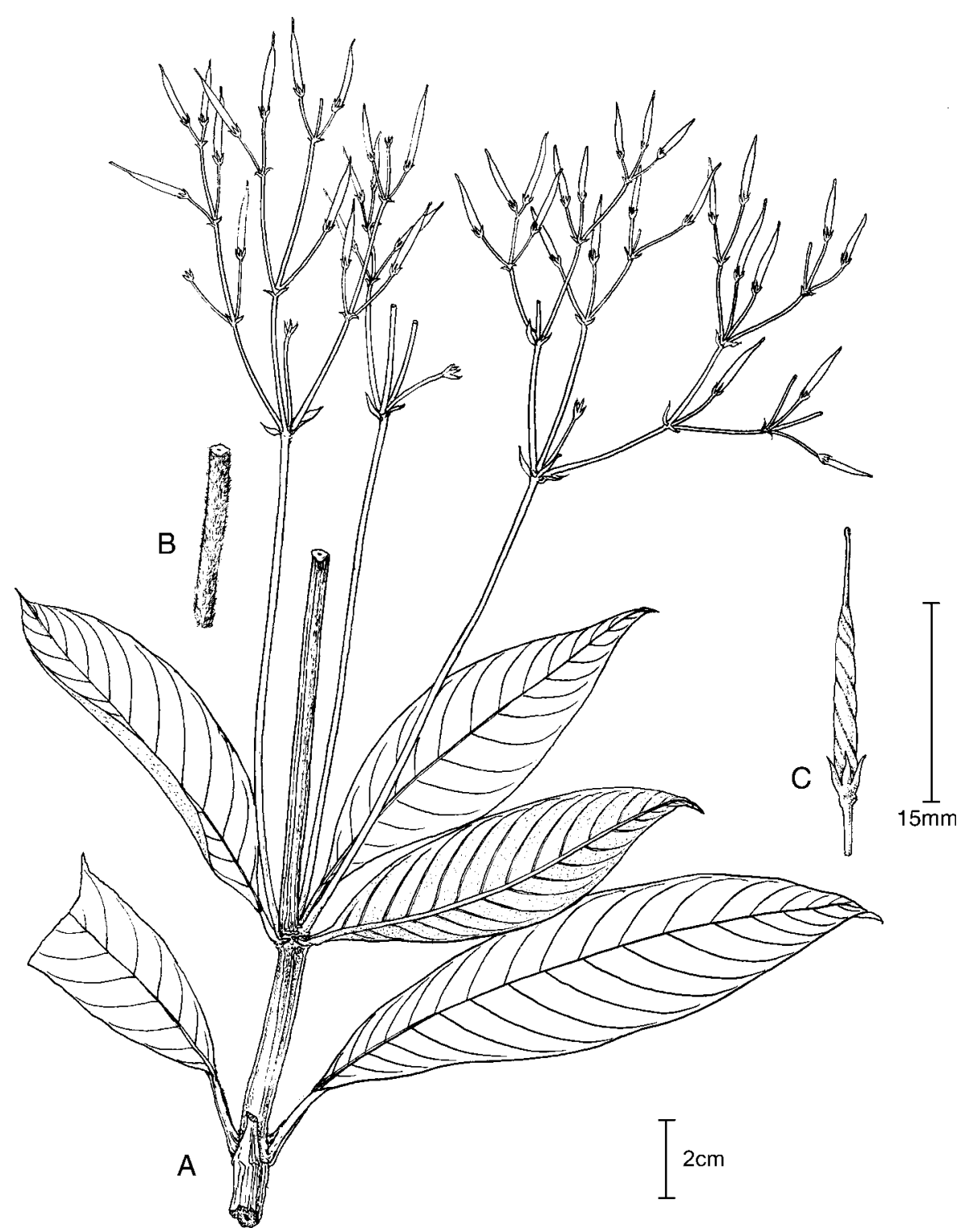

FIG. 15. Paraboea effusa B.L.Burtt. A, habit; B, section of peduncle; C, fruit.

Additional specimens examined. Malaysia. Sarawak: 4th Division: Baram District, Gunung

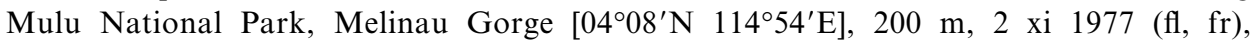
G. Argent et al. 651 (E, KEP); ibid., 26 vi 1962 (fr), B.L. Burtt \& P.J.B. Woods 2309 (E); Limestone hills opposite Long Bala, Sungai Melinau, 200 m, 26 iii 1990 (fl), P.C. Yii \& A. Talib S58809 (SAR); Gunung Mulu National Park, Below G. Buda, N of S. Medalam $\left[04^{\circ} 02^{\prime} \mathrm{N} 114^{\circ} 50^{\prime} \mathrm{E}\right], 350 \mathrm{~m}, 21$ vi 1975 (fr), B.L. Burtt 8338 (E); Gunung Mulu National

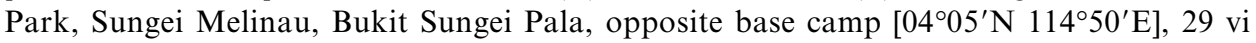


1962 (fr), B.L. Burtt \& P.J.B. Woods 2347 (E); Gunung Mulu National Park, S. Melinau, Batu Bungar, (lv), B.L. Burtt \& P.J.B. Woods 2384 (E); Gunung Mulu National Park, G. Buda, 1000 m, 17 x 1977 (fl, fr), P. Chai S39903 (A, KEP, MO, SAR); Gunung Mulu

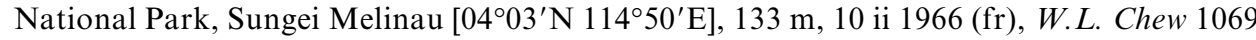
(A, L); Gunung Mulu National Park, 180 m, 6 x 2001 (fl, fr), Julaihi Lai S86866 (SAR); Gunung Mulu National Park, Gunung Api, 890-1170 m, 29 iii 1990 (fr), P. C. Yii \& A. Talib S58873 (SAR); near Gunung Mulu National Park, summit of limestone hills opposite

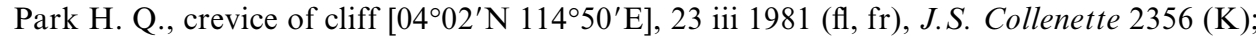

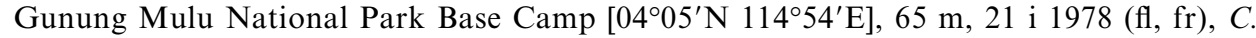
Hansen 101 (E, SAR); Gunung Mulu National Park, NW of Sungai Lansat, $04^{\circ} 01^{\prime} \mathrm{N}$ $114^{\circ} 49^{\prime} \mathrm{E}, 15$ xi 1977, Argent et al. 738 (E, SAR); Miri Division, Gunung Mulu National Park, 7 v 1985 (fl), Abg. Mohtar et al. S49645 (E); Miri Division, Sungei Tutoh, Melana Prot. For., 035' N 114 51'E, 600 m, 14 iv 1997 (fr), R.M.A.P. Haegens, N. Klazenga, L.C.J. Julaihi, Rantai et al. 337 (SAR).

Among the tropical species that have a terminal panicle and whorled leaves this species, together with Paraboea meiophylla and P. apiensis, is characterised by the glabrous calyx. The other species in this group have a matted indumentum on the calyx. Paraboea effusa can be distinguished from Paraboea meiophylla by the much larger leaves and from $P$. apiensis by the generally cuneate leaf base (see also discussion under that species).

24. Paraboea elegans (Ridl.) B.L.Burtt, Notes Roy. Bot. Gard. Edinburgh 41: 428 (1984). - Boea elegans Ridl., J. Linn. Soc., Bot. 32: 522 (1896). - Type: Kedah,

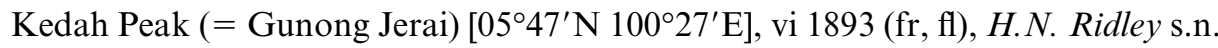
(lecto SING, designated by Burtt (1984: 428)). Fig. 16.

Paraboea obovata Ridl., J. Straits Branch Roy. Asiatic Soc. 44: 71 (1905). - Type: Langkawi Isl., Gunong Chinchang (= Machinchang), ix 1890, Curtis s.n. (holo SING).

Perennial caulescent herb; stem up to $15 \mathrm{~cm}$ long, triangular when young, sometimes with a rhizome up to $15 \mathrm{~cm}$ long, with a whitish matted indumentum; internodes 5 $40 \mathrm{~mm}$ long and elongating when flowering. Leaves in whorls of 3, sessile or petiolate (with petiole up to $6 \mathrm{~cm}$ long); blade narrow-elliptic, ovate or obovate, 4-9 $\times$ 1.5-4 cm, c.1.5-4 times as long as wide, apex acute or obtuse, base long-attenuate and joining across the node or widely cuneate but still with very narrow wings along the petiole to the node, margin entire, upper surface with some arachnoid covering, lower surface with a yellowish white matted indumentum; veins visible above, slightly raised beneath, lateral veins c.7 pairs, tertiary venation invisible. Inflorescences $1-4$, subterminal, cymose, up to $30 \mathrm{~cm}$ long when fruiting, lax, with many flowers, with glandular pubescence on the peduncles, bracts, pedicels and calyces; peduncle stout, up to $23 \mathrm{~cm}$ long, with 2 narrow-ovate bracts c. $2 \mathrm{~mm}$ long; pedicels 10-20 mm long. Calyx c. $2 \mathrm{~mm}$ long, 5-lobed to the base, lobes ovate or narrowly so, c. $2.3 \times 1 \mathrm{~mm}$. Corolla very pale lilac in open flower (in bud deeper lilac), with a short tube and a longer limb, c. $1.7 \mathrm{~cm}$ across when fully open, limb not remarkably 2-lipped with 5 lobes of similar size and shape, lobes widely ovate, c. $7 \times 10 \mathrm{~mm}$. 


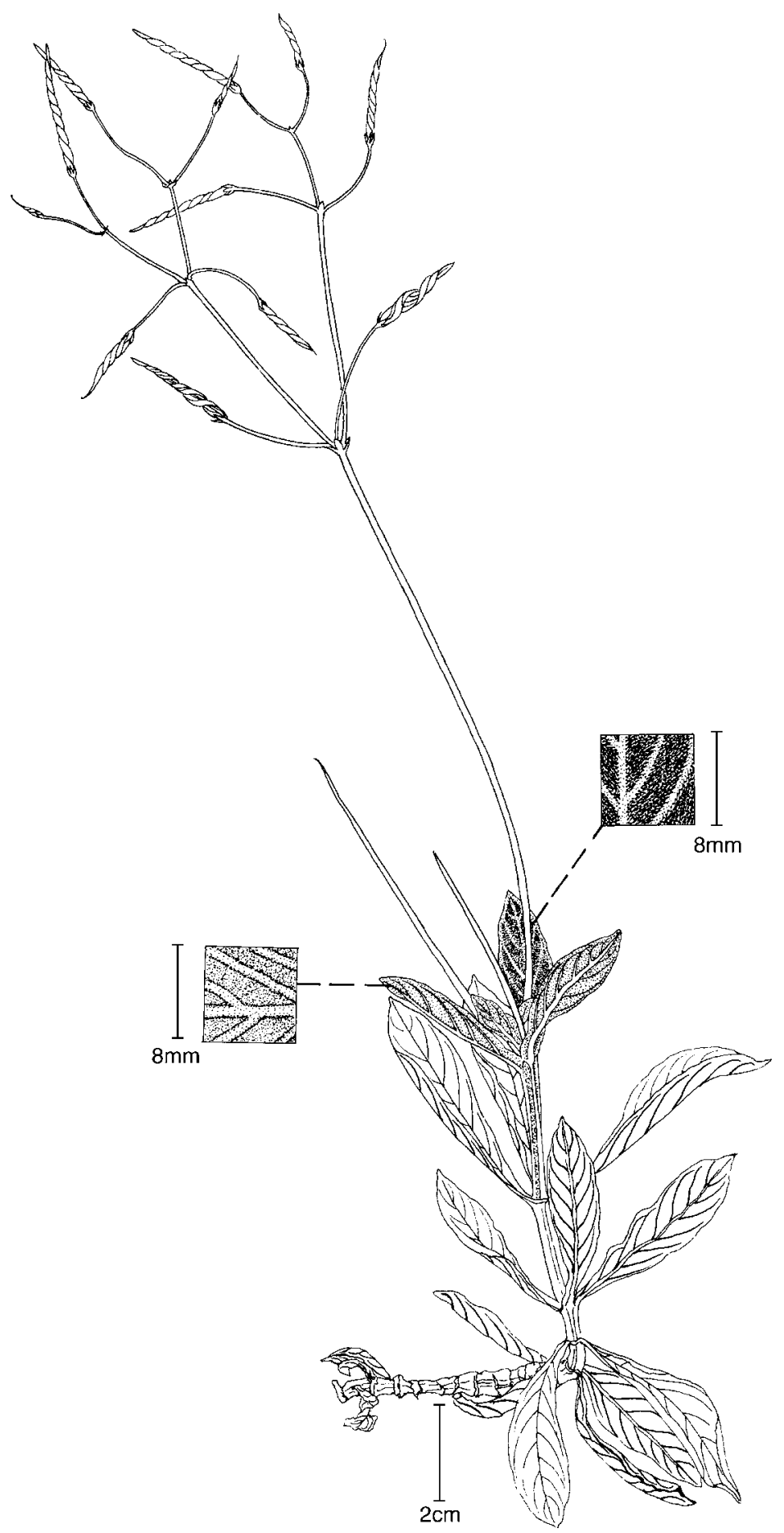

FIG. 16. Paraboea elegans (Ridl.) B.L.Burtt. 
Anthers transversely ellipsoid, c. $2 \times 3.5 \mathrm{~mm}$, coherent at the apex, opening in the centre of the anther locules, apex turned towards the gynoecium; filaments inserted at c. $0.5 \mathrm{~mm}$ from the corolla base with a free part c. $3 \mathrm{~mm}$ long. Gynoecium c. $10 \mathrm{~mm}$ long, $1 \mathrm{~mm}$ wide at the ovary base; stigma much larger than style. Fruit a linear capsule, 2-3 cm long, $2 \mathrm{~mm}$ wide, glabrous, spirally twisted. Seeds narrowly ovoid, $0.5 \times 0.2 \mathrm{~mm}$.

Distribution. Peninsular Malaysia and Peninsular Thailand.

Habitat and ecology. On quartzite or granite outcrops.

Proposed IUCN conservation assessment. Least Concern (LC). This species has been collected at several sites, some of which are in protected areas, and there are no major threats.

Additional specimens examined. Malaysia. Kedah: Kedah Peak [ $=$ G. Jerai $]\left[05^{\circ} 47^{\prime} \mathrm{N}\right.$ $\left.100^{\circ} 27^{\prime} \mathrm{E}\right], 23$ xii 1949 (fr), B. Allen s.n. (E); ibid., 2 viii 1919 (fr), M. Haniff \& Mee 4192 (K, SING); ibid., 1000 m, 3 xii 1915 (fr), H.C. Robinson \& Kloss 6062 (K); G. Jerai, 1984 (fr), A. Weber 84-0802 (KEP, WU); Pulau Langkawi, Gunung Machinchang [06 $\left.20^{\prime} \mathrm{N} 99^{\circ} 48^{\prime} \mathrm{E}\right], 8$ viii 1986 (fr), A. Weber 86-0808 (WU); ibid., $500 \mathrm{~m}, 1$ v 1962 (fr), B.L. Burtt \& P.J.B. Woods

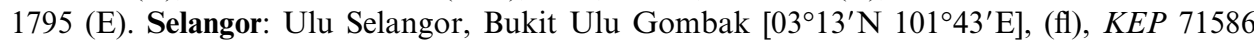
(KEP).

Thailand. Satun: Adang Island, Tarutao National Park [06 $\left.34^{\prime} \mathrm{N} 99^{\circ} 06^{\prime} \mathrm{E}\right]$, granite rocks, 300 m, 24 vi 1980 (fl, fr), Congdon 711 (AAU, E, PSU); Adang Island, near waterfall [Tarutao National Park], 22 x 1979 (fr), Congdon 87 (E).

Collections from Tarutao and Langkawi, previously Paraboea obovata but now reduced to synonymy (Burtt, 1971), differ from the typical sessile-leaved $P$. elegans by a distinct petiole up to $6 \mathrm{~cm}$ long. This species may be related to Paraboea minor and both are recorded from quartzite outcrops only. However, Paraboea elegans differs from $P$. minor in its whorled as opposed to opposite leaves.

25. Paraboea evrardii (Pellegr.) B.L.Burtt, Notes Roy. Bot. Gard. Edinburgh 41: 428 (1984). - Boea evrardii Pellegr. in Lecomte, Fl. Indo-Chine 4: 550 (1930). - Type: Vietnam, Lam Dong, Pongour near Di Linh (= Djiring) (Tuyen Duc, Lam Dong) [11 $41^{\prime} \mathrm{N} 108^{\circ} 16^{\prime} \mathrm{E}$ ], 20 v 1929 (fl), M. Evrard 1177 (lecto P, designated by Burtt (1984: 428); iso E).

Perennial rosulate herb, sometimes with a rhizome up to $25 \mathrm{~cm}$ long, with a thick woolly indumentum. Leaves congested in a rosette or on an elongate rhizome, petiolate; petiole $2-4 \mathrm{~cm}$ long, with a woolly or matted indumentum; blades elliptic or rounded, c.5-7 $\times 2.5-4 \mathrm{~cm}, 1.5-2$ times as long as wide, apex obtuse to rounded, base cuneate to rounded, upper surface with a distinct pubescence, lower surface with a greyish to brownish woolly (matted) indumentum; veins smooth or depressed above, raised beneath, lateral veins 5-8 pairs, more or less curved-ascending, tertiary venation indistinct or inconspicuous. Inflorescence axillary, cymose, rather tall but 
not very spreading, c.14-25 $\times 2-7 \mathrm{~cm}$, with few to many flowers, with a brownish woolly indumentum throughout except on the corolla and internal parts; peduncle 9-23 cm long, $1-1.5 \mathrm{~mm}$ in diameter, bracts indistinct; pedicels 2-10 $\mathrm{mm}$ long. Calyx $3 \mathrm{~mm}$ long, 5-lobed to the base; lobes ovate, $1.7 \times 1.2 \mathrm{~mm}$, with a brown matted indumentum outside, glabrous inside. Corolla blue, $10 \mathrm{~mm}$ across when fully open, $8 \mathrm{~mm}$ long; tube $2.5 \mathrm{~mm}$ long, pubescent outside, glabrous inside, limb 2-lipped; upper lip 2-lobed, lobes elliptic, $5 \times 3 \mathrm{~mm}$, lower lip 3-lobed, middle lobe larger than lateral lobes, ovate, c. $5 \times 5.5 \mathrm{~mm}$, lateral lobes similar in size to the upper lobes. Stamens 2, inserted at $0.5 \mathrm{~mm}$ from the base of the lower lip; filaments straight, glabrous, c. $1.7 \times 0.5 \mathrm{~mm}$; anthers yellowish farinose, ovoid, straight, not adnate to each other, c. $2.2 \times 1.2 \mathrm{~mm}$, opening towards the top of the anther. Ovary greenish farinose, ovoid, $2.5 \times 1 \mathrm{~mm}$, with the same type of glands as on the anthers; style glabrous, c. $3 \times$ $0.3 \mathrm{~mm}$; stigma a little larger than style, $0.4 \mathrm{~mm}$ in diameter, capitate, appearing pubescent. Fruit spirally twisted, 10-15 cm long, 1-2 mm in diameter. Seeds compressed.

Distribution. Vietnam.

Habitat and ecology. On limestone.

Proposed IUCN conservation assessment. Least Concern (LC). This species has been collected at several sites over a wide area and there are no major threats.

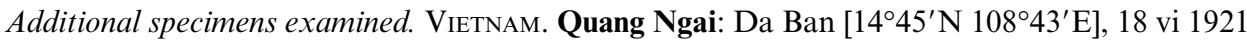
(fl, fr), B. Hayata 738 (P). Ninh Thuan: Phan Rang [11 $\left.34^{\prime} \mathrm{N} \mathrm{108} 8^{\circ} 59^{\prime} \mathrm{E}\right]$, vi 1909 (fl, fr), A.C. D'Alleizette s.n. (L); ibid., 200 m, 20 viii 1922 (fl, fr), E. Poilane 20888 (P); Phan Rang, vallee du Song Cay [10²7'N 107²2'E], 28 ix 1940 (fl, fr), E. Poilane 30612 (P).

This species is part of the Paraboea multiflora group (see discussion under that species). When Pellegrin (1930) described Boea multiflora R.Br. var. villosa, he cited two specimens from Laos [Thorel 2353 (P) and Poilane $12188(\mathrm{P})$ ] and one specimen from Vietnam [B. Hayata $738(\mathrm{P})]$ as syntypes for the varietal name. In this study we have lectotypified Boea multiflora var. villosa with Poilane 12188 and have removed B. Hayata 738 to Paraboea evrardii. Hayata 738 (P) has both white and violet flowers, rather intermediate between the Laos and Vietnamese collections. The corolla colour may not be reliable as a specific character in this genus and the status of this taxon may need to be reviewed in the future with more collections.

26. Paraboea ferruginea (Ridl.) Ridl., J. Straits Branch Roy. Asiat. Soc. 44: 68 (1905); Burtt, Notes Roy. Bot. Gard. Edinburgh 41: 428 (1984). - Boea ferruginea Ridl., J. Linn. Soc., Bot. 32: 521 (1896). - Type: Peninsular Malaysia, Langkawi Island [c.06 $20^{\prime} \mathrm{N} 9^{\circ} 48^{\prime} \mathrm{E}$ ], ix 1890, Curtis 2566 (lecto SING, designated here; iso $\mathrm{E})$.

Perennial herb, rosulate, sometimes with rhizome up to $10 \mathrm{~cm}$ long, with dense ferrugineous long simple pubescence especially on petioles and inflorescence. Leaves 
congested in a rosette, petiolate; petiole $2-10 \mathrm{~cm}$ long; blades \pm obovate, $3.5-9 \times$ $2.5-7.5 \mathrm{~cm}, \mathrm{c} .1 .5$ times as long as wide, apex rounded to shallowly emarginate, margin \pm crenate, densely minute-pubescent above, with a ferrugineous long pubescence and a brownish matted indumentum beneath; veins smooth above, raised beneath, lateral veins c.5 pairs, most of them inserted near petiole and so slightly similar to a palmate venation, tertiary venation visible. Inflorescence axillary, seemingly capitate, numerous flowers congested at the apex of a long peduncle, primary and secondary branches and pedicels hardly seen when in flower and pedicels extending to only $5-10 \mathrm{~mm}$ long in fruit, with ferrugineous long pubescence on the whole inflorescence except for the fruit [the long hairs on the inside of the calyx can be as long as the calyx itself]; peduncle c.5-8 cm long, bracts sepal-like. Corollas not seen; calyx persistent, $6.5 \mathrm{~mm}$ long, 5-lobed to the base, lobes narrowly oblong. [Fide Ridley: Calyx lobes as long as the corolla. Corolla tube very short, limb explanate, not bilabiate, lobes broad obovate, obtuse, subequal and similar, white or tinted with rose. Stamens 2, short, filaments broad spathulate, thick, apex toothed, anthers conic, connate by the tips. Style no longer. Ovary conic. Stigma rounded, entire, discoid.] Fruit an ovoid non-twisted capsule, shorter than the calyx, 2-4 mm long, $0.8 \mathrm{~mm}$ wide, glabrous.

Distribution. Peninsular Malaysia: Langkawi Islands.

Habitat and ecology. Occurring in shady rocky niches on limestone substrate.

Proposed IUCN conservation assessment. Least Concern (LC). This species has been collected at several sites and there are no major threats.

Additional specimens examined. Malaysia: Kedah: Langkawi Islands, P. Bumbon Besar/P. Chupak [06 $17^{\prime} \mathrm{N} 99^{\circ} 52^{\prime} \mathrm{E}$ ], 3 xi 1971 (fr), J. Boey 494 (KLU); P. Bumbon Kechil [06²0'N 99 55'E], 28 iv 1962 (fr), B.L. Burtt \& P.J.B. Woods 1761 (E); P. Dayang Bunting S. end $\left[06^{\circ} 13^{\prime} \mathrm{N} 99^{\circ} 49^{\prime} \mathrm{E}\right], 29$ iv 1962 (lv), B.L. Burtt \& P.J.B. Woods 1762 (E); Langkawi Island [c.06 $20^{\prime} \mathrm{N} 99^{\circ} 48^{\prime} \mathrm{E}$ ], iv 1892, Curtis 2566 (K); Langkawi, xi 1901 (fl), C. Curtis s.n. (K); W Coast $\left[06^{\circ} 21^{\prime} \mathrm{N} 99^{\circ} 52^{\prime} \mathrm{E}\right]$, xi 1916, H.C. Robinson 6223 (E?); Selat Pan Chor, forested limestone rocks near country club $\left[06^{\circ} 25^{\prime} \mathrm{N} 99^{\circ} 43^{\prime} \mathrm{E}\right], 6$ viii 1986 (fr), A. Weber 86-0806 (KEP, WU).

Thailand. Kanchanaburi: Khao Pattawee [c. $13^{\circ} 59^{\prime} \mathrm{N} 99^{\circ} 20^{\prime} \mathrm{E}$ ], in crevices of limestone, 90 m, 18 xi 1961 (fr), K. Larsen 8311 (ABD).

This species is unique in the genus in its combination of a long pubescence with a distinct ferrugineous colour and its seemingly palmate venation. The indumentum occurs throughout the whole plant and the hairs can be as long as the calyx. This species may be related to Paraboea bakeri. Both species have a similar habit and leaf morphology, and have the same long calyx and short capsule. The locality of the single specimen from Thailand is quite distant from the other collections and its status should be reinvestigated with better collections.

27. Paraboea filipes (Hance) B.L.Burtt, Notes Roy. Bot. Gard. Edinburgh 41: 429 (1984). - Oreocharis filipes Hance, J. Bot. 21: 166 (1883). - Type: China, Kwantung 
(Guangdong), Lien-shau river (Lianjiang), near Young-tin narrows $\left[24^{\circ} 50^{\prime} \mathrm{N}\right.$ $112^{\circ} 25^{\prime} \mathrm{E}$ ], 290 m, 12 x 1881 (fr), B.C. Henry in herb. Hance 22137 (holo BM).

Perennial rosulate herb, very small. Leaves (oppositely?) congested in a rosette, petiolate; petiole 2-6 mm long, with a whitish matted indumentum; blades obovate, $1-4 \times 0.3-1.5 \mathrm{~cm}$, c. $2-3$ times as long as wide, apex rounded, base slightly peltate and rounded, margin entire, upper surface glabrous, lower surface with a whitish matted indumentum; midrib smooth above, raised beneath; lateral veins smooth above, hardly visible beneath, c. 4 pairs, tertiary venation invisible. Inflorescence axillary, cymose, few-flowered, longer than the leaves, c. $5 \mathrm{~cm}$ long, primary and secondary branches not much developed, glabrous; peduncle c.4 cm long, bracts narrowly oblong-ovate, c. $1 \mathrm{~mm}$ long; pedicel $15 \mathrm{~mm}$ long. Calyx 5-lobed to the base, lobes ovate-triangular, $2 \times 0.6 \mathrm{~mm}$, more or less farinose inside, outside glabrous. Corolla purplish, $4 \mathrm{~mm}$ long, $3.5 \mathrm{~mm}$ across, glabrous outside; tube $3 \mathrm{~mm}$ long, limb slightly 2-lipped; 5 lobes all similar, rounded, c. $1.3 \times 2 \mathrm{~mm}$. Anthers transversely ellipsoid, c. $1 \times 2 \mathrm{~mm}$, apex turned towards the gynoecium, dorsifixed; filaments $1.5 \mathrm{~mm}$ long; staminodes $0.2 \mathrm{~mm}$ long. Gynoecium $4.5 \mathrm{~mm}$ long; ovary $1.5 \times 0.8 \mathrm{~mm}$; style distinct, $3 \times 0.2 \mathrm{~mm}$; stigma slightly larger than style. Fruit a non-twisted capsule, narrowly ovoid, $0.6 \mathrm{~cm}$ long, $1 \mathrm{~mm}$ wide, glabrous.

Distribution. China: North Guangdong.

Habitat and ecology. Reported from limestone cliffs, elevation c.100-300 m.

Proposed IUCN conservation assessment. Endangered (EN B1ab(ii,iii,v)). This species is only known from two localities. Although the extent of occurrence is clearly $<100 \mathrm{~km}^{2}$, which would justify a Critically Endangered category, the two localities reduces the threat somewhat and Endangered is a more suitable category.

Additional specimen examined. CHina. Guangdong: Lian Xian on cliffs along the Lian River bank, 100 m, 29 x 1985 (fl), Z. Y. Li et al. 425 (E).

Burtt (1984) has discussed the relationship between this species and Paraboea velutina, the only two species of this genus then known from China that have nontwisted capsules.

28. Paraboea glabra (Ridl.) B.L.Burtt, Notes Roy. Bot. Gard. Edinburgh 22: 311 (1958) [but excluding the cited collections except for the type]; Burtt, Notes Roy. Bot. Gard. Edinburgh 41: 429 (1984). - Boea glabra Ridl., J. Linn. Soc., Bot. 32: 521 (1896). - Type: Thailand, Poongah, cult. Penang, C. Curtis 3039 (lecto K, designated by Burtt (1984: 429)).

Paraboea rupestris B.L.Burtt, Notes Roy. Bot. Gard. Edinburgh 41: 436 (1984). - Type: Thailand, Peninsular region, Surat, Khao Pak Chong, $55 \mathrm{~km} \mathrm{~W} \mathrm{of} \mathrm{Surat}$ on Tekuapa road, $100 \mathrm{~m}$, herb on limestone rocks, flowers white, leaves brown below, 25 ix 1963, Smitinand et al. 1277 (holo E; iso BKF, K, L). 
Perennial caulescent herb; stem woody, 20-50 cm long, $8 \mathrm{~mm}$ in diameter; internodes normally $2-5 \mathrm{~cm}$ long, with a dense layer of matted indumentum, so dense that it could be misunderstood for a glabrous bark (Burtt, 1984). Leaves opposite, petiolate; petiole $2-5 \mathrm{~cm}$ long, swelling at the node and joining the opposite one to form a distinct auricle surrounding the node, with the same kind of indumentum as that on the stem; blades elliptic or narrowly so, $6-18 \times 2.5-5.5 \mathrm{~cm}$, 2-3.5 times as long as wide, apex obtuse, base cuneate or shortly angustate, margin shallowly serrate, upper surface glabrous, lower surface with a dense layer of brownish orange or greyish matted indumentum, so dense and so smooth that the surface appears glabrous; veins obscure or inconspicuously depressed above, raised beneath, lateral veins c. 6 pairs. Inflorescences subterminal, cymose, c. $20 \mathrm{~cm}$ long, often 2 opposite from the axils below the apical bud; flower buds congested in the young inflorescence like a capitulum and the inflorescence gradually developing into an extended one-sided cincinnus; peduncle $\mathrm{c} .10 \mathrm{~cm}$ long with a matted indumentum; on every fertile node of the flowering branch with only one pairflower unit, c.10 pairs or less on a single cyme, a sterile node located in-between each of the two fertile nodes, both the fertile node and the sterile node with a narrowly ovate-oblong or slightly obovate bract, c. $1 \mathrm{~cm}$ long, the flowering branch twisted to make the sterile bract just alternate on the opposite side to the fertile bract; pedicels c. $5 \mathrm{~mm}$ long, more or less with a matted indumentum. Calyx relatively large, 6-8 $\mathrm{mm}$ long, 5-lobed to the base, lobes oblong-obovate, 5-7 $\mathrm{mm}$ long, 2-3 mm wide, apex \pm truncate, with some matted indumentum outside, glabrous inside. Corolla white, glabrous, c. $10 \mathrm{~mm}$ long; tube c. $5 \mathrm{~mm}$ long, limb indistinctly 2-lipped; upper lip 2-lobed, lobes wide-ovate, c. $6 \times 8 \mathrm{~mm}$, lower lip 3-lobed, lobes of similar shape and size. Anthers transversely ellipsoid, c. $2.5 \times$ $4 \mathrm{~mm}$, coherent with each other at the apex, opening in the centre of the anther locules, dorsifixed, apex pointing towards the gynoecium; filaments inserted at c. $2 \mathrm{~mm}$ from the corolla base with a free part c. $3 \mathrm{~mm}$ long; 2 staminodes seen, scale-like, c. $1 \mathrm{~mm}$ long. Gynoecium c. $8.5 \mathrm{~mm}$ long, $1.8 \mathrm{~mm}$ wide at the ovary base; stigma slightly larger than style. Mature fruit not seen; young fruit a visibly twisted capsule, glabrous.

Distribution. Peninsular Thailand.

Habitat and ecology. On limestone.

Proposed IUCN conservation assessment. Vulnerable (VU D2). This species is currently only known from three independent collections: two from Surat Thani and one unknown. As it is currently known from so few localities and limestone areas in Thailand are often exploited for cement, or subject to fires from surrounding agricultural land, it should be considered Vulnerable. This species was also included in Pooma (2005) as threatened in Thailand.

Additional specimens examined. Thailand. Phangnga: 'Poongah', ii 1893 (fl), C. Curtis 3039 (K). Surat Thani: 15 viii 1975 (fl), D. Praphat 24 (BKF, E). 
When Ridley (1896) published Boea glabra he indicated 'Though I have seen no fruit, there can be little doubt but that this is a Boea [i.e. fruits twisted]'. Burtt, however, annotated a group of specimens with non-twisted capsules as B. glabra (= Paraboea glabra). These have been recognised as Paraboea burttii in this study. The two species, Paraboea glabra and P. burttii, not only differ in their twisted and nontwisted capsules, but also differ in their inflorescences, i.e. typical axillary capitate cymes vs. subterminal monochasial cincinnus (cyme).

The type of Ridley's (1896) specific name is poor but its identity is clear from the subterminal cymose inflorescence and the juvenile capitulate inflorescence in which flower buds are congested and embraced by bracts. Furthermore the characteristic obtrapeziform (or oblong-obovate) calyx lobes are apparent in the young flowers. The type material of Paraboea rupestris has exactly the same characters and is here reduced to synonymy.

The inflorescence is unique in the whole genus. The non-branched (or non-forked) 'cyme' could have evolved from a normal dichasial (or two-forked) cyme that alternately reduced the opposite branch into a pair-flower unit. The alternate arrangement of sterile and fertile nodes implies this possibility.

Despite the similarity in the calyx lobes with Paraboea burttii and in the capitulum-like appearance of the young inflorescence with $P$. bintangensis, $P$. glabra is unlikely to be closely related to these two. The above two species do not possess a subterminal inflorescence which appears capitate or umbellate and produce nontwisted fruits. It is more likely to be close to Paraboea acutifolia.

29. Paraboea glabriflora (Barnett) B.L.Burtt, Notes Roy. Bot. Gard. Edinburgh 41: 429 (1984). - Boea glabriflora Barnett, Nat. Hist. Bull. Siam Soc. 20: 19 (1961); Barnett, Kew Bull. 15: 252 (1961). - Type: Thailand, Surat, Ben Kawp Kep [0909'N 99²0'E], 100 m, 16 viii 1927 (fr, fl), A.F.G. Kerr 13362 (lecto K, designated by Barnett, Kew Bull. 15: 252 (1961)).

Perennial rosulate herb (with a root stock c.7 cm long, fide Barnett's original description). Leaves opposite and congested at the apex of the root stock, petiolate; petioles $3.3-7 \mathrm{~cm}$ long, with some indumentum, enlarged at the base and seemingly joining each other across the stem; blades elliptic, $4.5-8 \times 3.2-5 \mathrm{~cm}, 1.5-2$ times as long as wide, apex rounded, base rounded or cuneate, unequal, margin crenate, chartaceous, pale greyish-green above and pale tawny below when dry, upper surface with a sparse white-pubescence, lower surface with a sparse tawny matted indumentum (more densely so on the midrib and the lateral veins); veins smooth above, raised beneath, lateral veins 5-6 pairs, tertiary venation inconspicuous. Inflorescence axillary from the axils below the apical bud of the rosette, dichasial, lax, many-flowered; peduncles slender, glabrous, up to $30 \mathrm{~cm}$ long, with two bracts at the apex, bracts slender, c. $2.5 \mathrm{~mm}$ long, glabrous; pedicels slender, up to c. $20 \mathrm{~mm}$ long, glabrous. Calyx 5-lobed to the base, lobes linear, obtuse, c. $2.5-3 \mathrm{~mm}$ long, c. $0.4 \mathrm{~mm}$ wide, glabrous, persistent in fruit. Corolla pink, c. $0.5 \mathrm{~cm}$ long, $1.3 \mathrm{~cm}$ across in open 
flower; tube c. $2 \mathrm{~mm}$ long, limb 2-lipped; upper lip with 2 lobes, lobes widely ovate, c. $3 \times 3 \mathrm{~mm}$, lower lip c. $0.5 \times 1 \mathrm{~cm}, 3$-lobed, middle lobe c. $3 \times 4 \mathrm{~mm}$, lateral lobes of similar size and shape. Anthers transversely ellipsoid, c. $1 \times 2.5 \mathrm{~mm}$, coherent with each other at the apex, opening in the centre, dorsifixed, apex slightly turned towards the gynoecium; filaments inserted at c. $0.5 \mathrm{~mm}$ from the corolla base with a free part c. $1 \mathrm{~mm}$ long, flat; only 1 staminode seen, $0.5 \mathrm{~mm}$ long. Ovary ovoid, c. $2 \times 0.7 \mathrm{~mm}$; style much more slender than the ovary, c. $4.5 \mathrm{~mm}$ long; stigma not much larger than style. Fruit a slender capsule, c. $3-3.5 \mathrm{~cm}$ long, $1 \mathrm{~mm}$ in diameter, glabrous, spirally twisted. Seeds elliptic, flat, $0.4 \times 0.1 \mathrm{~mm}$.

Distribution. Thailand. Known only from the type.

Habitat and ecology. Unknown.

Proposed IUCN conservation assessment. Data Deficient (DD). This category has been used due to the uncertainty over the taxonomic status of this species (see note below).

The type material is not very good and since its publication no more records have been added. From the leaf morphology and the inflorescence structure this species may be conspecific with Paraboea brunnescens (see discussion under that species).

30. Paraboea glabrisepala B.L.Burtt, Kew Bull. 1941: 21 (1941); Barnett, Kew Bull. 15: 255 (1961); Burtt, Notes Roy. Bot. Gard. Edinburgh 41: 429 (1984). - Boea glabrisepala (B.L.Burtt) Barnett, Kew Bull. 15: 255 (1961). - Type: Thailand, Payap [Chiang Mai], Doi Chiengdao, 28 xiii 1935 (fl), H.B.G. Garrett 1001 (lecto K, first step designated by Barnett (1961: 255), second step designated here; iso K, L). Fig. 17.

Perennial rosulate herb. Leaves congested in a rosette, petiolate; petiole very long, normally $10-19 \mathrm{~cm}$ long, with the same indumentum as that on the lower leaf surface; blades oblong, elliptic or narrowly so, 10-21.5 × 3.5-14.2 cm, 1.5-2 times as long as wide, apex obtuse or rounded, base cuneate, truncate or sometimes slightly cordate, margin crenate, upper surface with some arachnoid covering or glabrescent, lower surface with a whitish brown matted indumentum; veins obscure or slightly depressed above, raised beneath, lateral veins c. 8 pairs, tertiary venation conspicuously reticulate. Inflorescence axillary, cymose, with a very long peduncle normally equal to or longer than leaves; peduncle $20-40 \mathrm{~cm}$ long, robust, with a matted indumentum when young, then glabrescent when older, with 2 large bracts that are membranous and widely ovate, c. $1.5 \times 2 \mathrm{~cm}$, embracing the juvenile inflorescence; primary branches $1-4 \mathrm{~cm}$ long, secondary ones hardly developed and so the inflorescence appearing quite congested, many-flowered, all other bracts with similar morphology to the two peduncle bracts but gradually reducing in size; pedicel normally c.5 mm long. Calyx exceptionally small, c. $1.5 \mathrm{~mm}$ long, 5-lobed, lobes c. $1 \mathrm{~mm}$ long, $1 \mathrm{~mm}$ wide, apex emarginate, glabrous. Corolla pale violet, glabrous, c. $7 \mathrm{~mm}$ long, $6 \mathrm{~mm}$ across (possibly not a fully mature corolla); tube c. $5 \mathrm{~mm}$ long, slightly swelling at the base of the lower lip, limb 2-lipped; upper lip 2-lobed, lobes 


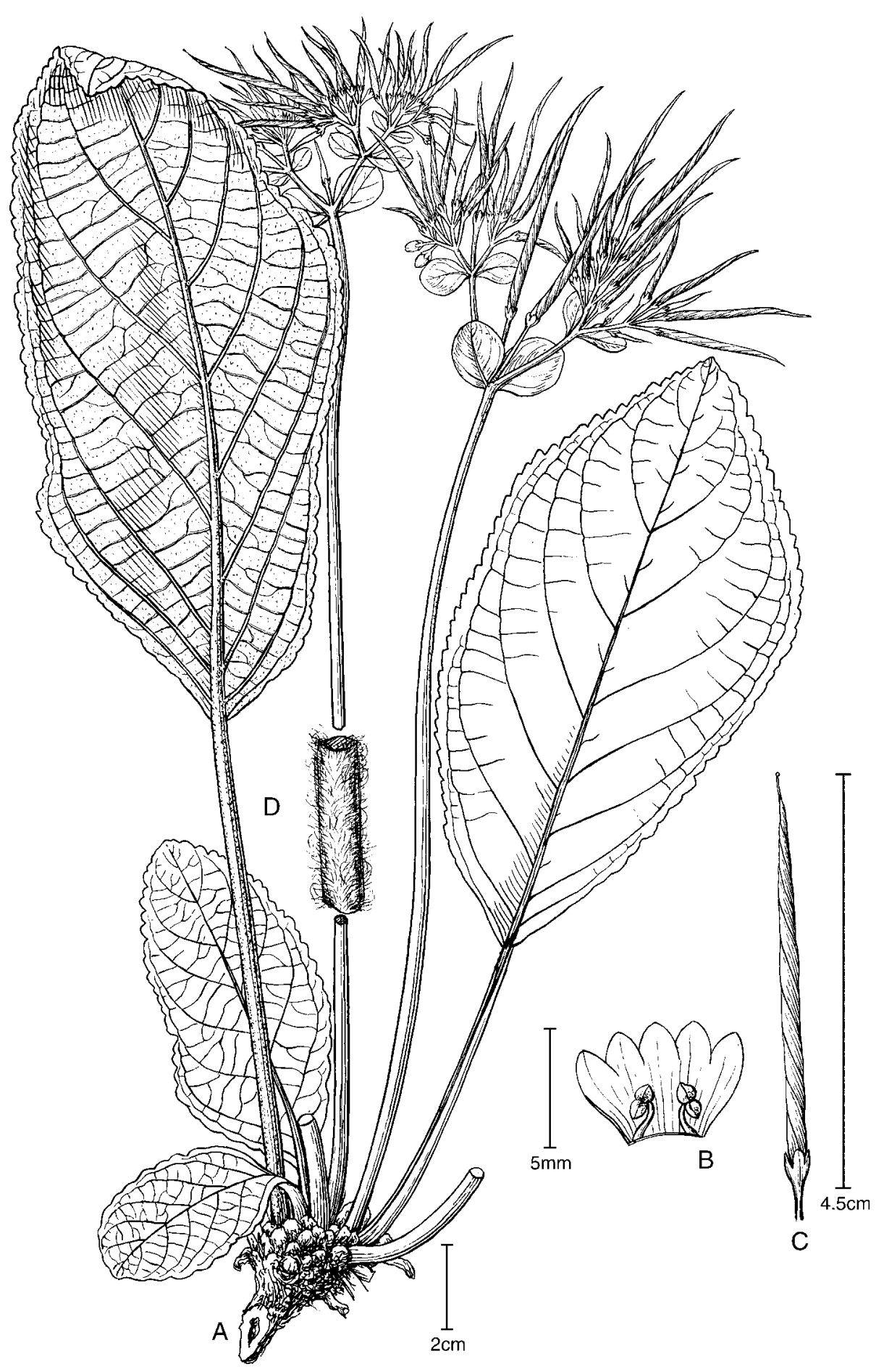

FIG. 17. Paraboea glabrisepala B.L.Burtt. A, habit; B, corolla opened out; C, fruit; D, section of peduncle. 
widely ovate, c. $2.5 \times 3 \mathrm{~mm}$, lower lip larger than the upper lip, 3-lobed, lobes similar in size to the upper lip lobes. Anthers transversely ellipsoid, c. $2 \times 4 \mathrm{~mm}$, coherent with each other at the apex, apertured at the upper end, apex pointing towards the gynoecium, basifixed; filaments inserted at c. $1 \mathrm{~mm}$ from the corolla base with a free part c. $4 \mathrm{~mm}$ long, exceptionally pubescent; staminodes 3, two lateral ones $2 \mathrm{~mm}$ long, dorsal one $0.75 \mathrm{~mm}$ long. Gynoecium c.7-9 $\mathrm{mm}$ long, $1 \mathrm{~mm}$ wide at the ovary base; stigma not enlarged, \pm oblique. Fruit a linear capsule, $3.7-4.4 \mathrm{~cm}$ long, $1.5-2 \mathrm{~mm}$ in diameter, glabrous, spirally twisted. Seeds ellipsoid, $0.6 \times 0.15 \mathrm{~mm}$.

Distribution. Northern Thailand.

Habitat and ecology. On limestone.

Proposed IUCN conservation assessment. Least Concern (LC). Although this species has been collected at few sites one of them is the well-protected and extensive Doi Chiangdao National Park.

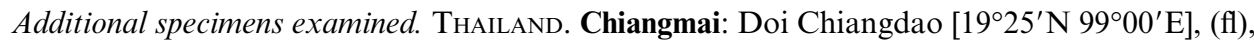
K. Boonchuai 948 (BKF); Doi Chiangdao, 680 m, 14 viii 1949 (fr), H.B.G. Garrett 1260 (K, L); Doi Chiangdao, north side of Doi Luang, above Sop Huay Pah Dahng-Huay Nah Lao Station, 1000 m, 8 x 1995, J.F. Maxwell 95-857 (L); Doi Chiangdao, east side, Pa Blawng Cave area, 575 m, 5 viii 1989, Maxwell 89-992 (A). Mae Hong Son: Doi Pui, SE of Mae Hong Son, $19^{\circ} 13^{\prime} \mathrm{N} 98^{\circ} 02^{\prime} \mathrm{E}, 800$ m, 23 ix 1995 (fr), Larsen et al. 46840 (AAU, SING).

Burtt (1941) apparently had no fruiting material but suggested that the plant had non-twisted capsules by placing it in Paraboea (capsules non-twisted), as then defined. He compared his species to Paraboea capitata. Barnett (1961) saw fruiting material with twisted capsules and so moved it to Boea (capsules twisted). On revising the generic concepts in Paraboea and Boea, Burtt (1984) resurrected the original name. However, this species does not appear to be close to Paraboea capitata for it is different from the latter species in the large corolla with a long tube and short limb (vs. smaller corolla with short tube but large limb), by the pattern of anthers opening at the upper end (vs. open in the middle) and by having pubescent filaments (vs. glabrous), not to mention the capsule difference. It is possibly closer to species such as Paraboea sinensis and P. glanduliflora which also have large bracts.

31. Paraboea glanduliflora Barnett, Nat. Hist. Bull. Siam Soc. 20: 14 (1961); Barnett, Kew Bull. 15: 252 (1961); Burtt, Notes Roy. Bot. Gard. Edinburgh 41: 429 (1984). - Type: Thailand, Payap [Chiang Mai], Doi Chiangdao [19²5'N 9900'E], 2000 m, 16 vii 1958 (fl), Smitinand 4728 (lecto E, designated by Barnett, Kew Bull. 15: 252 (1961); iso BKF). Fig. 18.

Perennial caulescent herb with a woody stem, 15-30 cm long, $5 \mathrm{~mm}$ in diameter; internode length varying from $0.5-5 \mathrm{~cm}$ long. Leaves opposite, petiolate; petiole (1-)3-7 cm long, with narrow wings joining at the node; blades elliptic or slightly obovate, $8-15 \times 5-9 \mathrm{~cm}$, c.1.5 times as long as wide, apex acute, base shortly angustate or rounded, margin serrate, upper surface pubescent, lower surface 


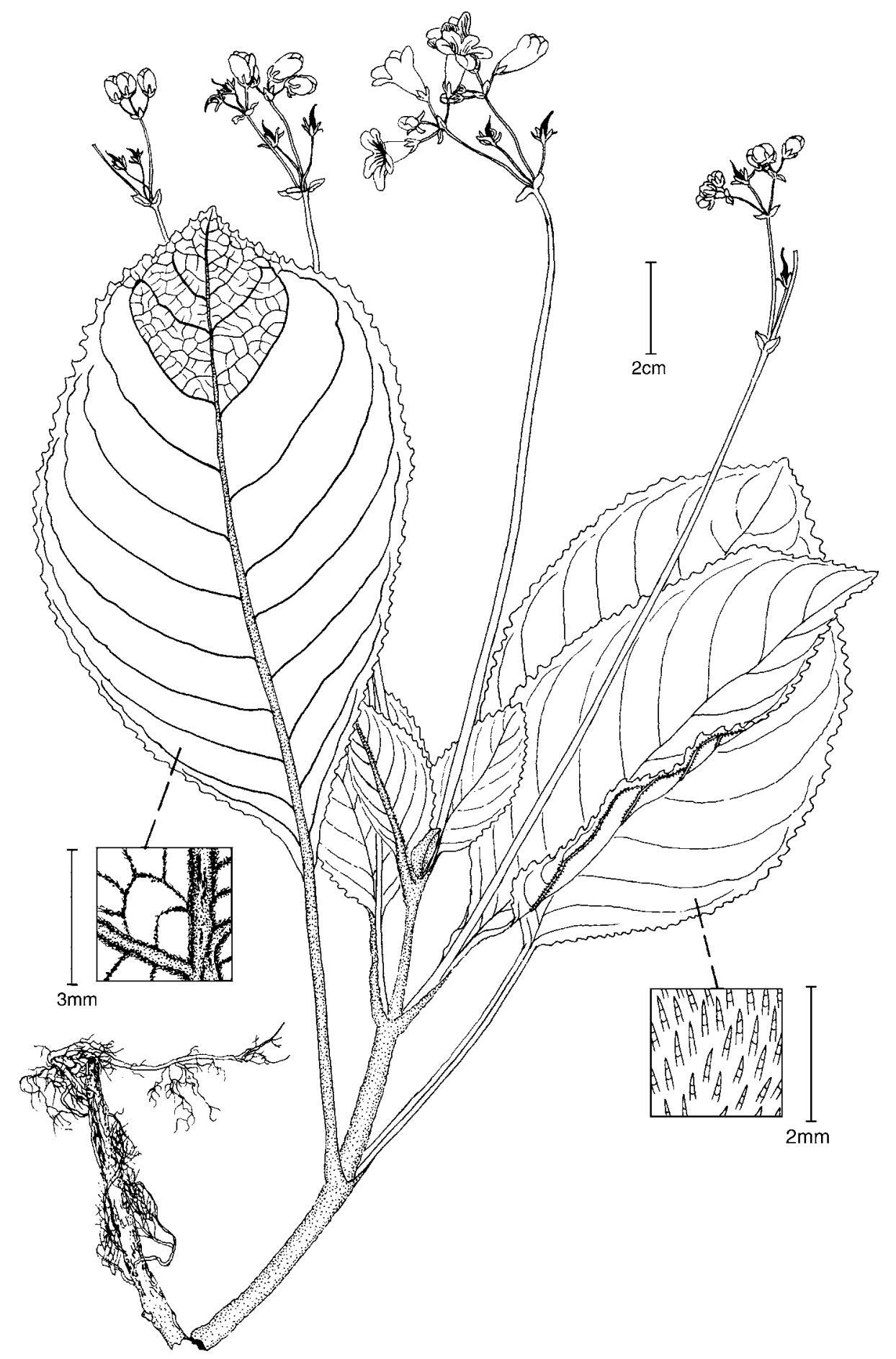

FIg. 18. Paraboea glanduliflora Barnett. 
scabrous and with a matted indumentum on the veins; veins obscure above, raised beneath, lateral veins c.10 pairs, tertiary venation reticulate. Inflorescences subterminal cymose, often 2 or 4 growing in the opposite pairs of axils towards the apical bud, 15-20 cm long, c.4-5 cm wide, many-flowered; peduncle 10-15 cm long, glabrous, with 2 rounded bracts, $5 \mathrm{~mm}$ long, glabrous; pedicels c.5 mm long, glandular-pubescent, with bracts smaller than but of similar shape to those on the peduncle. Calyx $3 \mathrm{~mm}$ long, 5-lobed to the base, lobes narrowly oblong, c.3.5 $\times$ $1 \mathrm{~mm}$, rounded at the apex, more or less glandular-pubescent outside, glabrous inside. Corolla pink or pinkish-purple, c. $1.8 \mathrm{~cm}$ long, $1.2 \mathrm{~cm}$ across; tube c.7 $\mathrm{mm}$ long, $7 \mathrm{~mm}$ in diameter, glandular-pubescent outside, glabrous inside, limb 2-lipped; upper lip 2-lobed, lobes widely ovate, c. $2.5 \times 5.5 \mathrm{~mm}$, lower lip c. $7 \mathrm{~mm}$ long, $8 \mathrm{~mm}$ wide, 3-lobed, middle lobe rounded, c. $4 \times 4.5 \mathrm{~mm}$, lateral lobes widely ovate, c. $2 \times$ $4.5 \mathrm{~mm}$. Anthers transversely ellipsoid, c. $1.2 \times 3 \mathrm{~mm}$, glabrous, coherent with each other at the apex, apertured at the upper end, basifixed, apex turned towards the gynoecium; filaments inserted at the corolla base with a free part c. $6 \mathrm{~mm}$ long, curved to form a knee, with glandular hairs; staminodes 3, c.1 mm long, hairy. Gynoecium c.9 mm long, $1.2 \mathrm{~mm}$ wide at the base of the ovary, glabrous; style c. $7 \mathrm{~mm}$ long, stigma oblique. Fruit a linear capsule, c. $3-4 \mathrm{~cm}$ long, $1.5 \mathrm{~mm}$ wide, glabrous, spirally twisted. Seeds ellipsoid, $0.6 \times 0.2 \mathrm{~mm}$.

Distribution. Burma and Thailand.

Habitat and ecology. On limestone.

Proposed IUCN conservation assessment. Least Concern (LC). Although this species has been collected at few sites one of them is the well-protected and extensive Doi Chiangdao National Park.

Additional specimens examined. Burma. Taunggyi $\left[20^{\circ} 49^{\prime} \mathrm{N} 97^{\circ} 01^{\prime} \mathrm{E}\right]$, Taunggyi Reserve, 1666 m, 27 ix 1970 (fl, fr), U. Mg Gale 12146 (A); Taunggyi, c. 1500 m, 13 viii 1934, R. Malaise $312(\mathrm{~S})$.

Thailand. Chiangmai: Doi Chiangdao, Doi Pee $\left[19^{\circ} 25^{\prime} \mathrm{N} 99^{\circ} 00^{\prime} \mathrm{E}\right], 17$ xi 1963 (fr), Adisai 670 (BKF); Doi Chiangdao, 15 xi 1962 (fl), K. Bunchuai BKF47649 (BKF); Doi Chiangdao, K. Bunchuai 968 (BKF); Doi Chiangdao, 2000 m, xi 1962 (fr), Cult. in E C5138 (E); Doi Chiangdao, 1300-1900 m, 26 ix 1971 (fr), G. Murata et al. T-15072 (L); Doi Chiangdao, 1300-1900 m, 27 ix 1971 (fl), G. Murata et al. T-15185 (L); Doi Chiangdao, 30 vi 1965 (fl), T. Smitinand et al. 7824 (E); Doi Chiangdao, 1620 m, 24 vii 1990, H. Banziger 704 (L).

This species may have some affinity to Paraboea pubicorolla. Both have some glandular pubescence on the corolla and the same pattern of subterminal cymose inflorescences. However, the scabrous leaf surface of this species is very different to the smooth leaf surface of Paraboea pubicorolla. Paraboea glanduliflora also shares some common characters with $P$. glabrisepala in corolla shape, stamen morphology, the gynoecium and bract morphology. Barnett (1961) supposed her species to have non-twisted capsules so she placed it in Paraboea (with non-twisted 
capsules) rather than in Boea (with twisted capsules). It is now known that this species has twisted capsules and now only belongs in Paraboea due to the recircumscription by Burtt (1984). In our study we have found that all species with a subterminal cymose inflorescence possess twisted capsules rather than non-twisted capsules.

32. Paraboea glutinosa (Hand.-Mazz.) K.Y.Pan, Novon 7: 431 (1997). - Boea glutinosa Hand.-Mazz., Sinensia 7: 620 (1936). - Type: China, Kwangsi (Guangxi) ad confines prov. Kweichow (Guizhou), 8 km ad merid. pagi Nibai, 700 m, 29 vi 1928 (fl), R.C. Ching 6317 (holo WU; iso W). [The specimen label indicates '15 li s. of Neo Bai, border of Kweichow'. The Chinese 'li' is the unit for $0.5 \mathrm{~km}$. Consequently, the possible locality for the type collection should be: Guangxi, on the border with Guizhou Province, 7.5 km S from Baile, c. $24^{\circ} 44^{\prime} \mathrm{N} 106^{\circ} 08^{\prime}$ E.] Fig. 19.

Perennial rosulate herb with a short rhizome. Leaves opposite, 5-10 pairs congested on the short above-ground stem, petiolate; petiole 3-7 cm long, with 2 narrow wings extending from the leaf base and joining across the node; blade elliptic or narrowly so, 10-18 $\times 3.5-9 \mathrm{~cm}, 1.5-4.5$ times as long as wide, apex obtuse, base attenuate or shortangustate, margin entire or crenate, upper surface with some arachnoid covering or glabrescent, lower surface with a matted indumentum; veins obscure above, raised beneath, lateral veins $10-13$ pairs, tertiary venation inconspicuously reticulate. Inflorescence a terminal panicle and axillary cymes from the basal leaves, c.40-60 $\times$ $20-40 \mathrm{~cm}$, with a matted indumentum on the flowering stem and the floral leaves, more or less pubescent on peduncles and pedicels; flowering stem with long internodes (normally $>10 \mathrm{~cm}$ long), floral leaves similar in size and shape to vegetative leaves; the flowering stems of the axillary cymes up to $40 \mathrm{~cm}$ long, many-flowered; pedicels 10-30 mm long, bracts sepal-like. Calyx 2.5-3 mm long, 5-lobed to the base, lobes narrowly ovate, c. 3 times as long as wide, glabrous or rarely with a little pubescence. Corolla white (or pale violet), 1-2 cm long, $0.5-1.2 \mathrm{~cm}$ wide, glabrous or rarely with a little pubescence; tube up to $1 \mathrm{~cm}$ long, slightly swelling in the middle, limb 2-lipped; posterior lip with 3 lobes, middle lobe rounded, lateral lobes widely ovate, c. $3 \times$ $3.2 \mathrm{~mm}$; anterior lip with 2 lobes, wide-ovate, c. $2.5 \times 3.5 \mathrm{~mm}$. Stamens 2, staminodes sometimes present; anthers transversely ellipsoid, $2.5 \times 4 \mathrm{~mm}$, dorsifixed, coherent with each other in the middle; filaments c. $8 \mathrm{~mm}$ long, curved in the middle to form a knee, covered by a beard of multicellular hairs. Gynoecium c. $7 \times 1.2 \mathrm{~mm}$; ovary, style and stigma not remarkably differentiated from each other; stigma capitate, slightly enlarged. Fruit a linear, spirally twisted capsule, c.5 cm long, c. $1.5 \mathrm{~mm}$ wide, glabrous. Seeds ellipsoid, $0.6 \times 0.15 \mathrm{~mm}$.

Distribution. China (Guangxi, Guizhou, Yunnan), Burma [Cambodia and Vietnam, see below].

Habitat and ecology. On limestone.

Proposed IUCN conservation assessment. Least Concern (LC). This species has been collected at several sites over a wide area and there are no major threats. 


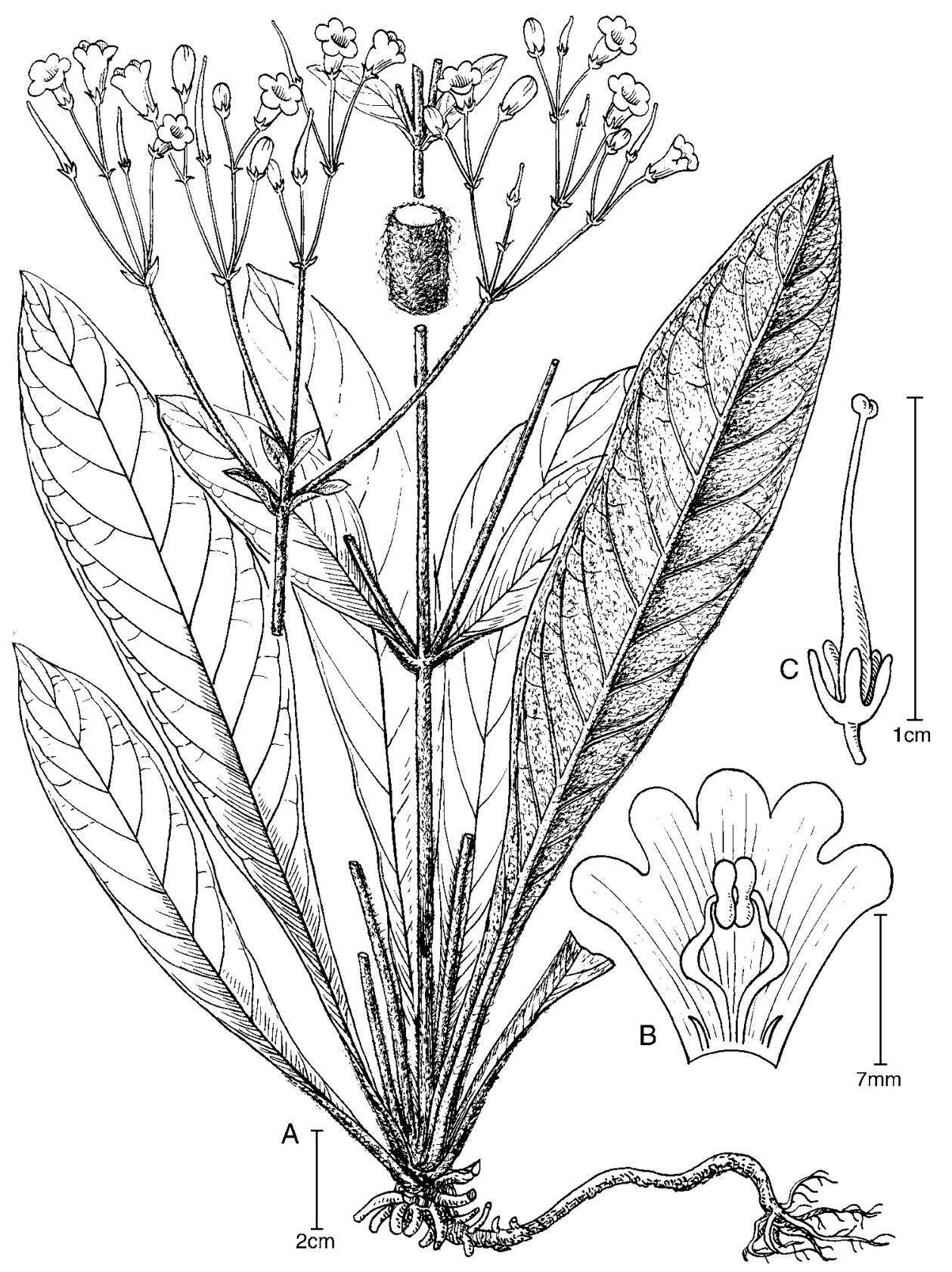

FIg. 19. Paraboea glutinosa (Hand.-Mazz.) K.Y.Pan. A, habit; B, corolla opened out; C, pistil and calyx. 
Additional specimens examined. Burma. Kyatoyin to Mogok [22 $\left.55^{\prime} \mathrm{N} 96^{\circ} 29^{\prime} \mathrm{E}\right]$, Ruby Mines District, 23 x 1912 (fr, fl), J.H. Lace 6273 (E).

China. Guangxi: (fl, fr), R.C. Ching 6590 (NY); (fl), Y.K. Li 1565 (IBSC); 23 vii 1937 (fl, fr), C. Wang 41202 (IBSC, photo US). Guizhou: 29 viii 1904 (fl, fr), J. Cavalerie 1783 (E, syntype of Boea martinii H.Lév.); 1908 (lv, fr), J. Cavalerie 7409 (E, K); 1100 m, 6 vii 1912 (fl),

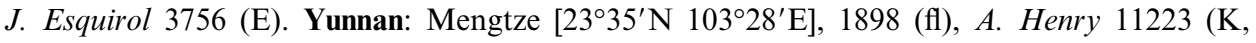
NY, US).

When he described Boea martinii Léveillé (1914) included two collections in his citation, here treated as representing two different species. Burtt (1984) lectotypified Boea martinii with Martin in herb. Bodinier 2378 and he continued to include the other material in Léveillé's citation [J. Cavalerie 1783 (E), from China: Guizhou, Pinfa, $\left.26^{\circ} 12^{\prime} \mathrm{N} 107^{\circ} 04^{\prime} \mathrm{E}\right]$ in this species along with the type of Boea glutinosa. However, there are two species in this group and the syntype of Boea martinii, $J$. Cavalerie 1783, belongs to the same species as the type of Boea glutinosa rather than to Boea martinii.

The two groups of plants now represented by Paraboea glutinosa and P. martinii are remarkably different. In the latter species the flowering stem elongates up to $20 \mathrm{~cm}$ long from the uppermost vegetative leaf to the first axillary cyme or paniclelet and the floral leaves are much smaller than the mature vegetative leaves. In the former species the flowering stem develops no elongated internodes before the first axillary cyme or paniclelet and the first (or most basal) cymes come from basal leaves. Furthermore, the floral leaves are not appreciably different in size and shape to the normal vegetative leaves.

Collections of this species from Guangxi and Guizhou have narrow elliptic leaves $>3$ times as long as wide with a long-attenuate base and without a distinct petiole. However, other collections currently included under this species name, collected from Yunnan (China) and Burma, have wider leaves $<2$ times as long as wide with a wide-cuneate base and a distinct petiole [A. Henry $11223(\mathrm{~K})$ and J.H. Lace 6273 $(\mathrm{E}, \mathrm{K})]$. They might represent an undescribed species but the current material is insufficient to establish this.

\section{2a. Paraboea aff. glutinosa, sp. nov.?}

Poilane 28717 and Poilane 16562 may be specimens of an undescribed species. It has the same inflorescence as that of Paraboea glutinosa, but the plant has an elongated stem rather than being rosulate and the leaves have a distinct reticulate venation. Although the available material is scarcely sufficient to justify a new name, the collection is described below for the convenience of recognising the same kind of plants.

Perennial caulescent herb; stem c.14 cm tall, $6 \mathrm{~mm}$ in diameter, internodes $1-2 \mathrm{~cm}$ long, with a brown matted indumentum which is later glabrescent. Leaves opposite, petiolate; petiole $3-8 \mathrm{~cm}$ long, with 2 narrow wings extending to the base and surrounding the node; blades thinly to thickly papery, ovate, $12-17 \times 5-8 \mathrm{~cm}$, apex 
with short acumen, base widely cuneate, margin entire, upper surface with some hairs when young and later glabrous, lower surface with a brown matted indumentum; veins smooth above, raised beneath, lateral veins 10-15 pairs, tertiary venation distinctly reticulate. Inflorescence a terminal panicle, glabrescent; flowering stem c. $30 \mathrm{~cm}$ long, with 2 cymes from each node, internodes up to $11 \mathrm{~cm}$ long, floral leaves much smaller than vegetative leaves, ovate, up to $1 \times 0.5 \mathrm{~cm}$, reducing in size upward; cymes $<15 \mathrm{~cm}$ long, many-flowered; peduncle bract scale-like, pedicel bract sepal-like; pedicel $0.6-1 \mathrm{~cm}$ long. Calyx persistent in infructescence, $2-3 \mathrm{~mm}$ long, 5-lobed, lobes narrow-ovate. Flower not seen. Fruit a linear spirally twisted capsule, $2.5-3.5 \mathrm{~cm}$ long. Seeds not seen.

Additional specimens examined. Cambodia. Kompong Chhnang: Phnom Chom, de Kg. Chnang, sol granitique, 1200 m, 20 i 1939 (fr), E. Poilane 28717 (E, P).

VIETnam. $8.2 \mathrm{~km}$ de la route de Phu Qui a Kebon, on rock, 3 viii 1929 (fr), E. Poilane 16562 (E, P).

\section{Paraboea graniticola Z.R.Xu, sp. nov.}

Paraboeae harrovianae (Craib) B.L.Burtt proxima sed planta caulescenta foliis valde majoribus calycibus glabris differt. - Type: [Vietnam], Dai Ding (Dai Dinh),

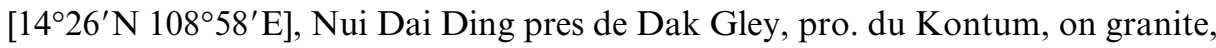
21 i 1947 (fr), E. Poilane 32819 (holo P; iso E, P).

Perennial caulescent herb; stem $0.6-1 \mathrm{~cm}$ thick; internodes $1-5 \mathrm{~cm}$ long, with a brownish-orange matted indumentum when young then glabrescent. Leaves opposite, petiolate; petiole 10-14 cm, with narrow wings on both sides, enlarged at the base and embracing the stem; blades ovate or wide-ovate, $10-25 \times 5.5-15 \mathrm{~cm}, 1.5$ times or less as long as wide, obtuse at the apex, rounded at the base, margin entire, glabrous (or glabrescent) above, with a brownish-orange matted indumentum beneath; veins smooth or obscure above, raised beneath, lateral veins 7-10 pairs, tertiary venation reticulate. Inflorescence subterminal, cymose, c. $50 \times 20 \mathrm{~cm}$ in fruit, glabrous, manyflowered; peduncle c. $30 \mathrm{~cm}$ long, c. $3 \mathrm{~mm}$ in diameter, peduncle bracts ovate, $6 \times$ $3 \mathrm{~mm}$; pedicel $0.5-1 \mathrm{~cm}$ long, pedicel bracts sepal-like. Flowers not seen. Calyx in fruit 2.5-3.5 mm long, 5-lobed, lobes narrow-ovate, c.4 times as long as wide. Fruit a linear capsule, c. $3-5 \mathrm{~cm}$ long, spirally twisted. Seeds not seen.

Distribution. Vietnam. Known only from the type.

Habitat and ecology. Unknown.

Proposed IUCN conservation assessment. Data Deficient (DD). Although this species is known only from the type it is recorded as having been collected from granite rather than limestone. As the threat to the habitat is unknown a conservation assessment cannot be given.

This species is similar to Paraboea harroviana with which it shares a similar inflorescence. However, the leaves are much larger and the calyx is glabrous. 
34. Paraboea guilinensis L.Xu \& Y.G.Wei, Acta Phytotax. Sin. 42(4): 380 (2004). - Type: China, Guangxi, Guilin, Dabuxiang, 20 iv 1995, Y.G. Wei \& S.H. Zhong 95-14 (holo IBK; iso IBK).

Perennial short caulescent herb; stem 2-10 cm long, 4-5 mm wide. Leaves petiolate; petiole 1.4-3 cm long, brownish lanate; blade coriaceous, obovate-elliptic or elliptic, $2.8-5.8 \times 1.5-2.2 \mathrm{~cm}$, apex rounded, base rounded to broadly cuneate, margin involute, denticulate, greyish-lanate above, later subglabrous, with a dense matted indumentum beneath; venation impressed above, raised beneath, 5-6 pairs of lateral veins. Inflorescence axillary, cymose, 3-5-flowered; peduncle $3.5-6.5 \mathrm{~cm}$ long, glabrous; pedicels filiform, 10-20 mm long. Calyx 5-lobed to the base, lobes linear-lanceolate, 1.8-2.1 $\times 0.5-0.7 \mathrm{~mm}$, glabrous. Corolla bluish-purple, glabrous, 13-15 mm long, c.10 $\mathrm{mm}$ in diameter; tube 6-8 $\mathrm{mm}$ long, limb 2-lipped; upper lip 2lobed, lobes oblong, 3.5-4.5 $\times 2-3 \mathrm{~mm}$, lower lip 3-lobed, lobes suborbicular, 5-7 $\times$ 6-7.5 mm. Stamens inserted at $0.7 \mathrm{~mm}$ from the corolla base; filaments $4.5-5 \mathrm{~mm}$ long; anthers ellipsoid, $2.5 \times 1.5 \mathrm{~mm}$, yellow; staminodes $1.2 \mathrm{~mm}$ long. Gynoecium 6-6.5 mm long, glabrous; ovary linear, $2.8-3 \mathrm{~mm}$ long, $0.4 \mathrm{~mm}$ wide at base; style $3.2-3.5 \mathrm{~mm}$ long. Fruit linear, not twisted, 2-2.8 cm long, 2-2.4 $\mathrm{mm}$ wide, glabrous.

Distribution. China: Guangxi. Known only from the type.

Habitat and ecology. On limestone.

Proposed IUCN conservation assessment. Critically Endangered (CR B1ab(ii,iii,v)) see conservation assessment section in introduction.

35. Paraboea hainanensis (Chun) B.L.Burtt, Notes Roy. Bot. Gard. Edinburgh 41: 429 (1984). - Boea hainanensis Chun, Flora Hainanica 3: 526, 588 (1974). - Type: China, Hainan, Yaichow, on moist shaded rocks along streams in mountains [18 $08^{\prime} \mathrm{N} 109^{\circ} 30^{\prime} \mathrm{E}$ ], 24 ix 1933 (fl), H. Y. Liang 63102 (holo IBSC; iso E, NY). Fig. 20.

Rosulate perennial herb with stout roots. Leaves sessile, thick-coriaceous, normally narrow-obovate, rarely narrow-elliptic, $8-10 \times 2.5-3.5 \mathrm{~cm}, 2.5-4$ times as long as wide, apex normally obtuse, rarely obtuse-acute, base attenuate, margin more or less crenulate, upper surface glabrous, lower surface with a reddish brown rather appressed matted indumentum, veins smooth or faintly depressed above, raised beneath. Inflorescence axillary, cymose, longer than the leaves, lax, several-flowered, $15-30 \mathrm{~cm}$ long, with the same indumentum as that on the lower leaf surface when young and glabrescent when older; peduncle relatively slender, c.12-24 cm long, bracts very small, narrow-ovate, $3 \times 0.5 \mathrm{~mm}$; pedicels $15-30 \mathrm{~mm}$ long, more or less glandular-pubescent. Calyx campanulate, 5-lobed to the base, lobes ovate, c. $2 \times$ $0.8 \mathrm{~mm}$, glabrous. Corolla various shades of blue, c. $12 \mathrm{~mm}$ long, $13 \mathrm{~mm}$ in diameter; tube c. $4 \mathrm{~mm}$ long, $5 \mathrm{~mm}$ in diameter at the throat, limb 2-lipped; upper lip 2-lobed, lobes ovate, c. $6 \times 5 \mathrm{~mm}$, lower lip c. $1 \mathrm{~cm}$ long, $1.3 \mathrm{~cm}$ wide, 3-lobed, middle lobe 


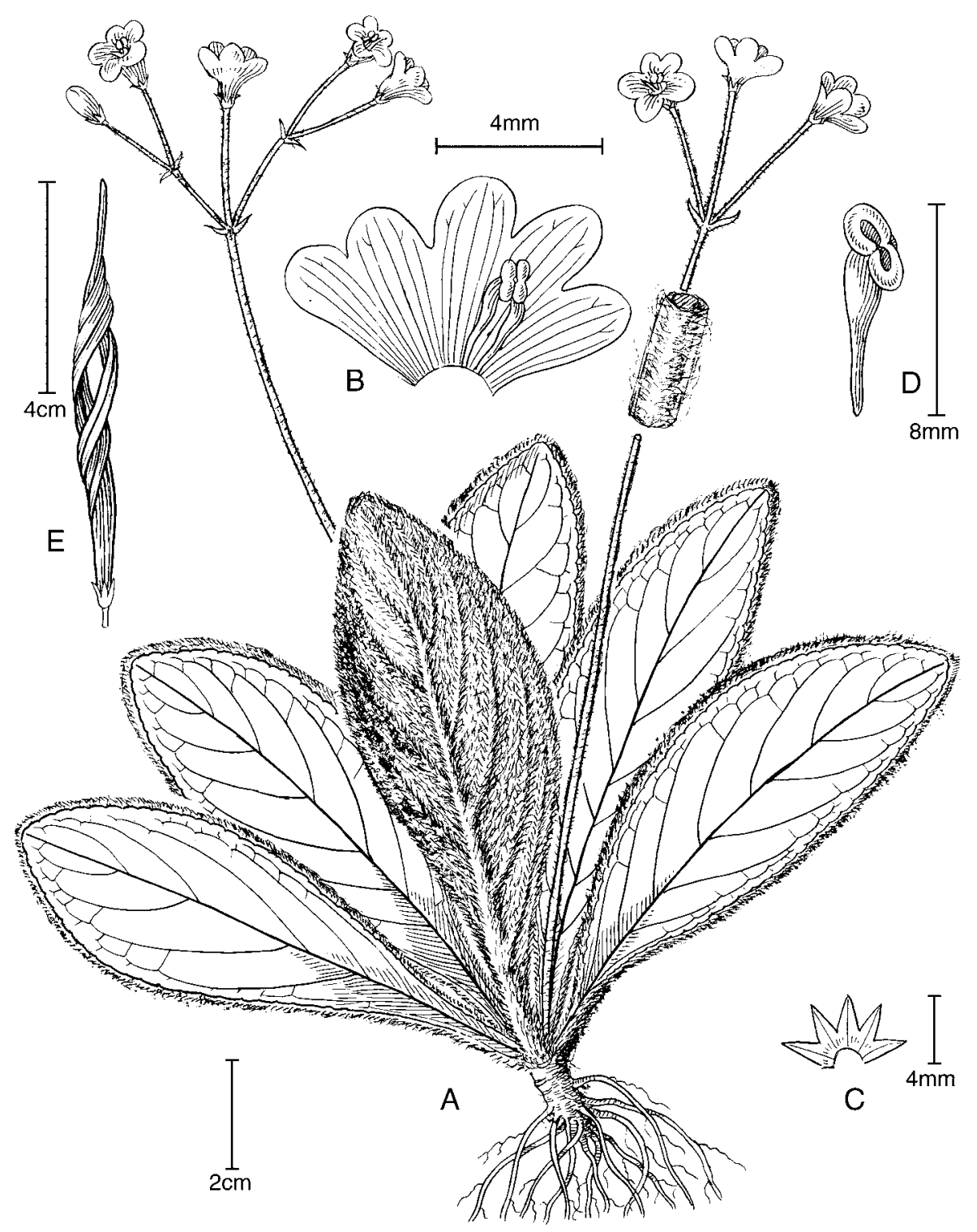

FIg. 20. Paraboea hainanensis (Chun) B.L.Burtt. A, habit; B, corolla opened out; C, calyx opened out; D, stamen; E, fruit.

ovate, c. $5 \times 5 \mathrm{~mm}$, lateral lobes wide-ovate, c. $4 \times 5 \mathrm{~mm}$. Anthers transversely ellipsoid, c. $1.2 \times 2.8 \mathrm{~mm}$, coherent with each other at the apex, opening in the centre of the anther locules, dorsifixed, apex pointing towards the gynoecium; filaments inserted at c. $1 \mathrm{~mm}$ from the corolla base with a free part c. $6 \mathrm{~mm}$ long, swollen in the upper part to c. $1.5 \mathrm{~mm}$ wide; staminode very tiny, only 1 observed. Gynoecium c. $9 \mathrm{~mm}$ long, $1 \mathrm{~mm}$ wide at the ovary base; ovary without a distinguishable boundary 
between the ovary and the style, with some minute pubescence; stigma much wider than style, seemingly tomentose. Fruit a linear capsule, $3-4.5 \mathrm{~cm}$ long, c. $2 \mathrm{~mm}$ in diameter, glabrous, spirally twisted but weakly so. Seeds ellipsoid, $0.4 \times 0.5 \mathrm{~mm}$.

Distribution. China: Hainan.

Habitat and ecology. Reported as occurring on acid soil.

Proposed IUCN conservation assessment. Endangered (EN B1ab(ii,iii,v)). This species is only known from two nearby localities. Although the extent of occurrence is clearly $<100 \mathrm{~km}^{2}$, which would justify a Critically Endangered category, the two localities reduces the threat somewhat and Endangered is a more suitable category.

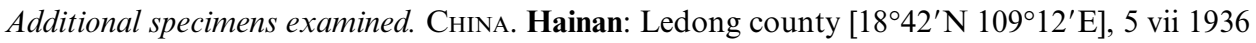
(fl), S.K. Lau 27407 (A, IBSC); Loktung [ = Ledong, i.e. Le4Dong1], 27 vii 1963 (fr), S. K. Lau 27597 (A).

In Paraboea hainanensis the matted indumentum on the lower leaf surface is very thick and appressed with a reddish-brown colour. This is the same as is found in Oreocharis Benth. The hairs are long and thick, straight, unbranched, and intermixed with very fine curved interwoven ones. The extremely swollen filament is another distinct character. The dehiscence and coherence of the anthers are the same as that found in Paraboea brunnescens, but the gynoecium without a clear boundary between the style and the ovary is similar to that found in P. dictyoneura. In overall morphology this species is most similar to Paraboea dictyoneura.

36. Paraboea halongensis Kiew \& T.H.Nguyên, Gard. Bull. Singapore 52(1): 195 (2000). - Type: Vietnam, Ha Long Bay, Nguyen Tien Hiep \& Ruth Kiew NTH4055 (holo $\mathrm{HN}$; iso BM, E, K, LE, MO, SING).

Perennial caulescent herb, branching near base; stems with a matted indumentum, 4.5-18 cm long, c. $2 \mathrm{~mm}$ wide. Leaves opposite, petiolate; petiole (6-)12-17 mm long, with a greyish matted indumentum and scattered darker larger hairs; blade lanceolate to obovate, $1.7-4.3 \times 0.6-2.5 \mathrm{~cm}$, apex acute, base cuneate to rounded, with short pale stiff hairs above, with a greyish matted indumentum and scattered darker larger hairs, especially on venation; lateral veins 4-5 pairs, impressed above, raised beneath. Inflorescence subterminal, cymose; c. 3 cymes from the axils below the terminal bud, 4-6.6(-14) $\mathrm{cm}$ long, branches monocarpic, glabrous; peduncle 2.9-3.7(-10) cm long, c. $1 \mathrm{~mm}$ wide, bracts c. $12 \times 6 \mathrm{~mm}$, stalk c. $4 \mathrm{~mm}$ long; pedicels 3-9 mm long. Calyx 5-lobed to the base, lobes oblong, c. $2 \times$ $1 \mathrm{~mm}$, apex rounded. Corolla white, $8 \mathrm{~mm}$ long, 7-8 $\mathrm{mm}$ in diameter; tube slightly saccate at base; lobes all similar, rounded, c. $2 \times 4-5 \mathrm{~mm}$. Anthers white, c. $15 \mathrm{~mm}$ long; filaments pale rosy-purple, c.3-4 mm long. Gynoecium white; ovary c.5 mm long; style straight, c.3 mm long; stigma capitate. Fruit twisted, 1.2-2 cm long, $1-1.5 \mathrm{~mm}$ in diameter.

Distribution. Vietnam: Quang Ninh. Known only from the type. 
Habitat and ecology. 'In soil filled cracks in bare, exposed rocks near the summit of limestone islands' (Nguyen \& Kiew, 2000).

Proposed IUCN conservation assessment. Least Concern (LC). Although the species is known only from the type collection, Ha Long Bay is an extensive and wellprotected limestone site.

37. Paraboea harroviana (Craib) Z.R.Xu, comb. nov. - Boea harroviana Craib, Bull. Misc. Inform. Kew 1926: 172 (1926). - Type: Thailand, Chiangmai, Me Ping Rapids, Keng Soi [18 $\left.12^{\prime} \mathrm{N} 98^{\circ} 34^{\prime} \mathrm{E}\right], 300$ m, (fr), A.F.G. Kerr 4629 (lecto K, designated by Burtt (1984: 427); iso ABD).

\section{7a. Paraboea harroviana var. harroviana}

Perennial herb with a short stem. Leaves opposite, congested, petiolate; petiole c.1-5 cm long, with a greyish to brownish matted indumentum; blades \pm elliptic, oblique, c.6-15 × 3-6 cm, c.2.5-5 times as long as wide, apex acute, base cuneate and oblique, margin \pm shallowly serrate, upper surface glabrous, lower surface with a greyish to brownish matted indumentum; veins smooth above, raised beneath, lateral veins c.10-12 pairs, \pm curved-ascending, tertiary venation \pm reticulate. Inflorescence subterminal, cymose; cymes usually 2, sometimes 1 , 3 or 4 , from the axils below the apical bud, c. $17-50 \mathrm{~cm}$ long, 5-8 cm wide, manyflowered, with a greyish to brownish matted indumentum throughout except on the corolla and the parts inside the corolla; peduncle c.10-20 cm long, quite robust, with two distinct bracts of various sizes; pedicels c.10 mm long, with bracts sepal-like. Calyx c.2.5-4 mm long, 5-lobed to the base, lobes narrowly ovate, c. $2.5 \times 0.7 \mathrm{~mm}$, with a matted indumentum outside, glabrous inside. Corolla blue, c. $8.5 \mathrm{~mm}$ long, $10 \mathrm{~mm}$ across when open; tube c. $3 \mathrm{~mm}$ long, limb not distinctly 2-lipped; upper lip with 2 lobes, lower lip with 3 lobes, 5 lobes of similar shape and size except the middle lobe of the lower lip which is slightly larger, all widely ovate, c. $2.5 \mathrm{~mm} \times 3.5 \mathrm{~mm}$, glabrous. Anthers reniform, c. $1.5 \times 3 \mathrm{~mm}$, coherent with each other, opening towards the top of the anther, basifixed; filaments inserted at c. $1.5 \mathrm{~mm}$ from the corolla base with a free part c. $2.5 \mathrm{~mm}$ long; staminodes 3; 3 triangular glands inserted at the corolla throat. Gynoecium longer than the corolla, c. $1.2 \mathrm{~mm}$ wide at the ovary base; style very short, curved towards the anthers; stigma not enlarged but extremely oblique. Fruit very slender, c. $4 \mathrm{~cm}$ long, $1 \mathrm{~mm}$ wide, spirally twisted, glabrous. Seeds ellipsoid, c. $4 \times$ $1.5 \mathrm{~mm}$.

Distribution. Cambodia, Thailand and Vietnam.

Habitat and ecology. On limestone.

Proposed IUCN conservation assessment. Least Concern (LC). This species has been collected at many sites over a wide area and there are no major threats. 
Additional specimens examined. Cambodia. Pursat: Mont de Pursat, 1875 (fl), Harmand $462(\mathrm{P})$.

Thailand. Chanthaburi: [= Chantaboon] [12 $\left.40^{\prime} \mathrm{N} 102^{\circ} 10^{\prime} \mathrm{E}\right], 1936$ (fl, fr), A. Vesterdal 7 (C). Kanchanaburi: Kwae Noi River Basin, near Neeckey, near Wangka $\left[14^{\circ} 15^{\prime} \mathrm{N} 99^{\circ} 10^{\prime} \mathrm{E}\right]$, 150 m, 17 v 1946 (fl), G. Den Hoed 580 (A, L); between Huay Ban Kao and Kritee $\left[15^{\circ} 00^{\prime} \mathrm{N}\right.$ 9850'E], 500 m, 4 vii 1973 (fl), R. Geesink \& Phengkhlai 6084 (AAU, BKF, C, E, L, P);

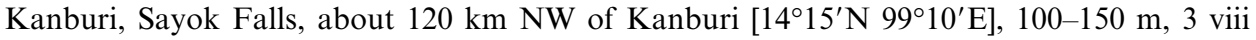
1946 (fl), A.J.G.H. Kostermans 1451 (A, L, P, US); Sangklaburi District, Toong Yai Naresuan Wildlife Reserve, Lai Wo, Ban Saneh Pawng area, 300 m, 11 x 1993, Maxwell 93-1223 (L). Loei: Phu Krading [16 $\left.58^{\prime} \mathrm{N} 101^{\circ} 57^{\prime} \mathrm{E}\right], 21$ viii 1949 (fl), D. Bunpheng 371 (BKF); Phu Krading, Sam Khae, 1100 m, 16 vii 1953 (fr), D. Bunpheng 663 (ABD, BKF); Phu Krading, near stream, 15 x 1967 (fl), Prayad 1033 (BKF); Phu Krading, 1 ix 1969 (fl), S.P. et al. 17 (BKF, L); Amphoe [= District] Phu Krading, 15 x 1967 (fl), P. Sangkhachand 1033 (L); Phu Luang [17²9'N 101³5'E], 17 ix 1966 (fr), S. Phusomsaeng \& Bunchuai 44 (BKF); Phu Luang Wildlife Reserve, Nam Tok to Pa Paw trail, 29 ix 1990, P. Chantaranothai et al. 90/442 (K); interior of Nam Thop, on eastern slope of Phu Luang, 400-850 m, 7 xii 1965 (fr),

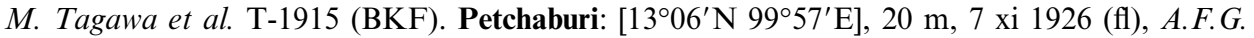
Kerr 11067 (A, ABD, L); Khao Hong, 10 iii 1965 (fr), Sakol 486 (BKF). Prachuap Khiri Khan: Kong Wan [12 $02^{\prime} \mathrm{N}$ 99 55'E], $20 \times 1964$ (fl), C. Chermsirivathana 110 (BKF); Ban Pu, Kuiburi $\left[12^{\circ} 15^{\prime} \mathrm{N} 99^{\circ} 55^{\prime} \mathrm{E}\right], 25$ xi 1964 (fl), Adisai 972 (BKF); Khao Nam Tok, west of

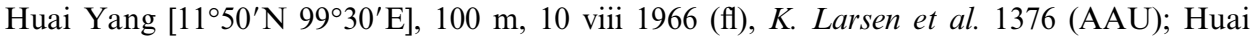
Yang, 4 x 1930 (fl), Put 3199 (ABD, K); Huay Yang National Park, Bua Sawan waterfall area, $11^{\circ} 40^{\prime} \mathrm{N} 99^{\circ} 36^{\prime} \mathrm{E}, 320 \mathrm{~m}, 26$ viii 2002, D.J. Middleton et al. 1356 (A, BKF). Ratchaburi: Khao

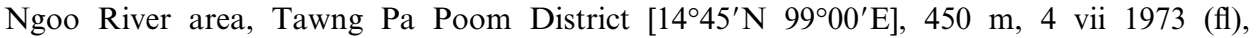
J.F. Maxwell 73-103 (AAU, BK, BKF); Huay Lum Khao Ngoo, Si Swat District, 15 vii

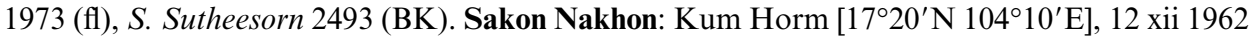

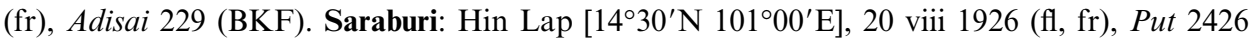
(ABD, K).

Vietnam. Ba Ria-Vung Tau: Ile Poulo Condor [0841'N 106 $37^{\circ}$ E], (fr), Harmand s.n. (P).

Burtt (1984) treated this specific name as a synonym of Paraboea dictyoneura (Hance) B.L.Burtt. However, Paraboea harroviana has subterminal cymes, which results in monocarpic branches or individuals due to the terminal bud ceasing to grow after a flowering season, while Paraboea dictyoneura has true axillary cymes from rosulate leaves and the terminal bud continues to grow after the flowering season. Also, this species has 3 glands inside the corolla throat and a very oblique stigma which distinguish it from Paraboea dictyoneura (no glands; capitate stigma). This species belongs to a group of species related to Paraboea cochinchinensis, $P$. argentea and $P$. pubicorolla that have subterminal inflorescences and very oblique stigmas.

Several specimens collected from southwest Thailand (Kanchanaburi Province), R. Geesink \& C. Phengkhlai 6084, S. Sutheesorn 2493 and A.J.G. H. Kostermans 1451, are somewhat different from the typical specimens in their much longer and larger inflorescences but are otherwise unremarkable.

37b. Paraboea harroviana var. ovata Z.R.Xu, var. nov.

Paraboeae harrovianae var. harrovianae proxima, sed foliis ovatis at extremum rotundis differt. - Type: Thailand, Phetchaburi Province, Maha Sohm Nah Rahm 
Temple area $\left[17^{\circ} 00^{\prime} \mathrm{N} 99^{\circ} 35^{\prime} \mathrm{E}\right]$, overgrown temple compound, rocky outcrops in a hardwood forest, corolla deep blue, 22 viii 1971 (fl), J.F. Maxwell 71-503 (holo $\mathrm{BK}$; iso AAU).

Boea treubii auct. non Forbes: Pellegrin in Lecomte, Fl. Indo-Chine 4: 544 (1930).

This new variety differs from the type variety in the rounded leaf apex (rather than acuminate or acute) and the ovate leaf blades (vs. more or less obovate). In general, Paraboea harroviana var. harroviana has much narrower leaf blades, c.2.5-5 times as long as wide, with an oblique base, and Paraboea harroviana var. ovata has wider leaf blades, c.1.5-2.5 times as long as wide, without an oblique base.

Distribution. Thailand and Vietnam.

Habitat and ecology. Unknown.

Proposed IUCN conservation assessment. Vulnerable (VU D2). This variety is currently only known from three independent collections: two from Vietnam and one from Thailand. As it is currently known from so few localities, and as limestone areas in Thailand and Vietnam are often exploited for cement or subject to fires from surrounding agricultural land, it should be considered Vulnerable.

Additional specimens examined. Vietnam. Expedition du Dr. Harmand en Indo-Chine 187577, Delta du Me-Khong, Nui Cam $\left[10^{\circ} 20^{\prime} \mathrm{N} 106^{\circ} 40^{\prime} \mathrm{E}\right]$, vi 1876 (fl), Harmand 547 (P). Dong Nai: Baria, Mt. Dinh $\left[10^{\circ} 32^{\prime} \mathrm{N} 107^{\circ} 09^{\prime} \mathrm{E}\right.$ ], delta du Mekong [Baria, $10^{\circ} 20^{\prime} \mathrm{N} 106^{\circ} 40^{\prime} \mathrm{E}$ ], vii 1867 (fl, fr), H.L. Pierre 4538 (A, E, GH, K, NY, P, UC, US, W).

38. Paraboea havilandii (Rid1.) B.L.Burtt, Notes Roy. Bot. Gard. Edinburgh 41: 429 (1984). - Boea havilandii Ridl., J. Straits Branch Roy. Asiat. Soc. 44: 73 (1905).

- Type: Sarawak, First Division, Gunung Braang, G.D. Haviland 641 (lecto K, designated by Burtt (1984: 429); iso SAR?, SING). Fig. 21.

Boea brettiana W.W.Sm., Notes Roy. Bot. Gard. Edinburgh 8: 319 (1915). - Type:

Sarawak, near Sudan, Native Collector 14 (lecto E, designated by Burtt (1984: 430); iso E).

Perennial caulescent subshrub, some plants monocarpic; stem up to $2 \mathrm{~m}$ tall, $1.5(-2) \mathrm{cm}$ in diameter; internodes quite short, normally $1-2 \mathrm{~cm}$ long, in the flowering plant the uppermost vegetative internode elongated up to $8 \mathrm{~cm}$ long, with a white or greyish orange matted indumentum when young, later becoming darker or paler. Leaves in whorls of 4, those from a single year often congested, sessile, more or less narrowly obovate-oblong, heterophyllous, smaller ones c.5$13 \times 1-2.5 \mathrm{~cm}$ and larger ones c. $18-30 \times 3-5.5 \mathrm{~cm}, \mathrm{c} .4-9$ times as long as wide, apex obtuse, base almost half as wide as the widest part of the leaf, margin entire or indistinctly serrulate, upper surface with a dense pubescence with some arachnoid hairs that later shed off, lower surface with a white matted indumentum that 


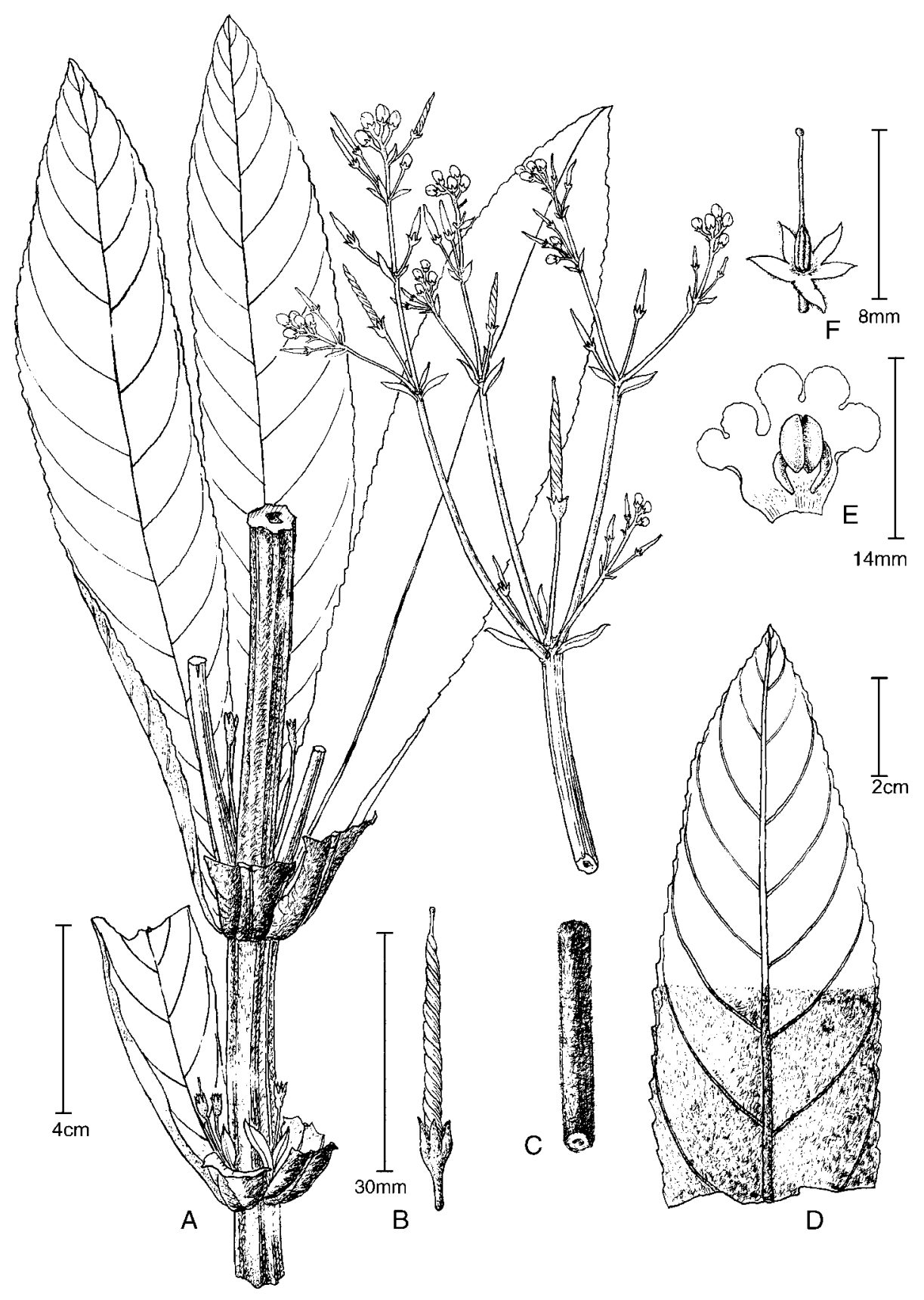

FIG. 21. Paraboea havilandii (Ridl.) B.L.Burtt. A, habit; B, fruit; C, section of peduncle; D, part of leaf; E, corolla opened out; F, pistil and calyx. 
changes colour to yellow-orange on the veins; veins smooth above except for the slightly prominent midrib, raised beneath, lateral veins sparse (sometimes obscure), 6-20 pairs, 1-2.5 cm apart, tertiary venation invisible. Inflorescence terminal, paniculate, with a white or greyish matted indumentum except on the flower; flowering stem long, (20-)70 cm long, the lowest internodes up to $20 \mathrm{~cm}$ long, floral leaves slightly smaller than the vegetative leaves, in some cases quite a lot smaller, 4 cymes from each node; cymes short or long, $12-40 \mathrm{~cm}$ long, peduncle bracts narrow-ovate, up to $10 \times 3 \mathrm{~mm}$, pedicel bracts sepal-like; pedicels 2-20 mm long. Calyx 2-3 mm long, 5-lobed, lobes ovate, with a matted indumentum outside, glabrous inside. Corolla light purple, purplish white, or pale lilac, c. $1 \mathrm{~cm}$ long, $1.2 \mathrm{~cm}$ across when fully open; tube c. $2.5 \mathrm{~mm}$ long, limb 2-lipped; upper lip $5 \mathrm{~mm}$ long, 2-lobed, lobes wide-ovate, c. $4 \times 4.5 \mathrm{~mm}$, lower lip c.8.5 mm long, with 3 lobes, middle lobe obovate, c. $4.5 \times 4.5 \mathrm{~mm}$, lateral lobes wide-ovate, c. $3.5 \times 5 \mathrm{~mm}$. Anthers transversely ellipsoid, c. $2.5 \times 5 \mathrm{~mm}$, coherent at the apex and the base, opening in the centre of the anther locules, apex turned towards the gynoecium, dorsifixed; filaments inserted at the corolla base with a free part c. $3 \mathrm{~mm}$ long, crenate at the margin. Gynoecium c.10 mm long; ovary ovoid, c. $1 \mathrm{~mm}$ wide; style c.7 $\mathrm{mm}$ long, narrower than the ovary; stigma capitate, larger than style. Fruit a linear or narrowly cylindric capsule, $1.5-2.5 \mathrm{~cm}$ long, 1-2 mm in diameter, glabrous, spirally twisted. Seeds narrowly ellipsoid, $0.9 \times 0.2 \mathrm{~mm}$.

Distribution. Malaysia: Sarawak.

Habitat and ecology. On limestone.

Proposed IUCN conservation assessment. Least Concern (LC). This species has been collected at several sites over a wide area and there are no major threats.

Additional specimens examined. Malaysia. Sarawak: s.l., 500 m, viii 1892 (fl), G.D. Haviland 1460 (K); Gunung Bar, Mambong, Penrissen, Kuching, 20 ii 1993 (fl, fr), P.C. Yii \& Rantai et al. S66020 (SAR); 1st Division: Bau limestone hills, Bukit Krian, 28 v 1972 (fl), J.A.R. Anderson S31973 (E, SAR); ibid., 29 iv 1955 (fl), W.M.A. Brooke 9904 (L); Bau (limestone) [014ㄴ $\left.\mathrm{N} 110^{\circ} 00^{\prime} \mathrm{E}\right]$, xii 1909 (fr), C.J. Brooks 1071 (L); Padawan District, Gunong Regu, 333 m, 6 v 1975 (fr, fl), B.L. Burtt 8088 (E); Bau District, Gunong Meraja (G Pungyang), S of Bidi, 17 v 1975 (fr, fl), B.L. Burtt 8152 (E); Bau, Seburan Mine, 15 v 1962 (fl), B.L. Burtt \& P.J.B. Woods 1832 (E); Gunong Staat, between Sarawak R and Bau, 333 m, 25 v 1962 (fr, fl), B.L. Burtt \& P.J.B. Woods 1929 (E); Bau, Bkt. Numpang, Taiton, $100 \mathrm{~m}$, (fr, fl), P. Chai \& Seng S22851 (K, L, SAR); Bidi Caves, S of Bau, 18 x 1929 (fl, fr), Clemens \& Clemens 7627 (NY); Bau, vii 1893 (fr), G.D. Haviland 11724 (K); Bau, Taiton Gold Mine, limestone hill, 25 v 1976 (fl), M. James et al. S37196 (E, K, L, SAR); Bau District, Bukit Tebong, 100 m, 11 viii 1970 (fr), P.F. Lehmann 395 (E); near Sudan, 2 xi 1914 (fr, fl), Native Collector s.n. (E, P); Suelan, 11 ii 1914 (fl, fr), Native Collector 14 (P); 1st Division, (fl, fr), Native Collector 1373 (A, K, P, US); Bau District, (fl), Native Collector 399 (L); ibid., ii-vi 1914 (fl, fr), Native Collector 2070 (P, US); 2nd Division: Bukit Sturib, next to Gunong Selabor, on base rocks of Kaoll below peak, 29 v 1975 (fr, lv), B.L. Burtt 8214 (E); G. Apin, Bau, 150 m, 7 xi 2001, Donny JG et al. SBC1367 (SAR). 
This species is similar to Paraboea treubii and $P$. verticillata. The three species are the most common among the tropical group that have a terminal paniculate inflorescence and leaves in whorls. Paraboea havilandii can be distinguished from the other two species by the heterophyllous leaves and the narrowly obovate-oblong leaf shape. In the other two species the leaves are not heterophyllous and are elliptic. The leaves of Paraboea havilandii are sessile, while the other two species have distinct petioles.

There is a specimen in SAR labelled Haviland 64 but from the same locality as the type material, Haviland 641. It is probably the same collection and, therefore, an isotype.

39. Paraboea incudicarpa B.L.Burtt, Notes Roy. Bot. Gard. Edinburgh 41: 430 (1984). - Type: Thailand, Tak Province, Pha Wo [16 $\left.52^{\prime} \mathrm{N} 99^{\circ} 10^{\prime} \mathrm{E}\right], 650 \mathrm{~m}$, herb on limestone rocks, common, 13 vii 1972 (fr), Smitinand \& Seidenfaden 11629 (holo E; iso BK). Fig. 22.

Herb, unbranched, up to $9 \mathrm{~cm}$ tall. Leaves oppositely congested on a stem with internodes $<5 \mathrm{~mm}$ long, petiolate; petiole c. $2-8 \mathrm{~cm}$ long; blades obovateelliptic, 5-17 $\times 3-11 \mathrm{~cm}$, c. 2 times as long as wide, apex with attenuate acumen, base widely cuneate or short-angustate, margin more or less crenate, upper surface glabrescent, lower surface with some thin whitish matted indumentum or glabrescent; veins smooth above, slightly raised beneath, lateral veins c. 9 pairs, tertiary venation obscure or invisible. Infructescence a subterminal cyme with many fruits congested in a short stout peduncle, making it appear capitate; peduncle 2-4 cm long; primary and secondary bracts similar in shape and size, numerous, widely ovate up to $1.5 \mathrm{~cm}$ long, $2 \mathrm{~cm}$ wide; pedicels rather stout, especially thickened at the apex, c.15 mm long. Flowers not seen. Fruit a short and thick triangular capsule, \pm incursiform, horizontally held on top of pedicel, not twisted, $0.8-1.1 \mathrm{~cm}$ long and $4-5 \mathrm{~mm}$ wide at the base, dehiscing along the upper suture only. Seeds narrowly ellipsoid, c. $0.5 \mathrm{~mm}$ long, with a long acumen on one end.

Distribution. Thailand.

Habitat and ecology. Unknown.

Proposed IUCN conservation assessment. Endangered (EN B1ab(ii,iii,v)) - for threats see conservation assessment section in introduction. This species is only known from two localities. The two localities are quite far apart so a status of Severely Fragmented may have been enough to push this into the higher category of CR. However, we are not sure if the extent of occurrence or area of occupancy is low enough to justify this. Further research is clearly necessary. This species was also included in Pooma (2005) as threatened in Thailand.

Additional specimen examined. Thailand. Kanchanaburi: Between Huay Ban Kao and Kritee, c. $15^{\circ} 00^{\prime} \mathrm{N} 98^{\circ} 50^{\prime} \mathrm{E}, 500 \mathrm{~m}, 4$ vii 1973, R. Geesink \& C. Phengkhlai 6105 (L). 


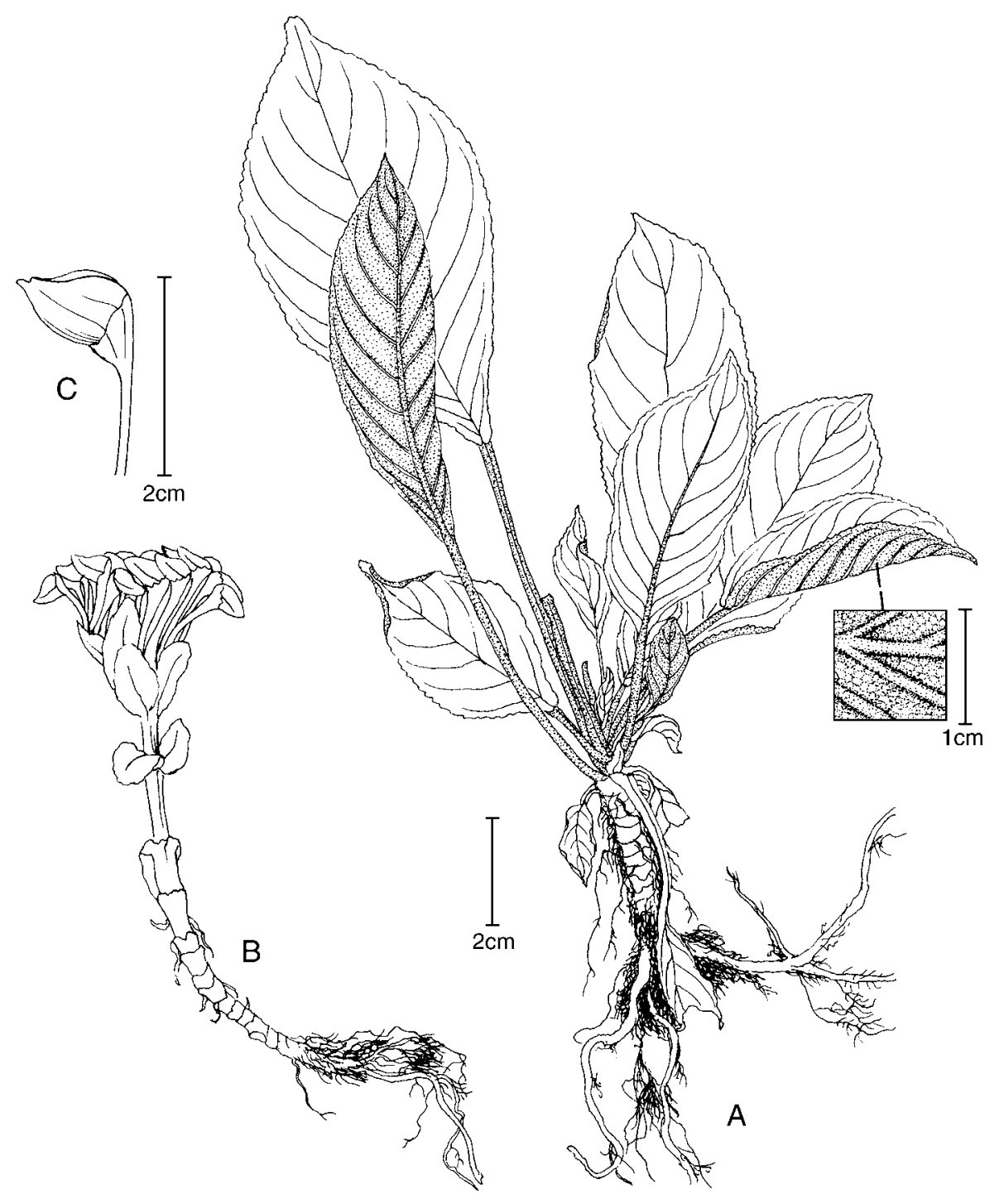

FIg. 22. Paraboea incudicarpa B.L.Burtt. A, habit; B, fruiting plant; C, fruit.

The morphology of this species is exceptional in Paraboea, as indicated by Burtt (1984). Even without flowers, the texture and indumentum of the leaves, the capsules and the infructescence of the type collection all present the generic characters of Hemiboea rather than Paraboea. In Hemiboea cymose inflorescences develop in subterminal axils (see Wang et al., 1990: 287, pl. 76, fig. 4). At the end of the flowering season the terminal bud between the two subterminal cymose inflorescences is aborted. Thus, the infructescence may look like a terminal cymose inflorescence but actually comprises two subterminal cymes opposite to each other. 
In some cases, the two subterminal fertile leaves that hold the two subterminal cymes may be dramatically reduced in size and join each other to form an auricle around the stem. This then makes the whole inflorescence look even more like a true terminal inflorescence with the auriculate subterminal fertile leaves appearing as terminal bracts embracing the whole inflorescence when young. However, inflorescences in Gesneriaceae are either a terminal panicle or an axillary cyme. Terminal cymes are not possible (see discussion about the inflorescence in the introduction of this paper). The subterminal cymose inflorescence is common throughout Hemiboea (Wang et al., 1990: 283-302), but is rare in Paraboea (P. sinensis presents a typical example). In the subterminal inflorescence of Hemiboea flowers are often congested at the top of a short peduncle, thereby having a capitate or umbellate appearance. In Paraboea the subterminal cymes often have distinct primary and secondary branches, thereby having a dichasial cymose appearance. In the case of Paraboea incudicarpa, the subterminal cymose inflorescence has the appearance of that in Hemiboea (see Wang et al., 1990: 287, pl. 76, fig. 4).

One might also study the capsule of this species. The normal Gesneriaceae ovary has 2 cells with 4 placentations. But in the ovary of Hemiboea, as is indicated by the name, only 1 cell with 2 placentations develops (see Wang et al., 1990: 287, pl. 76, fig. 10 ) and the other cell is generally sterile. When the capsule is mature the fertile cell is located on top of the sterile one resulting in the mature capsule opening only on one side, the upper suture, to release the seeds. In general, capsules of Hemiboea species are held in a spreading to horizontal position and the capsules are more or less curved into a sickle-shape with the inner curve facing upward. Thus, Hemiboea species can be recognised by their characteristic sickle-shaped capsules that open only along the upper suture. Although the sterile cell does not develop a rudiment can be seen in many Hemiboea species where a smaller tube bearing no seeds often exists below the developed cell, especially at the base of the capsule. In some rare cases the sterile cell may also partially develop and bear some seeds in the lower half of the cell. However, this cell never develops to the full length of the capsule. In Paraboea incudicarpa the capsule has a fully developed fertile cell on top of a partially developed sterile cell. The partially developed (sterile) cell is found at the base of the capsule. This is the capsule pattern of a Hemiboea species rather than of Paraboea species.

The flowers of Hemiboea and Paraboea are quite different. In Hemiboea the flowers are large, the corolla tube is long, and the lips of the limb are less well developed. In Paraboea the flowers are relatively smaller, the corolla tube is short, and the limb is relatively large and 2-lipped. Unfortunately the type specimen of Paraboea incudicarpa bears no flowers. We would suggest that Paraboea incudicarpa is rather a species of Hemiboea but we would rather await confirmation through the discovery of flowering material before transferring the name. This would make Hemiboea a new record for Thailand, a reasonable extension of the generic distribution given that it has about 20 species in southern China and adjacent countries. 
40. Paraboea kalimantanensis Z.R.Xu \& B.L.Burtt, Edinburgh J. Bot. $48: 3$ (1991). - Type: Borneo, Kalimantan Selatan, Batu Kumpai, Djaro, Muara Uja, exposed limestone rocks, 20 xi 1971 (fl, fr), J. Dransfield \& D. Saeradin 2255 (holo L).

Monocarpic caulescent subshrub; stem woody, $25 \mathrm{~cm}$ long, $6 \mathrm{~mm}$ in diameter, internodes very short, c.5 mm long, with a tawny matted indumentum. Leaves in whorls of 4, sessile, narrow-obovate, 5-11 $\times 1-2 \mathrm{~cm}$, apex obtuse, base cuneate, margin entire, upper surface densely pubescent, lower surface with a greyish-white matted indumentum except for the tawny veins; veins smooth above, raised beneath, lateral veins c.14 pairs, tertiary venation inconspicuous. Inflorescence terminal, paniculate, with a tawny matted indumentum except on the flower; flowering stem $45 \mathrm{~cm}$ long, the most basal internode $\mathrm{c} .15 \mathrm{~cm}$ long, floral leaves much smaller than vegetative leaves, up to $15 \times 5 \mathrm{~mm}$, reducing in size upward, 4 cymes from each node; cymes very short, $<5 \mathrm{~cm}$ long, few-flowered, peduncle bracts and pedicel bracts similar to each other, sepal-like, pedicel 3-5 mm long. Calyx c. $3 \mathrm{~mm}$ long, 5-lobed to the base, lobes narrow-ovate, with a tawny matted indumentum outside, glabrous inside. Corolla mauve, c. $3.5 \mathrm{~mm}$ long, c. $4 \mathrm{~mm}$ across; tube $1.5 \mathrm{~mm}$ long, limb 2lipped; upper lip 2-lobed, lobes ovate, $1.7 \times 2.5 \mathrm{~mm}$, lower lip 3-lobed, two lateral lobes ovate, $1.7 \times 2.5 \mathrm{~mm}$, middle lobe obovate, $1.7 \times 1.5 \mathrm{~mm}$. Anthers transversely ellipsoid, $2 \times 4 \mathrm{~mm}$, coherent with each other at the apex, apex turned towards the gynoecium, opening in the centre of the anther locules, dorsifixed by the filaments; filaments $1.7 \mathrm{~mm}$ long, slightly winged. Gynoecium c. $2.5 \mathrm{~mm}$ long, densely capitatepubescent; stigma capitate, not larger than style. Fruit a very long and delicate spirally twisted capsule, $2.5-3 \mathrm{~cm}$ long, $1 \mathrm{~mm}$ in diameter, densely capitate-pubescent when young, less so when mature. Seeds compressed, ovoid, $0.6 \times 0.2 \mathrm{~mm}$.

Distribution. Indonesia: Kalimantan.

Habitat and ecology. On limestone.

Proposed IUCN conservation assessment. Endangered (EN B1ab(ii,iii,v)) - for threats see conservation assessment section in introduction. This species is only known from two locations. The two localities are quite far apart so a status of Severely Fragmented may have been enough to push this into the higher category of CR. However, we are not sure if the extent of occurrence or area of occupancy is low enough to justify this. Further research is clearly necessary.

Additional specimen examined. Indonesia. Kalimantan: Central East Borneo, W. Koetai, Kombeng, 200 m, 22 xi 1925 (fl, fr), F.H. Endert 5171 (A, K, L).

This species is similar to Paraboea caerulescens (Ridl.) B.L.Burtt in sharing a dense capitate pubescence on the ovary and fruit. It is easily recognised by the very narrow panicle with very short lateral flowering branches.

41. Paraboea lanata (Ridl.) B.L.Burtt, Notes Roy. Bot. Gard. Edinburgh 41: 431 (1984). - Boea lanata Ridl., J. Linn. Soc., Bot. 32: 520 (1896). - Type: Peninsular 
Malaysia, Langkawi Islands, near Dayong Bunting, on almost bare rocks [06²0'N 9948'E], xi 1901 (fl, fr), C. Curtis 2569 (lecto SING, designated here; iso K). Fig. 23.

Perennial subshrub with a woody stem up to $50 \mathrm{~cm}$ long and $1.2 \mathrm{~cm}$ in diameter. Leaves in a rosette at the apex of the stem or just above ground, sessile, narrowly obovate, more or less irregular, 6-11 $\times 1-3.5 \mathrm{~cm}, 3-6$ times as long as wide, apex obtuse or acute, base attenuate, margin entire, upper surface with a pubescence under the cover of some arachnoid indumentum, lower surface with a white lanate indumentum (looser and thicker matted indumentum); veins smooth above, slightly raised beneath, lateral veins c.7 pairs, tertiary venation invisible. Inflorescence axillary, cymose, longer than the leaves, $10-30 \mathrm{~cm}$ long, c. $2-5 \mathrm{~cm}$ wide, several- to many-flowered, normally with $<20$ flowers; peduncle $5-15 \mathrm{~cm}$ long, at first with the same indumentum as that on the leaves and then glabrescent, peduncle bracts up to $1.5 \times 0.5 \mathrm{~cm}$; pedicels c.5-10 mm long, glandular pubescent, pedicel bracts sepallike. Calyx $2 \mathrm{~mm}$ long, 5-lobed to the base, ovate or narrowly so. Corolla magenta, c. $1 \mathrm{~cm}$ long, $1 \mathrm{~cm}$ across; tube $3.5 \mathrm{~mm}$ long, limb 2-lipped; upper lip 2-lobed, lobes widely ovate, c. $3 \times 3.5 \mathrm{~mm}$, lower lip c. $6 \mathrm{~mm}$ long, 3-lobed, middle lobe rounded, c. $3.5 \times 3.5 \mathrm{~mm}$, lateral lobes similar in size and shape. Anthers yellow, \pm oblong, c. $2.5 \times 3.5 \mathrm{~mm}$, coherent with each other at the apex and the inner surface, opening in the centre in a ' $\mathrm{V}$ ' shape with the apex pointing towards the gynoecium, basifixed; filaments inserted at $2.5 \mathrm{~mm}$ from the corolla base with a free part c. $2.5 \mathrm{~mm}$ long. Gynoecium c. $5 \mathrm{~mm}$ long, $1 \mathrm{~mm}$ wide at the ovary base; ovary with a dense glandular pubescence; stigma slightly larger than style. Fruit a linear capsule, c. $0.8 \mathrm{~cm}$ long, $1.5 \mathrm{~mm}$ in diameter, spirally twisted, with glandular pubescence. Seeds not seen.

Distribution. Peninsular Malaysia: Langkawi Islands. We are doubtful as to the label information on the Sumatra collection.

Habitat and ecology. In rock crevices or above ground on limestone.

Proposed IUCN conservation assessment. Least Concern (LC). This species has been collected at several sites, some of which are in protected areas, and there are no major threats.

Additional specimens examined. Indonesia. Sumatra: ix 1914 (fl), C.G. Matthew s.n. (K).

Malaysia. Kedah: Langkawi: Bumbon Kechil, [06 $\left.20^{\prime} \mathrm{N} 99^{\circ} 55^{\prime} \mathrm{E}\right], 166$ m, 10 xii 1960 (fr), Alphonso \& Samsuri A.88 (E), A.89 (E); P. Dayang Bunting [06¹3'N 9949'E], 29 iv 1962 (fr), B.L. Burtt \& P.J.B. Woods 1768 (E); Pulau Langkawi N end, Gua Cherita $\left[06^{\circ} 25^{\prime} \mathrm{N} 99^{\circ} 50^{\prime} \mathrm{E}\right]$, 30 iv 1962 (fr), B.L. Burtt \& P.J.B. Woods 1776 (E); Ayer Hangat, 2 v 1962 (fl), B.L. Burtt \& P.J.B. Woods 1805 (E); P. Langkawi shore SE of Kuah [06 $\left.19^{\prime} \mathrm{N} 99^{\circ} 52^{\prime} \mathrm{E}\right], 3$ v 1962 (fr, fl), B.L. Burtt \& P.J.B. Woods 1810 (E); Pulau Simpang Tiga Kechil, 10 xi 1979 (lv), B.C. Stone 14209 (L); P. Simpang Tiga Kechil, 10 xi 1979 (lv), B.C. Stone 14206 (A).

Burtt (1984) has a detailed description of the plant in the field. This species has a characteristic thick and silvery matted indumentum on both surfaces of the leaf. 


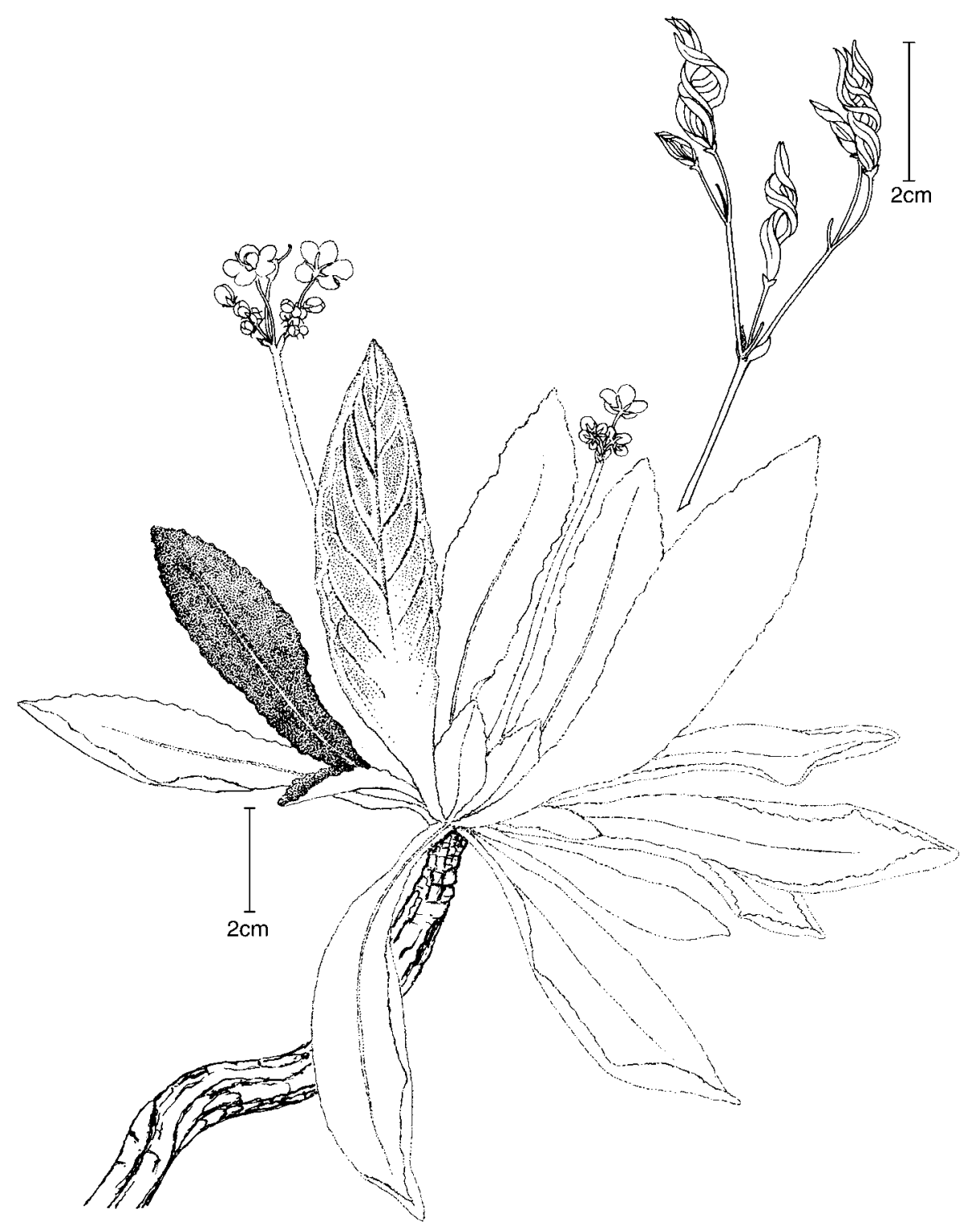

FIG. 23. Paraboea lanata (Ridl.) B.L.Burtt.

42. Paraboea lancifolia (Ridl.) B.L.Burtt, Notes Roy. Bot. Gard. Edinburgh 41: 431 (1984). - Boea lancifolia Ridl., Fl. Malay Penins. 2: 536 (1923). - Type: Thailand, Satun Province, Tarutao [06 50’ N 99³0'E], x 1888 (fl), C. Curtis 16010 (lecto K, designated by Burtt (1984: 431)). Fig. 24. 
Small shrub with a slender woody stem; stem c.5 mm in diameter, with a matted indumentum, brownish orange when young and later dark brown and glabrescent, internodes c. $1 \mathrm{~cm}$ long or shorter in the vegetative stem, but longer in the flowering stem. Leaves alternate, without a distinct petiole; blade narrowly ovate, $10-20 \times 1.5-$ $3.7 \mathrm{~cm}$, base attenuate and more or less extending along the petiole, apex acute, margin entire, upper surface with a tiny pubescence under some arachnoid covering, lower surface with a white to brownish-orange matted indumentum; veins obscure above, raised beneath, lateral veins 7-11 pairs, tertiary venation inconspicuous. Inflorescence a terminal panicle, with a matted indumentum throughout except for the glabrous flower; flowering stem c. $15-20 \mathrm{~cm}$ long with internodes $1.5-3 \mathrm{~cm}$ long, floral leaves similar to vegetative leaves; cymes (or secondary panicles) axillary from the flowering stem, short but bearing many flowers resulting in a tight cyme; peduncle c. $0.5-1.5 \mathrm{~cm}$ long, peduncle bracts (or primary bracts in a cyme) narrowly elliptic, c. $1 \mathrm{~cm}$ long; pedicels short, c. $5 \mathrm{~mm}$ long. Calyx very long, c. $8 \mathrm{~mm}$ long, 5lobed to the base, lobes very narrowly ovate, 5 times as long as wide with a distinct matted indumentum. Corolla glabrous, c. $6 \mathrm{~mm}$ long and $10 \mathrm{~mm}$ across; tube c.2.5 mm long, limb slightly 2-lipped; upper lip 2-lobed, lobes semi-rounded, c. $2.5 \times 5 \mathrm{~mm}$; the 3 lobes of the lower lip all wide-ovate but unequal in size with a middle lobe $2.5 \times 2 \mathrm{~mm}$ and two lateral lobes $2.5 \times 4 \mathrm{~mm}$. Anthers transversely ellipsoid, c. $1.5 \times 2.5 \mathrm{~mm}$, opening in the centre of the anther locules, loosely coherent at the apex and at the base, dorsifixed, apex pointing towards the gynoecium; filaments inserted at c. $2 \mathrm{~mm}$ from the corolla base, shorter than the gynoecium. Gynoecium c.6 mm long; ovary ovoid, c.1.2 mm wide; stigma slightly larger than style. Fruit a spirally twisted capsule, narrowly ovoid, c. $1 \mathrm{~cm}$ long, $2 \mathrm{~mm}$ in diameter, glabrous. Seeds ovoid, $0.5 \times 0.25 \mathrm{~mm}$.

Distribution. Peninsular Thailand: Tarutao Island.

Habitat and ecology. On limestone.

Proposed IUCN conservation assessment. Least Concern (LC). Although this species has been infrequently collected Tarutao is a national park and well protected.

Additional specimens examined. Thailand. Satun: Tarutao Island: limestone, near the sea [06 50' $\mathrm{N} 99^{\circ} 30^{\prime} \mathrm{E}$ ], 1 vii 1980 (fr, fl), Congdon 731 (A, AAU, E, PSU); ibid., 25 iv 1981 (fr), Congdon 1249 (A, E); limestone bluff near Crocodile Cave on Malacca Creek [NW side of the island], 5 xi 1979 (fl), Congdon 129 (AAU, E, PSU); c. $4 \mathrm{~km} \mathrm{~S}$ of the Northern Cape, $50 \mathrm{~m}, 11 \mathrm{i}$ 1986 (fr), Kurzweil 784 (WU).

Burtt (1984) cited '[Synonym: B. lanata auct. non Ridl.; Barnett in Fl. Siam. Enum. 3(3): 231 (1962) - quoad Rabil 301.]' under this species. However, Rabil 301 has since been described as Paraboea rabilii Z.R.Xu \& B.L.Burtt (see discussion under that species). Among the species that possess a terminal paniculate inflorescence, this species is the only one recorded with an alternate leaf arrangement. The relatively long calyx but short capsule is also remarkable for this species. In comparison, Paraboea suffruticosa has a similar habit, the same leaf arrangement 


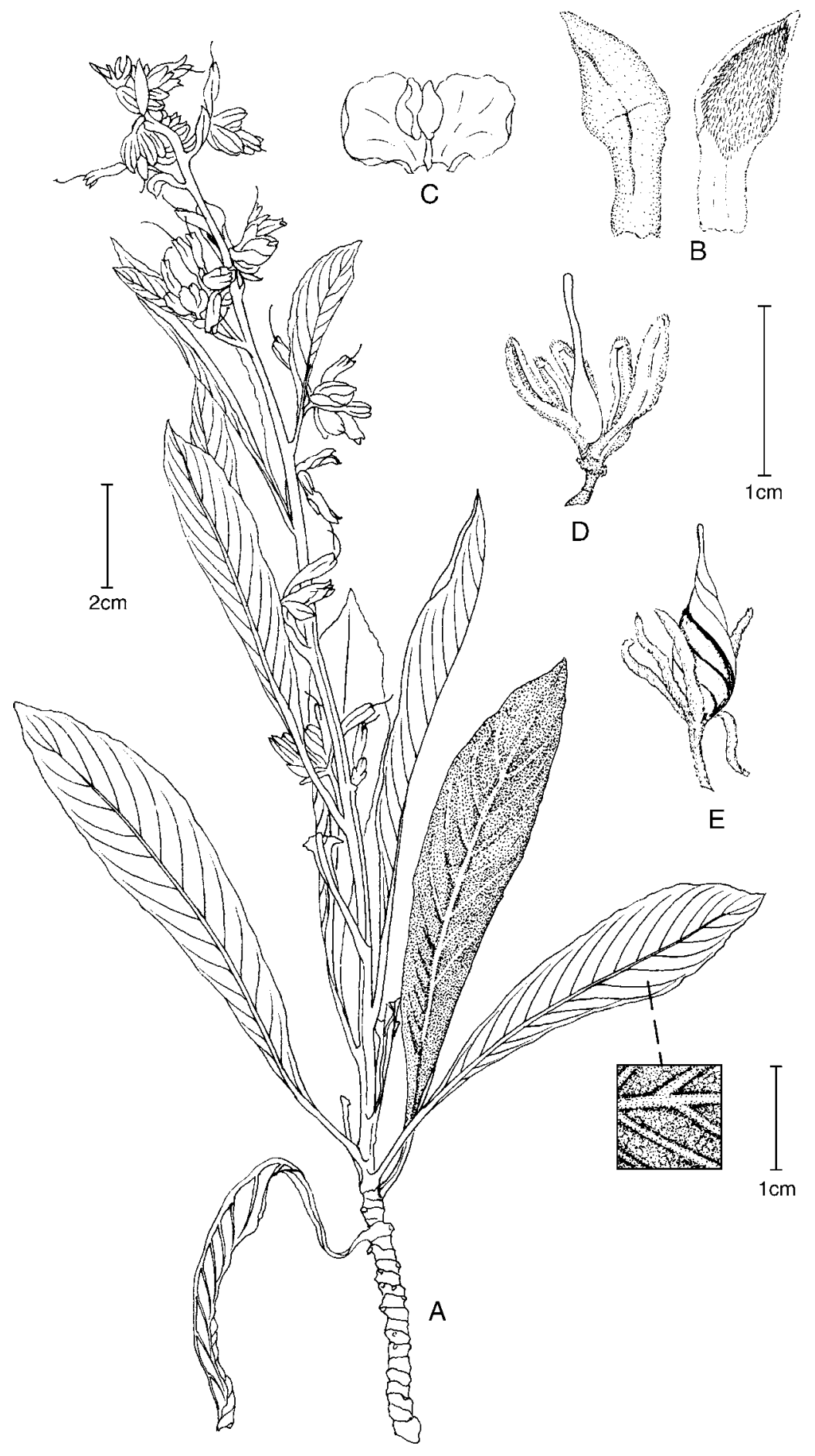

FIg. 24. Paraboea lancifolia (Ridl.) B.L.Burtt. A, habit; B, sepals; C, corolla opened out; D, pistil and calyx; E, fruit with persistent calyx. 
and a long calyx vs. short capsule, but it has axillary inflorescences rather than a terminal panicle.

43. Paraboea laxa Ridl., J. Straits Branch Roy. Asiat. Soc. 44: 70 (1905); Burtt, Notes Roy. Bot. Gard. Edinburgh 41: 431 (1984). - Type: Peninsular Malaysia, Kedah, Langkawi Islands, small islands opposite to Kuah [06 $\left.20^{\prime} \mathrm{N} 99^{\circ} 48^{\prime} \mathrm{E}\right]$, ix 1890 (fl, fr), C. Curtis 2571 (lecto SING, designated by Burtt (1984: 431); iso BM, K). Fig. 25.

Perennial herb, sometimes with a rhizome up to $7 \mathrm{~cm}$ long in crevices of rocks. Leaves congested in a rosette, base long-attenuate and so appearing petiolate for $2-$ $3 \mathrm{~cm}$ long; blades obovate when mature, (5-)8-20 × 3-7 cm, 2-5 times as long as wide, apex obtuse, margin shallowly crenate to deeply but remotely toothed, upper surface with a long pubescence, lower surface with a brownish matted indumentum; veins smooth above, raised beneath, lateral veins 5-7 pairs, tertiary venation sometimes conspicuous. Inflorescence an axillary cyme, with $>4$ bifurcations, much longer than the leaves, subordinate primary branches developed, 10-25 cm long, many-flowered and quite lax; peduncle 6-15 cm long, glabrescent, primary bracts narrowly ovate, up to $3 \mathrm{~mm}$ long, more or less hairy; pedicels 5-10 $\mathrm{mm}$ long, slender, with sepal-like bracts. Calyx campanulate, 5-lobed to the base, lobes ovate, c. $8 \times$ $0.6 \mathrm{~mm}$, outside glabrous, inside minutely pubescent. Corolla c. $12 \mathrm{~mm}$ across, $6 \mathrm{~mm}$ long; tube $2 \mathrm{~mm}$ long, limb 2-lipped; upper lip 2-lobed, lobes \pm rounded, $3 \times 5 \mathrm{~mm}$, lower lip c. $5.5 \times 8 \mathrm{~mm}$, 3-lobed, middle lobe $3 \times 4 \mathrm{~mm}$, lateral lobes similar to the upper lobes. Anthers transversely ellipsoid, c. $1 \times 2.5 \mathrm{~mm}$, opening in the centre of the anther locules, coherent with each other, dorsifixed; filaments $2.5 \mathrm{~mm}$ long, swelling or with wide wings in the middle part, inserted at the base of the corolla. Gynoecium $6.5 \mathrm{~mm}$ long; ovary c. $1.5 \times 1.2 \mathrm{~mm}$; style distinct, $0.2 \mathrm{~mm}$ long; stigma slightly larger than style. Fruit a linear non-twisted capsule, c. $1-2 \mathrm{~cm}$ long, $1 \mathrm{~mm}$ wide, glabrous, open at the upper suture (on very rare occasions the open valves may appear slightly twisted). Seeds ovoid, $0.4 \times 0.3 \mathrm{~mm}$, with a brown colour when dried.

Distribution. Peninsular Malaysia (Langkawi Island) and Thailand (see discussion below).

Habitat and ecology. Occurs on damp rocks (probably limestone according to the locality).

Proposed IUCN conservation assessment. Least Concern (LC). Although not all of Langkawi is protected the number of collections made would seem to suggest that the species is widespread on the island and there are no major threats. The collection from Thailand has not been taken into consideration for this assessment (see discussion below).

Additional specimens examined. Malaysia: Kedah: Langkawi, shore SE of Kuah, rocks above sea $\left[06^{\circ} 19^{\prime} \mathrm{N} 99^{\circ} 52^{\prime} \mathrm{E}\right], 3$ v 1962 (fr), B.L. Burtt \& P.J.B. Woods 1809 (E); Langkawi, main 


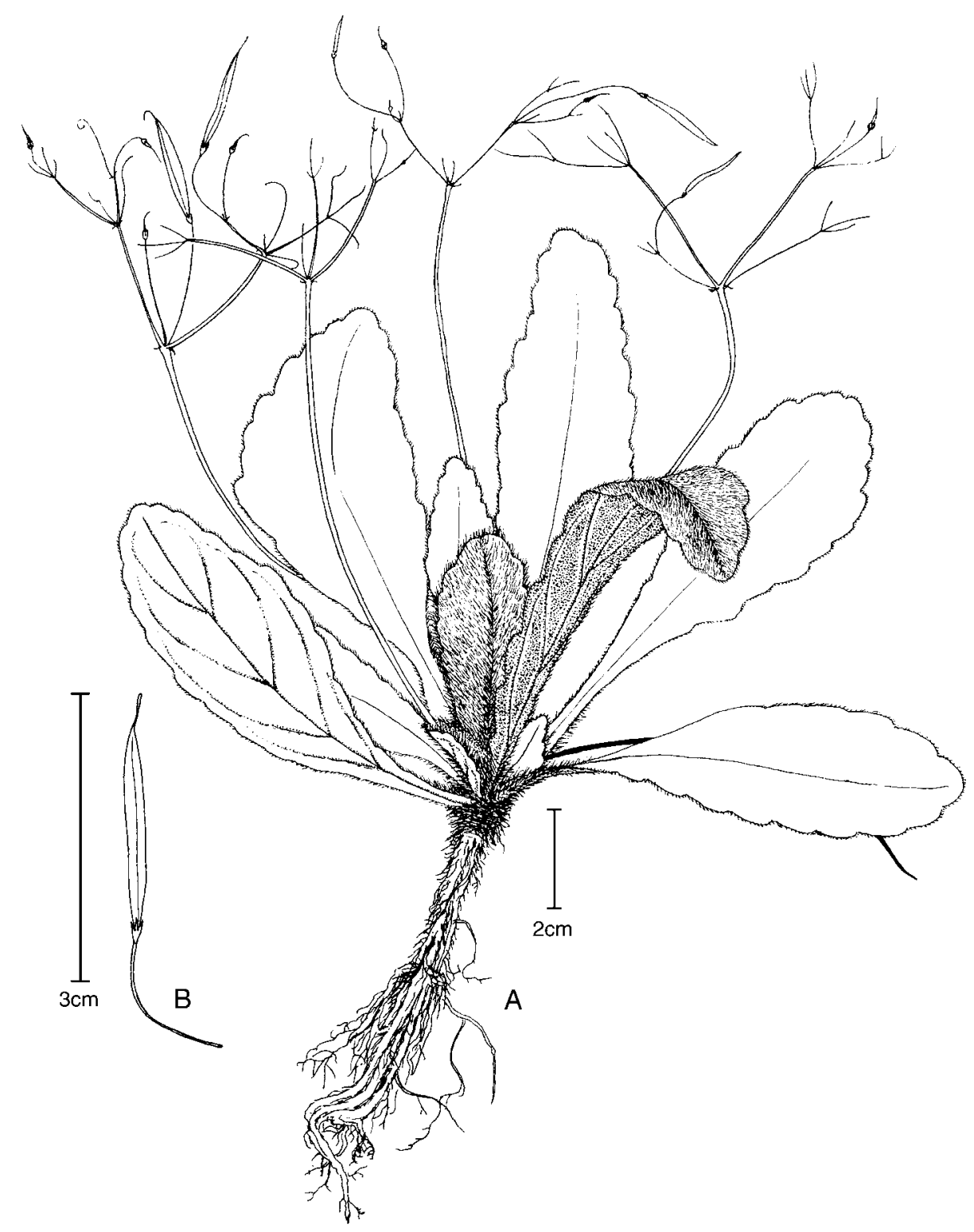

Fig. 25. Paraboea laxa Ridl. A, habit; B, fruit.

island to the south east, at Telok Sambar $\left[06^{\circ} 19^{\prime} \mathrm{N} 99^{\circ} 51^{\prime} \mathrm{E}\right], 10 \mathrm{~m}, 6$ xi 1971 (fr), S.C. Chin 1785 (K, L, SING); Tasek Dayang Bunting [06¹3'N 9949'E], 17 xi 1941 (fr), E.J.H. Corner s.n. (SING); Cult. in E C4063 (E, fl); Langkawi [06 $\left.20^{\prime} \mathrm{N} 99^{\circ} 48^{\prime} \mathrm{E}\right]$, iv 1892 (fl), C. Curtis 2571 (K); Kuah (Kedah) [06 $\left.19^{\prime} \mathrm{N} 99^{\circ} 51^{\prime} \mathrm{E}\right]$, ix 1900 (fl), M. Haniff \& C. Curtis s.n. (SING); Telok Apau [06 $\left.20^{\prime} \mathrm{N} 99^{\circ} 48^{\prime} \mathrm{E}\right], 17$ xi 1921 (fr), M. Haniff \& Nur 7083 (K, SING); Selat Panchor [06 25'N 9943'E], 21 xi 1934 (fr), M.R. Henderson SFN 21366 (K, SING); Batu Ayam, Selat 
Panchor, 21 xi 1934 (fr), M.R. Henderson SFN 29187 (K, SING); East End of Langkawi, facing P. Timun, face of Limestone cliff [06 $\left.18^{\prime} \mathrm{N} 99^{\circ} 52^{\prime} \mathrm{E}\right], 19$ viii 1972 (fr), B.C. Stone 11018 (E); Pulau Langkawi, forested limestone rocks near country club, 27 iv 1987 (fr), S. Stone \& A. Weber 87-0427 (WU).

Thailand. Kamphaeng Phet: [16³0’ N 99³5'E], 22 vi 1930 (fl, fr), Y. Kiah 24376 (BM, K, SING).

On the type material and the collections of this species from Langkawi the leaves have branched hairs and the leaf base is attenuate with no distinct petiole. The plant from Thailand, Kiah 24376 (K), is somewhat different to typical Paraboea laxa with its truncate to rounded leaf base, distinct petiole and an entire leaf margin, characters reminiscent of $P$. brunnescens. But the plant has branched hairs and a non-twisted capsule, linking it to Paraboea laxa rather than to P. brunnescens which has no branched hairs and a twisted capsule. Thus, Kiah 24376 may be an abnormal record of either Paraboea brunnescens or P. laxa, or it may be an undescribed species. Until more and better material is available we do not feel it is appropriate to create a new name for Kiah 24376. See also discussion under Paraboea vulpina.

44. Paraboea leopoldii K.M.Wong, J.T.Pereira, Sugau \& S.P.Lim, Sandakania 13: 28 (1999). - Type: Malaysia, Sabah, Semporna, Bodgaya island, sea fringe on north side, K. M. Wong, Postar Miun \& Ahmad Sappan WKM 2864 (holo SAN; iso E, K, $\mathrm{KEP})$.

Perennial herb, appearing rosulate by leaves crowded at apex of decumbent stem; stem woody, prostrate, c. $23 \mathrm{~cm}$ long, c. $4 \mathrm{~mm}$ in diameter. Leaves opposite, congested in a rosette, petiolate; petiole $3.5-4.5(-6) \mathrm{mm}$, with an arachnoid indumentum, later glabrescent; blades ovate, $5.9-6.8 \times 4.1-5.7 \mathrm{~cm}, 1.1-1.5$ times as long as wide, apex rounded, base cordate, margin entire, upper surface arachnoid, lower surface with a matted indumentum and an arachnoid covering; veins smooth above, raised beneath, lateral veins c.6-7 pairs, tertiary venation mostly invisible. Inflorescence axillary, cymose, much longer than the leaves, (16-)24-30 cm long, many-flowered, with arachnoid indumentum or glabrescent, except on the flower; peduncle 15-23 cm long, primary bracts elliptic, 6-9 mm long; pedicels 6-13 mm long. Calyx 2.8-3 $\times$ $0.7-0.8 \mathrm{~mm}, 5$-lobed to the base, lobes lanceolate, glabrous or with few sessile glands, especially inside. Corolla c. $8 \mathrm{~mm}$ long, 7-8 mm across; tube $4.2 \mathrm{~mm}$ long, limb slightly 2-lipped; upper lip 2-lobed, lobes rounded, c. $4.3 \times 5 \mathrm{~mm}$, lower lip slightly longer, 3-lobed, lobes rounded, c. $6.3 \times 5.3 \mathrm{~mm}$. Anthers \pm triangular, c. $2 \times 3.1 \mathrm{~mm}$, opening in the centre of the anther locules, coherent with each other, dorsifixed; filaments c. $4 \mathrm{~mm}$ long, inserted at base of the corolla tube, curved to make anther apex point towards gynoecium. Gynoecium c. $8 \mathrm{~mm}$ long; ovary $1.5 \mathrm{~mm}$ wide; style distinct, $0.8 \mathrm{~mm}$ wide; stigma slightly larger than style. Fruit a linear non-twisted capsule, 1-1.2 cm long, glabrous. Seeds not seen.

Distribution. Malaysia: Sabah. 
Habitat and ecology. On rocky headlands.

Proposed IUCN conservation assessment. Least Concern (LC). Although this species is known from very few collections the island where it was collected, Bodgaya, has long been protected.

Additional specimen examined. Malaysia. Sabah: Semporna District, Bod Gaya Island

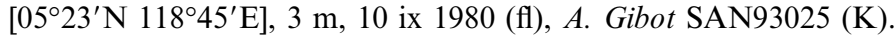

There are considerable problems in the delimitation of species in the group which comprises Paraboea leopoldii, P. minahassae, P. luzoniensis and P. schefferi. More collections are needed from Sulawesi, the Philippines and Borneo to clarify the issues but in this group Paraboea leopoldii is one of the more distinctive species with its strongly cordate leaf bases and no stalked glands on the inflorescence.

Two specimens from Sabah, Stone 6767 (KLU) and Meijer SAN23322 (SAN), may also belong to this species but better material is necessary to be sure of its identity. The leaves are more markedly separated by internodes and the blades less cordate than the Semporna material.

45. Paraboea leporina (H.J.Lam) B.L.Burtt, Notes Roy. Bot. Gard. Edinburgh 41: 431 (1984). - Boea leporina H.J.Lam, Blumea 5: 580, fig. 7 (1965). - Type: Central Celebes [Sulawesi], Enrokang, West of Kalosi, on limestone rocks, along road Kalosi-Makale, 800 m, xii 1937-xi 1939 (fl, fr), C. Monod de Froideville 401 (holo L).

Perennial caulescent herb or subshrub, monocarpic?; stem woody, c. $25 \mathrm{~cm}$ tall, 4 $10 \mathrm{~mm}$ in diameter, internodes 3-25 mm long. Leaves in whorls of 3, often congested, in one monocarpic plant internodes elongating to $1-2.5 \mathrm{~cm}$ long, sessile, obovate or narrowly so, $2.5-10 \times 0.8-2 \mathrm{~cm}, 2-5$ times as long as wide, obtuse at the apex, attenuate at the base, margin entire, dense white-arachnoid above, with a white or yellowish matted indumentum on the lower leaf surface; midrib smooth above, prominent beneath, lateral veins c. 6 pairs, obscure or prominent, tertiary venation obscure. Inflorescence paniculate, terminal, with a matted indumentum throughout except on the flower; flowering stem 6-12 cm long, the basalmost internode not especially elongated; floral leaves \pm intermediate to the vegetative leaves; 3 or 4 cymes from each node; cymes short, c.2-3 cm long, with a few to many flowers [Exception: G.K. Kjellberg 3939 has a cyme extending to c.20 cm long]; peduncle or pedicel bracts small, sepal-like, pedicel c.2-3 mm long. Calyx c. $2 \mathrm{~mm}$ long, with a whitish matted indumentum outside, glabrous inside, 5-lobed to the base, lobes c.1.3 mm long, narrow-ovate. Corolla glabrous, obscure purpureous; tube c. $2 \mathrm{~mm}$ long, limb 2-lipped; upper lip 2-lobed, lower lip 3-lobed, the lobes, excepting the middle lobe of the lower lip, of similar shape and size, rounded, c. $2 \times 2 \mathrm{~mm}$, middle lobe of the lower lip 2 times as long as the others. Stamens glabrous; filaments $2 \mathrm{~mm}$ long; staminodes 3; anthers transversely ellipsoid, 3-3.5 $\times 1.5 \mathrm{~mm}$, adnate to each other, opening in the centre of the anther locules, apex pointing towards the 
gynoecium. Gynoecium c. $6.5 \mathrm{~mm}$ long; ovary oblong, $2 \mathrm{~mm}$ long; style $4 \mathrm{~mm}$ long; stigma not especially enlarged. Fruit a spirally twisted capsule, c. $1.3-2.5 \mathrm{~cm}$ long, c. $1.3 \mathrm{~mm}$ across, glabrous. Seeds ellipsoid, c. $6 \times 2 \mathrm{~mm}$.

Distribution. Indonesia: Sulawesi.

Habitat and ecology. On limestone.

Proposed IUCN conservation assessment. Endangered (EN B1ab(ii,iii,v)). This species is only known from two localities. We are unclear how far apart the two localities are: if they are quite disconnected a status of Severely Fragmented may have been enough to push this into the higher category of CR. However, we are not sure if the extent of occurrence or area of occupancy is low enough to justify this. Further research is clearly necessary.

Additional specimen examined. Sulawesi. Rante Pal Bodenbeschaftenheit, Kalkfelsen, 12 xii 1929 (fl), G.K. Kjellberg 2919 (L, S).

The miniature appearance and its isolation in Sulawesi makes this species quite characteristic.

46. Paraboea leuserensis B.L.Burtt, Notes Roy. Bot. Gard. Edinburgh 41: 431 (1984). - Type: Indonesia, Atjeh [Aceh], Gunung Leuser Nature Reserve, Gunung Ketambe and vicinity, $8-15 \mathrm{~km}$ SW from the mouth of Lau Ketambe, c. $40 \mathrm{~km} \mathrm{NW}$ of Kutatjane, $800 \mathrm{~m}$, on shaded limestone rock in montane rain forest, 16 vii 1969, W.J.J.O. de Wilde \& B.E.E. de Wilde-Duyfjes 13639 (holo L). Fig. 26.

Perennial rosulate herb, sometimes with a rhizome up to $10 \mathrm{~cm}$ long. Leaves oppositely congested in a rosette, petiolate; petiole c.4-11 cm long, with a brown matted indumentum; blades \pm elliptic, in rare cases appearing slightly ovate or obovate, $10-28 \times 5-9 \mathrm{~cm}, 1.5-4$ times as long as wide, apex acute or obtuse, base cuneate to truncate, margin entire or indistinctly crenulate or serrulate, upper surface arachnoid when young and glabrescent when mature, lower surface with a matted indumentum; veins smooth above, raised beneath, lateral veins c.8-12 pairs, tertiary venation invisible. Inflorescence axillary, cymose, shorter than or equal to the leaves, c.15-30 cm long, few- to many-flowered, with a brown matted indumentum throughout except on the flower; peduncle 14-24 cm long, primary bracts narrowly ovate, $5-15 \mathrm{~mm}$ long; pedicels longer or similar in length to the primary branches of the cyme, 5-35 mm long. Calyx 3-6 mm long, 5-lobed to the base, lobes lanceolate, with a brown matted indumentum on both sides. Corolla c. $15 \mathrm{~mm}$ across, $10 \mathrm{~mm}$ long; tube c. $2 \mathrm{~mm}$ long, limb slightly 2-lipped; upper lip c. $6 \times 6.5 \mathrm{~mm}, 2$-lobed, lobes \pm rounded, lower lip slightly longer, c. $10 \times 8 \mathrm{~mm}$, 3-lobed, lobes \pm rounded. Anthers transversely ellipsoid, c. $1.2 \times 2.5 \mathrm{~mm}$, opening in the centre of the anther locules, coherent with each other; filaments c. $2 \mathrm{~mm}$ long, inserted at the base of the corolla, curved and making anthers point to gynoecium; 


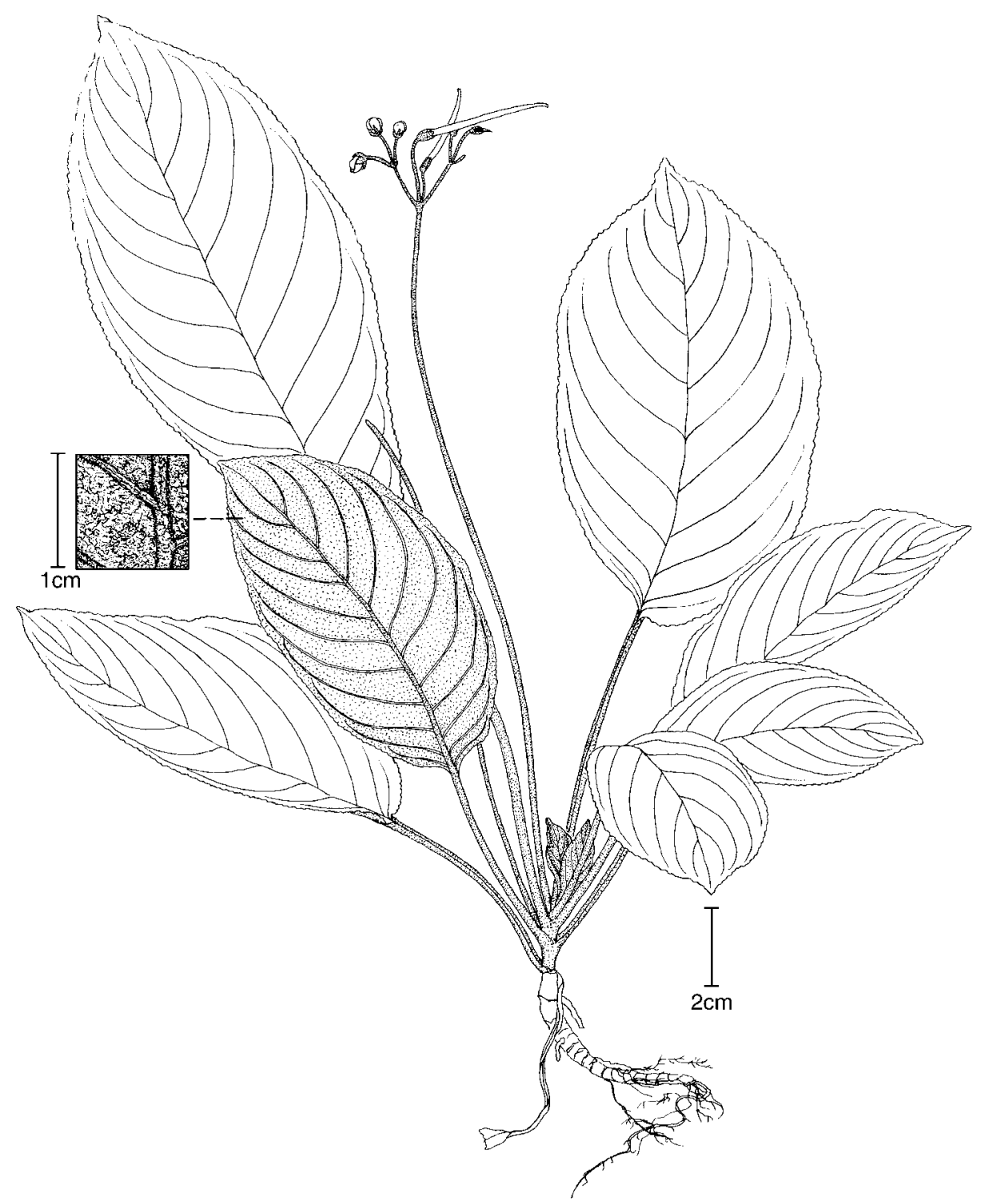

FIg. 26. Paraboea leuserensis B.L.Burtt.

staminodes $0.5 \times 0.1 \mathrm{~mm}$. Gynoecium narrowly ovoid, c. $6 \mathrm{~mm}$ long; style indistinct; stigma not much larger than style. Fruit a linear non-twisted capsule, 2-3 cm long, glabrous, dehiscing along the upper suture. Seeds brown, ellipsoid, c. $0.4 \times$ $0.1 \mathrm{~mm}$.

Distribution. Indonesia: Sumatra (Aceh Province). 
Habitat and ecology. Reported from limestone.

Proposed IUCN conservation assessment. Least Concern (LC). Although this species is known from relatively few collections these are mostly from Gunung Leuser Nature Reserve, a protected area, and there are no major threats.

Additional specimens examined. Indonesia. Sumatra: Aceh: Gunung Leuser Nature Reserve, Ketambe, valley of Lau Alas, near tributary of Lau, 200-400 m, 29 v 1972 (fr), W.J.J.O. de Wilde \& B.E.E. de Wilde-Duyfjes 12469 (K, L, US); Gunung Leuser Nature Reserve, c.7 km SW from the mouth of Lau Ketambe, Climbing Gunung Mamas $\left[03^{\circ} 00^{\prime} \mathrm{N} 97^{\circ} 50^{\prime} \mathrm{E}\right]$, 1200-1400 m, 6 v 1975 (fl), W.J.J.O. de Wilde \& B.E.E. de Wilde-Duyfjes 16619 (K, L, US); Gunung Leuser Nature Reserve, c.6 km SW from the mouth of Lau Ketambe, 12-1500 m, 23 iii 1975 (fr, fl), W.J.J.O. de Wilde \& B.E.E. de Wilde-Duyfjes 15747 (K, KEP, L, MO, US); Gunung Leuser Nature Reserve, Alas River valley near mouth of Renun, 50-125 m, 21 vii 1979 (fl), W.J.J.O. de Wilde \& B.E.E. de Wilde-Duyfjes 18968 (L); Gunung Leuser Nature Reserve, Camp 1 Climbing Gunung Mamas c.5 km SW from the mouth of Lau Ketambe, 1000 m, 5 v 1975 (fl), W.J.J.O. de Wilde \& B.E.E. de Wilde-Duyfjes 16590 (K, L).

Odd collection: Indonesia. Sumatra: Aceh: Archipel. Ind. Gajolanden. From Kongke to Goempang $\left[03^{\circ} 00^{\prime} \mathrm{N} 97^{\circ} 50^{\prime} \mathrm{E}\right], 1000 \mathrm{~m}, 5$ iii 1937 (fl, fr), C.G.G.J. van Steenis 9503 (K, L).

The species is similar to Paraboea capitata (var. oblongifolia) but its long pedicels, resulting in a lax appearance to the (non-capitate) inflorescence, means that it is easily distinguished from this species.

47. Paraboea luzoniensis Merr., Philipp. J. Sci. 1: Suppl. 225 (1906); Burtt, Notes Roy. Bot. Gard. Edinburgh 41: 432 (1984). - Type: Luzon, Cavite Province, Maragongdong, 100-400 m, vii 1905 (fl, fr), Merrill 4178 (lecto L, designated by Burtt (1984: 432); iso E, K, NY, P). Fig. 27.

Paraboea ridleyi Elmer, Leafl. Philipp. Bot. 3: 949 (1910); Burtt, Notes Roy. Bot. Gard. Edinburgh 41: 435 (1984). - Type: Philippines, Mindanao, district of Davao, Mt. Apo, Elmer 11145 (lecto E, designated by Burtt (1984: 435); iso BM, K, L, NY, W).

Perennial rosulate herb, sometimes seen with a subterraneous stem (or rhizome) up to $10 \mathrm{~cm}$ long. Leaves congested in a rosette or opposite on an extending stem or rhizome, petiolate; petiole $2-10 \mathrm{~cm}$ long, slightly enlarged at the base and joining across the node, with a brownish matted indumentum; blades \pm ovate, $4-10 \times 2.5-$ $6 \mathrm{~cm}, \mathrm{c} .1-1.5$ times as long as wide, apex obtuse to rounded, base truncate, subcordate or cordate, margin entire, upper surface arachnoid when young and later glabrescent, lower surface with a generally brownish (or in rare cases whitish) matted indumentum; veins smooth above, raised beneath, lateral veins c. 8 pairs, tertiary venation inconspicuous. Inflorescence an axillary cyme, 14-20 cm long, with several to many flowers, possessing some matted indumentum and with minute stalked glands throughout except on the flower; peduncles 5-14 cm long; with two primary bracts, narrowly ovate, $3 \mathrm{~mm}$ long, minutely pubescent on the upper 


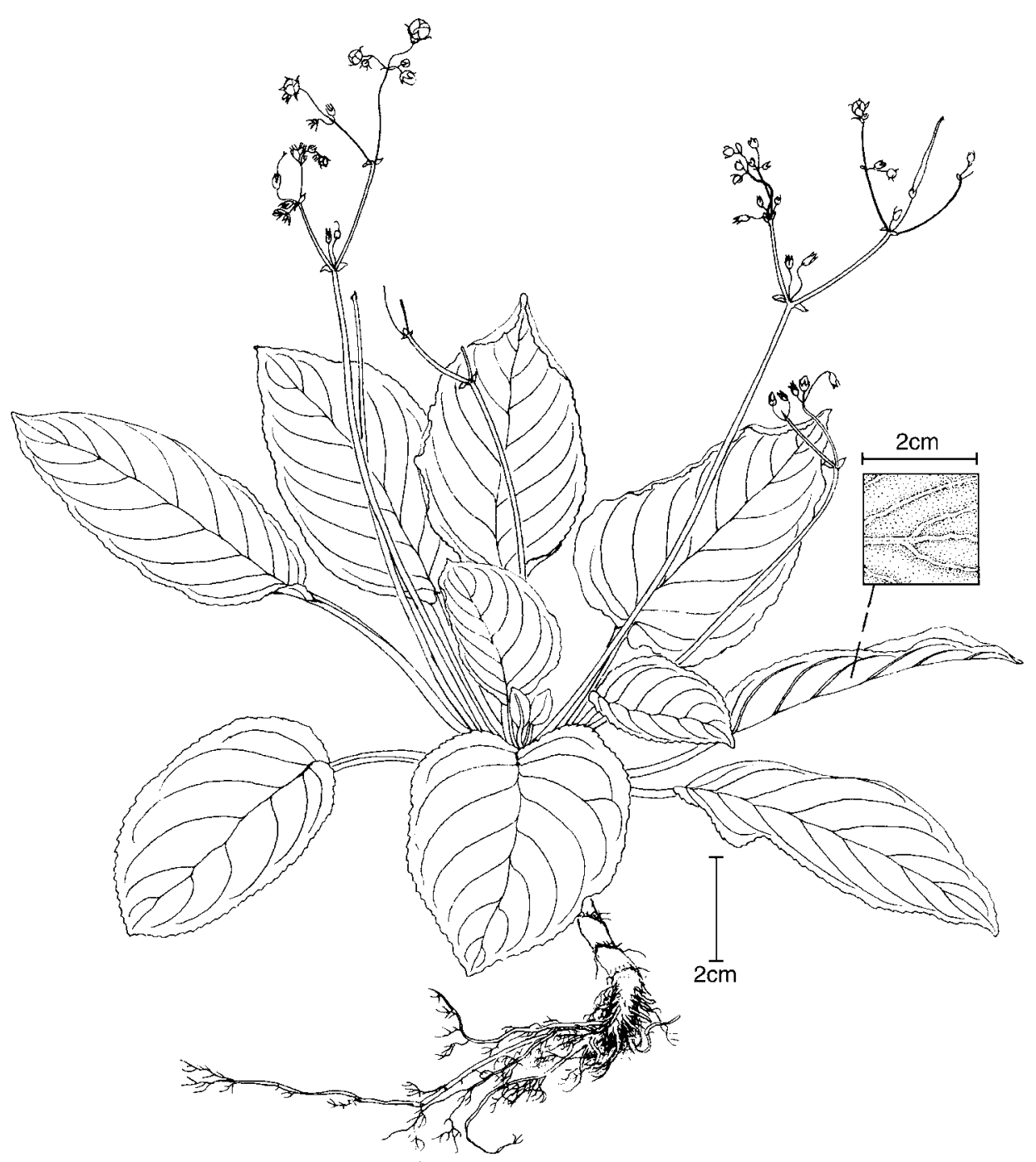

FIg. 27. Paraboea luzoniensis Merr.

surface; pedicels c.10-15 mm long, glabrescent, or rarely with a minute glandular pubescence, with sepal-like bracts. Calyx lobes narrowly ovate, $3 \times 0.8 \mathrm{~mm}$, glabrous outside, with a very minute pubescence (or sessile glands) inside. Corolla violet or violet-blue, $8 \mathrm{~mm}$ long, $12 \mathrm{~mm}$ across, \pm minutely pubescent outside, glabrous inside; tube c. $4 \mathrm{~mm}$ long, limb distinctly 2-lipped; upper lip 2-lobed, rounded, c. $4 \times$ $3.5 \mathrm{~mm}$, lower lip 3-lobed, rounded, c. $4.5 \times 5.5 \mathrm{~mm}$. Anthers \pm triangular, c. $2.2 \times$ $3 \mathrm{~mm}$, opening in the centre of the anther locules, coherent with each other, dorsifixed; filaments c. $3.5 \mathrm{~mm}$ long, inserted $2 \mathrm{~mm}$ from the corolla base, curved to make anther apex point towards gynoecium. Gynoecium $7 \mathrm{~mm}$ long; ovary $1 \mathrm{~mm}$ 
wide; style distinct, $0.3 \mathrm{~mm}$ wide; stigma slightly larger than style. Fruit a linear nontwisted capsule, 1.5-4 cm long, glabrous. Seeds ovoid, $0.4 \times 0.2 \mathrm{~mm}$.

Distribution. Philippines.

Habitat and ecology. On limestone.

Proposed IUCN conservation assessment. Least Concern (LC). This species has been collected at several sites over a wide area and there are no major threats.

Additional specimens examined. Philippines. Mindanao: Bukidnon: $\left[08^{\circ} 05^{\prime} \mathrm{N} 125^{\circ} 03^{\prime} \mathrm{E}\right]$, viii 1912 (fl), E. Fenix 15780 (BM); Bukidnon subprovince, Vicinity of Tangkulan, [08 $20^{\prime} \mathrm{N}$ 12450'E], vii 1916 (fl), E. Fenix 2107 (P), vii 1916 (fl, fr), E. Fenix 24945 (K, NY, US). Zamboanga: [06 $55^{\prime} \mathrm{N} 122^{\circ} 05^{\prime} \mathrm{E}$ ], xi-xii 1911 (fr), E.D. Merrill 8150 (K, US); Santa Maria, ix-x 1912 (fr), J. Reillo BS16451 (BM, K, US), ix-x 1912, J. Reillo BS16513 (BM, L). Panay:

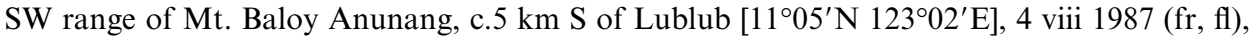
G.S. Vavadavajan et al. 1520 (K); Igbaras, Ilo-ilo [10 $40^{\prime} \mathrm{N} 122^{\circ} 40^{\prime} \mathrm{E}$ ], iii 1886 (fr), S. Vidal y

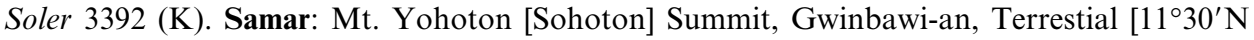
1245'ㄹ, 600 m, iv 1970 (fl), Gutierrez et al. 1081 (L). Sulu Archipelago: Kabungan, Jolo

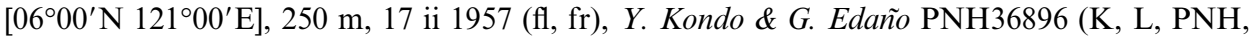
US). Tawi-Tawi: Tawi-Tawi island, Silisad, Bongao Peak [05 $\left.01^{\prime} \mathrm{N} 119^{\circ} 45^{\prime} \mathrm{E}\right], 227 \mathrm{~m}, 23 \mathrm{v}$ 1992 (fl), F.J.M. Gaerlan \& E.C. Sagcal PPI10037 (E).

There are no outstanding differences between the types of the two names being merged (Paraboea luzoniensis and $P$. ridleyi) except that in the type of $P$. luzoniensis the leaf texture seems thinner and the inflorescence looks shorter. These differences do not warrant specific delimitation. Several other collections included in this name expand the distribution area of this species into both the Philippines and Borneo. Even so, the species has relatively consistent morphology in the habit, the leaf morphology and the inflorescence. This species is close to Paraboea schefferi, $P$. minahassae and $P$. leopoldii (see discussions under those species).

48. Paraboea madaiensis Z.R.Xu \& B.L.Burtt, Edinburgh J. Bot. 48 : 4 (1991). - Type: Borneo, Sabah, Lahad Datu District, around Madai cave $\left[05^{\circ} 15^{\prime} \mathrm{N}\right.$ 118 $18^{\prime} \mathrm{E}$ ], 90-150 m, 15 ix 1976 (fl), Tamura \& Hotta 722 (holo E; iso KYO). Fig. 28.

Perennial caulescent subshrub, 40-80 cm tall; stem woody, nearly $1 \mathrm{~cm}$ in diameter, internodes c. $0.5 \mathrm{~cm}$ long, tawny lanate when young (1-2 years old), glabrescent when older (3 years or more). Leaves in whorls of 3, distinctly petiolate; petiole c.1-2 cm long, terete, with similar indumentum to the stem; blades ovate, c. $3-4 \times 1.5-2 \mathrm{~cm}$, c. 2 times as long as wide, apex acute, base truncate, margin entire, upper surface with a dense pubescence under a layer of white arachnoid indumentum, lower surface with a white matted indumentum; veins obscure above and beneath, lateral veins c. 6 pairs, tertiary venation obscure. Inflorescence terminal, paniculate, c.15 cm long, rather narrow, c. $3 \mathrm{~cm}$ wide, with a matted indumentum throughout except on the flower; the basalmost internode of the flowering stem c.3-5 cm long, floral leaves 

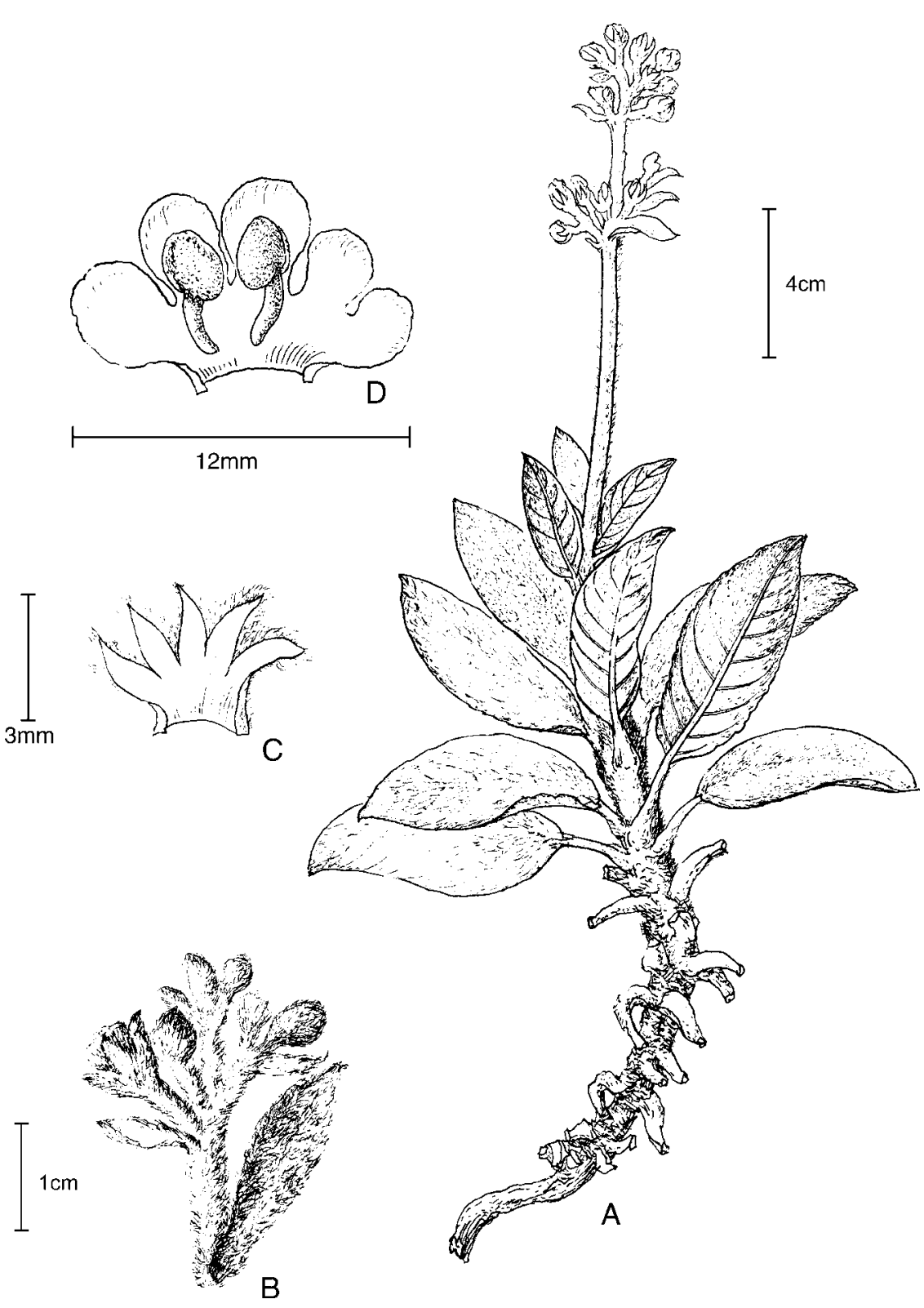

FIg. 28. Paraboea madaiensis Z.R.Xu \& B.L.Burtt. A, habit; B, inflorescence; C, calyx opened out; D, corolla opened out.

intermediate to the cauline ones, normally without petiole, 2 or 3 cymes at each node; cymes short, with or without a short peduncle, peduncle bracts and pedicel bracts similar to calyx lobes; pedicels $5-10 \mathrm{~mm}$ long. Flowers glabrous except on the 
calyx, sometimes the lanate hairs extending to the corolla outside. Calyx c. $3 \mathrm{~mm}$ long, 5-lobed to the base, lobes narrow-ovate, lanate outside. Corolla pale violet, c. $8 \mathrm{~mm}$ long, $9 \mathrm{~mm}$ across; tube $2.5 \mathrm{~mm}$ long, limb 2-lipped; upper lip 2-lobed, lobes wide-ovate, $3 \times 3.5 \mathrm{~mm}$, lower lip c. $5 \mathrm{~mm}$ long, 3-lobed, middle lobe slightly smaller than the two lateral lobes, obovate, $3 \times 3.5 \mathrm{~mm}$, two lateral lobes equal, ovate, $4 \times$ $5 \mathrm{~mm}$. Anthers yellow, transversely ellipsoid, c. $2 \times 3.5 \mathrm{~mm}$, coherent at the apex and the base, opening in the centre of the anther locules, apex turned towards the gynoecium, dorsifixed; filaments c. $2.5 \mathrm{~mm}$ long, $0.7 \mathrm{~mm}$ wide; ovary ovoid, $1.5 \times$ $1 \mathrm{~mm}$; style c. $3 \mathrm{~mm}$ long; stigma capitate, not larger than style. Fruit a spirally twisted capsule, linear, c. $1.3 \mathrm{~cm}$ long, $1.2 \mathrm{~mm}$ in diameter, glabrous. Seeds compressed, ellipsoid, $0.5 \times 0.15 \mathrm{~mm}$.

Distribution. Malaysia: Sabah.

Habitat and ecology. On limestone.

Proposed IUCN conservation assessment. Least Concern (LC). The conservation assessment given reflects the fact that although this species is known from few collections they are all from a limestone area that is in the Madai Baturong Forest Reserve and there are no major threats.

Additional specimens examined. Malaysia. Sabah: Lahad Datu District, Madai Forest

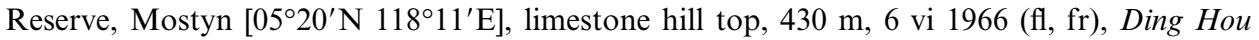
166 (A, K, L); Madai, Lahad Datu, Madai limestone hill, E coast Darrel Bay, 305 m, 16 vi 1963 (lv), W. Meijer SAN37962 (K); Batu Tengar Cave, Segarong P.F.R., 200 m, R. Kiew RK 4318 (KEP, SAN).

This species is close to Paraboea candidissima as well as to P. sabahensis but the leaves are much smaller than in $P$. candidissima and the truncate leaf base and distinct petiole distinguish it from $P$. sabahensis. Kiew (1998) noted that this species is used medicinally by local people.

49. Paraboea mahaxayana Z.R.Xu \& B.L.Burtt, Edinburgh J. Bot. 48 : 5 (1991). - Type: Laos, Prov. de Cammoun [Khammouane], village de Mahaxay [17 $25^{\prime} \mathrm{N}$ $105^{\circ} 12^{\prime} \mathrm{E}$ ], $150 \mathrm{~m}$, fissures d'un gros rocher calcaire dans un forêt de haute futaie très humide, 22 i 1931 (fr), Pételot s.n. (holo P; iso E). Fig. 29.

Perennial rosulate herb. Leaves congested in a rosette, shortly petiolate; petiole up to $1.5 \mathrm{~cm}$ long, with the same indumentum as that on the underside of the blades; blades coriaceous, obovate, $6-10 \times 2.5-5 \mathrm{~cm}, 1.5-2.5$ times as long as wide, apex rounded, base attenuate to rounded, margin crenulate to crenate, upper surface arachnoid when young, glabrescent when older, lower surface with a brownish yellow matted indumentum; veins smooth above, prominent beneath, lateral veins c.10 pairs, tertiary venation conspicuous and reticulate. Inflorescences axillary, cymose, with a very slender peduncle, several (c.2-4) clustered on an indistinct (extremely short) stalk from an axil, normally longer than the leaves, when in fruit 


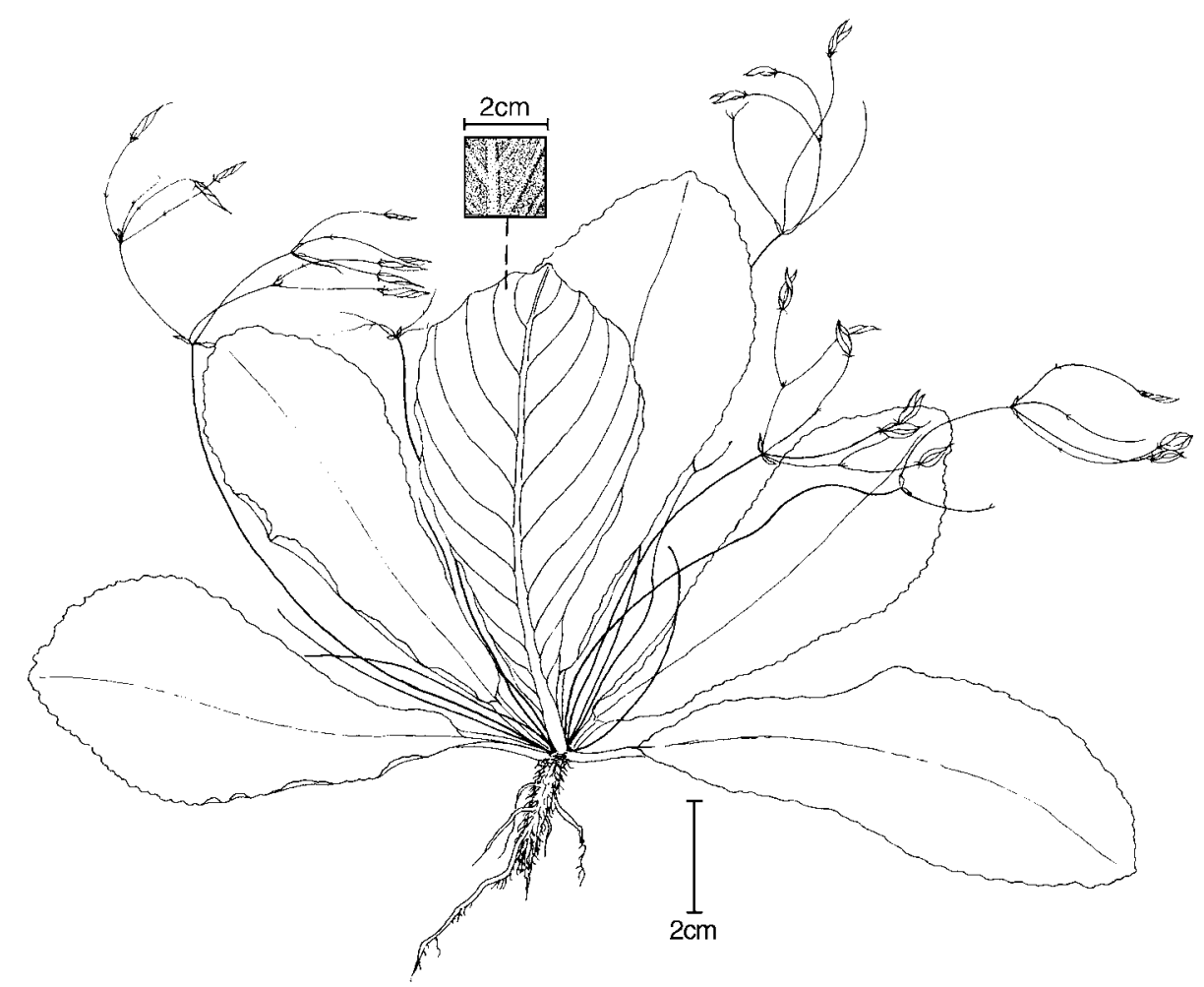

FIg. 29. Paraboea mahaxayana Z.R.Xu \& B.L.Burtt.

up to $15 \mathrm{~cm}$ long, very lax, several-flowered, with the same indumentum as that on the lower leaf surface; peduncle up to $10 \mathrm{~cm}$ long, c. $0.3 \mathrm{~mm}$ in diameter, peduncle bracts narrowly ovate, $3 \times 0.5 \mathrm{~mm}$; pedicels long and slender, up to $40 \mathrm{~mm}$ long. Calyx persistent, 5-lobed to the base; lobes narrowly ovate or triangular, c. $2 \mathrm{~mm}$ long, $0.5 \mathrm{~mm}$ wide. Corolla not seen. Fruits short, $0.5-0.8 \mathrm{~cm}$ long, $1-1.5 \mathrm{~mm}$ wide, glabrous, twisted; style persistent on the capsule with a minute pubescence. Seeds ovoid, $0.4 \times 0.15 \mathrm{~mm}$.

Distribution. Laos. Known only from the type.

Habitat and ecology. On limestone.

Proposed IUCN conservation assessment. Critically Endangered (CR B1ab(ii,iii,v)) see conservation assessment section in introduction.

The species is remarkable in that each fertile axil develops 2-4 cymes from an extremely short stalk and the cyme has an extremely slender peduncle with very few flowers. In addition it has a distinctive very short capsule. In its rosulate habit and 
the \pm obovate leaves this species is similar to Paraboea neurophylla, P. crassifolia and $P$. dictyoneura. In Paraboea neurophylla two cymes sometimes develop in a single axil.

50. Paraboea martinii (H.Lév.) B.L.Burtt, Notes Roy. Bot. Gard. Edinburgh 38: 470 (1980); Burtt, Notes Roy. Bot. Gard. Edinburgh 41: 432 (1984). - Boea martinii H.Lév., Fl. Kouy-Tchéou, 180 in clavi, 181 (1914). - Type: China, Kweichow [Guizhou Province], environs de Gan-pin [near Pinba], [c.26²6' N 106 $16^{\prime} \mathrm{E}$ ], 13 vi 1898 (fl), Martin in herb. Bodinier 2378 (holo E; iso P). Fig. 30.

Paraboea barbartipes K.Y.Pan, Acta Phytotax. Sin. 26: 441 (1988); K.Y.Pan in Wang et al., Fl. Reipubl. Popularis Sin. 69: 468 (1990). - Type: China, Guangxi, Napo, on limestone, D. Fang et al. 22417 (holo PE).

Paraboea clavisepala D.Fang \& D.H.Qin, Acta Phytotax. Sin. 33: 602 (1995). - Type: China, Guangxi, Napo, on limestone, D. Fang et al. 79619 (holo GXMI).

Perennial rosulate herb, with a short stem c.10 cm long, 5-8 $\mathrm{mm}$ in diameter. Leaves opposite, petiolate; petiole c.3-10 cm long; blades elliptic, 8-14 $\times 3-5 \mathrm{~cm}$, 2.5-4 times as long as wide, apex acute, base cuneate, margin entire or slightly crenulate, upper surface with some arachnoid indumentum or glabrescent, lower surface with a pale brown matted indumentum; veins obscure above, prominent beneath, lateral veins c. 11 pairs, tertiary venation reticulate. Inflorescence a terminal panicle, with a matted indumentum on the flowering stem and the floral leaves but less pubescence on the peduncles and the pedicels; flowering stem c. $30 \mathrm{~cm}$ long, elongating to c.15-20 cm long between the axil of the uppermost normal vegetative leaves and the lowest axil bearing a cyme, with 1-2 pairs of much reduced floral leaves in-between, c. $3 \times 1.2 \mathrm{~cm} ; 2$ cymes at each node, the lowest axillary cymes 10-15 cm long, many-flowered; peduncle 5-7 cm long, peduncle bracts narrowovate, $<1 \mathrm{~cm}$ long; pedicel c.7 mm long, with bracts sepal-like. Flowers large, glabrous or in rare cases with some pubescence on the calyx and the corolla outside. Calyx 2-3 mm long, 5-lobed to the base, lobes narrow-oblong or ovate, c. $2.8 \times 0.8 \mathrm{~mm}$. Corolla blue, c. $1.5 \mathrm{~cm}$ long, $1.2 \mathrm{~cm}$ across when fully open, tube c. $7 \mathrm{~mm}$ long, slightly swelling in the middle, limb with 2 lips; upper lip with 2 lobes, semi-circular, c. $3 \times 4 \mathrm{~mm}$, lower lip c. $8 \mathrm{~mm}$ long, with 3 lobes, middle lobe semicircular, c. $4.5 \times 5 \mathrm{~mm}$, two lateral lobes wide-ovate, c. $2.5 \times 4 \mathrm{~mm}$. Stamens 2 , anthers transversely ellipsoid, c. $1.5 \times 4 \mathrm{~mm}$, with apex pointing towards the gynoecium, coherent with each other at the apex, apertured at the upward end, dorsifixed; filaments c. $10 \mathrm{~mm}$ long, curved into a knee in the middle with a beard of branched multicellular hairs. Gynoecium c. $9 \mathrm{~mm}$ long, $1 \mathrm{~mm}$ at the widest, stigma capitate. Fruit a spirally twisted capsule, c. $3.5 \mathrm{~cm}$ long, $1.2 \mathrm{~mm}$ wide, glabrous. Seeds ellipsoid, $0.7 \times 0.2 \mathrm{~mm}$.

Distribution. China: Guangxi, Guizhou and Yunnan.

Habitat and ecology. On limestone. 


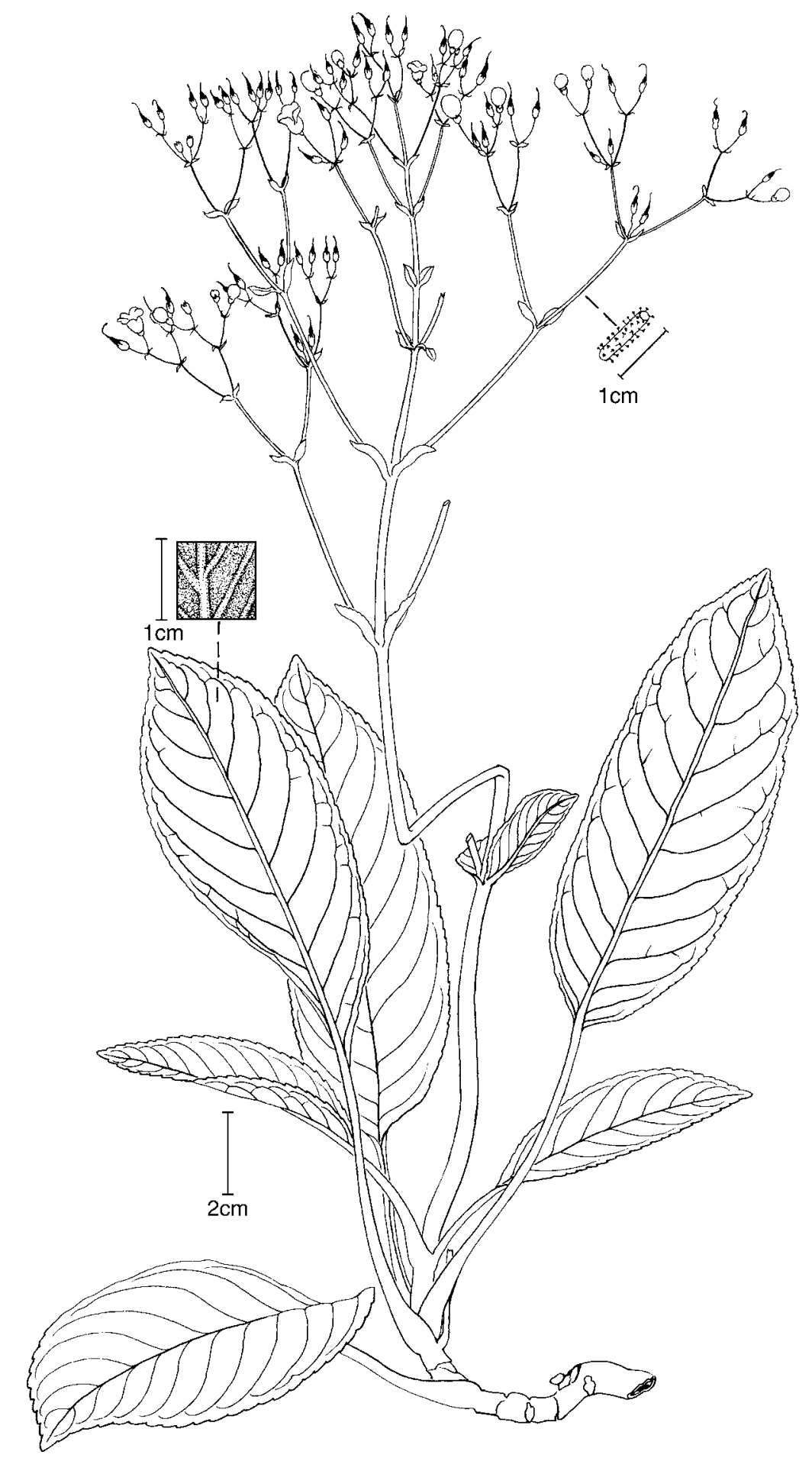

Fig. 30. Paraboea martinii (H.Lév.) B.L.Burtt. 
Proposed IUCN conservation assessment. Least Concern (LC). Although the species is only known from few collections these are distributed over a very wide area and it is likely that it will be found in many more limestone ranges with further exploration, and there are no major threats.

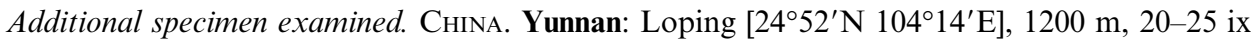
1985 (fr), Z.R. Xu LM4994 (E, SYS).

When Pan (1988) published her species Paraboea barbartipes she stated that it was unique in the genus in the possession of a beard of hairs on the filaments. However, all the specimens of Paraboea martinii, P. glutinosa and $P$. thorelii examined in our study possess this character. Paraboea barbartipes has been reduced to a synonym of P. martinii (H.Lév.) B.L.Burtt (1984).

The French missionaries' spellings for some Chinese places like Gan-chouentchiou, Gan-chouen-fou and Gan-pin (in Guizhou Province) seem to have derived from the local dialect pronunciation. From the first author's experience in minority areas of Guizhou the locals pronounce the Mandarin An (meaning 'peace' or 'safe') as Ngan, similar to a linguistic element in the Vietnamese language. French has no $\mathrm{Ng}$ at the beginning of a word and they appeared to have spelled Ngan as Gan. Tchiou is no doubt zhou in the Chinese Pinyin system (Zhou is a district or a county), fou is $f u$ (a city or a prefecture then). Thus, Ganchouen-fou [= An1Shun4Fu3] should be today's Anshun City (c. $26^{\circ} 15^{\prime} \mathrm{N}$ $\left.106^{\circ} 56^{\prime} \mathrm{E}\right)$, Gan-chouen-tchiou [= An1Quan2Zhou1, a safe county] should be today's Changshun County $\left(\mathrm{c} .26^{\circ} 02^{\prime} \mathrm{N} 106^{\circ} 29^{\prime} \mathrm{E}\right)$, and Gan-pin [= An1Pin2, a safe place] should be today's Pingba town (c.26 $26^{\prime} \mathrm{N} 106^{\circ} 16^{\prime} \mathrm{E}$ ). These interpretations are supported by studying the map made by Léveillé in his Fl. Kouy-Tchéou (Flora of Guizhou).

In the protologue for Paraboea clavisepala a wonderful line drawing (p. 603) of this newly published taxon points directly to the earlier published Paraboea barbartipes. The type of Paraboea clavisepala is a paratype of P. barbartipes collected from exactly the same locality by the same collector (D. Fang et al.). Obviously the collector sent some of the collections to PE and IBSC, which were identified as Paraboea barbartipes K.Y.Pan (sp. nov. in 1988) and later re-annotated as P. martinii (H.Lév.) B.L.Burtt by K.Y. Pan. D. Fang et al. selected a paratype collection of Paraboea barbartipes for their new taxon P. clavisepala D.Fang \& D.H.Qin.

50a. Paraboea aff. martinii, sp. nov.?

China. Yunnan: Maguan Co., Gulinqing, on limestone rock, [22 $\left.58^{\prime} \mathrm{N} 104^{\circ} 28^{\prime} \mathrm{E}\right], 1500-1700 \mathrm{~m}$, 1-20 iv 1986 (fr), Z.R. Xu GL86-7477 (E, SYS).

Vietnam. Lao Cai: massif vers $1600 \mathrm{~m}$, env. de Chapa $\left[22^{\circ} 21^{\prime} \mathrm{N} 103^{\circ} 50^{\prime} \mathrm{E}\right]$, viii 1930 , A. Pételot s.n. (P). Khanh Hoa: Hon Heo, Nha Trang [12 $\left.24^{\prime} \mathrm{N} 109^{\circ} 16^{\prime} \mathrm{E}\right], 28$ ix 1922 (fr), E. Poilane $4751(\mathrm{P}) ; 14 \mathrm{~km}$ Nha Trang, $300 \mathrm{~m}, 2 \mathrm{~km}$ de la mer (Ninh Thuan, Binh Thuan, Binh Tuy), 22 ix 1922 (fr), E. Poilane 4676 (P). 
$X u$ GL86-7477 may be an undescribed species related to Paraboea martinii. It differs from Paraboea martinii in the leaf blades being wide-ovate to circular, c. 7.5-26 $\times(3-) 7-14.5 \mathrm{~cm}, 1-2.5$ times as long as wide, obtuse or rounded at the apex and truncate to shallowly cordate at the base. Although there is no flowering material it can be seen from its dried infructescence that it has a terminal panicle, a flowering stem c. $35 \mathrm{~cm}$ long and fruits of a spirally twisted capsule, c. $1.5 \mathrm{~cm}$ long. The Vietnamese material is similar but quite far removed from the specimen from China. A new name or new names will be established for the above group of collections when sufficient material is available.

51. Paraboea mataensis Z.R.Xu \& B.L.Burtt, Edinburgh J. Bot. 48 : 5 (1991). - Type: Sulawesi, N shore of Lake Mata on East of Nuha (c. $\left.2^{\circ} 27^{\prime} \mathrm{S} 121^{\circ} 22^{\prime} \mathrm{E}\right)$, in patches of coastal forest up to $20 \mathrm{~m}$ tall along the lake, bedrock conglomerate cemented together by sandstone, covered by a thin layer of humus, rather common solitary herb on steep slope, 400 m, 16 vi 1979 (fl, fr), M.M.J. van Balgooy et al. 5822 (holo L).

Large perennial herb, caulescent, erect, monocarpic, up to $1 \mathrm{~m}$ tall (including the inflorescence); stem terete, up to $1.2 \mathrm{~cm}$ in diameter; internodes quite short, normally $<1 \mathrm{~cm}$ long, up to $2 \mathrm{~cm}$ long (excluding those on the flowering stem), with a thick layer of lanate indumentum. Leaves in whorls of 4, indistinctly petiolate, the leaf bases longattenuate to the base of the petioles and more or less joining each other across the node, more or less obovate to narrow-oblong, 5-18 $\times 1-3.5 \mathrm{~cm}, 5-10$ times as long as wide, apex short-acute, base long-attenuate, margin entire, with a dense pubescence covered by an arachnoid indumentum on the upper surface, with a thick layer of brownish lanate hairs on the undersurface; veins smooth above, raised beneath, lateral veins c.10 12 pairs, tertiary venation invisible. Inflorescence terminal, paniculate, c. $40-50 \mathrm{~cm}$ long, whitish or brownish lanate except on the flower and the upper half of the pedicel; flowering stem quadrangular or multi-ridged, internodes up to $10 \mathrm{~cm}$ long, floral leaves intermediate to the cauline ones and reducing in size upward, 4 cymes from each node; cymes up to $20 \mathrm{~cm}$ long, much branched, with numerous flowers, peduncle up to $14 \mathrm{~cm}$ long with obovate-oblong bracts $8 \times 1.5 \mathrm{~mm}$; pedicels $<5 \mathrm{~mm}$ long, the upper half not sublanate but more or less pubescent (or rather, minutely capitate-glandular). Calyx 5-lobed to the base, lobes ovate, c. $2 \times 0.6 \mathrm{~mm}$, more or less minutely pubescent on both sides. Corolla c. $8 \times 12 \mathrm{~mm}$ when open; tube c. $2 \mathrm{~mm}$ long, limb ciliate, conspicuously 2-lipped; upper lip c. $6 \times 8 \mathrm{~mm}$, with a sinus c. $3 \mathrm{~mm}$ deep, lower lip c. $8 \times 10 \mathrm{~mm}$, obovate, 3-lobed, middle lobe surpassing the side ones by c. $3 \mathrm{~mm}$, more or less obovate, c. $5 \times 3.5 \mathrm{~mm}$. Stamens 2 ; anthers transversely ellipsoid, c. $2 \times 4 \mathrm{~mm}$, open in the centre of the anther locules, coherent with each other at the apex and the base, apex turned towards the gynoecium, dorsifixed; filaments inserted at the base of the corolla, c. $4 \mathrm{~mm}$ long, $1.2 \mathrm{~mm}$ wide, flat, verrucose and crenate on the edge; staminodes 2, 0.5-2 mm long. Ovary c. $2 \times 0.8 \mathrm{~mm}$; style distinct from the ovary, c. $6.5 \times 0.3 \mathrm{~mm}$; stigma capitate, slightly larger than style. Fruit linear, 1-2.5 cm long, $12 \mathrm{~mm}$ in diameter, glabrous, spirally twisted. Seeds ovoid (brown), $0.6 \times 0.2 \mathrm{~mm}$, with two dark brown tips. 
Distribution. Indonesia: Sulawesi.

Habitat and ecology. On soils over conglomerate rock.

Proposed IUCN conservation assessment. Least Concern (LC). Although the species is only known from few collections these are widespread and there is no evidence that the species is confined to limestone, and there are no major threats.

Additional specimens examined. Sulawesi. Sungai Balambano, $20 \mathrm{~km}$ SW on road SoroakoWasupondo-Malili (c. $\left.2^{\circ} 36^{\prime} \mathrm{S} 121^{\circ} 14^{\prime} \mathrm{E}\right), 600 \mathrm{~m}, 26$ vi 1979 (fr), much disturbed primary forest c.30 m tall around waterfall, M.M.J. van Balgooy et al. 6010 (L); Matano-Meer (Nord ufer), 300 m, Konglomeratfelsen, xi 1929 (fr), G.K. Kjellberg 3938 (S); SW peninsula, NE of

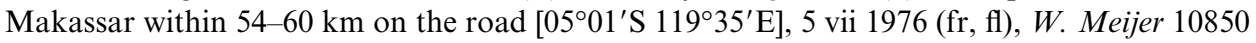
(MO).

The species is close to Paraboea havilandii (Ridl.) B.L.Burtt, but the glabrous or minutely pubescent calyx (not lanate) and ciliate corolla (not glabrous) easily distinguish it.

52. Paraboea meiophylla B.L.Burtt, Bot. J. Linn. Soc. 85: 29 (1982); Burtt, Notes Roy. Bot. Gard. Edinburgh 41: 433 (1984). - Type: Sarawak, 4th Division,

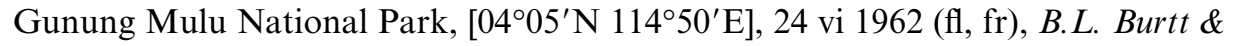
P.J.B. Woods 2265 (holo E; iso SAR). Fig. 31.

Perennial caulescent herb; stem terete, slender, arising from a woody caudix, up to $15 \mathrm{~cm}$ long excluding the inflorescence, internodes $0.5-2 \mathrm{~cm}$ long, with a whitish arachnoid or matted indumentum or glabrescent. Leaves in whorls of 3 or in rare cases opposite, shortly petiolate; petiole $0.5 \mathrm{~mm}$ long, sharing the same indumentum as the blades; blades narrow-elliptic to elliptic, $2-12 \times 0.6-5.2 \mathrm{~cm}$, apex acute, base attenuate, margin entire, upper surface glabrous or with some whitish arachnoid covering, lower surface with a white matted indumentum; veins smooth above, raised beneath, lateral veins c.7 pairs, tertiary venation invisible. Inflorescence terminal, paniculate, with a whitish matted indumentum throughout except on the pedicels and flowers; flowering stem up to $30 \mathrm{~cm}$ long, basal internodes elongated, 2$10 \mathrm{~cm}$ long; floral leaves dramatically reduced in size compared with the caulescent leaves, up to $3 \times 1 \mathrm{~cm} ; 3$ cymes from each node; cymes from the lowest axil $3-12 \mathrm{~cm}$ long, several-flowered; peduncle 1-6 cm long, peduncle bracts narrow-oblong, sepallike or up to 2 times as long as sepals; pedicel c. $7 \mathrm{~mm}$ long, glabrous. Calyx 1.5$2 \mathrm{~mm}$ long, 5-lobed to the base, lobes ovate. Corolla purple or pale mauve-blue, c. $9 \mathrm{~mm}$ long, $10 \mathrm{~mm}$ across when fully open; tube $1.5 \mathrm{~mm}$ long, limb 2-lipped; upper lip 2-lobed, lobes wide-ovate, c. $5 \times 5 \mathrm{~mm}$, lower lip c. $7 \mathrm{~mm}$ long, 3-lobed, middle lobe longer than the lateral lobes, \pm oblong, c. $3 \times 3.5 \mathrm{~mm}$, lateral lobes wide-ovate, c. $4.5 \times 5 \mathrm{~mm}$. Anthers yellow, transversely ellipsoid, c. $1.5 \times 3.5 \mathrm{~mm}$, coherent with each other at the apex and the base, opening in the centre of the anther locules, apex turned towards the gynoecium, dorsifixed; filaments inserted at the corolla base with 


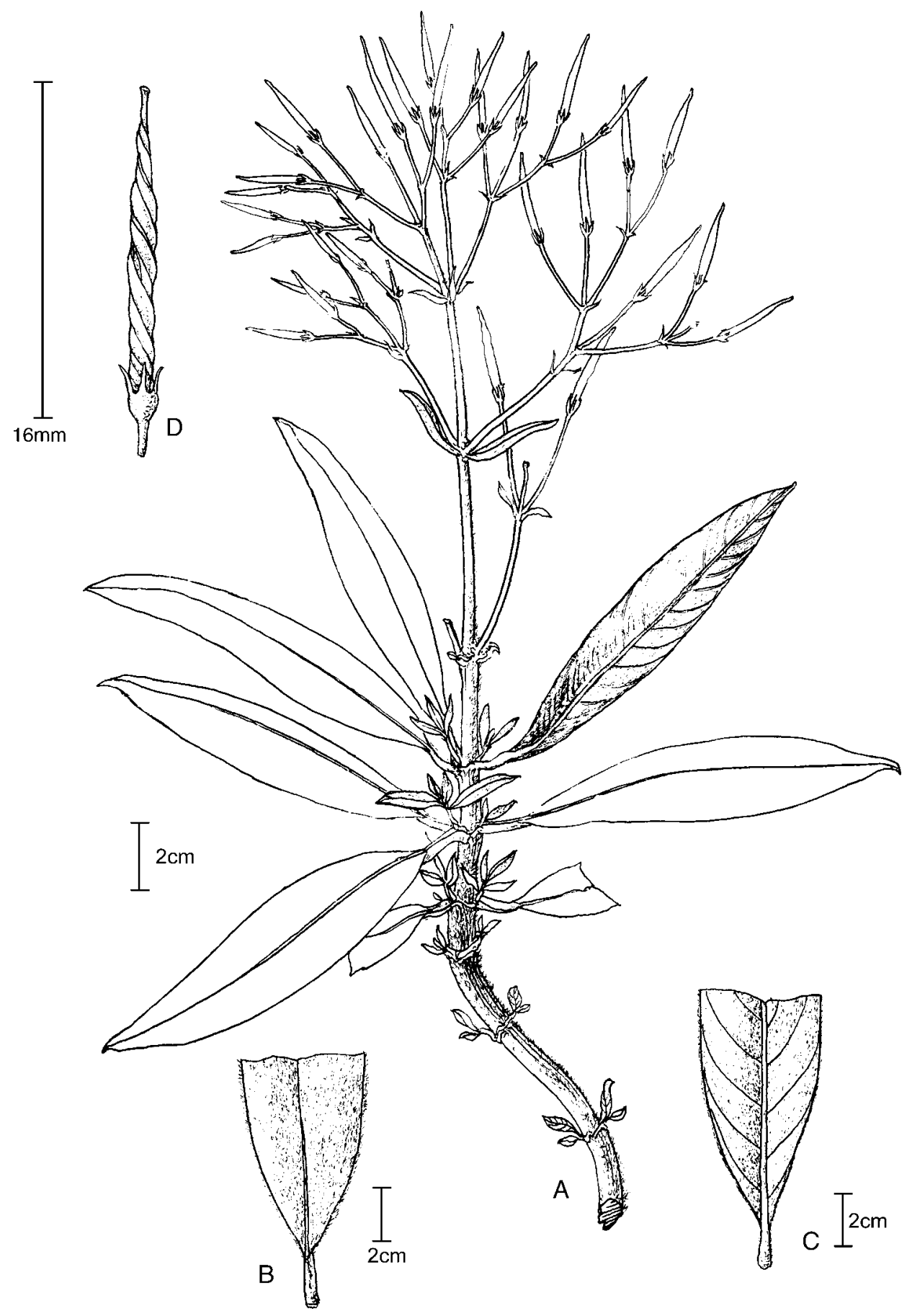

FIg. 31. Paraboea meiophylla B.L.Burtt. A, habit; B, upper leaf surface; C, lower leaf surface; D, fruit. 
a free part c. $3 \mathrm{~mm}$ long, crenate in the middle. Ovary ovoid, c. $2 \times 1 \mathrm{~mm}$, distinct from the style; style narrower, c. $5 \mathrm{~mm}$ long; stigma capitate, similar to style. Fruit a spirally twisted capsule, c. $1.5 \mathrm{~cm}$ long, $1.5 \mathrm{~mm}$ in diameter, glabrous. Seeds ellipsoid, $7 \times 2 \mathrm{~mm}$.

Distribution. Malaysia: Sarawak.

Habitat and ecology. On limestone.

Proposed IUCN conservation assessment. Least Concern (LC). The conservation assessment given reflects the fact that although this species is known from few collections they are all from Gunung Mulu National Park which is a World Heritage Site and well protected.

Additional specimens examined. Malaysia. Sarawak: 4th Division, Gunung Mulu National Park, S flank of Benarat Cliffs, facing Melinau on Limestone [04 ${ }^{\circ} 02^{\prime} \mathrm{N} 114^{\circ} 50^{\prime} \mathrm{E}$ ], 24 vi 1962 (fl, fr), B.L. Burtt \& P.J.B. Woods 2281 (E, SAR), 2282 (E, SAR), 2278 (E); Gunung Mulu

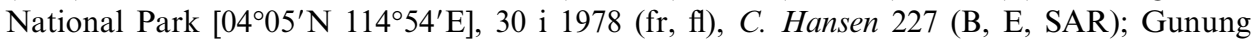

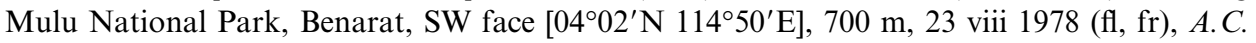
Jermy 14475 (E).

This species is close to Paraboea effusa B.L.Burtt, but differs in having a whitish (vs. yellowish-white or light brown) indumentum on the leaves and inflorescence and generally smaller leaves.

53. Paraboea minahassae (Teijsm. \& Binn.) B.L.Burtt, Kew Bull. 1948: 56 (1948); Burtt, Notes Roy. Bot. Gard. Edinburgh 41: 433 (1984). - Boea minahassae Teijsm. \& Binn., Tijdschr. Ned. Ind. 25: 415 (1863). - Didymocarpus minahassae (Teijsm. \& Binn.) H.O.Forbes, J. Linn. Soc., Bot. 19: 298 (1882). - Type: Celebes [Sulawesi], Prov. Minahassa, Likoepang [Likupang], Hab. Insulam, 1859-1860 (fl, fr), W.H. de Vriese \& J.E. Teijsmann 29 (lecto L, designated here). Fig. 32.

Perennial caulescent herb with a short stem $<20 \mathrm{~cm}$ long. Leaves oppositely congested at top of the stem or with internodes up to $2 \mathrm{~cm}$ long, long-petiolate; petiole $2-9 \mathrm{~cm}$ long, slightly enlarged at base and joining each other across the node, with a whitish or dark brown matted indumentum; blades more or less oblong-ovate, 3-7.5 $\times 1.5-3 \mathrm{~cm}$, c.1.5-2 times as long as wide, apex obtuse, base rounded to shallowly cordate, margin entire, upper surface arachnoid or glabrescent, lower surface with a whitish to dark brown matted indumentum; veins smooth above, raised beneath, lateral veins c.6 pairs, tertiary venation invisible. Inflorescence an axillary cyme, much longer than the leaves, c.10-15 $\times 2-5 \mathrm{~cm}$ with a few to many flowers; peduncle 7-14 cm long, with a matted indumentum throughout when young, the two primary bracts narrowly ovate, c.3 mm long; pedicels c.5-10 mm long, glabrous or with a minute glandular pubescence. Calyx lobes narrowly ovate, $2 \times$ $0.8 \mathrm{~mm}$, glabrous outside, minutely pubescent inside. Corolla c. $5 \mathrm{~mm}$ long, $6 \mathrm{~mm}$ across, glabrous; tube c.2-2.5 mm long, limb \pm 2-lipped, lower lip slightly longer 


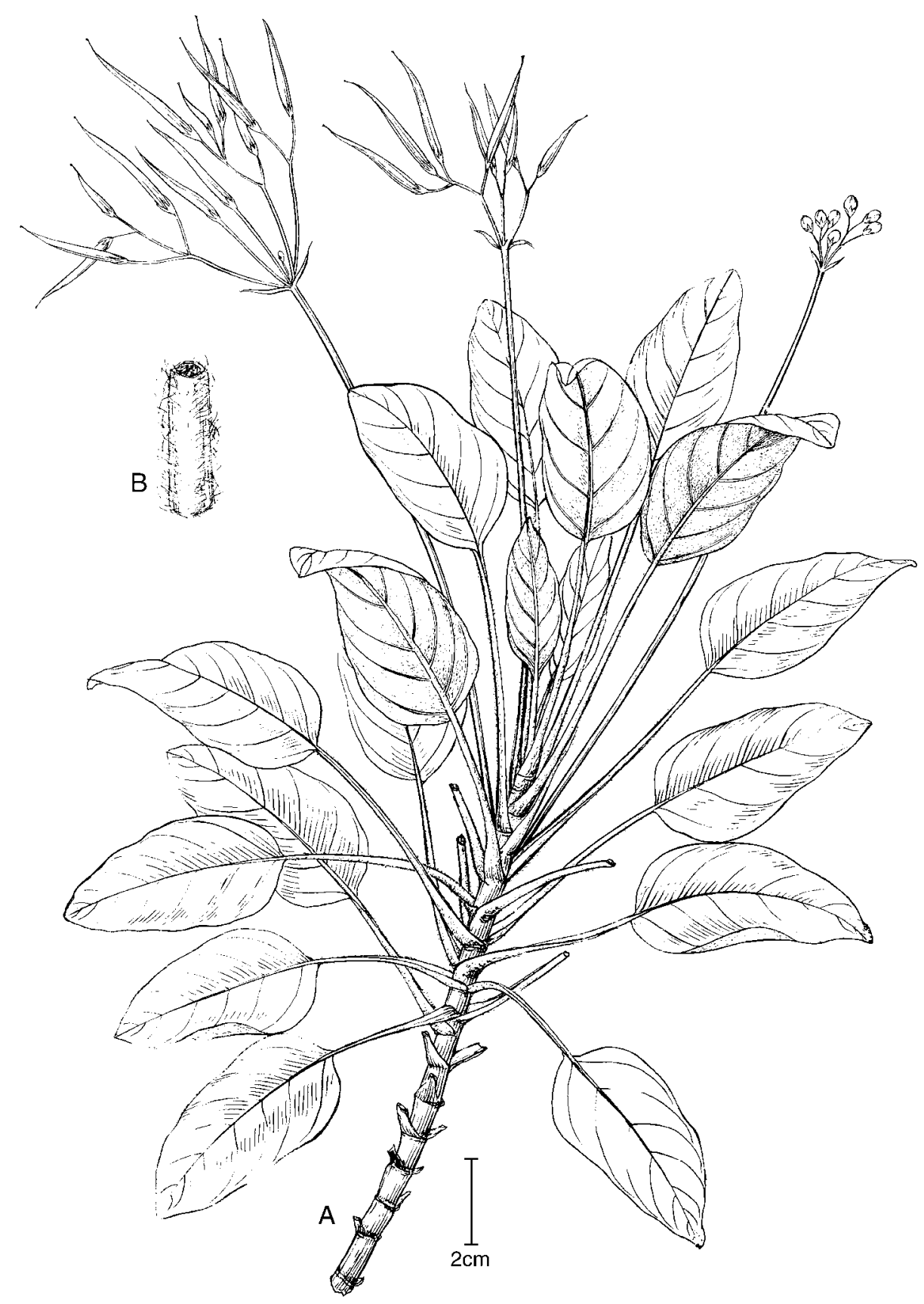

FIg. 32. Paraboea minahassae (Teijsm. \& Binn.) B.L.Burtt. A, habit; B, section of peduncle. 
than upper lip, 5 lobes of similar size and shape, rounded, c. $2.5 \times 3-3.5 \mathrm{~mm}$. Anthers \pm triangular, c. $2.5 \times 3 \mathrm{~mm}$, opening in the centre of the anther locules, dorsifixed; filaments $2.5 \mathrm{~mm}$ long, inserted at c. $1.5 \mathrm{~mm}$ from the corolla base, curved to make anther apex point towards gynoecium. Gynoecium $6.5 \mathrm{~mm}$ long; ovary $0.8 \mathrm{~mm}$ wide; style distinct, $0.3 \mathrm{~mm}$ wide; stigma larger than style. Fruit a linear non-twisted capsule, c. $2.5 \mathrm{~cm}$ long, glabrous, \pm curved like a sickle when mature. Seeds ellipsoid, $0.4 \times 0.2 \mathrm{~mm}$.

Distribution. Indonesia: Sulawesi.

Habitat and ecology. Unknown.

Proposed IUCN conservation assessment. Data Deficient (DD). This species has only been collected twice and these both long ago. We have no information on the habitat from which it was collected nor whether it was indeed from limestone.

Additional specimen examined. Indonesia. [Sulawesi:] prope Menado, Hort. Bogor. 5262 (BM).

Burtt (1984) listed syntypes for this name including 'prope Menado, Hort. Bogor. 5262 (BM)'. Here we lectotypify the name with de Vriese \& Teijsmann 29 as this collection is a complete plant from Minahassa. Forbes (1882) suggested the corolla of this species was $17 \mathrm{~mm}$ in diameter but we have seen no material approaching this size.

54. Paraboea minor (Barnett) B.L.Burtt, Notes Roy. Bot. Gard. Edinburgh 41: 433 (1984). - Boea minor Barnett, Nat. Hist. Bull. Siam Soc. 20: 19 (1961); Barnett, Kew Bull. 15: 255 (1961). - Type: Thailand, Songkhla, on Kaokao [07² $12^{\prime} \mathrm{N}$ 100³0'E], 29 ix 1929 (fl, fr), A.F.G. Kerr 17575 (lecto K, designated by Barnett, Kew Bull. 15: 255 (1961)) [cult. Bangkok]. Fig. 33.

Perennial small herb 10-30 cm tall (not including the inflorescence); stem 1.5-3 mm in diameter, with internodes 5-25 mm long, with a whitish matted indumentum. Leaves opposite, petiolate; petiole c. $1-4 \mathrm{~cm}$ long, with 2 narrow wings that join across the node, with a whitish matted indumentum; blades more or less elliptic, 2.5$10 \times 1.5-3.5 \mathrm{~cm}, 2-4$ times as long as wide, apex obtuse, base angustate, margin entire, upper surface with some arachnoid covering and then glabrescent, lower surface with a whitish or slight yellowish matted indumentum; veins smooth above, slightly raised beneath, lateral veins sparse, c.5 pairs, tertiary venation invisible. Inflorescences subterminal, cymose from the axils beneath the terminal bud, c.10$20 \mathrm{~cm}$ long, few-flowered and quite lax, more or less with a minute pubescence; peduncle 7-15 cm long, with 2 linear bracts c. $3 \mathrm{~mm}$ long; pedicels 10-20 mm long. Calyx green, 1.5-2 mm long, 5-lobed to the base, lobes ovate or narrowly so, appearing glabrous. Corolla blue, lower part inside whitish, campanulate, c. $1.3 \mathrm{~cm}$ across; tube c. $3 \mathrm{~mm}$ long, limb slightly 2-lipped; upper lip c.5 $\times 10 \mathrm{~mm}$, 2-lobed, lobes widely ovate, c. $5 \times 6 \mathrm{~mm}$, lower lip c. $7 \times 12 \mathrm{~mm}$, 3-lobed, middle lobe slightly longer than the lateral lobes, all three c. $5 \times 7 \mathrm{~mm}$. Anthers yellow, heart-shaped with 


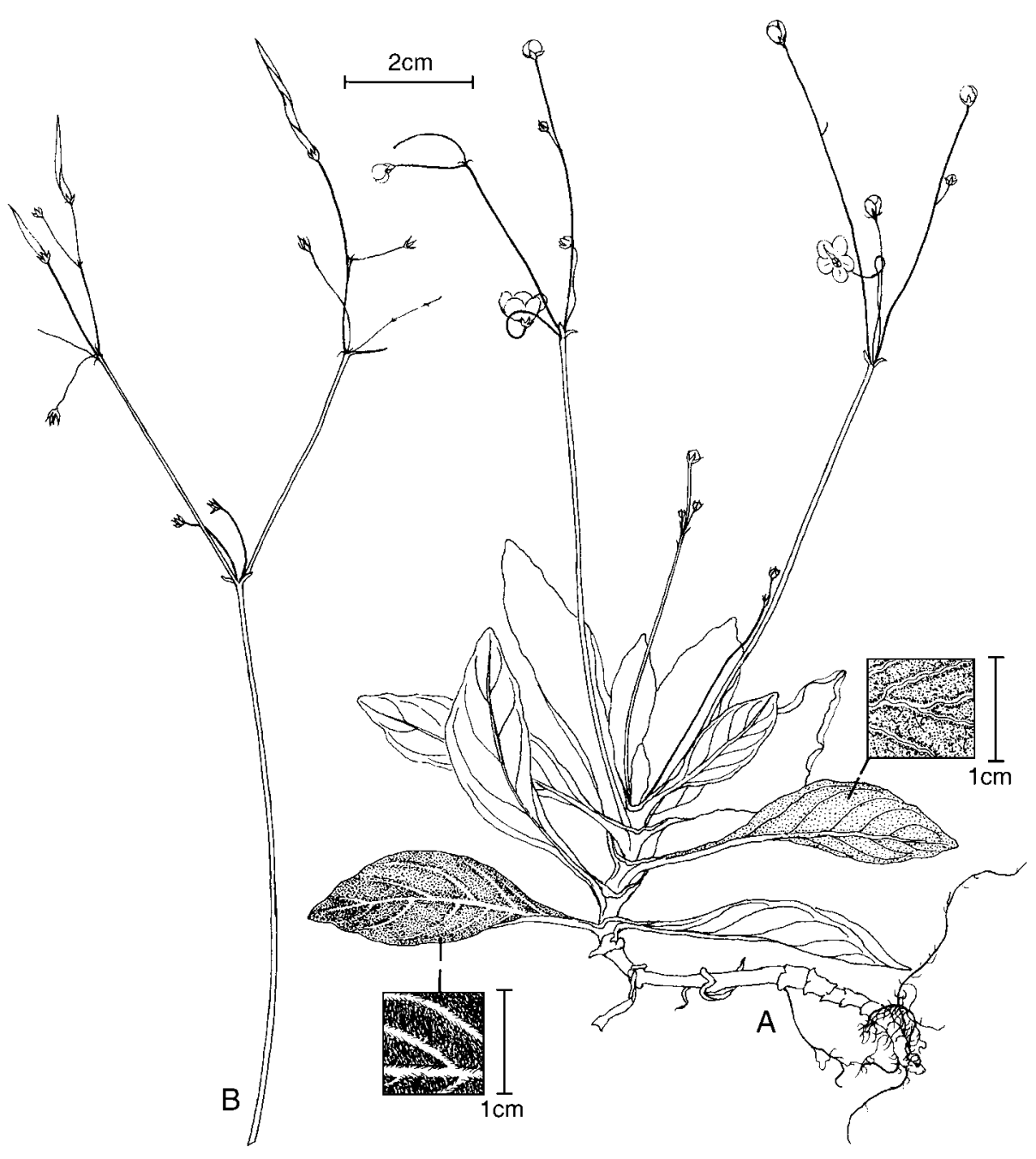

FIG. 33. Paraboea minor (Barnett) B.L.Burtt. A, habit; B, infructescence.

the apex pointing towards the gynoecium, coherent with each other at the apical part, c. $2 \times 3 \mathrm{~mm}$, opening in the centre of the anther locules, basifixed; filaments inserted at the corolla base with a free part c. $3 \mathrm{~mm}$ long. Gynoecium lilac, c. $8 \mathrm{~mm}$ long, $1.2 \mathrm{~mm}$ wide at the ovary base and $0.4 \mathrm{~mm}$ below the stigma; ovary narrowing into the style without a clear boundary between them; stigma much larger than style. Fruit a linear capsule, c. $2-2.5 \mathrm{~cm}$ long, $2.5 \mathrm{~mm}$ in diameter, glabrous, spirally twisted. Seeds ovoid or ellipsoid, $0.6-0.9 \times 0.25 \mathrm{~mm}$.

Distribution. Thailand.

Habitat and ecology. On limestone. 
Proposed IUCN conservation assessment. Least Concern (LC). This species has been collected at many sites over a wide area and there are no major threats. This species was, however, included in Pooma (2005) as threatened in Thailand.

Additional specimens examined. ThaILAND. Kanchanaburi: Kin Sayok, about $120 \mathrm{~km}$ NW of

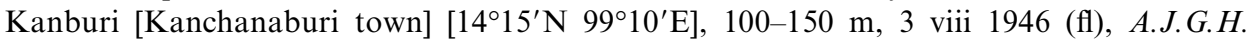

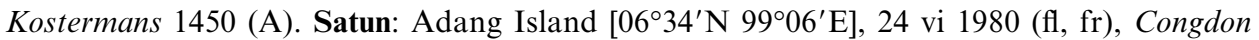
711a (A). Songkhla: Suan Toon waterfall at Khao Gaeo, c.10 km S of Songkhla, on the highway Songkhla-Chana, $07^{\circ} 04^{\prime} \mathrm{N} 100^{\circ} 32^{\prime} \mathrm{E}, 75 \mathrm{~m}, 1$ xi 1993, K. Larsen et al. 44180 (AAU); Boriphat Waterfall, $07^{\circ} 00^{\prime} \mathrm{N} 100^{\circ} 12^{\prime} \mathrm{E}, 100-200 \mathrm{~m}, 19$ x 1991, K. Larsen et al. 42391 (AAU); Boriphat Waterfall, 100 m, 29 x 1993, K. Larsen et al. 44124 (AAU); Boriphat Waterfall, SW of Hat Yai $\left[07^{\circ} 04^{\prime} \mathrm{N} 100^{\circ} 08^{\prime} \mathrm{E}\right]$, (fr, fl), W.M.M. Eddie 1 (E); Boriphat Waterfalls, SW of Hat Yai, Rattaphum District, 28 viii 1983? (fr, fl), W.M.M. Eddie 2 (E); Boriphat Waterfall, SW of Hat Yai, Rattaphum District, 28 viii 1983? (fr, fl), W. M. M. Eddie 3 (E); Boriphat Waterfall, Rattaphum District, 120-150 m, 18 xii 1979 (fr), T. Shimizu et al. T-27613 (BKF); Boriphat Waterfall, Rattaphum District [0704' $\left.\mathrm{N} 100^{\circ} 08^{\prime} \mathrm{E}\right], 120-150 \mathrm{~m}, 18$ xii 1979 (fr), T. Shimizu et al. T-27657 (BKF); Ton Nga Chang National Park $\left[07^{\circ} 05^{\prime} \mathrm{N}\right.$ 100¹0'E], 9 viii 1980 (fl), IN 7 (PSU); Muang District, Suan Toon Falls, 50 m, 5 x 1984 (fr), J.F. Maxwell 84-289 (PSU); Ton Nga Chang Reserve, Rattaphum District, 240 m, 2 x 1984 (fr), J.F. Maxwell 84-279 (A, PSU); Hat Yai District, Ton Nga Chang Falls, 9 x 1982 (fl), Piajaporn 9 (PSU); Ton Nga Chang waterfall, 100-250 m, 1 xi 1990, Larsen et al. 41034 (AAU); Ton Nga Chang Waterfall [Nat'l Park], 80-350 m, 19 xii 1979 (fr), T. Shimizu T-27712 (BKF); cult. in Bangkok, from Kaokao [07¹2' N 100³0'E], 22 x 1928 (fl), A.F.G. Kerr 16111 (ABD, K).

See discussion under Paraboea parviflora.

55. Paraboea minuta (Kraenzl.) B.L.Burtt, Notes Roy. Bot. Gard. Edinburgh 24: 47 (1962); Burtt, Notes Roy. Bot. Gard. Edinburgh 41: 433 (1984). - Didymocarpus minutus Kraenzl., Mitt. Inst. Bot. Hamburg 7: 88 (1927). - Type: [Indonesia, Kalimantan], West Borneo, Bukit Tilung, 700 m, 8 ii 1924 (fr, fl), H. Winkler 1488 (holo HBG).

Small perennial herb, lacking any arachnoid covering. Leaves (oppositely?) congested in a rosette, petiolate; petiole c. $5 \mathrm{~mm}$ long, with a brown matted indumentum; blades elliptic, 1.5-2.5 $\times 0.7-1 \mathrm{~cm}, \mathrm{c} .2-2.5$ times as long as wide, apex obtuse, base cuneate or widely so, in some rare cases appearing rounded, margin entire, upper surface with a dense pubescence, lower surface with a brown matted indumentum; veins smooth above, raised beneath, lateral veins c. 4 pairs, tertiary venation invisible. Infructescence axillary, umbelliform, longer than the leaf, c.5-8 cm long, fewflowered; peduncle slender, c. $4-5.5 \mathrm{~cm}$ long, glabrescent, bracts sepal-like, narrowly ovate, c. $0.5 \mathrm{~mm}$ long; pedicels c. $6 \mathrm{~mm}$ long. Calyx lobes ovate, $1 \times 0.4 \mathrm{~mm}$, with a minute pubescence outside, glabrous inside. Corolla c. $4.5 \mathrm{~mm}$ long, $8 \mathrm{~mm}$ across, \pm hairy outside, glabrous inside; tube c. $2 \mathrm{~mm}$ long, limb 2-lipped; upper lip c.2 $\times$ $4 \mathrm{~mm}$, with lobes rounded, $2 \times 2 \mathrm{~mm}$, lower lip much larger, c. $5 \times 8 \mathrm{~mm}$, with 3 lobes c. $2.5 \times 2.5 \mathrm{~mm}$. Anthers widely ovoid, c. $0.5 \times 1 \mathrm{~mm}$, opening in the centre of the anther locules, coherent only at the apex, basifixed; filaments $1.5 \mathrm{~mm}$ long, 
inserted at the corolla base, curved to turn anther apex horizontal. Gynoecium c. $4 \mathrm{~mm}$ long; ovary c. $1 \times 0.5 \mathrm{~mm}$; style long and distinct, $0.15 \mathrm{~mm}$ wide; stigma slightly larger. Fruit a linear non-twisted capsule, $0.5-1 \mathrm{~cm}$ long, glabrous, opening along the upper suture. Seeds not seen.

Distribution. Indonesia: Kalimantan. Known only from the type.

Habitat and ecology. Unknown.

Proposed IUCN conservation assessment. Critically Endangered (CR B1ab(ii,iii,v)) see conservation assessment section in introduction.

The species is characterised by its miniature appearance and the infructescence that has only 1-2 mature capsules.

56. Paraboea multiflora (R.Br.) B.L.Burtt, Notes Roy. Bot. Gard. Edinburgh 41: 433 (1984). - Boea? multiflora R.Br., Cyrtandreae 120 (1839), preprint from Benn., P1. Jav. Rav. 120 (1840). - Didymocarpus multiflorus Wall., Num. List. No. 793 (1829), nomen nudum. - Type: Bangladesh, Pundua, Sylhet Mt., [collected in early nineteenth century], F. De Silva in Wallich 793 (lecto BM, designated here; iso K, K-W). Fig. 34.

Boea flocculosa C.B.Clarke, Commelyn. Cyrtandr. Bengal. t.83 (1874). - Type: India, Khasia Hills, Hooker \& Thomson s.n. (lecto K, designated by Burtt (1984: 434)).

Boea multiflora R.Br. var. burmannica C.B.Clarke in A.DC. \& C.DC., Monogr. Phan. 5: 144 (1883). - Type: Burma, Moulmein, Parish 436 (lecto K, designated by Burtt (1984: 434)).

Boea microcarpa Drake, Bull. Soc. Philom. Paris, sér. 8, 2: 130 (1890). - Paraboea microcarpa (Drake) B.L.Burtt, Notes Roy. Bot. Gard. Edinburgh 41: 433 (1984).

- Type: Vietnam, Quang Ninh: Tangkeuin, près de Quang-Yen, [20 $56^{\prime} \mathrm{N}$ 106 $48^{\prime} \mathrm{E}$ ], 1885-1889 (fr), Balansa 4302 (holo P).

Boea thirionii H.Lév., Repert. Spec. Nov. Regni Veg. 11: 301 (1912). - Paraboea thirionii (H.Lév.) B.L.Burtt, Notes Roy. Bot. Gard. Edinburgh 41: 439 (1984). - Type: China, Kweichow, Gny-ken, chemin de la source, Esquirol 2699 (holo E). The type locality should be interpreted as: 'On the way from the starting place (Anlong?) to Ceheng'. Anlong (= Hing y Fou, i.e. Xing1yi4fu3) was then the locality of the church of the French missionaries. 'Gny-ken' is nowadays Ceheng, a town $\left(25^{\circ} 00^{\prime} \mathrm{N} 105^{\circ} 48^{\prime} \mathrm{E}\right) \mathrm{c} .40 \mathrm{~km}$ E of Anlong $\left(25^{\circ} 06^{\prime} \mathrm{N}\right.$ $\left.105^{\circ} 28^{\prime} \mathrm{E}\right)$.

Boea multiflora R.Br. var. villosa Pellegr. in Lecomte, Fl. Indo-Chine 4: 549 (1930). - Type: Laos, Savannakhet, haut vours de la Tch'epone a 500-600 m, dans les roches, E. Poilane 12188 (lecto P, designated here).

Boea reticulata Barnett, Nat. Hist. Bull. Siam Soc. 20: 20 (1961); Barnett, Kew Bull. 15: 256 (1961). - Type: Thailand, Chiengmai [Chiang Mai], Me Wang, Kerr 6356 (lecto K, designated by Barnett, Kew Bull. 15: 256 (1961); iso ABD). 


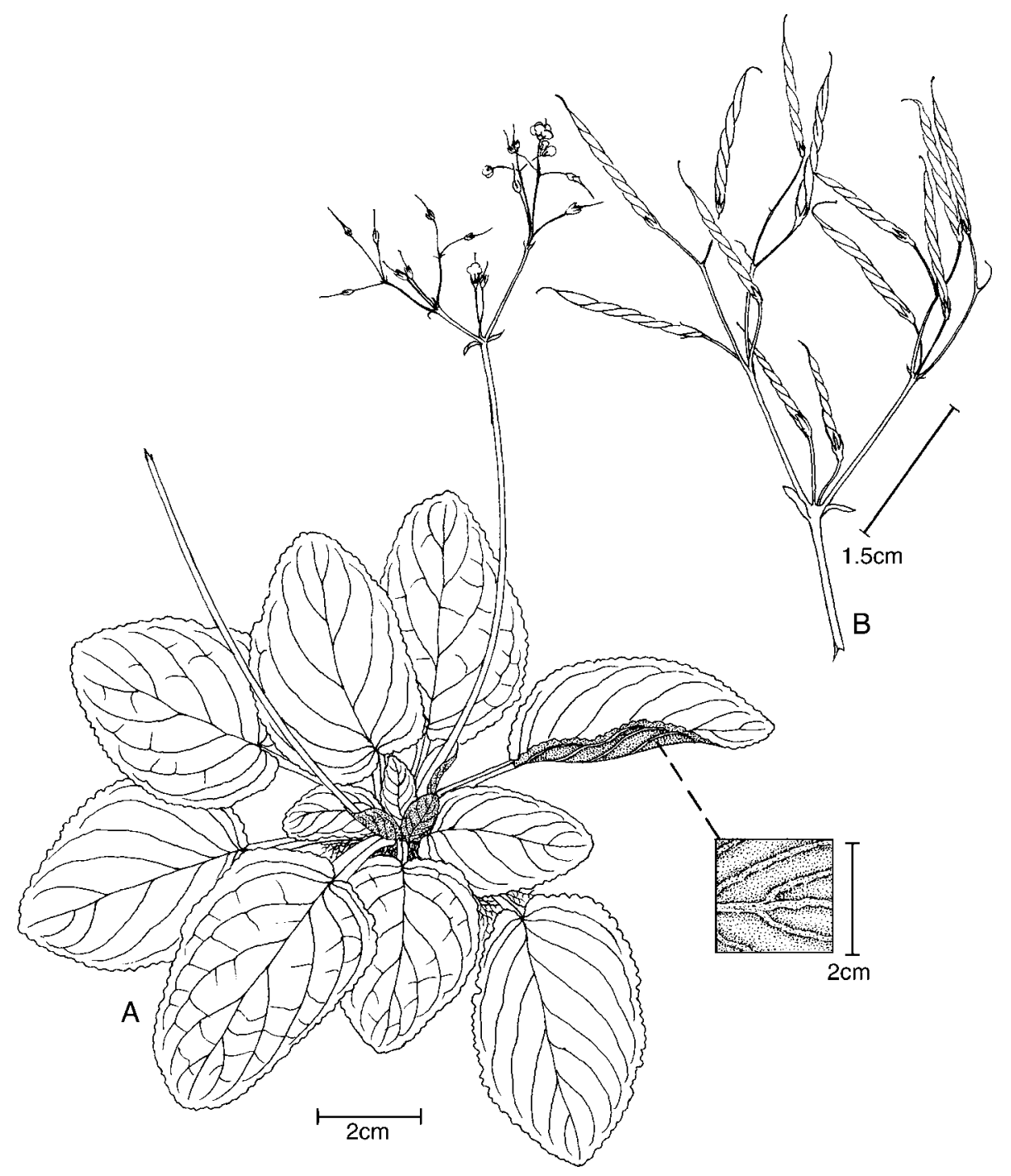

FIG. 34. Paraboea multiflora (R.Br.) B.L.Burtt. A, habit; B, infructescence.

\section{6a. Paraboea multiflora var. multiflora}

Perennial rosulate herb, with or without a woody stem or a rhizome; rhizome sometimes up to $20 \mathrm{~cm}$ long, $7 \mathrm{~mm}$ in diameter. Leaves congested in a rosette or sometimes cauline on an extending rhizome, petiolate; petiole $1-12 \mathrm{~cm}$ long, with the same indumentum as that on the blades; blades elliptic, more or less unequal, or rarely ovate, $4-22 \times 2.5-9 \mathrm{~cm}$, apex obtuse, base normally cuneate and in rare cases slightly cordate, margin more or less crenate, upper surface glabrescent or rarely with some indistinct pubescence, lower surface with a greenish or ferrugineous 
matted indumentum; veins smooth or scabrate above, raised beneath; lateral veins c.10-15 pairs, tertiary venation reticulate, with a thin or thick matted indumentum. Inflorescence axillary, cymose, 4-25 cm long, longer than or similar in length to the leaves, spreading, c.2-6 cm wide, many-flowered, with a matted indumentum except on the flower; peduncle $3.5-22 \mathrm{~cm}$ long, peduncle bracts inconspicuous; pedicels 2-7 $\mathrm{mm}$ long. Calyx 1-2.5 mm long, 5-lobed to the base, lobes ovate or narrowly so, c.1.3 $\times$ $0.7 \mathrm{~mm}$, glabrous inside, minutely greyish farinose or pubescent outside. Corolla white, c. $4.5 \mathrm{~mm}$ long, $8 \mathrm{~mm}$ across, with some minute pubescence; tube c. $1 \mathrm{~mm}$ long, limb indistinctly 2-lipped, 2 lobes of the upper lip and 3 lobes of the lower lip similar in size, wide-ovate, c. $2.5 \times 3 \mathrm{~mm}$. Anthers ellipsoid, c. $2 \times 2 \mathrm{~mm}$, distinctly yellowish or greenish farinose, not coherent with each other, basifixed, opening towards the top of the anther; filaments inserted at the corolla base with a free part c. $1 \mathrm{~mm}$ long. Ovary ovoid, c. $2.5 \times 1 \mathrm{~mm}$, whitish to greenish farinose, also present on the mature capsule; style distinct from the ovary, c. $3 \mathrm{~mm}$ long, glabrous; stigma capitate, not enlarged. Fruit a narrow-ovoid capsule, c.0.6-1.2 cm long, 1-2 $\mathrm{mm}$ in diameter, greyish to greenish farinose, spirally twisted. Seeds ovoid or ellipsoid, $3 \times 1.5 \mathrm{~mm}$.

Distribution. India, Bangladesh, Bhutan, Burma, Laos, Vietnam, Thailand and China.

Habitat and ecology. On limestone.

Proposed IUCN conservation assessment. Least Concern (LC). This variety has been collected at many sites over a wide area and there are no major threats.

Additional specimens examined. Bangladesh. East Bengal, (fr), Griffith 3843 (P, W) [East Bengal, Cult. in Roy. Bot. Gard. Kew (A)].

Burma. Moulmein [16 $\left.30^{\prime} \mathrm{N} 97^{\circ} 39^{\prime} \mathrm{E}\right], 1862$ ? (fr, fl), J. Lobb 436 (K).

China. vii 1911 (fl), J. Esquirol 2699 (E). Guangxi: (fr), L. Q. Chen 92733 (IBSC, photo US).

Guizhou: Lodian Xian (District Lofou) $\left[25^{\circ} 25^{\prime} \mathrm{N} 106^{\circ} 48^{\prime} \mathrm{E}\right], 1909$ (fr), J. Cavalerie 3620 (E, K, P).

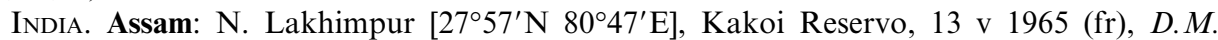

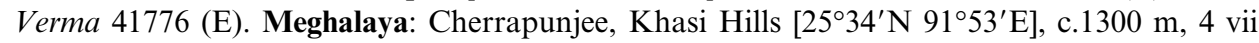
1952 (fl), T.R. Chand 5977 (L, MICH); Cherrapunjee, Khasi Hills, c.1300 m, 7 viii 1952 (fl), T.R. Chand 6394 (MICH); Sabhar Khasiyas [Khasi Hills], 1500 m, 3 x 1867 (fr), C.B. Clarke 5536 (L); E. Hiriy Bordge Khasia [Khasi Hills], 13 v 1886 (fr), C.B. Clarke 43839 (BM); Hab. Mount. Khasia [Khasi Hills], $4000 \mathrm{ft}(\mathrm{c} .1200 \mathrm{~m})$, J.D. \& T. Coll s.n. (C, L, P); Buxaduars [Khasi Hills], 700 m, 23 vi 1914 (fr, fl), R.E. Cooper 1026 (E); Mop, (fr), J.D Hooker 2 (GH, NY, US, W); Cherrapunjee, Khasi Hills, 1333 m, 27 vi 1952 (fl), W.N. Koelz 30371 (L, MICH).

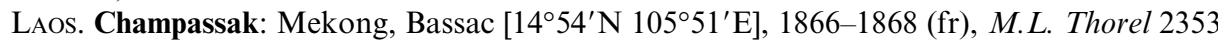
(P). Savannakhet: cours de la Tchepone [16 $\left.42^{\prime} \mathrm{N} 106^{\circ} 13^{\prime} \mathrm{E}\right], 500-600 \mathrm{~m}, 24$ vii 1925 (fl), E. Poilane $12188(\mathrm{P})$.

Thailand. s.1., 10 xi 1965 (fl), P. Sangkhachand 25 (BKF). Chiangmai: Me Wang (type locality of Boea reticulata Barnett), 400 m, 19 vii 1922 (lv), A.F.G. Kerr 6356 (ABD, K); $12 \mathrm{~km} \mathrm{~W}$ of Hot, Hot District $\left[18^{\circ} 12^{\prime} \mathrm{N} 98^{\circ} 34^{\prime} \mathrm{E}\right], 23$ ix 1958 (fl), K. Larsen et al. 5210 $(\mathrm{ABD}, \mathrm{C})$; Maeklang Falls, $50 \mathrm{~km}$ NW of Chiang Mai, Jawn Tong District, Doi Inthanon National Park [18 30'N 98 40’E], 430 m, 3 xi 1967 (fr), B.L. Burtt 5612 (E); Nam Tok 
Mae Klang, Jawar Tong District, Doi Inthanon National Park, 25 xi 1965 (fl), $S$. Phusomsaeng 5 (BKF, L); Payap, West of Muang Hot [W of Hot, Hot District], in rocky forest [ $\left.18^{\circ} 12^{\prime} \mathrm{N} 98^{\circ} 34^{\prime} \mathrm{E}\right], 23$ ix 1958 (fl), T. Sorensen et al. 5201 (BKF); Hot District, Awp Luang Nature Park, Doi Awp Luang, Mae Jam River, c. 15 km W of Hot, $550 \mathrm{~m}$, 23 x 1987, Maxwell 87-1281 (L). Lampang: Lampang [18²2'N 99³4'E], 420 m, 23 viii 1922 (fr), Winit 740 (BKF, K). Nakhon Nayok: s.1., 29 vii 1959 (fl), T. Sorensen et al. 7803 (C); Nang Rawng Waterfall, 100 m, 29 vii 1959 (fr, fl), T. Smitinand \& Floto 6106 (ABD, $\mathrm{BKF}, \mathrm{E}, \mathrm{K})$.

The species and its relatives constitute a natural group of plants which have been recognised as several different species (and varieties) from various different regions: Boea multiflora R.Br. var. multiflora (= Paraboea multiflora) from Bangladesh, Bhutan and India (Assam); Boea multiflora var. burmannica C.B.Clarke (= Paraboea multiflora) from Burma; Boea multiflora var. villosa Pellegr. (= Paraboea multiflora) from Laos (south) and adjacent Vietnam; Boea reticulata Barnett (= Paraboea multiflora) from Thailand; Boea evrardii Pellegr. (= Paraboea evrardii) from southern Vietnam; Boea thirionii H.Lév. (= Paraboea multiflora) from China; and Boea microcarpa Pellegr. (= Paraboea multiflora) from northern Vietnam. The distribution area of this group of plants is second only to that of Paraboea swinhoei. Despite such a large geographic area, a diverse range of habitats, and variable morphologies in habit and leaves, they are remarkably consistent in other characters such as the whitish or yellowish or greenish farinose indumentum on the anthers and the ovary which is retained on the mature capsule. The anther morphology of this species and its relatives is unique in the genus, with erect anthers, free from each other and opening towards the top of the anther, in sharp contrast to the majority of species in this genus that possess anthers coherent with each other and with their apex turned almost $90^{\circ}$ towards the gynoecium. They all have a rosulate habit and axillary cymose inflorescences.

The types of those names that are reduced to synonymy of Paraboea multiflora var. multiflora all have a similar leaf texture and inflorescence morphology (see discussion under Paraboea evrardii). There is some doubt over Paraboea microcarpa as the type material is poor but we have chosen to synonymise it here. The type has only 'after-season' capsules with remnant valves of a capsule retained from an earlier flowering season but without any remaining seeds. Pellegrin (1930) described the species as 'calyx glabrescent, ... fruit glabrous'. It is possible that he was confused by the old capsules, which, in general, lose their indumentum or attachments with time.

56b. Paraboea multiflora var. caulescens Z.R.Xu \& B.L.Burtt, Edinburgh J. Bot. 48: 7 (1991). - Type: Thailand, Kanchanaburi, near Neekey, near Wangka $\left[14^{\circ} 15^{\prime} \mathrm{N}\right.$ 99¹0'E], steep slopes of limestone, 150 m, rather rare, 13 vi 1946 (fr, fl), G. Den Hoed Exp. No. 946 (holo L).

Caulescent subshrub; stem woody, $>20 \mathrm{~cm}$ long. Leaves c. $7.5 \times 3 \mathrm{~cm}$, petiole c. $2-3 \mathrm{~cm}$ long. Inflorescence axillary, cymose, shorter than the leaves, c. $6 \mathrm{~cm}$ long, 
several-flowered. Calyx similar in length to corolla, c. $4.5 \mathrm{~mm}$ long, lobes $3.5 \times$ $0.8 \mathrm{~mm}$. Corolla white, c. $4 \mathrm{~mm}$ long, 4-5 mm across, campanulate, indistinctly 2lipped, or appearing almost actinomorphic, lobes c. $2 \times 2 \mathrm{~mm}$, rounded. Anthers suborbicular, c. $1.7 \times 1.7 \mathrm{~mm}$, slightly coherent at the apex. Other characters similar to Paraboea multiflora var. multiflora.

Distribution. Thailand. Known only from the type.

Habitat and ecology. On limestone.

Proposed IUCN conservation assessment. Critically Endangered (CR B1ab(ii,iii,v)) see conservation assessment section in introduction. This variety was also included in Pooma (2005) as threatened in Thailand.

This variety is easily distinguished from the type variety by the elongated woody stem and by the relatively long calyx.

57. Paraboea nervosissima Z.R.Xu \& B.L.Burtt, Edinburgh J. Bot. 48: 9 (1991). - Type: Peninsular Malaysia, Kelantan, Gua Musang, Ulu Kelantan [04 $53^{\prime} \mathrm{N}$ $101^{\circ} 58^{\prime} \mathrm{E}$ ], summit of limestone hill, common, 22 vi 1967 (fl, fr), F.S.P. Ng FRI 5568 (holo K; iso KEP, L). Fig. 35.

Perennial caulescent subshrub; stem woody, $>1 \mathrm{~m}$ tall, $1 \mathrm{~cm}$ in diameter or more, internodes $1-2 \mathrm{~cm}$ long, with a white or tawny matted indumentum when young and later glabrescent. Leaves in whorls of 3 or 4, petiolate; petiole c. $1-3 \mathrm{~cm}$ long, with the same indumentum as the stem; blades narrow-elliptic, 15-30 $\times 3-5 \mathrm{~cm}, 4-7$ times as long as wide, apex acute, base cuneate, margin more or less crenate, upper surface glabrous or pubescent, lower surface with a white or dull brown appressed matted indumentum; veins smooth above, very prominent beneath, lateral veins numerous, 18-45 pairs, forming an almost $90^{\circ}$ angle with the midrib, tertiary venation invisible. Inflorescence a terminal panicle, with a white or dull brown appressed matted indumentum throughout except on the flower; flowering stem 30-45 cm long, the most basal internodes not much elongated, c.1-5 cm long, appearing quite tight in the infructescence, floral leaves intermediate to vegetative leaves, gradually reducing in size upward; 3 or 4 cymes from each node, cymes c. $10 \mathrm{~cm}$ long or less, manyflowered; peduncle bracts narrow-ovate, c. $7 \times 2.5 \mathrm{~mm}$, pedicel bracts sepal-like; pedicels 5-15 mm long. Flowers with minute capitate pubescence on the calyx, the young corolla outside and the gynoecium, but glabrous on the stamens. Calyx 3-4 mm long, lobes ovate or narrowly so. Corolla mauve or purple, c. $1 \mathrm{~cm} \mathrm{long,} 1 \mathrm{~cm}$ wide; tube $2.5 \mathrm{~mm}$ long, limb 2-lipped; upper lip $3.5 \mathrm{~mm}$ long, 2-lobed, lobes wideovate, $3.5 \times 5 \mathrm{~mm}$, lower lip c. $8 \mathrm{~mm}$ long, 3-lobed, two lateral lobes $2 \times 3.5 \mathrm{~mm}$, wide-ovate, middle one $2.5 \times 2.5 \mathrm{~mm}$, rounded. Anthers yellow, transversely ellipsoid, $2 \times 5 \mathrm{~mm}$, coherent with each other at the apex and the base, opening in the centre of the anther locules, dorsifixed, apex turned towards the gynoecium; filaments c. $1.5 \mathrm{~mm}$ long, crenate on the two sides. Gynoecium $10 \mathrm{~mm}$ long, $1.2 \mathrm{~mm}$ 


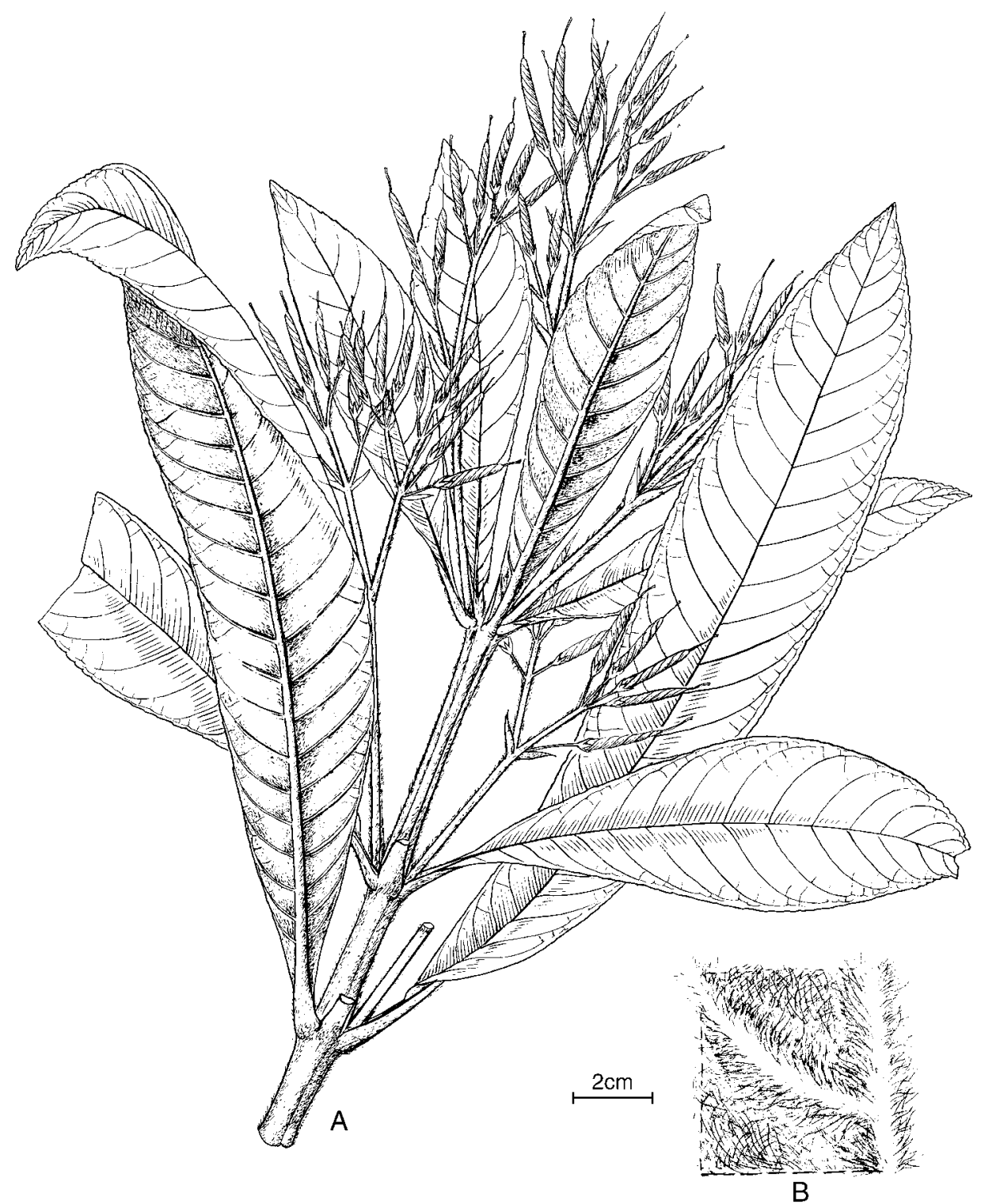

Fig. 35. Paraboea nervosissima Z.R.Xu \& B.L.Burtt. A, habit; B, indumentum on lower leaf surface.

wide, stigma capitate, a little larger than style. Fruit a spirally (extremely) twisted capsule, $1.5-2.5 \mathrm{~cm}$ long, $1.5-2 \mathrm{~mm}$ in diameter, with minute capitate pubescence. Seeds ellipsoid, $0.7 \times 0.25 \mathrm{~mm}$.

Distribution. Peninsular Malaysia. 
Habitat and ecology. On limestone.

Proposed IUCN conservation assessment. Least Concern (LC). This species has been collected at several sites over a wide area, some of them in protected areas, and there are no major threats.

Additional specimens examined. Malaysia. Pahang: Gua Tipus, 17 x 1927 (fl, fr), M.R. Henderson 19459a (K); Taman Negara, Gua Peningat, Pahang, 790 m, 14 vii 1970

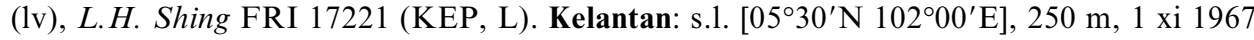
(fr), B.C. Stone 7449b (KLU); Gua Musang limestone hill summit [04 $53^{\prime} \mathrm{N} 101^{\circ} 58^{\prime} \mathrm{E}$ ], 250 m, 1 ix 1967 (fr), B.C. Stone 7307 (K, KEP, KLU, L); Gua Serai, Gua Musang limestone hill, 6 viii 1962 (fr), UNESCO Limestone Exp. 429 (L); W. Kelantan,

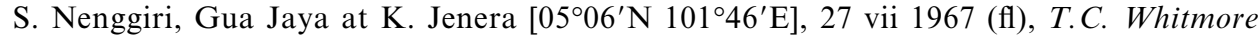
FRI 4251 (K, KEP, L).

This species is particularly distinct in its venation with numerous very prominent and horizontally spreading lateral veins on the lower leaf surface. It may be related to Paraboea caerulescens (Ridl.) B.L.Burtt with which it shares the same indumentum (minute capitate pubescence) on the calyx, ovary and fruit.

58. Paraboea neurophylla (Collett \& Hemsl.) B.L.Burtt, Notes Roy. Bot. Gard. Edinburgh 41: 434 (1984). - Didymocarpus neurophyllus Collett \& Hems1., J. Linn. Soc., Bot. 28: 102 (1880). - Type: Upper Burma, Shan Hills, Pinlong,

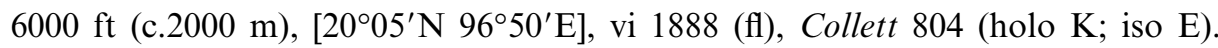
Fig. 36.

Perennial rosulate herb. Leaves more or less petiolate, petioles $0.5-3 \mathrm{~cm}$ long; blades obovate, (2.5-)6-12 × 1.5-7 cm, 2-4 times as long as wide, apex acute or rounded, base more or less angustate-rounded, margin crenate, upper surface glabrous, lower surface with a brown matted indumentum; veins smooth above, raised beneath, lateral veins c.6 pairs, tertiary venation distinctly reticulate. Inflorescences axillary, cymose, equal to or longer than the leaves, 7-12 cm long, 3-6 cm wide, manyflowered, with a matted indumentum; peduncle bracts and pedicel bracts narrowoblong, sepal-like (G.F. Li 61192 has larger peduncle bracts); pedicels c. $10 \mathrm{~mm}$ long. Calyx 1.5-3.5 mm long, 5-lobed, lobes ovate to narrowly oblong, 2-3.5 times as long as wide, with a matted indumentum or sparsely so outside, glabrous inside. Corolla violet; tube c.5 mm long, limb 2-lipped; upper lip 2-lobed, lobes wide-ovate, c. $2 \times$ $4 \mathrm{~mm}$, lower lip c.5 mm long, 3-lobed, middle lobe semi-circular, c. $3 \times 3.5 \mathrm{~mm}$, lateral lobes similar in shape, c. $2 \times 3 \mathrm{~mm}$. Anthers transversely ellipsoid, coherent with each other, opening at each end, apex pointing towards the gynoecium, dorsifixed; filaments c. $3 \mathrm{~mm}$ long, inserted at the base of the corolla, curved, but not swelling to form a knee in the middle, glabrous. Gynoecium c. $9 \mathrm{~mm}$ long, $1.2 \mathrm{~mm}$ wide at the ovary base; stigma not enlarged. Fruit a linear capsule, c. $1.5-2.5 \mathrm{~cm}$ long, glabrous, spirally twisted.

Distribution. Burma and China. 


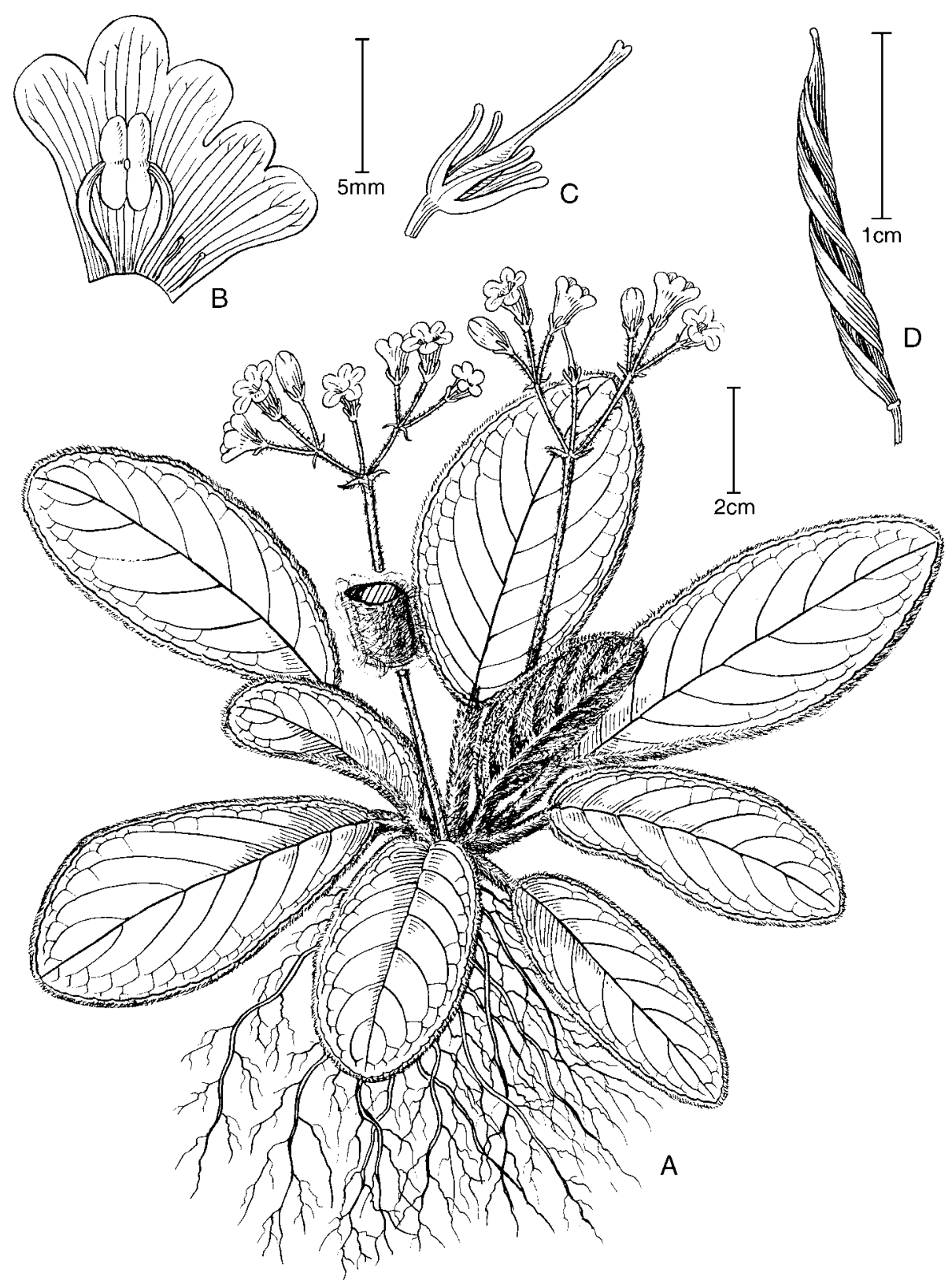

FIG. 36. Paraboea neurophylla (Collett \& Hemsl.) B.L.Burtt. A, habit; B, corolla opened out; $\mathrm{C}$, pistil and calyx; D, fruit. 
Habitat and ecology. On limestone.

Proposed IUCN conservation assessment. Least Concern (LC). This species has been collected at several sites over a wide area and there are no major threats.

Additional specimens examined. China. Eokou region de Kiao Kia, vi 1909 (fr), F. Ducloux 6068 (P); Suen-oui [?Xuen1wei1, NE Yunnan], 2600 m, (fl), R. P. Maire s.n. (P). Sichuan: 17 v 1957 (fl), G.F. Li 61192 (IBSC). Yunnan: 9 ix 1903 (fr), F. Ducloux 2279 (P); Kunming, San

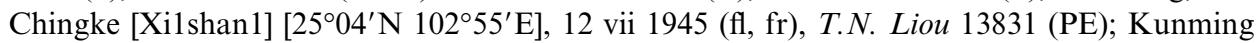
Xishan (West-Hill) $\left[25^{\circ} 04^{\prime} \mathrm{N} 102^{\circ} 55^{\prime} \mathrm{E}\right]$, (fr, fl), T.N. Liou 13970 (IBSC); Kunming, San Chingke [Xi1shan1], 16 vii 1946 (fr), T.N. Liou 20691 (PE); 2100 m, viii 17? (fl), O. Schoch 286 (K, US).

Burtt (1984) suggested that this species can be distinguished from Paraboea crassifolia by having petiolate leaves and blunter calyx lobes. In addition to these characters Paraboea neurophylla also has filaments which are smoothly curved, whilst in Paraboea crassifolia the filaments have a swollen knee.

G.F. Li (Li3 Gu02Feng1) 61192 (IBSC) is somewhat different from the specimens collected in Yunnan (China) and Burma in its longer inflorescence and more distinct peduncle bracts. However, the flower structure is the same and there is no swollen knee on the filaments.

59. Paraboea nutans D.Fang \& D.H.Qin, Acta Phytotax. Sin. 33(6): 604 (1995). - Type: China, Guangxi, Napo, D. Fang \& D.H. Qin 79634 (holo GXMI).

Perennial rosulate herb. Leaves petiolate; petiole $0.5-3 \mathrm{~cm}$ long, rarely almost absent, matted indumentum; blades obovate, (2.7-)4-16.5 $\times(1.5-) 2.8-8.8 \mathrm{~cm}$, apex rounded to obtuse, base attenuate or broadly cuneate, margin crenate or subentire, with some arachnoid covering above when young, greyish matted indumentum beneath; 7-11 pairs of lateral veins. Inflorescence axillary, cymose, shorter than the leaves, 1-2-branched, c.5-12-flowered, tomentose; peduncle 2.5$9 \mathrm{~cm}$ long, bracts oblong, 5-8 mm long. Flowers nodding. Calyx 5-lobed to the base, lobes oblong or oblong-lanceolate, 5-6 mm long, more or less tomentose outside. Corolla purplish-blue, $10-11 \mathrm{~mm}$ long, $15-16 \mathrm{~mm}$ in diameter, glabrous; tube c. $7 \mathrm{~mm}$ long, limb 2-lipped; upper lip 2-lobed, lobes $3 \mathrm{~mm}$ long, lower lip 3-lobed, $4 \mathrm{~mm}$ long, $7 \mathrm{~mm}$ wide, rounded. Anthers reniform, $3 \mathrm{~mm}$ long; filaments $2 \mathrm{~mm}$ long; staminodes 3, 1-1.5 mm long. Gynoecium glabrous; ovary c. $5 \mathrm{~mm}$ long; style 6-7 mm long; stigma capitate. Fruit a non-twisted capsule, $1-2.5 \mathrm{~cm}$ long, c.2 $\mathrm{mm}$ in diameter.

Distribution. China: Guangxi.

Habitat and ecology. Unknown.

Proposed IUCN conservation assessment. Critically Endangered (CR B1ab(ii,iii,v)) see conservation assessment section in introduction. The second specimen noted below is from the same locality. 
An additional specimen has been listed by the authors of the name but this has not been studied.

60. Paraboea paniculata (Ridl.) B.L.Burtt, Notes Roy. Bot. Gard. Edinburgh 41: 434 (1984). - Boea paniculata Ridl., J. Linn. Soc., Bot. 32: 519 (1896). - Type: Peninsular Malaysia, Selangor, Kuala Lumpur, Caves, i 1891, Kelsall 1970 (lecto SING, inflorescence on right hand side, designated here [the shoot on the left of the sheet belongs to $P$. verticillata]).

Perennial caulescent herb; stem woody, c.10-15 cm long, 1-1.5 cm in diameter. Leaves congested on the upper part of the stem, like a rosette, in whorls of 4-6, sessile, narrow-obovate, c. $10-25 \times 2-4.5 \mathrm{~cm}$, c. $3-6$ times as long as wide, apex acute or acuminate, base attenuate, margin entire, upper surface arachnoid, lower surface with a white or greyish-orange matted indumentum; veins smooth above, raised beneath, lateral veins 12-20 pairs, tertiary venation obscure. Inflorescence terminal, paniculate, not very long but very widely spreading, with some pubescence throughout; flowering stem 30-70 cm long, the most basal internodes c.2-15 cm long, floral leaves smaller than the vegetative leaves, up to $8 \times 1.5-2 \mathrm{~cm}, 5-6$ cymes from each node; cymes relatively long, up to $10-30 \mathrm{~cm}$, many-flowered; peduncle $10-15 \mathrm{~cm}$ long; peduncle bracts a little larger than or similar in size to the pedicel bracts, pedicel bracts sepal-like; pedicels 5-20 mm long. Calyx $4.7 \mathrm{~mm}$ long, 5-lobed to the base, lobes ovate or narrowly ovate, c. $3 \times 1.5 \mathrm{~mm}$, with glandular hairs outside, glabrous inside. Corolla blue-lilac, sky blue to mauve blue or magenta, $1.2 \mathrm{~cm}$ long, $1 \mathrm{~cm}$ across; tube $3 \mathrm{~mm}$ long, limb 2-lipped; upper lip $3 \mathrm{~mm}$ long, 2-lobed, lobes rounded, $3 \times 4 \mathrm{~mm}$, lower lip $8 \mathrm{~mm}$ long, 3-lobed, lateral lobes rounded, c. $4 \times 6 \mathrm{~mm}$, middle lobe $5 \times 4 \mathrm{~mm}$, glabrous inside, with some glandular hairs outside. Anthers transversely ellipsoid, c. $2.5 \times 5 \mathrm{~mm}$, coherent with each other, opening in the centre of the anther locules, dorsifixed, apex pointing towards the gynoecium, glabrous; filaments inserted at the corolla base, free part c. $3.5 \mathrm{~mm}$ long. Gynoecium c.7 mm long, with glandular pubescence; ovary c. $1.2 \mathrm{~mm}$ wide; style $4.5 \times 0.6 \mathrm{~mm}$; stigma capitate, larger than style. Fruit a spirally twisted capsule, narrow oblong or linear, 1.5-2.5 cm long, 1.5-3 $\mathrm{mm}$ in diameter, with dense brown pubescence. Seeds ovoid, 6-7 $\times 2 \mathrm{~mm}$.

Distribution. Peninsular Malaysia and Sumatra.

Habitat and ecology. On limestone.

Proposed IUCN conservation assessment. Least Concern (LC). This species has been collected at several sites over a wide area and there are no major threats.

Additional specimens examined. Indonesia. Sumatra: Aceh: Gunung Leuser Nature Reserve, Road Blang Kedjeren to Kotacane $\left[03^{\circ} 00^{\prime} \mathrm{N} 97^{\circ} 50^{\prime} \mathrm{E}\right], 800 \mathrm{~m}, 16$ iv 1975 (fl), W.J.J.O. de Wilde \& B.E.E. de Wilde-Duyfjes 16450 (L); Atjeh, Gajolanden from Kongke via Goempang, sandy slope along road, steep slope, 1000 m, 5 iii 1937 (fr, fl), C.G.G.J. van Steenis 9487 (A, K, L). 
Malaysia. Peninsular Malaysia: Perak: (fl), C. Curtis 3105 (K); Cheechoe Ngum Temple,

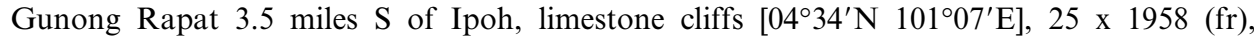
J. Sinclair 9872 (A, E, L, US). Selangor: Kanching Rock (= Bukit Takun), Kanching F.R. [03ำ $\left.18^{\prime} \mathrm{N} 101^{\circ} 41^{\prime} \mathrm{E}\right], 5$ xi 1940 (fl), S. Reid KEP51676 (KEP); Kanching Rock, Rawang [03 $\left.18^{\prime} \mathrm{N} 101^{\circ} 35^{\prime} \mathrm{E}\right], 400 \mathrm{~m}, 30 \times 1940$ (fl), C.C.L. Durant 56251 (KEP); Ulu Selangor, Kanching F.R., 533 m, 4 v 1947 (fr), KEP 63169 (KEP); Batu Caves, [03¹3'N 10141'E], 11 xi 1962 (fr), K. Jong \& Woods 4514 (E); Batu Caves, 233 m, 22 iv 1959 (fl, fr), KEP 79245 (KEP); Batu Caves, Selangor, 4 xi 1953 (fr), J. Sinclair 7833 (E, US).

This species is close to Paraboea caerulescens with which it shares the large terminal panicle with glandular pubescence on the cymes. However, Paraboea paniculata has a much wider panicle and the indumentum on the flower and the fruit is multicellular and glandular, while in $P$. caerulescens the panicle is narrower and the indumentum is of minute capitate glands, similar to a farinose pubescence.

61. Paraboea paramartinii Z.R.Xu \& B.L.Burtt, Edinburgh J. Bot. 48: 10 (1991). - Type: China, Yunnan, Pu'er, cliff, 4500 ft (c.1350 m), 1901? (fr), A. Henry 13394 (holo E; iso K, MO, US). Fig. 37.

Perennial rosulate herb with a short stem. Leaves petiolate; petiole 4-13 cm long with narrow wings which join at the base; blades thin papery, elliptic, c.13-26 × 6-12 cm, apex obtuse, base rounded, margin indistinctly crenate, upper surface glabrous, lower surface with a matted indumentum on the veins only; veins smooth above, raised beneath, lateral veins $10-15$ pairs, tertiary venation reticulate. Inflorescence a terminal panicle; flowering stem elongated, c. $22 \mathrm{~cm}$ long from the uppermost vegetative axil to the lowest fertile axil that bears a cyme, with one or two pairs of much reduced floral leaves measuring $30 \times 8 \mathrm{~mm}$ in this elongated part. Flowers not seen. Infructescence $30-40 \mathrm{~cm}$ long, nearly glabrous; peduncle bracts elliptic, c. $3 \mathrm{~mm}$ long, pedicel bracts sepal-like; pedicel 1-2 cm long. Calyx glabrous, c. $2.5-3 \mathrm{~mm}$ long, 5-lobed to the base, lobes narrow-oblong. Fruit a spirally twisted capsule, c. $3 \mathrm{~cm}$ long, glabrous. Seeds ellipsoid, $0.5 \times 0.2 \mathrm{~mm}$.

Distribution. China (Yunnan) and Thailand (?).

Habitat and ecology. On limestone.

Proposed IUCN conservation assessment. Data Deficient (DD). There is a taxonomic problem to be solved before a conservation assessment can be made (see note below).

Additional specimens examined. China. Yunnan: Szemao (Simao) $\left[22^{\circ} 50^{\prime} \mathrm{N} 101^{\circ} 02^{\prime} \mathrm{E}\right]$, W. Mt. forest, c.5000 ft (1500 m), 1900? (fr), A. Henry 12574B (part A) (K, NY).

Thailand. Chiangrai: Doi Tam $\mathrm{Tu} \mathrm{Pu}$, Saddle between peaks c.4 km west of Chiangrai

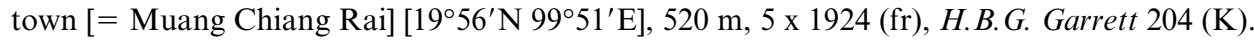

This species is similar to Paraboea martinii (H.Lév.) B.L.Burtt in having the same kind of inflorescence, but can be distinguished by the larger and thinner leaves and the glabrous inflorescence. 


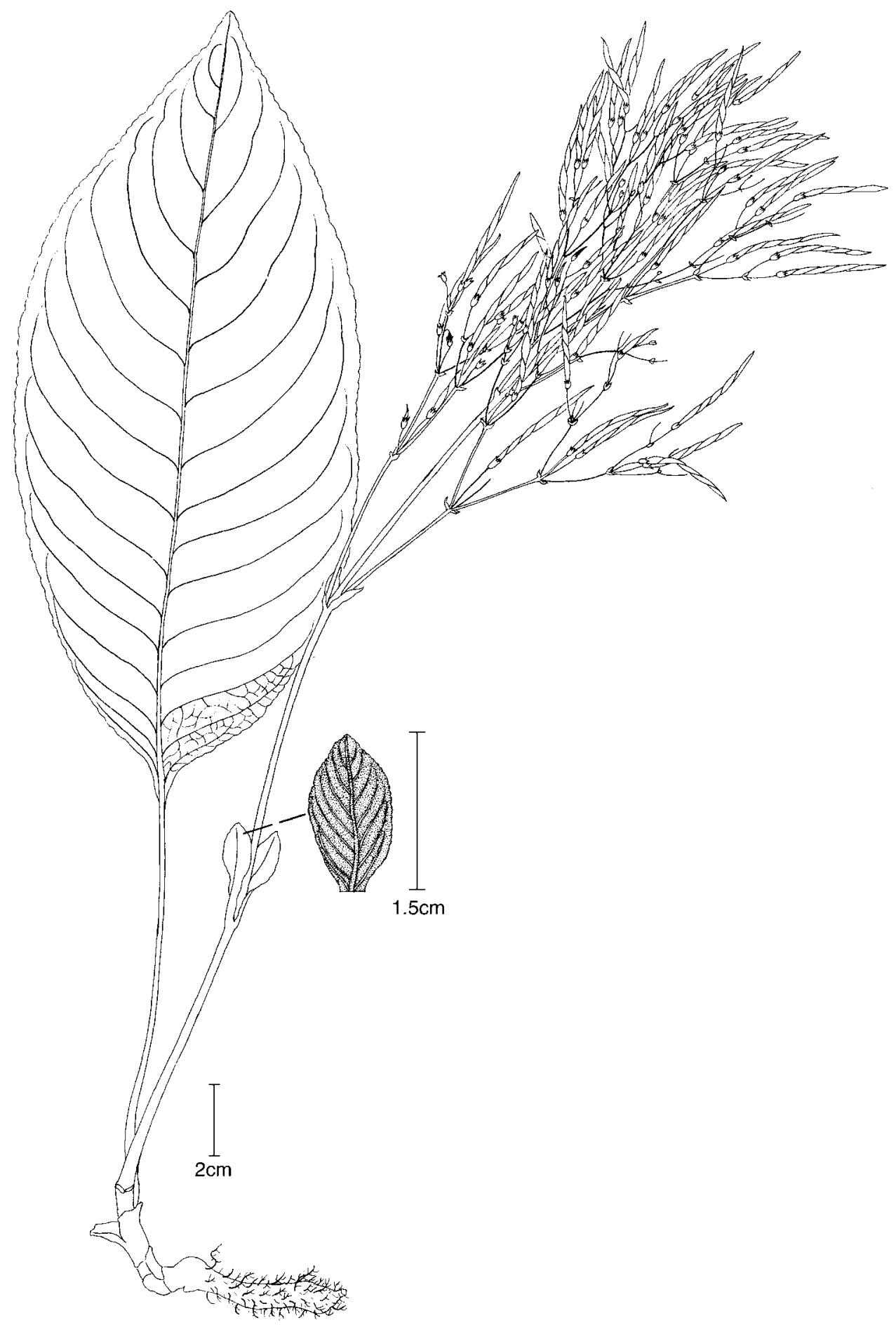

FIG. 37. Paraboea paramartinii Z.R.Xu \& B.L.Burtt. 
Part B of A. Henry 12574B (K) and H.B.G. Garrett 204 (K) [collected from Thailand, Doi Tam $\mathrm{Tu} \mathrm{Pu}$ may represent an undescribed species. They have a pubescence on the upper leaf surface and a subterminal cymose inflorescence rather than a terminal panicle. The material is insufficient for justifying a new name and they are here included under this species.

\section{Paraboea paraprimuloides Z.R.Xu, sp. nov.}

Paraboea primuloides affinis, sed foliis oblongis, c.5-18 $\times 3-9 \mathrm{~cm}$, et inflorescentibus glabris differt. - Type: Malaysia, Sarawak, Third Division, SE end Hose Mts, cliffs below Bukit Nibong, c.02 $06^{\prime} \mathrm{N} 113^{\circ} 42^{\prime} \mathrm{E}, 8$ viii 1967, Burtt \& Martin 4857 (holo E; iso E, SAR).

This species is close to Paraboea primuloides but the differences are: Leaves oblong, much larger, 5-18 $\times 3-9 \mathrm{~cm}$, with a brownish matted indumentum on the lower surface. Inflorescence 8-24 cm long; peduncle completely glabrous. Flower cream. Fruit obliquely spreading, not twisted, c. $3 \mathrm{~cm}$ long, seeds ovoid, $0.7 \times 0.22 \mathrm{~mm}$. The other characters are not significantly different from those of Paraboea primuloides.

Distribution. Malaysia: Sarawak. Known only from the type.

Habitat and ecology. Unknown.

Proposed IUCN conservation assessment. Critically Endangered (CR B1ab(ii,iii,v)) see conservation assessment section in introduction.

Burtt (1984) included the type collection for this new species in Paraboea paraboeoides. However, even though the material is not ideal, it does deserve specific status due to the differences noted above.

63. Paraboea parviflora (Ridl.) B.L.Burtt, Notes Roy. Bot. Gard. Edinburgh 41: 435 (1984). - Boea parviflora Ridl., J. Straits Branch Roy. Asiat. Soc. 44: 76 (1905).

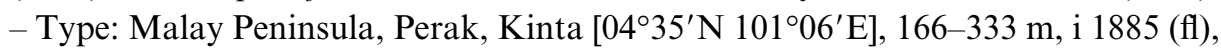
King's Collector 7108 (lecto K, designated here; iso SING). Fig. 38.

Perennial caulescent herb; stem c. $15 \mathrm{~cm}$ long, internodes 5-25 mm long, 2-5 mm in diameter, with a yellowish brown to ferrugineous matted indumentum. Leaves opposite, petiolate, those of a pair unequal in size; petiole $1-2.5 \mathrm{~cm}$ long, with the same indumentum as that on the stem; blades elliptic, 5-13 $\times 1.5-5 \mathrm{~cm}$, c. 3 times as long as wide, apex acute, base wide-cuneate to rounded, margin entire, upper surface with some arachnoid indumentum when young and glabrescent when older, lower surface with a yellowish brown to ferrugineous matted indumentum; veins smooth above, raised beneath, lateral veins c.8-12 pairs, tertiary venation invisible. Inflorescences subterminal, cymose, spreading and lax, few- to many-flowered, 15$25 \mathrm{~cm}$ long, with the same kind of indumentum as that on the stem but more or less glabrescent when mature; subordinate branches developing below the primary branches in the cyme; peduncles very slender, $12-14 \mathrm{~cm}$ long, $<1 \mathrm{~mm}$ in diameter, 


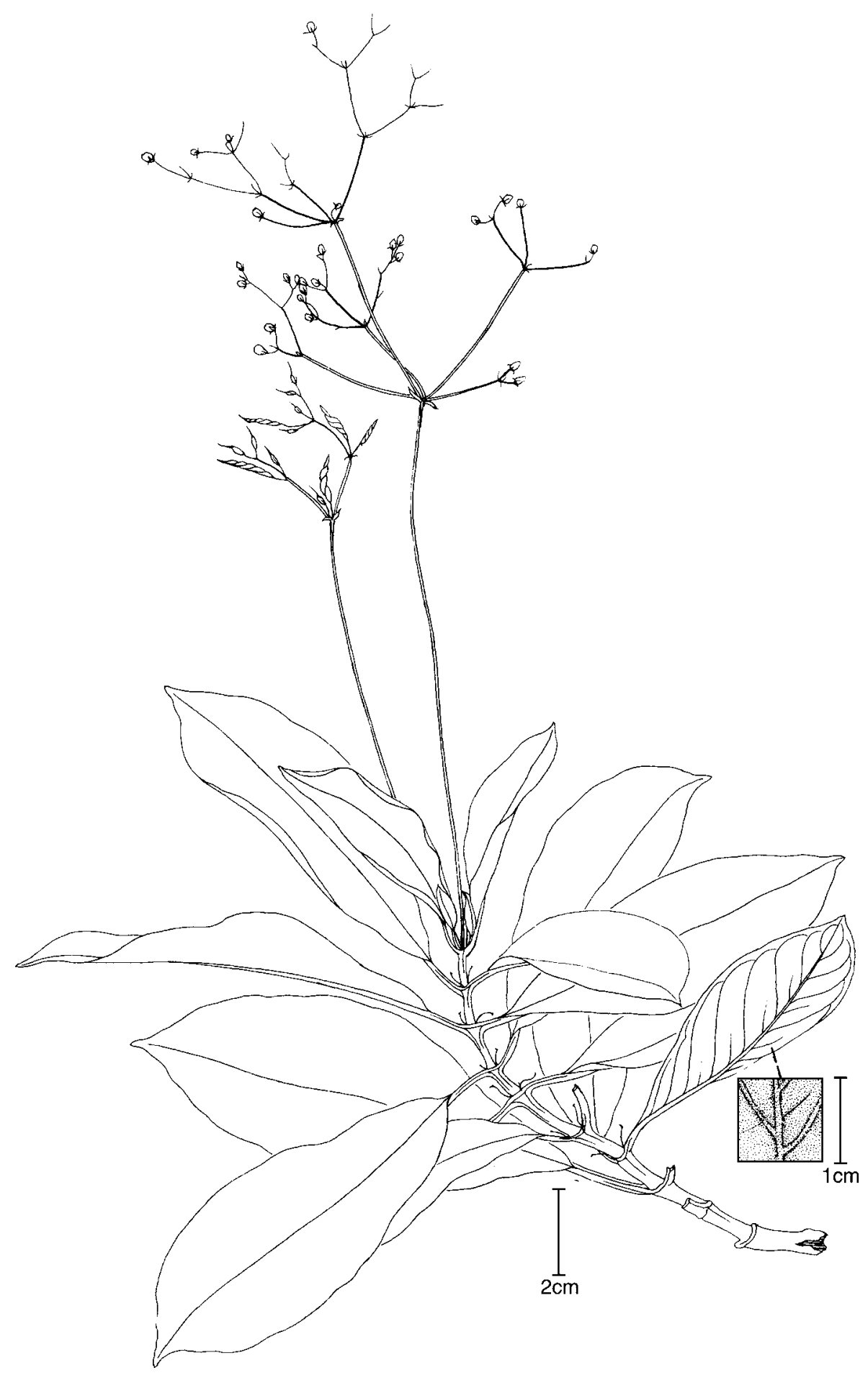

FIg. 38. Paraboea parviflora (Ridl.) B.L.Burtt. 
with 2 linear bracts c. $3 \mathrm{~mm}$ long; primary branches, subordinate branches, and secondary branches all rather delicate; pedicels even thinner than the peduncle, c.3-5 mm long. Calyx $1 \mathrm{~mm}$ long, 5-lobed to the base, lobes ovate or narrowly so, glabrous. Corolla white, c. $3 \mathrm{~mm}$ long, $3 \mathrm{~mm}$ across; tube c. $1.5 \mathrm{~mm}$ long, limb 2-lipped; upper lip not visibly 2-lobed, widely ovate, c. $1 \times 1.5 \mathrm{~mm}$, lower lip with 3 lobes of similar size and shape, glabrous. Anthers transversely ellipsoid (reniform), c. $1 \times 2 \mathrm{~mm}$, coherent at the apex, opening in the centre of the anther locules, apex turned towards the gynoecium, dorsifixed; filaments inserted at the corolla base with a free part c. $2 \mathrm{~mm}$ long. Ovary ovoid, c. $1.5 \times 1 \mathrm{~mm}$; style distinct from the ovary, c. $3 \mathrm{~mm}$ long, much thinner than the ovary; stigma oblique, glabrous. Fruit a linear capsule, $0.8 \mathrm{~cm}$ long, $0.6 \mathrm{~mm}$ in diameter, glabrous, spirally twisted. Seeds ellipsoid, c. $0.4 \times 0.15 \mathrm{~mm}$.

Distribution. Peninsular Malaysia.

Habitat and ecology. On limestone.

Proposed IUCN conservation assessment. Least Concern (LC). Although this species is known from relatively few collections they are almost all from protected areas and there are no major threats.

Additional specimens examined. Malaysia. Perak: Gunong Tempurong [04⒉ $\left.5^{\prime} \mathrm{N} 101^{\circ} 06^{\prime} \mathrm{E}\right]$, 266-566 m, 13 viii 1959 (fr), B. Allen \& Kadim 502MK (E, SING); Ayer Hangat, Ipoh

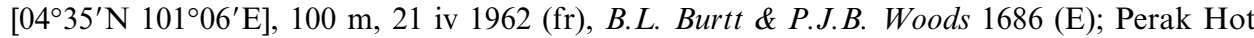
Springs [= Ayer Hangat], xii 1895 (fl), C. Curtis 3134 (SING).

The inflorescence structure and the flower morphology of this species suggest an affinity with Paraboea minor (Barnett) B.L.Burtt. However, the latter species does not normally have subordinate branches in the cymes and the peduncle is much thicker. Paraboea parviflora is characterised by the delicate peduncle and branches of the cyme as well as the miniature flowers and capsules. The anisophyllous leaves are also distinctive for this species. B.L. Burtt \& P.J.B. Woods $1686(\mathrm{E})$ is unusual for the species in its very narrow leaves.

64. Paraboea patens (Ridl.) B.L.Burtt, Notes Roy. Bot. Gard. Edinburgh 41: 435 (1984). - Boea patens Ridl., J. Linn. Soc., Bot. 32: 520 (1896). - Type: Thailand, Punga [Phangnga] $\left[08^{\circ} 32^{\prime} \mathrm{N} 98^{\circ} 28^{\prime} \mathrm{E}\right.$ ], collected in ii 1893, flowered in viii 1893 (in cultivation), Curtis s.n. (holo SING). Fig. 39.

Perennial rosulate herb with very short but stout stem. Leaves opposite, congested in a rosette, with very short petiole, leaf bases forming auricle around the node; blades oblong-elliptic, c.8-15 × 3-7 cm, c.2 times as long as wide, apex obtuse to rounded, base wide-cuneate, margin shallowly serrate, upper surface with a dense pubescence, lower surface with matted indumentum; veins obscure above, raised beneath, lateral veins c.7-10 pairs, tertiary venation reticulate. Inflorescence a subterminal cyme, appearing terminal, $30-70 \mathrm{~cm}$ long, spreading to $40 \mathrm{~cm}$ wide, with c. 4 orders of 


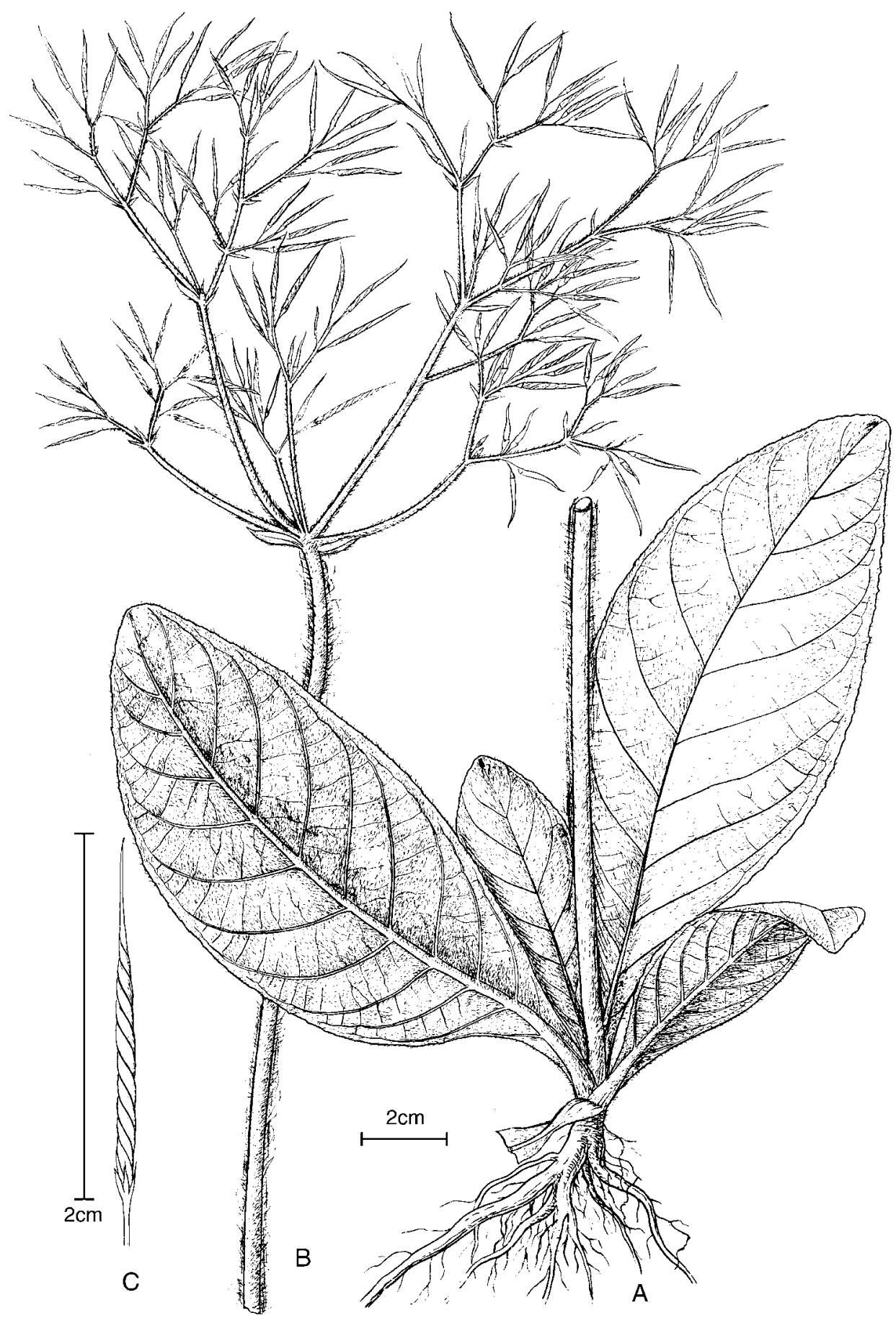

FIg. 39. Paraboea patens (Ridl.) B.L.Burtt. A, habit; B, infructescence; C, fruit. 
branching, many-flowered, quite lax, subordinate branches developing below or between the two primary branches on top of the peduncle, with a matted indumentum throughout up to the pedicel; peduncles $20-55 \mathrm{~cm}$ long, stout, with bracts oblong-ovate, c. $10 \times 5 \mathrm{~mm}$; pedicels slender, 2-5 $\mathrm{mm}$ long, normally glabrescent or with minute sessile glands, with bracts sepal-like. Calyx 5-lobed to the base, lobes narrowly ovate, c. $1 \times 0.3 \mathrm{~mm}$, with minute hairs outside. Corolla c. $6 \mathrm{~mm}$ across with indistinct tube, limb 2-lipped; upper lip c. $2.5 \times 3.5 \mathrm{~mm}, 2$-lobed, lower lip c. $2.5 \times 5 \mathrm{~mm}, 3$-lobed, 5 lobes all quite similar, rounded or wide-ovate, c. $2 \times 2.5 \mathrm{~mm}$. Anthers narrowly ellipsoid, c. $1.3 \times 2 \mathrm{~mm}$, apex pointing towards the gynoecium, coherent with each other, opening at each end, dorsifixed; filaments inserted at c. $1 \mathrm{~mm}$ from the corolla base with a free part c. $1.5 \mathrm{~mm}$ long, slightly enlarged in the middle. Ovary ovoid, c. $1.8 \times 0.6 \mathrm{~mm}$; style c. $3 \mathrm{~mm}$ long, $0.3 \mathrm{~mm}$ wide; stigma capitate. Fruit a very slender delicate capsule, 1-2.5 cm long, c. $0.6 \mathrm{~mm}$ in diameter, glabrous, spirally twisted. Seeds compressed, ovoid, $0.5 \times 0.2 \mathrm{~mm}$, brown.

Distribution. Thailand.

Habitat and ecology. On limestone.

Proposed IUCN conservation assessment. Data Deficient (DD). Many of the limestone areas in Phangnga are protected but not all. Without better locality information it cannot be ascertained whether this species is in the protected area or not.

Additional specimens examined. Thalland. Phangnga: Kasoom $\left[08^{\circ} 24^{\prime} \mathrm{N} 98^{\circ} 27^{\prime} \mathrm{E}\right]$, on limestone rock, C. Curtis 3218 (collected in 1896) (K, SING); Panga [Phangnga] [08 $32^{\prime} \mathrm{N}$ 98²8'E], 12 xii 1918 (fr), M. Haniff \& Nur 4026 (SING).

This species is characterised by its subterminal cyme which develops subordinate branches below and between the two primary branches on top of the peduncle. Paraboea divaricata shares the same inflorescence structure (subterminal cyme with subordinate branches) but has leaves in whorls.

65. Paraboea peltifolia D.Fang \& L.Zeng, Acta Phytotax. Sin. 33(6): 606 (1995).

- Type: China, Guangxi, Mashan, D. Fang \& L. Zeng 31379 (holo GXMI).

Perennial caulescent herb; stems 2-7 cm tall, 5-10 mm wide. Leaves alternate (?); petiole 1-9 cm long, with a matted indumentum; blades obovate, oblanceolate, spathulate or subpandurate, 6-33.5 × 3-14.3 cm, apex rounded or obtuse, base peltate-auriculate, rarely cordate, subtruncate or cuneate, margin irregularly crenateserrate, with some arachnoid covering when young above, with a greyish matted indumentum beneath; lateral veins 11-18 pairs. Inflorescence axillary, cymose, appearing umbellate, 1-2-branched, c.2-15-flowered; peduncle 4-6 cm long, lanate, bracts lanceolate-triangular, 2-3(-4) $\mathrm{mm}$ long. Calyx c.3.5 mm long, 2-lipped, lanate outside; upper lip 2-dentate, segments c.0.7 mm long, lower lip 3-dentate, segments 
c. $2 \mathrm{~mm}$ long. Corolla white, $14 \mathrm{~mm}$ long, $15 \mathrm{~mm}$ in diameter, glabrous; tube $7 \mathrm{~mm}$ long, limb 2-lipped; upper lip 2-lobed, $5 \mathrm{~mm}$ long, lower lip 3-lobed, $7 \mathrm{~mm}$ long, lobes $7 \mathrm{~mm}$ wide, apex rounded, middle lobe slightly retuse. Anthers reniform, $3 \mathrm{~mm}$ long; filaments $3 \mathrm{~mm}$ long; staminodes 2, $2 \mathrm{~mm}$ long. Gynoecium sparsely lanate; ovary c. $5 \mathrm{~mm}$ long; style $7 \mathrm{~mm}$ long; stigma shortly capitate. Fruit not twisted, $1-3.6 \mathrm{~cm}$ long, $2-3 \mathrm{~mm}$ in diameter.

Distribution. China: Guangxi.

Habitat and ecology. Unknown.

Proposed IUCN conservation assessment. Critically Endangered (CR B1ab(ii,iii,v)) see conservation assessment section in introduction.

A distinctive species in the non-twisted fruit group from China by its large, peltate leaves.

66. Paraboea primuloides Z.R.Xu, nom. nov. - Didymocarpus primuloides Kraenzl., Mitt. Inst. Bot. Hamburg 7: 90 (1927), non (Miq.) Maxim. (1876). - Type: [Indonesia, Kalimantan], West Borneo, auf dem Bukit Mulu, c.1100 m, 2 xii 1924 (fl, fr), H. Winkler 522 (holo HBG; iso E). Fig. 40.

Perennial rosette-like herb without a distinct stem. Leaves oppositely congested in a rosette, with a very short petiole c. $0.5 \mathrm{~cm}$ long; blades more or less elliptic, c.3-5 $\times$ 1.5-2 cm, c.1.5-2 times as long as wide, apex obtuse, base cuneate or widely so, margin entire, upper surface with a thin but dense layer of whitish matted indumentum, which is thicker and tighter on the lower surface; veins smooth above, raised beneath, lateral veins c.5-6 pairs, tertiary venation invisible. Inflorescence of axillary cymes, longer than the leaves, c. $8-14 \mathrm{~cm}$ long, few-flowered; peduncle c.6-12 cm long, whitish with a matted indumentum; two primary bracts narrowly ovate, c. $4 \mathrm{~mm}$ long, with minute sessile glands inside and glabrous outside; pedicels c. $10 \mathrm{~cm}$ long, glabrous, bracts on pedicels with minute sessile glands inside and glabrous outside. Calyx lobes narrowly ovate, $3 \times 0.8 \mathrm{~mm}$, \pm with minute sessile glands inside. Corolla violet (?), \pm with the same kind of glands inside and outside, c. $15 \mathrm{~mm}$ across when open, with a short tube, 2-lipped; upper lip suborbicular, c. $6 \mathrm{~mm}$ long and wide, lower lip similar in shape but appearing slightly smaller. Stamens short and thick, anthers \pm widely ovate, $1.5 \times 2.2 \mathrm{~mm}$, opening in the centre of the anther locules; filaments $2.5 \mathrm{~mm}$ long. Gynoecium $6 \mathrm{~mm}$ long; ovary $1 \mathrm{~mm}$ wide. Fruit a linear non-twisted capsule up to $2.5 \mathrm{~cm}$ long, glabrous. Seeds not seen.

Distribution. Indonesia: West Kalimantan. Known only from the type.

Habitat and ecology. Unknown.

Proposed IUCN conservation assessment. Critically Endangered (CR B1ab(ii,iii,v)) see conservation assessment section in introduction. 

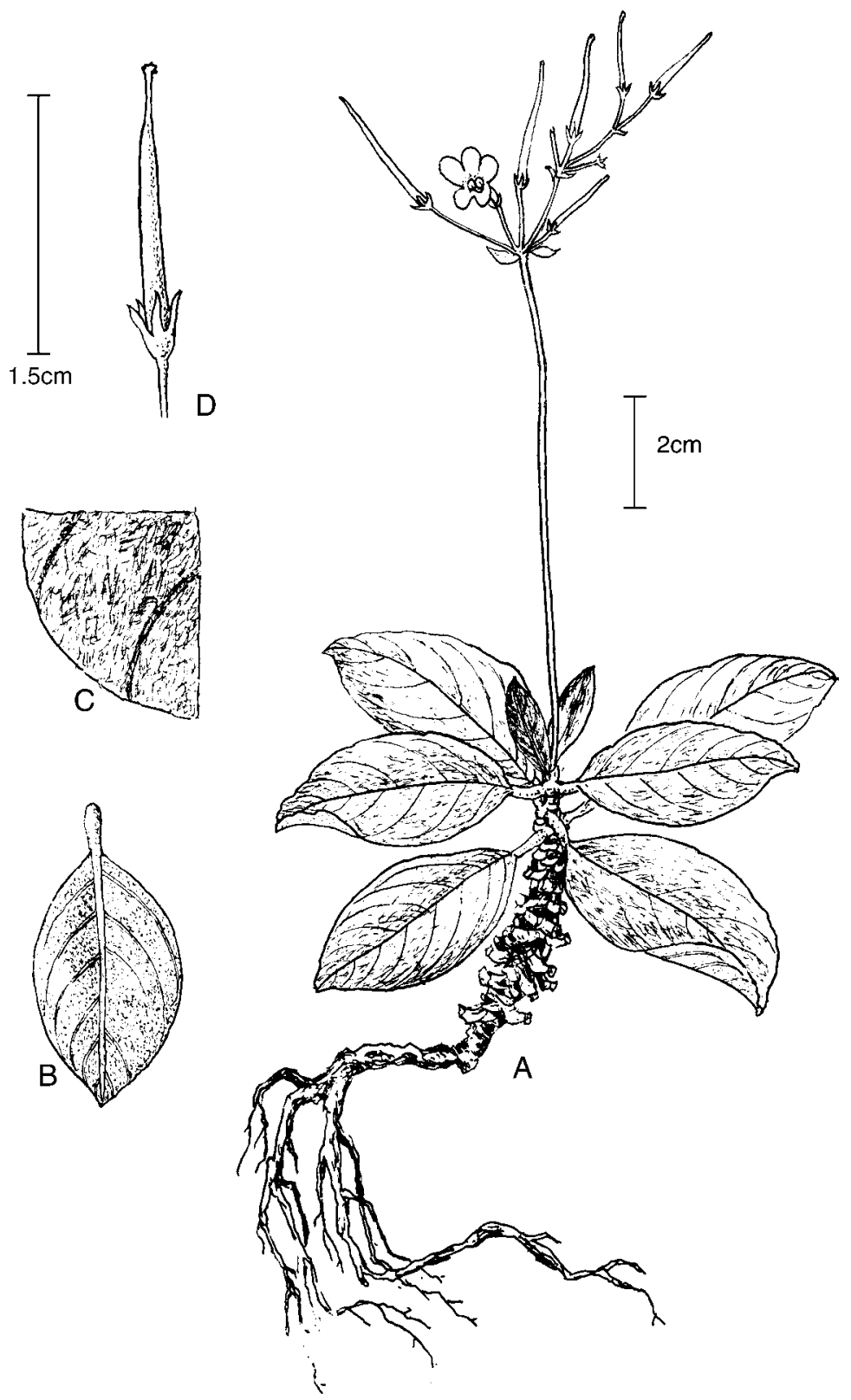

FIg. 40. Paraboea primuloides Z.R.Xu. A, habit; B, leaf; C, indumentum on leaf; D, pistil.

Burtt (1984) mis-cited Winkler 1150 as the type of Didymocarpus primuloides. This specimen typifies Didymocarpus johannis-winkleri Kraenzl. (1927). Burtt (1984) noted that Didymocarpus primuloides Kraenzl. is a later homonym of Didymocarpus primuloides (Miq.) Maxim. and he reduced the name to a synonym of Paraboea 
paraboeoides. However, in this study we have reduced Paraboea paraboeoides to a synonym of $P$. schefferi while we recognise Didymocarpus primuloides Kraenzl. as deserving specific status in Paraboea.

67. Paraboea prolixa (C.B.Clarke) B.L.Burtt, Notes Roy. Bot. Gard. Edinburgh 41: 435 (1984). - Boea prolixa C.B.Clarke in A.DC. \& C.DC., Monogr. Phan. 5: 143 (1883). - Type: Burma inferior, Thoungyun, Kurz s.n. (holo K).

Perennial caulescent herb, with a very short stem $7 \mathrm{~cm}$ long (partly rhizome?); internodes c. $5 \mathrm{~mm}$ long, with a brown matted indumentum. Leaves opposite; petiole 2-4 cm long; blades narrowly ovate, $9 \times 2.5-3.5 \mathrm{~cm}$, apex acute, base angustate, margin more or less serrulate, upper surface glabrous, lower surface with a brown matted indumentum; veins smooth above, invisible on the lower leaf surface. Inflorescence subterminal, cymose; infructescence c. $30 \mathrm{~cm}$ long, $6 \mathrm{~cm}$ wide; peduncle $20 \mathrm{~cm}$ long, with a brown matted indumentum; bracts 2, narrowly oblong, $7 \mathrm{~mm}$ long; pedicels c.5 mm long with some pubescence. Mature flower not seen, flower buds very tiny. Calyx persistent in the capsule, c. $2 \mathrm{~mm}$ long, 5-lobed to the base, lobes narrowly ovate, more or less hairy. Fruit a delicate capsule, c. $1-1.5 \mathrm{~cm}$ long, glabrous, spirally twisted. Mature seeds not seen.

Distribution. Burma. Known only from the type.

Habitat and ecology. Unknown.

Proposed IUCN conservation assessment. Data Deficient (DD). There is a taxonomic problem to be solved before a conservation assessment can be made (see note below).

The type is very poor. From the inflorescence structure and the delicate capsules it looks rather like Paraboea pubicorolla and P. patens. It is also possible that the species may be related to Paraboea cochinchinensis and P. harroviana. G. Den Hoed 580 (BKF, L, P), collected from near Wangka, has a similar indumentum in colour, but the leaves and the bracts are much larger. This specimen has been treated as Paraboea harroviana. Further collecting in the type locality of Paraboea prolixa may shed more light on its affinities.

68. Paraboea pubicorolla Z.R.Xu \& B.L.Burtt, Edinburgh J. Bot. 48 : 10 (1991). - Type: Thailand, Sisaket Province, Dongrak Range $\left(14^{\circ} 30^{\prime} \mathrm{N} 104^{\circ} 00^{\prime} \mathrm{E}\right)$ at Ching Bat Lak, Kantaralak District, $500 \mathrm{~m}$, on moist sandstone rocks by shaded stream zone, 17 viii 1976 (fl, fr), J.F. Maxwell 76-530 (holo L; iso AAU, BK).

Perennial caulescent herb, with a short stem or a rhizome $3-10 \mathrm{~cm}$ long, terete, c. $4 \mathrm{~mm}$ in diameter. Leaves oppositely congested, seemingly rosulate, petiolate; petiole $1-5.5 \mathrm{~cm}$ long, with narrow wings and joining across the nodes; blades ovate or elliptic, $4-13 \times 2.5-8.5 \mathrm{~cm}$, apex acute or obtuse, base shortly angustate, margin entire, upper surface arachnoid or glabrescent, lower surface with a greyish matted indumentum; veins smooth above, raised beneath, lateral veins c.10 pairs, tertiary 
venation obscure. Inflorescence subterminal, cymose, brown in colour when dry, glabrous except the pubescent corolla, often 2 opposite, sometimes 1 or 3 , axillary below the apical bud, much longer than the leaves, 25-35 cm long, 5-7 cm across, many-flowered; peduncle c. $22 \mathrm{~cm}$ long, with 2 or 3 bracts which are ovate or narrowly so, $5 \times 2-5 \mathrm{~mm}$; pedicel bracts similar in size to calyx lobes or slightly wider, pedicels c.5 mm long. Calyx 2-3 mm long, 5-lobed, lobes slightly obovate or oblong, c. $2 \times$ $0.5 \mathrm{~mm}$. Corolla purple or tube lilac and lobes blue, c. $10 \mathrm{~mm}$ long, $10 \mathrm{~mm}$ across, outside pubescent, inside glabrous; tube c. $7 \mathrm{~mm}$ long, limb 2-lipped; upper lip 2-lobed, lobes rounded, c. $4.5 \times 4.5 \mathrm{~mm}$, lower lip 3-lobed, two lateral lobes rounded, c. $3 \times$ $3.5 \mathrm{~mm}$, middle one obovate, $4 \times 3.5 \mathrm{~mm}$. Anthers transversely ellipsoid, c. $1 \times 3 \mathrm{~mm}$, coherent with each other, apex pointing towards the gynoecium, opening at the upper end, dorsifixed, somewhat pubescent; filaments c. $4 \mathrm{~mm}$ long, in the middle curved and twisted like an ' $\mathrm{S}$ ', forming a knee, upper part c.1 mm wide, lower part slender, c. $0.3 \mathrm{~mm}$ wide, minutely pubescent; 2 staminodes seen. Gynoecium c. $8 \mathrm{~mm}$ long; ovary c. $0.8 \mathrm{~mm}$ wide, smoothly passing into a style; stigma more or less oblique. Fruit a linear capsule, needle-like, $2.5-3 \mathrm{~cm}$ long, c.0.6-1 $\mathrm{mm}$ in diameter, glabrous, spirally twisted. Seeds compressed, ellipsoid or ovoid, c. $3 \times 1 \mathrm{~mm}$.

Distribution. Thailand (and Vietnam?).

Habitat and ecology. On sandstone substrate.

Proposed IUCN conservation assessment. Least Concern (LC). This species is both quite widespread and not confined to limestone and there are no major threats. This species was, however, included in Pooma (2005) as threatened in Thailand.

Additional specimens examined. Thailand. Sisaket: Khao Phra Viharn $\left[15^{\circ} 07^{\prime} \mathrm{N} 104^{\circ} 20^{\prime} \mathrm{E}\right]$, c.400 m, sandstone, 24 viii 1972 (fl, fr), T. Smitinand 11676 (BKF). Trat: Laem Nawp District, Chang Island (= Ko Chang) $\left[12^{\circ} 00^{\prime} \mathrm{N} 102^{\circ} 15^{\prime} \mathrm{E}\right], 100$ m, 2 viii 1973 (fl), J.F. Maxwell 73-310 (BKF).

VIETnAM. Binh Dinh: Qui Nhon, Col de Mangiang [134ㄴ $\left.{ }^{\prime} \mathrm{N} 109^{\circ} 14^{\prime} \mathrm{E}\right], 800 \mathrm{~m}, 19$ viii 1930 (fr, fl), E. Poilane 18024 (P). [Poilane 18024 may belong to this species, but the inflorescence is equal in length to the leaves and the pedicel has some glandular pubescence, different from the typical plants, which have inflorescence much longer than the leaves and pedicels glabrous. The specific description does not include this collection.]

This species has a similar inflorescence to Paraboea prolixa, $P$. cochinchinensis and $P$. harroviana. It can be distinguished from its possible relatives by its glabrous inflorescence and the pubescent corolla.

69. Paraboea rabilii Z.R.Xu \& B.L.Burtt, Edinburgh J. Bot. 48: 11 (1991). - Type: Thailand, Kaochom Lem, Ampoe Kaokao [07³5'N 9942'E], on rock, 1 viii 1929 (fl, fr), Rabil 301 (holo E; iso ABD, BKF, BM, K).

Boea lanata auct. non Ridl.: Barnett, Fl. Siam. Enum. 3(3): 231 (1962).

Paraboea lancifolia auct. non (Ridl.) B.L.Burtt: Burtt, Notes Roy. Bot. Gard. Edinburgh 41: 431 (1984), pro parte (quoad Rabil 301). 
Perennial subshrub; stem woody, c. $3.5 \mathrm{~mm}$ in diameter, bark peeling off with age. Leaves alternately congested at the apex of the stem, petiolate; petiole $0.5-3.5 \mathrm{~cm}$ long, with a matted indumentum; blades narrow-elliptic, $1.5-6 \times 0.5-1.5 \mathrm{~cm}, 3-5$ times as long as wide, apex acute or obtuse, base cuneate or angustate, margin entire and curving upward, upper surface with a minute pubescence, lower surface with a brown matted indumentum; veins smooth above, raised beneath, lateral veins 8-10 pairs, forming c $45^{\circ}$ angle with the midrib, tertiary venation obscure. Inflorescence axillary, cymose, c.1.5-5 cm long, 1-1.5 cm across, many-flowered, with a matted indumentum throughout except on the flowers; peduncle up to $2.5 \mathrm{~cm}$ long, peduncle bracts narrow-ovate, $3-8 \times 1.5-2 \mathrm{~mm}$; pedicel $2-5 \mathrm{~mm}$ long, pedicel bract sepal-like or a bit larger. Calyx 2-5 mm long, 5-lobed, lobes narrow-ovate, c. 4 times as long as wide, with a white matted indumentum outside, glabrous inside. Corolla white, glabrous, c. $5 \mathrm{~mm}$ long, $6 \mathrm{~mm}$ across; tube $2 \mathrm{~mm}$ long, limb 2-lipped; upper lip 2lobed, lobes wide-ovate, c. $2.5 \times 3.5 \mathrm{~mm}$, lower lip 3-lobed, two lateral lobes wideovate, $2 \times 3 \mathrm{~mm}$, middle one obovate, $2 \times 2.5 \mathrm{~mm}$. Anthers transversely ellipsoid, $1.5 \times 2 \mathrm{~mm}$, coherent with each other, opening in the centre of the anther locules, dorsifixed; filament c. $1 \mathrm{~mm}$ long. Gynoecium c. $5 \mathrm{~mm}$ long; ovary c. $1 \mathrm{~mm}$ across; style c. $0.25 \mathrm{~mm}$ across; stigma slightly larger than style, capitate. Fruit a narrow-oblong capsule, c. $1.5 \mathrm{~cm}$ long, $1.3 \mathrm{~mm}$ in diameter, glabrous, spirally twisted. Seeds elliptic or nearly so, $0.5 \times 0.2 \mathrm{~mm}$.

Distribution. Thailand. Known only from the type.

Habitat and ecology. Unknown.

Proposed IUCN conservation assessment. Critically Endangered (CR B1ab(ii,iii,v)) see conservation assessment section in introduction. This species was also included in Pooma (2005) as threatened in Thailand.

This species is similar to Paraboea suffruticosa but can be easily recognised by the large ratio of capsule vs. calyx (3-7 times) in a sharp contrast to $P$. suffruticosa (only 1.5-2 times).

70. Paraboea regularis (Ridl.) Ridl., J. Straits Branch Roy. Asiat. Soc. 44 : 67 (1905); Burtt, Notes Roy. Bot. Gard. Edinburgh 41: 435 (1984). - Didymocarpus regularis Ridl., J. Linn. Soc., Bot. 32: 515 (1896). - Type: Peninsular Malaysia, Langkawi [06 $\left.20^{\prime} \mathrm{N} 99^{\circ} 48^{\prime} \mathrm{E}\right], 1893$, C. Curtis (s.n.) cult. Hort. Bot. Sing. (lecto SING, designated by Burtt (1984: 435); iso E).

Perennial herb with a short stem, lacking any arachnoid covering. Leaves congested in a rosette; blades very unequal, oblong-lanceolate, $2-10 \times 1-6 \mathrm{~cm}$, c. $2-3$ times as long as wide, apex obtuse or rounded, base attenuate to widely cuneate, margin crenate (or crenulate), minutely pubescent above, with a matted indumentum or sparsely so beneath; veins slightly depressed above, raised beneath, lateral veins c.610 pairs, tertiary venation reticulate. Inflorescence axillary, cymose, similar in length 
to the leaf, c.4-8 $\mathrm{cm}$ long, with a matted indumentum throughout except for the flower; peduncle 3-6 cm long, with small sepal-like bracts; pedicels $2-5 \mathrm{~mm}$ long. Calyx c. $2 \mathrm{~mm}$ long. Corolla up to $0.5 \mathrm{~cm}$ wide, lobes oblong, apex obtuse. Stamens 2, filaments similar to the stigma, white; anthers round-ovoid, slightly compressed. Gynoecium white; ovary cylindric. Fruit c.1 cm long, non-twisted.

Distribution. Peninsular Malaysia (Langkawi) and Peninsular Thailand, with some doubtful collections from Cambodia and Vietnam.

Habitat and ecology. On limestone.

Proposed IUCN conservation assessment. Data Deficient (DD). See discussion below.

The type material was taken from a cultivated plant in the Singapore Botanic Garden. Ridley (1896) reported that the original material for this plant came from Langkawi (Island) and that the fresh flower had a snow white colour. The type is not a complete plant but consists of detached leaves and inflorescences, of which a drawing made by Rosemary Smith was preserved in E. From the available material this species may be related to Paraboea bakeri as both species have a similar habit and similar leaf and inflorescence morphologies. They differ in their capsule vs. calyx ratios (see discussion under Paraboea bakeri).

Pierre 4540 (P), which was previously named as Boea multiflora R.Br. var. burmannica C.B.Clarke (= Paraboea multiflora), has some similarity to this species in its general appearance and the non-twisted capsule. However, the yellowish sessile glands (or farinose indumentum) on the fruit suggests a close relationship to Paraboea multiflora R.Br. except that the latter species has twisted capsules. Also, Paraboea regularis is recorded from the area around Langkawi, an island off Peninsular Malaysia, but Pierre 4540 is recorded from southern Vietnam where P. multiflora occurs. Thus, more work is needed to clarify whether this collection is an abnormal specimen of Paraboea regularis or of $P$. multiflora, or if it belongs to neither species but is of an undescribed one.

Pierre 4540 is part of the original material of Boea multiflora var. burmannica C.B.Clarke. As Burtt (1984) has selected Parish 436 (K) as the lectotype for that name, removing Pierre 4540 from Boea multiflora var. burmannica does not result in a nomenclatural problem. Although we now reluctantly place the collection in Paraboea regularis, a description of the collection is included here:

Pierre 4540 (P): Rosulate herb. Leaves congested in a rosette; petiole 1-4 cm long, covered by a brunnescent matted indumentum; blades elliptic to obovate, $2-10 \times 1-$ $6 \mathrm{~cm}, \mathrm{c} .2-3$ times as long as wide, apex obtuse or rotundate, base attenuate to widely cuneate, margin crenate (or crenulate), minutely pubescent above, with a (sparse or dense) brunnescent matted indumentum beneath; veins slightly depressed above, raised beneath, lateral veins c.6-10 pairs, tertiary venation reticulate. Inflorescence axillary, cymose, similar in length to the leaf, c.4-8 cm long, many-flowered, with a matted indumentum except on the flower; peduncle $3-6 \mathrm{~cm}$ long, with small 
sepal-like bracts; pedicels 2-5 mm long. Flowers small, c. $4 \mathrm{~mm}$ long, $5 \mathrm{~mm}$ across when open. Calyx lobes c. $1.5 \mathrm{~mm}$ long, narrowly ovate, ferrugineously tomentose at least outside. Corolla glabrous, tube c. $3 \mathrm{~mm}$ long, limb slightly 2-lipped; all 5 lobes similar, oblong-ovate, c. $2 \times 1.2 \mathrm{~mm}$. Stamens 2 ; anthers oblong-ovate, $1 \times 1 \mathrm{~mm}$, opening near the apex, coherent at the apex, with very minute red sessile glands [or farinose].

Additional specimens examined. Thailand. 'Lower Siam', Palau Panji [possibly Ko Panji in Phangnga], 2 xii 1918 (fr), M. Haniff \& Nur 4013 (K, SING).

Doubtful collections: CAmBodia. 1866-1868 (fl, fr), M.L. Thorel 2268 (P).

Vietnam. Dong Nai: Mt. Dinh, near Baria (Phuoc Tuy, Long Khanh, Bien Hoa) $\left[10^{\circ} 32^{\prime} \mathrm{N}\right.$ $107^{\circ} 08^{\prime} \mathrm{E}$ ], ix 1867 (fr), H.L. Pierre 4540 (GH, K, NY, P, US).

71. Paraboea rufescens (Franch.) B.L.Burtt, Notes Roy. Bot. Gard. Edinburgh 38: 471 (1980); Burtt, Notes Roy. Bot. Gard. Edinburgh 41: 436 (1984), pro parte; Wang et al., Fl. Reipubl. Popularis Sin. 69: 465 (1990), pro parte. - Boea rufescens Franch., Bull. Mens. Soc. Linn. Paris 1 (no. 57): 449 (1885). - Dorcoceras rufescens (Franch.) Schltr., Bot. Jahrb. 58: 259 (1923). - Type: China, Kweichow [Guizhou], 1885 (fr, fl), M. Simon 1858 (lecto P, designated by Burtt (1984: 436)). Fig. 41.

Didymocarpus seguinii H.Lév. \& Vaniot, Compt. Rend. Assoc. Franc. Avancem. Sci. 34: 427 (1906). - Boea rufescens var. seguinii (H.Lév. \& Vaniot) H.Lév., Fl. KouyTchéou 181 (1914). - Type: China, Guizhou, Hoang Ko Chou [Huang2gu03shu4] [2559' N 105³5'E], 9 vi 1898 (fl), J. Seguin in Bodinier 2377 (lecto E, designated here; iso P).

Phylloboea henryi Duthie ex Beddome, J. Roy. Hort. Soc. 33: 96 (1908). - Type: China, Yunnan, Mengtze, Henry 9318 (lecto K, designated here; iso E, K, US).

Paraboea tribracteata D.Fang \& W.Y.Rao, Acta Phytotax. Sin. 33: 607 (1995).

- Type: China, Guizhou, Libo, on limestone, W. Y. Rao 79047 (holo GXMI).

\section{1a. Paraboea rufescens var. rufescens}

Perennial rosulate herb with or without a short rhizome up to $12 \mathrm{~cm}$ long. Leaves oppositely congested in a rosette, petiolate; petiole $1-10 \mathrm{~cm}$ long with the same indumentum as that on the leaves; blades ovate, elliptic, $3-10 \times 1.5-5 \mathrm{~cm}, 1.5-$ 3 times as long as wide, apex obtuse, base cuneate to truncate, margin serrate or indistinctly so, upper surface densely pubescent, lower surface with a yellowish to dark brown or ferrugineous matted indumentum; veins obscure above, raised beneath, lateral veins c.6 pairs, tertiary venation reticulate or indistinctly so. Inflorescence axillary, cymose, normally longer than the leaves, primary and secondary branches of the cyme hardly developed and so appearing umbellate (or in bud capitate), many-flowered, with a matted indumentum on peduncles, bracts, pedicels and calyx when young, more or less shedding off when older; peduncle 4-12 cm long with two large ovate bracts enclosing the flower buds when young, up 


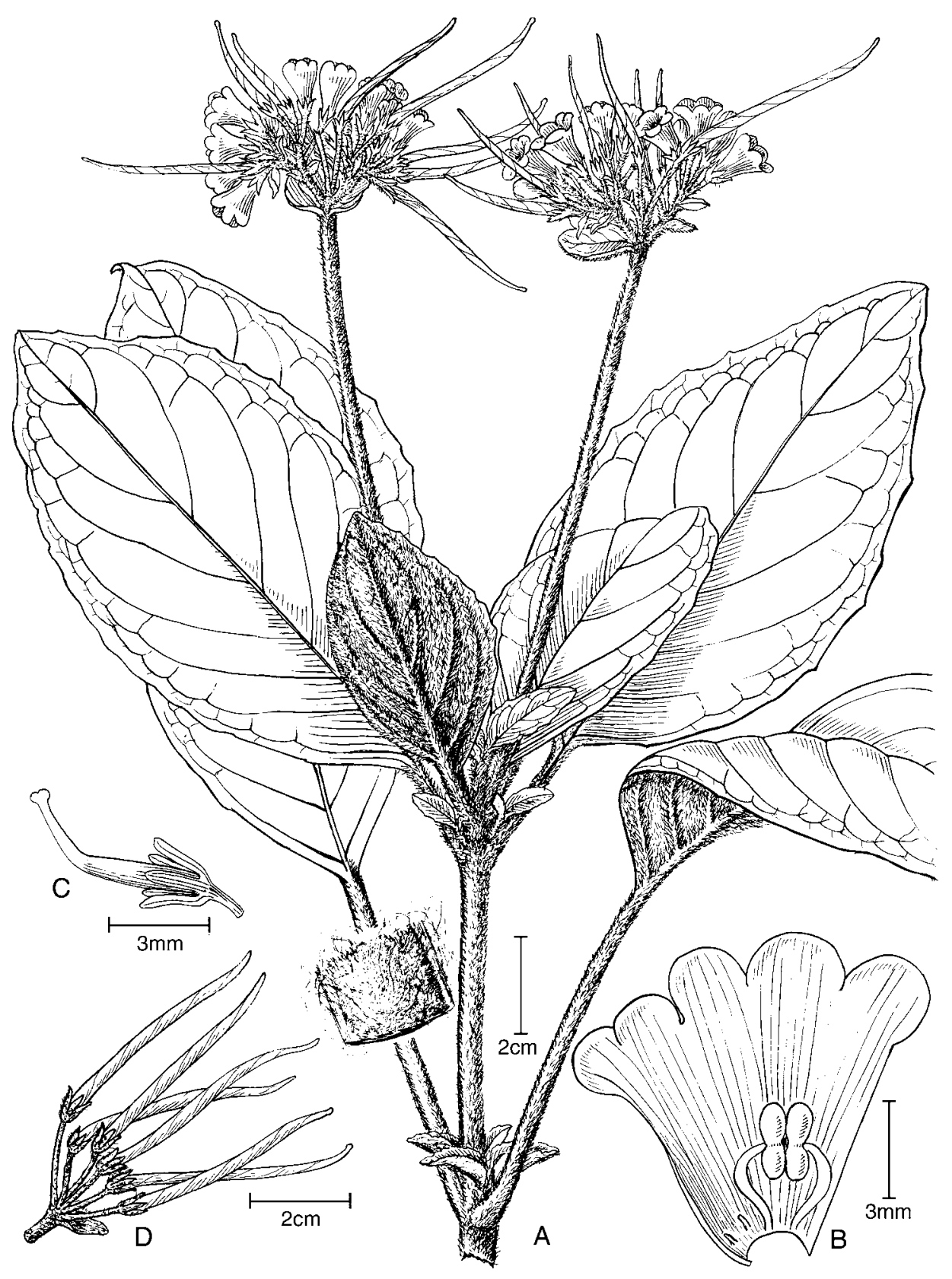

Fig. 41. Paraboea rufescens (Franch.) B.L.Burtt. A, habit; B, corolla opened out; C, pistil; $\mathrm{D}$, fruits. 
to $12 \times 6 \mathrm{~mm}$; pedicels c.5-10 $\mathrm{mm}$ long, bracts indistinct. Calyx c. $3 \mathrm{~mm}$ long, 5lobed to the base, lobes narrowly oblong, c. $2.5 \times 0.6 \mathrm{~mm}$, apex truncate or slightly sinuolate, spreading outward. Corolla violet or blue, glabrous, c. $10 \mathrm{~mm}$ long, $8 \mathrm{~mm}$ across; tube c.6 mm long, limb not remarkably 2-lipped; upper lip 2-lobed, lobes widely ovate, c. $3 \times 5 \mathrm{~mm}$, lower lip 3-lobed, lateral lobes rounded, c. $3 \times 4 \mathrm{~mm}$, middle lobe similar in shape, c. $4 \times 4.5 \mathrm{~mm}$. Anthers transversely ellipsoid, c. $2 \times$ $4 \mathrm{~mm}$, coherent with each other, apertured at the upper end, apex turned towards the gynoecium, basifixed; filaments inserted at the extreme base of the corolla with a free part c.3.5 mm long, pubescent; staminodes 2, one of which c. $1 \mathrm{~mm}$ long, the other almost invisible. Gynoecium c.10 $\mathrm{mm}$ long, $1.2 \mathrm{~mm}$ wide at the base of the ovary; stigma oblique, seemingly scabrous. Fruit a linear capsule, $3-4.5 \mathrm{~cm}$ long, $1.5 \mathrm{~mm}$ in diameter, glabrous, spirally twisted. Seeds ellipsoid, c. $0.5 \times 0.22 \mathrm{~mm}$.

Distribution. South and southwest China (possibly also in northern Vietnam).

Habitat and ecology. On limestone. The species is remarkable in its habitat preference as it is often found on exposed and unshaded barren limestone rocks without any visible soil layer and any other associated plants.

Proposed IUCN conservation assessment. Least Concern (LC). This variety has been collected at many sites over a wide area and there are no major threats.

Additional specimens examined. CHINA. (fl, fr), J. Esquirol 896 (E). Guangdong: 6 vi 1907 (fl), K. K. Chung 1827 (IBSC); K.K. Tsoong 3725 (A). Guangxi: Tian E Xian [Tian1e2 Co.], Shangli

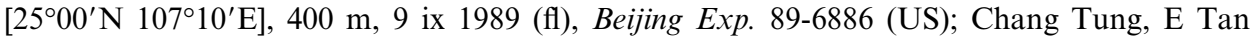
Shan, on open cliff, herb uniserial to $8^{\prime}$, deep green above, tawny brown beneath, $933 \mathrm{~m}, 27 \mathrm{vii}$ 1928 (fl, fr), R.C. Ching 6567 (A, NY, W); (fr), S.K. Lau 28450 (E); C. Wang 41291 (A);

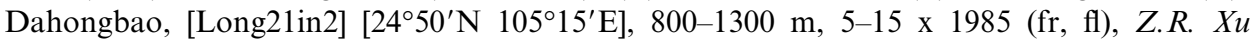

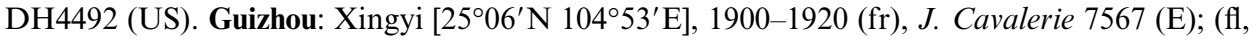

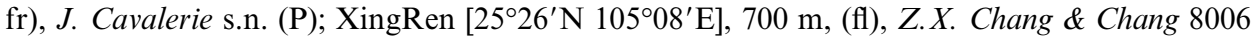

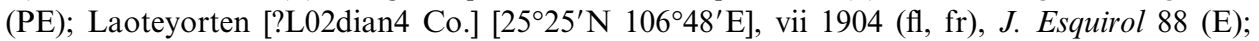

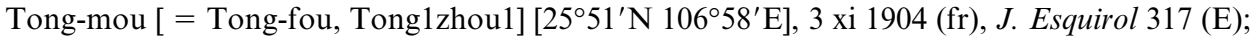
Tchong-fou [Chang2shun4] [26 $02^{\prime} \mathrm{N} \mathrm{106}{ }^{\circ} \mathrm{E}$ ], 28 vi 1905 (fr), J. Esquirol s.n. (E); Zhengfeng

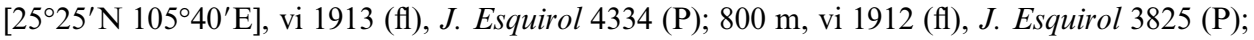
vii 1911 (fr, fl), J. Esquirol 3086 (P); Chu-Hsiung, Tuan-Shan [Du2shan1, Guizhou] [2550' N $107^{\circ} 32^{\prime}$ E], 1100 m, 17 ix 1939 (fr), M.K. Li 29 (PE); 27 vii year? (fr, fl), J. Seguin in Bodinier

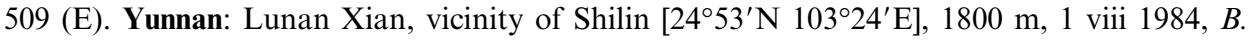
Bartholomew et al. (SINO-US) 1566 (A); (fl, fr), F. Ducloux 336 (NY); 23 vii 1905 (fr, fl), F. Ducloux 3712 (P); 1533 m, (fl, fr), A. Henry 9318 (E, MO); Yuan-Ching, (fr, fl), A. Henry 13385 (NY, US); Dan-mu, 12 x 1979 (fr), J. Muraba \& Yamazaki 9262 (P); Bei Yangtze Faenre Laka tiang Felsenschlucht, 19 iii 1914 (fr), C. Schneider 483 (K); zw. Yüenkiang \& Damingan, 460-1160 m, 1934, H. von Wissmann 812 (W); Yangtse-kiang, between Yunnanfu \& Huili, 900-2000 m, 18 iii 1914, Handel-Mazzetti 714 (W).

Vietnam. Ha Noi: [2102' N 10550'E], 3 vii 1917 (fl, fr), J. Esquirol 6153 (P) - doubtful collection; see note below.

Paraboea rufescens possesses a distinctive thick layer of yellowish to dark brown or ferrugineous matted indumentum on the lower leaf surface. It is possibly related to Paraboea umbellata from which it can be distinguished by the smaller leaves and the 
true axillary cymes from basal leaves (vs. subterminal cymes from an extended flowering stem). The capsules are generally around $4 \mathrm{~cm}$ long, but one specimen from China (Yunnan), C. Schneider 483 (K), has much shorter capsules (c.1.5 cm long).

The Esquirol collection from Vietnam is more than likely mislabelled because Esquirol is not known to have made collections in Vietnam. Pellegrin (1930) identified two specimens from Vietnam as Boea rufescens Franch. (= Paraboea rufescens). One of those two collections, Bon 2688A (P), in fruit, from 'Tonkin Occidental', has been identified as Paraboea umbellata in this study. The other collection, which was collected from Annam (south Vietnam) by Poilane, has not been found by us but is unlikely to be Paraboea rufescens given its locality. The distribution of Paraboea umbellata is along the South China Sea coast, and $P$. rufescens from central China westward to Yunnan, Burma and Thailand. If Paraboea umbellata is eventually found in Vietnam it is likely to be on the border with Yunnan in Lai Chau or Lao Cai.

Fang and Rao described a typical plant of Paraboea rufescens when they published $P$. tribracteata. They distinguished their new species by its ' 3 bracts'; however, 2-4 bracts, generally large and obvious in size, are common in Paraboea rufescens.

71b. Paraboea rufescens var. tomentosa (Barnett) Z.R.Xu, stat. nov. - Paraboea tomentosa Barnett, Dansk Bot. Ark. 20: 202 (1962). - Type: Thailand, Northern region, Chiengmai [Chiang Mai], Doi Chieng Dao, Larsen 4078 (holo C; iso ABD).

This variety differs from Paraboea rufescens var. rufescens in the dark brown colour of the indumentum on the lower leaf surface and the extended primary branches of the cyme. In Paraboea rufescens var. rufescens the primary and the secondary branches of the cyme are short or hardly develop making the cyme appear umbellate, even in the infructescence. In Paraboea rufescens var. tomentosa the primary branches of the cyme in the infructescence always extend to c.3-4 cm long and the secondary branches to $\mathrm{c} .1 \mathrm{~cm}$ long. This gives the cyme a truly dichasial appearance. The two varieties do not overlap geographically; Paraboea rufescens var. rufescens is found only in China (and northern Vietnam?) and P. rufescens var. tomentosa is in Thailand and Burma. There are some other differences between the two varieties. The flowers of the Chinese collections (i.e. Paraboea rufescens var. rufescens) are usually blue or violet in colour, and the Thai collections (i.e. P. rufescens var. tomentosa) are recorded as pinkish and reddish in colour. Colour, however, may not be reliable in delimiting a species. They also differ in bract morphology. The Chinese plants have two large bracts $(\mathrm{c} .12 \times 6 \mathrm{~mm})$ on top of the peduncle and these envelop the flower buds of the young inflorescence. The bracts in the Thai plants measure only $6 \times 2 \mathrm{~mm}$ and do not envelop the young flowers in the juvenile inflorescence. Burtt (1984) and Wang et al. (1990) both reduced Paraboea tomentosa Barnett to a synonym of Paraboea rufescens (Franch.) B.L.Burtt. As the differences in the inflorescences and the peduncle bracts between the two groups of plants mentioned can be used to recognise two quite clear entities, but these entities are not sufficiently 
distinct to warrant specific limitation, we recognise Barnett's species here as a variety of Paraboea rufescens.

Distribution. Burma and Thailand.

Habitat and ecology. On limestone.

Proposed IUCN conservation assessment. Least Concern (LC). This variety has been collected at many sites over a wide area and there are no major threats.

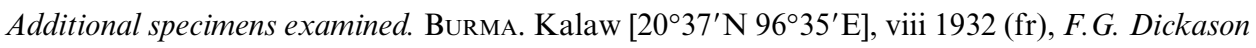
1093 (GH).

Thailand. Chiangmai: Fang [19²0'N 98 50'E], 2 vii 1978 (fl, fr), C. Phengklai et al. 4222 (BKF); between Chiang Dao and Fang, 500 m, 7 vi 1973 (fr, fl), R. Geesink et al. 5762 (E, L);

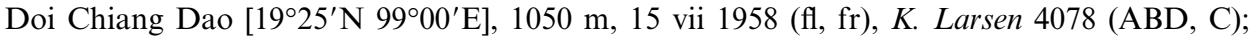
ibid., 600-1300 m, 25 ix 1971 (fr), G. Murata et al. 14995 (L); ibid., 18 x 1926 (fr), Put 389 (K); ibid., 1100 m, 15 vii 1958 (fl, fr), T. Smitinand 4689 (BKF); ibid., 1100-1800 m, 16 viii 1963 (fr, fl), T. Smitinand et al. 1036 (BKF, E, L); ibid., 1100 m, 16 ii 1958 (fr), T. Sorensen et al. 1233 (C); ibid., 1050 m, 15 vii 1958 (fl, fr), Sorensen et al. 4077 (ABD, BKF, C); ibid., 1050 m, v 1963 (fl, fr), Sorensen et al. 4078 (photos NY, UC).

72. Paraboea sabahensis Z.R.Xu \& B.L.Burtt, Edinburgh J. Bot. 48: 12 (1991). - Type: Malaysia, Sabah, Lamag District, near Bilit, Sopiloring hill, Kinabatangan, in limestone primary forest, $350 \mathrm{ft}$ (c.100 m), 18 iv 1963 (fl, fr), J. Ampuria SAN35269 (holo E; iso K, L, SAN, SAR). Fig. 42.

Perennial caulescent subshrub; stem woody, c. $1 \mathrm{~cm}$ in diameter, internodes $1-3 \mathrm{~cm}$ long, with a white matted indumentum when young and later glabrescent. Leaves in whorls of 3, leaf base long-attenuate into a short petiole $0.5-1.5 \mathrm{~cm}$ long; blades narrow-elliptic and more or less obovate, $6.5-13 \times 1.5-3 \mathrm{~cm}, 3-5$ times as long as wide, apex obtuse, base long-attenuate into a short petiole, margin entire, upper surface with a dense pubescence of an arachnoid layer which sheds off with age, lower surface with a white matted indumentum; veins obscure above, more or less visible beneath, lateral veins c.8 pairs. Inflorescence terminal, paniculate, with a white matted indumentum throughout except on the flowers; flowering stems $10-30 \mathrm{~cm}$ long, the most basal internodes c.3-9 cm long, floral leaves intermediate in size to vegetative leaves, 3 cymes from each node; basal cymes c. $10 \mathrm{~cm}$ long, many-flowered, peduncle bract c. $5 \times 3 \mathrm{~mm}$, pedicel bracts sepal-like; pedicel c.0.5-1 cm long. Calyx 2-3 mm long, 5-lobed, lobes narrow-ovate, c.4 times as long as wide, with a white matted indumentum outside. Corolla purple, glabrous, c. $6.5 \mathrm{~mm}$ long, $8 \mathrm{~mm}$ across; tube c. $2 \mathrm{~mm}$ long, limb 2-lipped; upper lip 2-lobed, lobes wide-ovate, c. $3 \times 3.5 \mathrm{~mm}$, lower lip 3-lobed, two lateral lobes wide-ovate, $4 \times 5 \mathrm{~mm}$, middle one obovate, $3 \times$ $3.5 \mathrm{~mm}$. Anthers transversely ellipsoid, $2 \times 3.5 \mathrm{~mm}$, coherent with each other at the apex and the base, opening in the centre of the anther locules, apex turned towards the gynoecium, dorsifixed; filaments slightly curved, c. $2.5 \mathrm{~mm}$ long, $0.7 \mathrm{~mm}$ wide. Gynoecium c. $4.5 \mathrm{~mm}$ long; ovary c. $1 \mathrm{~mm}$ in diameter; stigma capitate, not enlarged. 


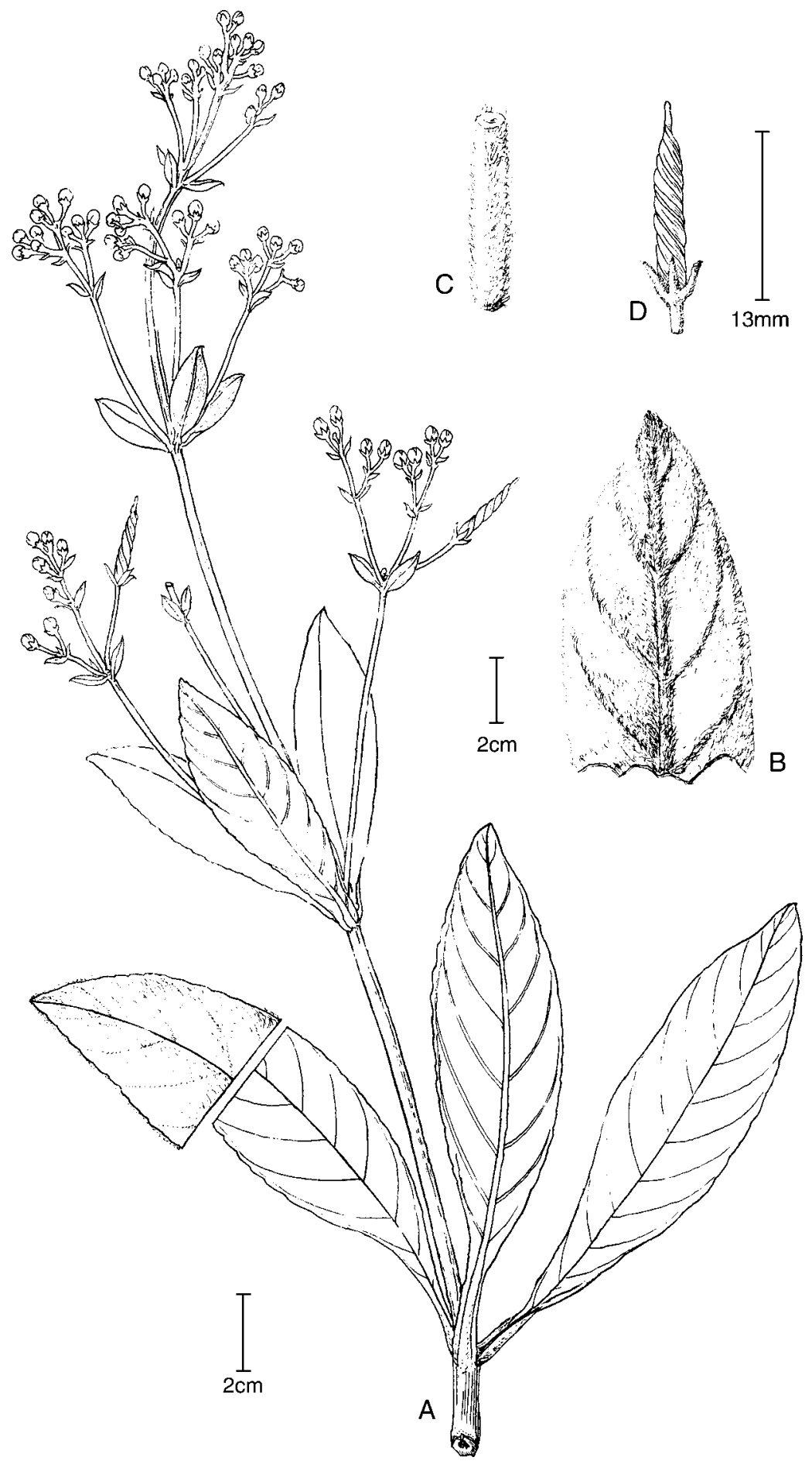

Fig. 42. Paraboea sabahensis Z.R.Xu \& B.L.Burtt. A, habit; B, leaf; C, section of peduncle; $\mathrm{D}$, fruit. 
Fruit a narrow ovoid capsule, $1-1.7 \mathrm{~cm}$ long, $1.5-2.5 \mathrm{~mm}$ in diameter, glabrous, spirally twisted. Seeds ovoid, $0.5 \times 0.2 \mathrm{~mm}$.

Distribution. Malaysia: Sabah.

Habitat and ecology. On limestone.

Proposed IUCN conservation assessment. Endangered (EN B1ab(ii,iii,v)). This species is only known from two localities. Although the extent of occurrence is possibly $<100 \mathrm{~km}^{2}$, which would justify a Critically Endangered category, the two localities reduces the threat somewhat and Endangered is a more suitable category.

Additional specimen examined. Malaysia. Sabah: Sapulut District, Batu Punggul, 405 m, 28 i 1993 (fl), Fidilis \& J. Sumbing SAN135773 (E).

This species is similar to Paraboea candidissima in its thick matted indumentum, but differs in its smaller and narrower obovate leaves. J. Ampuria noted that the flower is yellow. This likely refers to the conspicuous yellow anthers but not to the corolla as there is no other record of a yellow corolla in this genus.

73. Paraboea scabriflora B.L.Burtt, Notes Roy. Bot. Gard. Edinburgh 41: 437 (1984).

- Type: Sumatra, Atjeh [Aceh], Gunung Leuser Nature Reserve, Gunung Ketambe and vicinity, 8-15 km SW from the mouth of Lau Ketambe, c.40 km NW of Kutajane, 1800-1900 m, Camp 5, on steep limestone rock in montane rainforest, 16 viii 1972, W.J.J.O. de Wilde \& B.E.E. de Wilde-Duyfjes 14332 (holo $\mathrm{L}$; photo E).

Perennial herb with a short stem c. $10 \mathrm{~cm}$ long when in flower, rhizome c. $10 \mathrm{~cm}$ long; internodes c. $1 \mathrm{~cm}$ long and extending up to $5 \mathrm{~cm}$ long when in flower; indumentum the same as that on the lower leaf surface. Leaves opposite, congested on the lower part of the stem but less so on the upper part, petiolate; petiole 4-8 cm long, slightly swelling at the base and joining across the node, indumentum the same as that on the lower leaf surface; blades elliptic or ovate, 7-14 $\times 3.5-6.5 \mathrm{~cm}, 1.5-2.5$ times as long as wide, apex acute to obtuse, base unequal and more or less shortly angustate, margin crenate-serrate, upper surface pubescent, lower surface with long unbranched multicellular hairs mixed with a layer of a fine interwoven matted indumentum; veins smooth above, raised beneath, lateral veins 6-8 pairs, tertiary venation reticulate. Inflorescence subterminal, cymose; often two cymose flowering branches opposite in the uppermost axils below the apical bud, up to $5.5 \mathrm{~cm}$ long, with leaflet-like bracts at the apex of the cymose peduncle; leaflet-like bracts $\mathrm{c} .1 \mathrm{~cm}$ long with a $\mathrm{c} .0 .5 \mathrm{~cm}$ long petiole; the whole cymose flowering branch up to $10 \mathrm{~cm}$ long, $5 \mathrm{~cm}$ wide, manyflowered; two primary branches dichasially developing from the cymose peduncle, up to $7 \mathrm{~cm}$ long, with the same indumentum as that on the lower leaf surface, with 2 linear bracts c. $6 \times 1 \mathrm{~mm}$ growing not at the apex of this primary branch but c. $5 \mathrm{~mm}$ lower; pedicels 5-10 mm long, pubescent. Calyx c.2.5 mm long, 5-lobed to the base, 
lobes narrowly ovate, c. $1 \mathrm{~mm}$ wide, pubescent outside, glabrous inside. Corolla campanulate, c. $9 \mathrm{~mm}$ long, $7 \mathrm{~mm}$ across; tube c. $7 \mathrm{~mm}$ long, limb indistinctly 2lipped; 5 lobes of similar size and shape, wide-ovate, c. $1.5 \times 2.5 \mathrm{~mm}$. Anthers transversely ellipsoid, c. $1.5 \times 3.5 \mathrm{~mm}$, seemingly coherent with the gynoecium but not adnate to each other, open at the upper end, apex turned towards the gynoecium, dorsifixed; filaments inserted at c. $0.5 \mathrm{~mm}$ from the corolla base with a free part c. $2 \mathrm{~mm}$ long; staminodes 3, two of $1.5 \mathrm{~mm}$ long and one of $0.5 \mathrm{~mm}$ long. Gynoecium c. $7 \mathrm{~mm}$ long; ovary ovoid, c. $3 \times 1 \mathrm{~mm}$; style distinct from the ovary, c. $4 \mathrm{~mm}$ long; stigma slightly larger than style. Young fruit a linear capsule, c. $2 \mathrm{~cm}$ long, glabrous, visibly twisted. Seeds not seen.

Distribution. Indonesia: Sumatra. Known only from the type.

Habitat and ecology. On limestone.

Proposed IUCN conservation assessment. Critically Endangered (CR B1ab(ii,iii,v)) see conservation assessment section in introduction.

This species is likely closely related to Paraboea glanduliflora. They are similar in their subterminal cymose inflorescence. However, they are very different in their indumentum for Paraboea glanduliflora has a glandular pubescence on the inflorescence and P. scabriflora has a mixture of a long unbranched pubescence and a matted indumentum. Our study does not support the suggested relationship between this species and Paraboea detergibilis (Burtt, 1984). The two species differ in indumentum, inflorescence structure and capsule morphology.

74. Paraboea schefferi (H.O.Forbes) B.L.Burtt, Kew Bull. 1948: 56 (1948); Burtt, Notes Roy. Bot. Gard. Edinburgh 41: 438 (1984). - Didymocarpus schefferi H.O.Forbes, J. Linn. Soc., Bot. 19: 298 (1882). - Type: Borneo, Pulau Pandan, Teysmann 8430 (lecto BM, designated by Burtt (1984: 438); photo K). Fig. 43. Didymocarpus paraboeoides Kraenzl., Mitt. Inst. Bot. Hamburg 7: 90 (1927). - Paraboea paraboeoides (Kraenzl.) B.L.Burtt, Notes Roy. Bot. Gard. Edinburgh 41: 434 (1984). - Type: [Indonesia, Kalimantan], West Borneo, Bukit Pehipit, 9 xii 1924, Winkler 672 (holo HBG).

Boea borneensis Scheff. ex H.O.Forbes, J. Linn. Soc. 19: 298 (1882), nom. illeg. (in synonymy).

\section{4a. Paraboea schefferi var. schefferi}

Perennial herb with a woody stem; stem normally $15-40 \mathrm{~cm}$ long, up to $1 \mathrm{~cm}$ in diameter, with a thick layer of matted indumentum, which is so appressed and so smooth on the surface that it would be easily mistaken as a glabrous bark on the stem, the bark of the stem under this layer of indumentum is very loose, internodes 5-30 mm long. Leaves opposite, cauline, petiolate; petiole c. $2-10 \mathrm{~cm}$ long, enlarged at the base and joining each other across the node, with a whitish matted 


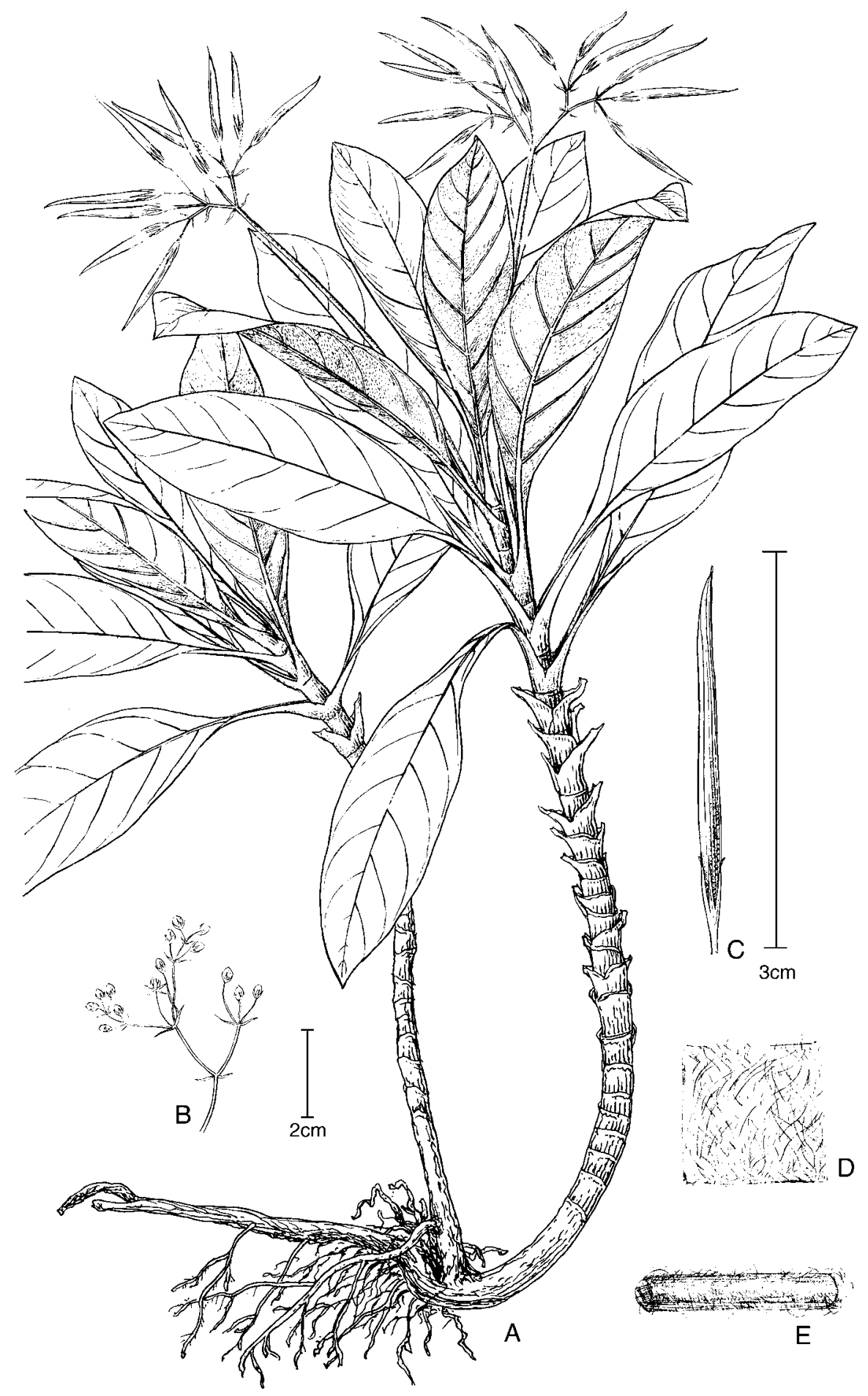

FIG. 43. Paraboea schefferi (H.O.Forbes) B.L.Burtt. A, habit; B, part of inflorescence; C, fruit; D, indumentum on leaf; E, section of peduncle. 
indumentum; blades oblong-elliptic or elliptic, c.10-15 × 3.5-6.5 cm, c.1-2 times as long as wide, apex obtuse or acute, base cuneate or widely so, margin entire, upper surface arachnoid when young and glabrescent when mature, lower surface with a whitish matted indumentum; veins smooth above, raised beneath, lateral veins c.710 pairs, tertiary venation obscure. Inflorescence an axillary cyme, much longer than the leaf, c. $20-40 \times 10-15 \mathrm{~cm}$, with c. 4 bifurcations, bearing several to many flowers; peduncle \pm with some matted indumentum, $20-30 \mathrm{~cm}$ long, two primary bracts narrowly ovate, c.3-5 mm long, with minute sessile glands on the upper surface; pedicels $5 \mathrm{~mm}$ long, glabrous, with sepal-like secondary bracts similar in morphology to the primary bracts. Calyx lobes narrowly ovate, c. $2.5 \times 0.8 \mathrm{~mm}$, glabrous outside, minutely pubescent inside. Corolla blue, blue-pink, purple-violet or violet, c. $5 \mathrm{~mm}$ across, minutely pubescent outside and inside; tube 1.5-2 mm long, limb 2-lipped; upper lip 2-lobed, lobes rounded, c. $3 \times 3 \mathrm{~mm}$, lower lip 3-lobed, lobes c. $4 \times 4 \mathrm{~mm}$. Anthers \pm triangular, $2.2 \times 3.2 \mathrm{~mm}$, opening in the centre of the anther locules, coherent, \pm dorsifixed; filaments $1.5 \mathrm{~mm}$ long. Gynoecium $3.5 \mathrm{~mm}$ long, ovary $1 \mathrm{~mm}$ wide; style $0.4 \mathrm{~mm}$ wide; stigma slightly larger than style. Fruit a linear non-twisted capsule up to $4 \mathrm{~cm}$ long, very slender, \pm curved. Seeds compressed, ovoid.

Distribution. Borneo.

Habitat and ecology. Reported from limestone.

Proposed IUCN conservation assessment. Endangered (EN B1ab(ii,iii,v)). This variety is only known from a few localities. We are unsure of the extent of occurrence but do not believe it to be above $5000 \mathrm{~km}^{2}$.

Additional specimens examined. Indonesia. West Kalimantan: Pulow [Pulau] Sepandan, D. Luar, 10 viii 1949 (fl, fr), Main exp. E. Polak, F.H. Endert 1991 (K, L); exp. Liang-gagang, 1893 (lv), H. Hallier 94 (L).

No specific differences can be found between Paraboea schefferi and the type of Didymocarpus paraboeoides except that the internodes are somewhat longer in the latter. Thus, we reduce Didymocarpus paraboeoides to synonymy. Paraboea schefferi belongs in a group of species with $P$. luzoniensis, $P$. minahassae and $P$. leopoldii. Within this group it is most distinctive by a combination of cuneate leaf blade base, a large inflorescence and distinct internodes.

74b. Paraboea schefferi var. ambigua (C.B.Clarke) Z.R.Xu, comb. nov. - Didymocarpus schefferi H.O.Forbes var. ambigua C.B.Clarke in A.DC. \& C.DC., Monogr. Phan. 5: 106 (1883). - Type: prope Karimata, Teysmann 4214 (BM, not found). Neotype: Borneo, Karimata Arch., Poelau Pelapis Tiangbalai, 21 iii 1931 (fr), Mondi 129 (neo L, designated here; isoneo K, SING).

This variety differs from Paraboea schefferi var. schefferi in its cordate or rounded leaf base. Also, the two varieties are isolated geographically: Karimata Archipelago is a group of small islands off the south coast of Borneo. 
Distribution. Borneo: Karimata Archipelago.

Habitat and ecology. Unknown.

Proposed IUCN conservation assessment. Endangered (EN Blab(ii,iii,v)). This variety is only known from two localities. The collection localities are from the same group of islands but within those it is not clear how far apart the collections were made. We are confident, however, that the extent of occurrence is not more than $5000 \mathrm{~km}^{2}$, justifying the EN category.

The type has not been found, but Mondi 129 (K, L, SING), collected from the type locality, matches the description by Clarke (1883) well and is selected here as a neotype.

75. Paraboea sinensis (Oliv.) B.L.Burtt, Notes Roy. Bot. Gard. Edinburgh 38: 471 (1980); Burtt, Notes Roy. Bot. Gard. Edinburgh 41: 438 (1984); Wang et al., Fl. Reipubl. Popularis Sin. 69: 464 (1990). - Phylloboea sinensis Oliv., Hook. Ic. P1. 18: t.1721 (1887). - Chlamydoboea sinensis (Oliv.) Stapf, Bull. Misc. Inform. Kew 1913: 355 (1913). - Type: China, Hupeh (Hubei), Ichang, Henry 1572 (holo K). Fig. 44.

Chlamydoboea sinensis (Oliv.) Stapf forma macrophylla Stapf, Bull. Misc. Inform. Kew 1913: 355 (1913). - Type: China, Yunnan, Szemao [Simao] [22 $\left.50^{\prime} \mathrm{N} 101^{\circ} 02^{\prime} \mathrm{E}\right]$ (fl), $4500 \mathrm{ft}$ (c.1350 m), Henry 12305 (lecto K, designated here).

Chlamydoboea sinensis (Oliv.) Stapf forma macra Stapf, Bull. Misc. Inform. Kew 1913: 355 (1913). - Type: China, Yunnan, South of Red River, (fr), A. Henry 9630 (lecto $\mathrm{K}$, designated here; iso US).

Boea macrophylla Drake, Bull. Soc. Philom. Paris, sér. 8, 2: 130 (1890); Pellegrin in Lecomte, Fl. Indo-Chine 4: 544 (1930). - Type: Tonkin, forêts de Mont Bavi, Balansa 4304 (lecto P, designated by Burtt (1984: 438)).

Boea chaffanjonii H.Lév., Repert. Spec. Nov. Regni Veg. 9: 330 (1911). - Type: China, Kweichow, env. de Houy-yang, Chaffanjon in herb. Bodinier 2312 (holo E).

Perennial caulescent herb; stem woody, up to $1 \mathrm{~m}$ long, $5 \mathrm{~mm}$ in diameter, with internodes c. $1 \mathrm{~cm}$ long, with a brown matted indumentum when young, glabrescent when older. Leaves opposite, petiolate; petiole $2-10 \mathrm{~cm}$ long, indistinctly joining across the node, with the same indumentum as that on the lower leaf surface; blades elliptic, or narrowly so, 7-26 × 2-10 cm, 2-3 times as long as wide, apex obtuse or acute, base cuneate, margin entire or serrulate, upper surface with some arachnoid covering and later glabrescent, lower surface with a brown or greyish matted indumentum; veins obscure above, raised beneath, lateral veins 10-15 pairs. Inflorescences subterminal, cymose; cymes often two opposite to each other from the uppermost axils, the two floral leaves much smaller than the mature vegetative 


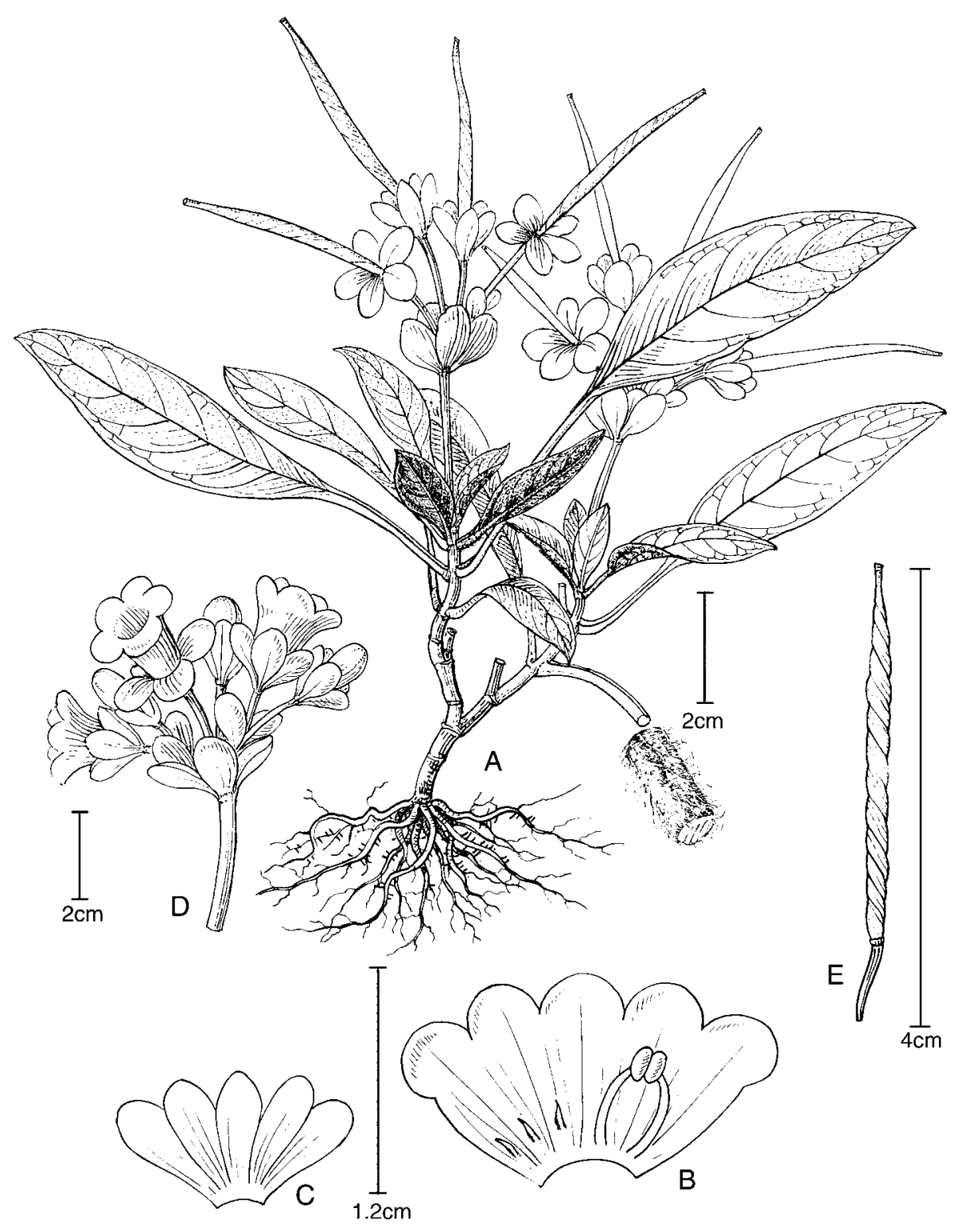

FIg. 44. Paraboea sinensis (Oliv.) B.L.Burtt. A, habit; B, corolla opened out; C, calyx opened out; D, inflorescence; E, fruit.

leaves, sometimes joining each other to form a seemingly large leaflet-like bract, making the young inflorescence appear terminal; juvenile cymes having many congested flowers embraced by numerous large membranous bracts, appearing like a capitulum, and then gradually extending into a tight cyme c.5-10 cm long, $3-6 \mathrm{~cm}$ 
wide; peduncle 2-4 cm long, with a matted indumentum, bracts large, wide-ovate or rounded, 1-1.5 cm long, membranous, glabrous (reddish or white but with blue and pinkish in the upper part); pedicels 5-10 mm long with bracts of similar shape to the peduncle bracts but smaller. Calyx white or reddish, large, lobes narrowly trapeziform but more or less rounded at the apex, or \pm narrowly obovate, c.10-15 mm long, 5-7 mm wide. Corolla violet, violet-blue, blue, lilac, purple-red, purple or white with blue and purple, c. $15 \mathrm{~mm}$ long, $13 \mathrm{~mm}$ across when fully open; tube c. $10 \mathrm{~mm}$ long, swelling at the base and where the stamens are inserted, limb not distinctly 2lipped; lower lip slightly larger than the upper lip, with 5 lobes of similar size and shape, widely ovate, c. $4 \times 5 \mathrm{~mm}$. Anthers reniform, c. $2.5 \times 4 \mathrm{~mm}$, coherent with each other at the apex, opening towards the top of the anther, apex truncate or turning towards the gynoecium, dorsifixed; filaments inserted at the corolla base with a free part c. $8 \mathrm{~mm}$ long, upper half swelling greatly to almost 5 times larger than the lower half, curved and forming a knee, with some hairs; staminodes 3, linear, c. $3 \mathrm{~mm}$ long. Gynoecium c. $12 \mathrm{~mm}$ long, $1.2 \mathrm{~mm}$ wide at the ovary base; ovary extending into a short style, curved towards the anthers; stigma not larger than style. Fruit a linear capsule, 3-5 cm long, $2 \mathrm{~mm}$ in diameter, spirally twisted, glabrous. Seeds narrowly ellipsoid, c. $0.5 \times 0.15 \mathrm{~mm}$.

Distribution. Burma, China, Thailand and Vietnam.

Habitat and ecology. On limestone substrates inside forest or scrub.

Proposed IUCN conservation assessment. Least Concern (LC). This species has been collected at many sites over a wide area and there are no major threats.

Additional specimens examined. Burma. Maymyo $\left[22^{\circ} 05^{\prime} \mathrm{N} 96^{\circ} 33^{\prime} \mathrm{E}\right]$, Ani Sakan Falls, $15 \mathrm{x}$ 1911 (fr), J.H. Lace 5502 (E); Maymyo, Gokteik Gorge, 500 m, 2 viii 1908 (fl), J.H. Lace 4158 (E); Maymyo, Urtrin, 1000 m, vi 1916 (fr), J.H. Lace 130 (E); S Shan States, 1000 m, vii 1909 (fl), R.W. MacGregor 554 (E).

China. Guangxi: 125 m, 24 iv 1981 (fl), D. Fang et al. 24985 (PE). Guizhou: Gan-Chouen [An1shun4] [26 $13^{\prime} \mathrm{N} 105^{\circ} 55^{\prime} \mathrm{E}$ ], 19 ii 1921 (fl), J. Cavalerie 2914 (P); Pinfa [Dai4hua4]

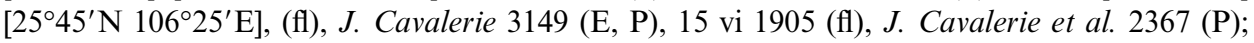
Mont du Collège [vicinity of Guiyang nearby a university?] [26 $32^{\circ} \mathrm{N} 106^{\circ} 41^{\prime} \mathrm{E}$ ], 5 vii 1900 ,

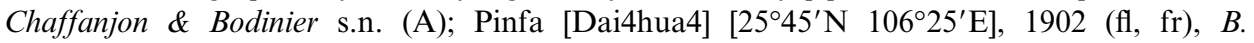
Chaffanjon 560 (E); 5 v 1898 (fl), B. Chaffanjon 2312 (E, P); 26 v 1898, B. Chaffanjon s.n. (P); Guiyang [26³2'N 106²4'E], H.C. Chow s.n.; vii 1905 (fl), J. Esquirol 398 (E); vi 1909 (fl), $J$. Esquirol 1568 (E); Ku-kai-shan, Tating [Da4tang2, close to Du1yun2] [26 $20^{\prime} \mathrm{N} 108^{\circ} 05^{\prime} \mathrm{E}$ ],

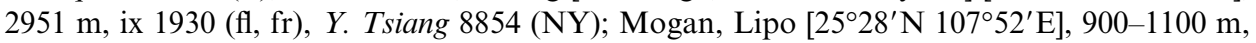
10-25 xii 1985 (fr), Z.R. Xu L1132 (SYS, US). Hubei: Shennongjia, EW running side Canyon or the E side of the Songlo River E of Jingyin $\left[31^{\circ} 30^{\prime} \mathrm{N} 110^{\circ} 30^{\prime} \mathrm{E}\right], 1050 \mathrm{~m}, 22$ ix $1980, B$. Bartholomew et al. (SINO-US) 1715 (A, E); Patung Hsien $\left[31^{\circ} 02^{\prime} \mathrm{N} 110^{\circ} 23^{\prime} \mathrm{E}\right], 15$ vi 1934 (fl, fr), H.C. Chou 506 (E, NY); Yichang [30 $\left.41^{\prime} \mathrm{N} 111^{\circ} 18^{\prime} \mathrm{E}\right]$, x 1887 (fl), A. Henry 3958 (E, GH, P, US, W), v 1888 (fl, fr), A. Henry 4158 (P, US), 1885-1888 (fl), A. Henry 6017 (E, P, US), iii 1889 (fl), A. Henry s.n. (P), $1885-1888$ (fl, fr), A. Henry 6071 (US); Fangxian $\left[32^{\circ} 05^{\prime} \mathrm{N}\right.$ $\left.110^{\circ} 41^{\prime} \mathrm{E}\right], 5$ vi 1982 (fr, fl), Z.D. Jiang \& G.F. Tao 364 (E, NY); Xuanen [3001'N 109²8'E], 800-900 m, (fr), H.J. Li 3851 (PE); Nanto [Nan2jin1guan1, close to Yi2chang1] [30 $45^{\prime} \mathrm{N}$ $\left.111^{\circ} 12^{\prime} \mathrm{E}\right]$, 5 vi 1899-1911 (fl), E.H. Wilson 859 (E, NY, P, US, W). Sichuan: District de 
Tchen-Keou-Tin [Jiang1kou3zhen4] [ $\left.31^{\circ} 10^{\prime} \mathrm{N} 118^{\circ} 52^{\prime} \mathrm{E}\right]$, (fl, fr), R.P. Farges 1172 (A, P, US, W), 1400 m, 1 vii 1892 (fl), R.P. Farges 1192 (P), 1895-1897 (fl), R.P. Farges s.n. (E, IBSC, P, US); S Wushan [31 $\left.06^{\prime} \mathrm{N} 109^{\circ} 51^{\prime} \mathrm{E}\right]$, v 1910 (fl), E.H. Wilson s.n. (E). Yunnan: Western flank Zali, c.3300 m, ix 1917 (fr), G. Forrest 15565 (E); Mikong-Salwin divide [26³0’ N], 3000 m, vii 1919 (fl, fr), G. Forrest 18259 (E); Shweli-Salwin Divide (= Mekong-Salwin divide?)

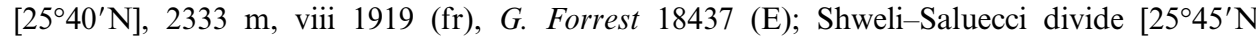
985'ㄹ, 2666 m, x 1924 (fr), G. Forrest 25309 (E); (fl, fr), A. Henry 9836 (NY); (fl, fr), A.

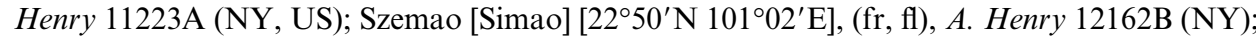
Szemao [Simao], (fl, fr), 1200-1500 m, A. Henry 12162A (NY, US); Collines arides, de Pa-Eulgai, 790 m, vi year? (fl), R.P. Maire s.n. (P); Rochers des mont. a Sau-Kwr, 2690 m, (fl), R.P.

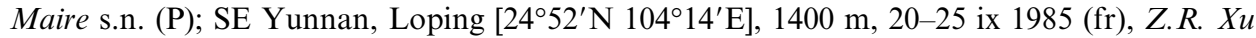

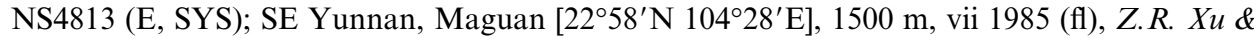
Chen GL3809 (E, SYS); Chengkang Snow Ranges Sangeorshan [ $\left.30^{\circ} \mathrm{N} 120^{\circ} \mathrm{E}\right], 2300 \mathrm{~m}, 30$ vii 1938 (fl), T.T. Yu 17103 (E).

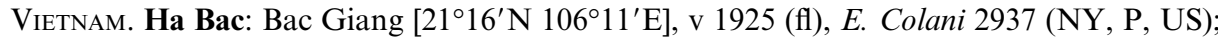

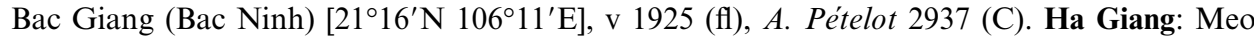
Vac District, Sung Chang, vicinity of Lu Lu Phin village, $23^{\circ} 11^{\prime} \mathrm{N} 105^{\circ} 18^{\prime} \mathrm{E}, 1350-1450 \mathrm{~m}, 29$ iv 1999 (fl), P.K. Loc et al. CBL1826 (AAU); Yen Minh District, La Va Chai, vicinity of Ngan

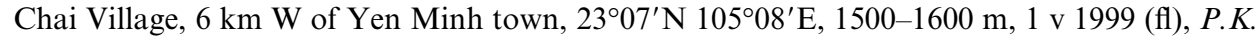
Loc et al. CBL1894 (AAU); Dong Van District, Ho Quang Phin, Vicinity of Ta Xa Village,

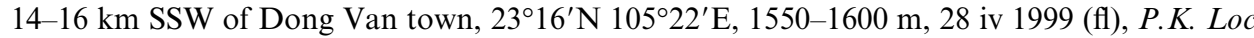

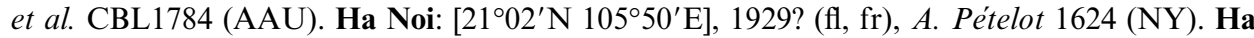
Tay: Mt. Bavi [21 $\left.03^{\prime} \mathrm{N} 105^{\circ} 22^{\prime} \mathrm{E}\right], 800 \mathrm{~m}, 16$ vi 1886 (fr), Balansa 4304 (E, P). Hoa Binh: Mai Chau District, Pa Co Village, $20^{\circ} 44^{\prime} \mathrm{N} 104^{\circ} 57^{\prime} \mathrm{E}$, Nguyen Tien Hiep NTH2108 (E). Lao Cai:

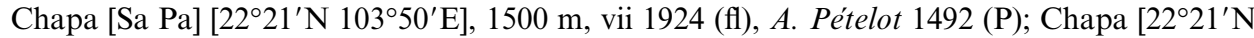
$\left.103^{\circ} 50^{\prime} \mathrm{E}\right]$, vii 1924 (fr, fl), A. Pételot 1605 (HNU, P); Chapa [22 $\left.21^{\prime} \mathrm{N} 103^{\circ} 50^{\prime} \mathrm{E}\right]$, iv 1925 (fr,

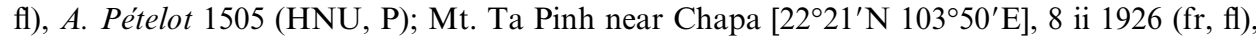
E. Poilane 12770 (P). Thanh Hoa: Thanh Hoa $\left[20^{\circ} 00^{\prime} \mathrm{N} 105^{\circ} 30^{\prime} \mathrm{E}\right], 100 \mathrm{~m}, 27$ i 1931 (fr), E. Poilane $18948(\mathrm{P})$.

This is a species comparable to Paraboea swinhoei and P. multiflora in its large populations and widespread distribution. The species is very diverse in leaf morphology and habit but is consistent in characters such as the inflorescence structure, the numerous large membranous bracts, and the large membranous obtrapeziform or obovate calyx lobes. The large calyx lobes are unique in the genus which is possibly why it has been treated in separate genera in the past (Oliver, 1887; Stapf, 1913). The other flower characters are similar to the groups around Paraboea martinii and $P$. glabrisepala. These have a large corolla with a long tube and less distinctly lipped limbs. They also have a swollen and kneed filament with some pubescence, and the anthers have an aperture at the upper end. The subterminal cymose inflorescence is also characteristic for this species although it could be mistaken as terminal and cymose. However, when the infructescence is mature, the aborted terminal bud inbetween the two subterminal cymes is revealed. Because the terminal bud is aborted the subsequent growth is resumed from an axil below the previous flowering region.

76. Paraboea speciosa (Rech.) B.L.Burtt, Notes Roy. Bot. Gard. Edinburgh 41: 438 (1984). - Boea speciosa Rech., Oesterr. Bot. Z. 49: 145 (1899). - Type: Cult. 9 viii 1897 in Hort. Bot. Vindob., Acq. Journ. n. 1800 (holo WU). 
Leaf blade $7.5 \times 5.5 \mathrm{~cm}$, broadly elliptic, apex damaged, probably unequal-sided at base (leaf damaged), petiolate (petiole $3.5 \mathrm{~cm}$ ), upper surface glabrescent, lower surface with a brown matted indumentum. Inflorescence densely congested. Calyx divided to the base into 5 lobes, broadly oblong-truncate at the apex, lobes $6 \times$ $4 \mathrm{~mm}$. Corolla white, marked with anthocyanin near the tips of some lobes (probably the tips exposed in bud) and perhaps in the throat, glandular-puberulous inside around the mouth and in the throat, otherwise glabrous, c. $2.2 \mathrm{~cm}$ long, $1.5 \mathrm{~cm}$ in diameter (in pressed material). Anthers c.5 mm in diameter, cohering face to face, hard, yellow, fully exposed at corolla mouth. Staminodes 3, filiform.

Distribution. Unknown.

Habitat and ecology. Unknown.

Proposed IUCN conservation assessment. Data Deficient (DD). See discussion below.

The species was described from cultivated material from the Vienna University herbarium and so far no other records have been added to this species. There are also no records to show where the original seeds for the cultivation came from. It is also unfortunate that no successor of that cultivation has been reported in current botanical gardens. The type specimen, a leaf and several flowers remains the only material for this specific name. However, the broadly oblongtruncate calyx lobes are quite characteristic as very few species in this genus possess these kinds of lobes. It may be a relative of Paraboea burttii, which has the same shape of lobes, but that species has a different texture to and indumentum on the leaves.

77. Paraboea speluncarum (B.L.Burtt) B.L.Burtt, Notes Roy. Bot. Gard. Edinburgh 41: 438 (1984). - Boea speluncarum B.L.Burtt, Notes Roy. Bot. Gard. Edinburgh 31: 36 (1971). - Type: Sarawak, Gunong Subis, on soft tufa limestone at mouth of Niah Cave, 5 vi 1962 (fl, fr), B.L. Burtt \& P.J.B. Woods 2019 (holo E; iso E, SAR). Fig. 45.

Perennial herb with a woody stem; stem pendulous and branched, $60 \mathrm{~cm}$ long, $1 \mathrm{~cm}$ in diameter, internodes $\mathrm{c} .1 \mathrm{~cm}$ long, with a brownish orange matted indumentum. Leaves in whorls of 3, sessile, leaf base attenuate to the stem and then swelling, joining with each other and so forming conspicuous ring surrounding the stem, elliptic or narrowly so, sometimes appearing more or less obovate, 10-20 $\times 3$ $5.5 \mathrm{~cm}, 3-5$ times as long as wide, apex acute, margin entire, upper surface arachnoid, lower surface with a white matted indumentum; veins obscure above, raised beneath, lateral veins 10-20 pairs, tertiary venation obscure. Inflorescence a terminal panicle with a short underdeveloped flowering stem but rather well-developed cymes from the axils of the flowering stem near the terminal bud; the terminal bud visibly active when the plant is in flower and fruit [but we do not know if it is aborted after the current flowering season]; cymes normally equal to the leaves or shorter, rarely 


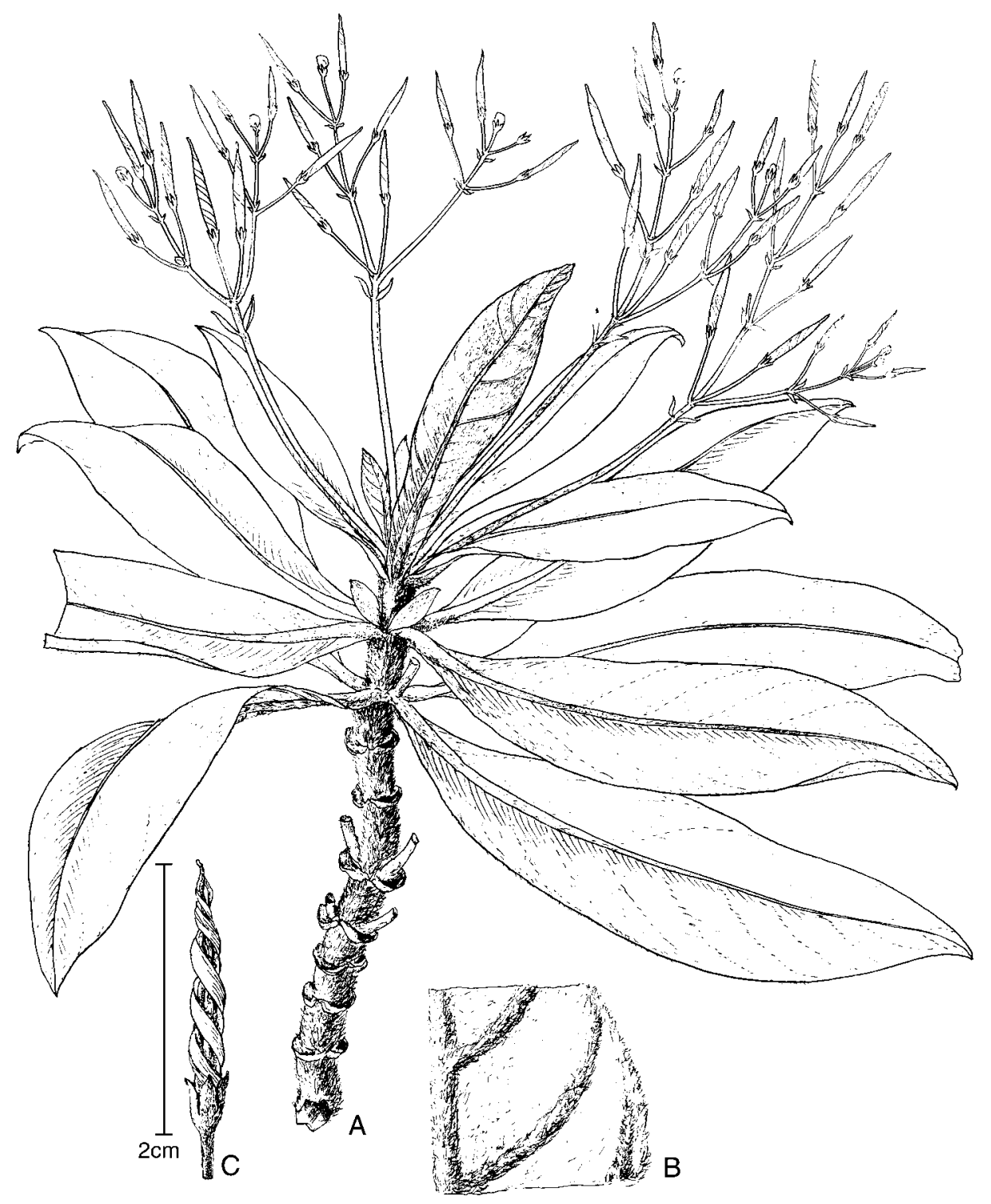

FIG. 45. Paraboea speluncarum (B.L.Burtt) B.L.Burtt. A, habit; B, underside of leaf; C, fruit.

longer, 8-13 cm long, c. $3 \mathrm{~cm}$ wide, several-flowered (normally $<10$ ), with a white matted indumentum except on corolla, stamen and gynoecium; peduncle c.5-7 cm long, peduncle bracts ovate, $5 \times 2.5 \mathrm{~mm}$; pedicel c. $5 \mathrm{~mm}$ long, pedicel bracts sepallike or indistinct. Calyx c. $3 \mathrm{~mm}$ long, 5-lobed, lobes narrowly ovate, c. $3 \times 0.5$ $0.6 \mathrm{~mm}$, with a matted indumentum outside. Corolla blue-violet, glabrous, c. $7 \mathrm{~mm}$ long, $15 \mathrm{~mm}$ across; tube $2 \mathrm{~mm}$ long, limb 2-lipped; upper lip with 2 lobes, rounded, 
c. $6 \times 6 \mathrm{~mm}$, lower lip c. $10 \mathrm{~mm}$ long with 3 lobes, middle lobe obovate, c. $6 \times 4.5 \mathrm{~mm}$, lateral lobes wide-ovate, c. $4 \times 4 \mathrm{~mm}$. Stamens 2 , staminodes not seen; anthers yellow, transversely ellipsoid, c. $1.5 \times 4 \mathrm{~mm}$, apex pointing towards the gynoecium, coherent with each other at both the apex and the base, opening in the centre of the anther locules, dorsifixed; filaments inserted at c. $2 \mathrm{~mm}$ from the corolla base with a free part c. $3 \mathrm{~mm}$ long, \pm twisted. Gynoecium c. $8 \mathrm{~mm}$ long; ovary ovoid, c. $1 \times$ $1 \mathrm{~mm}$; style c. $7 \mathrm{~mm}$ long, $0.3 \mathrm{~mm}$ wide; stigma slightly larger, capitate. Fruit a spirally twisted capsule, c.1-2 cm long, 1.5-2 $\mathrm{mm}$ in diameter, glabrous. Seeds narrowly ellipsoid, $0.6 \times 0.2 \mathrm{~mm}$.

Distribution. Malaysia: Sarawak.

Habitat and ecology. On limestone.

Proposed IUCN conservation assessment. Least Concern (LC). Although this species has not been collected often it is not infrequent in a protected area and there are no major threats.

Additional specimens examined. Malaysia. Sarawak: Niah Caves, 4th Division $\left[03^{\circ} 00^{\prime} \mathrm{N}\right.$ $\left.114^{\circ} 00^{\prime} \mathrm{E}\right], 166$ m, 9 vi 1962 (fr), Alphonso \& Samsuri A.241 (A, E, L, SAR); Gua Pangomah, Gunong Subis, Niah Caves, Miri District, 25 iv 1972 (fl, fr), J.A.R. Anderson S31675 (A, E, K, L, SAR); Niah Caves on tufa stalactites overhanging mouth of cave, 3 vi 1962 (fl, fr), B.L. Burtt \& P.J.B. Woods 1992 (E); (fr), Cult. in E C4918 (E).

When Burtt (1971) published this species he compared it with Boea lanata Ridl. (= Paraboea lanata) and mentioned that both species shared axillary inflorescences. We believe that Paraboea speluncarum has closer relatives in Borneo, such as $P$. candidissima and its relatives, tropical species with a terminal panicle and a whorled leaf formation. Similarity in the inflorescences of Paraboea speluncarum and $P$. lanata is of superficial value. We cannot judge from the type whether this species has an axillary cymose or a terminal paniculate inflorescence but it is clear from the type that the inflorescence is not typically cymose for several cymes develop from the uppermost axils of a short flowering stem with the appearance of a terminal panicle. Whether the terminal bud remains active or is aborted after one flowering season cannot be answered from the specimen itself.

78. Paraboea suffruticosa (Ridl.) B.L.Burtt, Notes Roy. Bot. Gard. Edinburgh 41: 439 (1984). - Boea suffruticosa Ridl., J. Linn. Soc., Bot. 32: 518 (1896). - Type: Peninsular Malaysia, Langkawi, on small islands, ix 1890 (fl, fr), C. Curtis 2565 (lecto SING, designated by Burtt (1984: 439)). Fig. 46.

A bushy plant, with a branched stem, to $60 \mathrm{~cm}$ tall; flowering branches monocarpic (i.e. the flowering branches die back after fruiting); stem $5 \mathrm{~mm}$ in diameter, internodes $5 \mathrm{~mm}$ long or shorter, with a brownish matted indumentum when young, changing colour to dark brown when older. Leaves alternately congested close to the terminal bud of a branch, petiolate; petiole $0.5-1.5 \mathrm{~cm}$ long, with the same indumentum as that on the lower leaf surface; blades elliptic or narrowly so, 


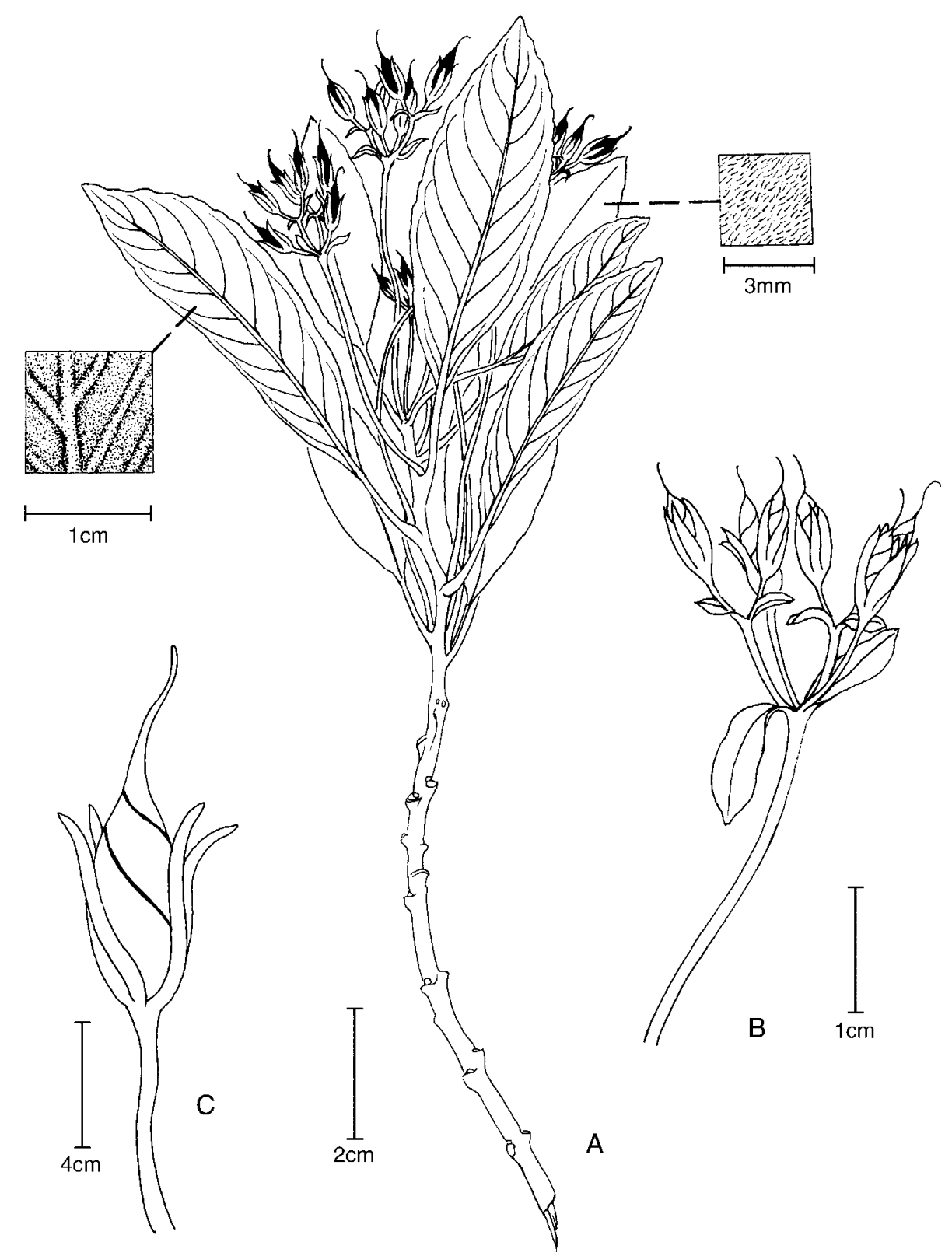

FIG. 46. Paraboea suffruticosa (Ridl.) B.L.Burtt. A, habit; B, infructescence; C, fruit.

3-7 $\times 1-2 \mathrm{~cm}, 2-5$ times as long as wide, apex obtuse, base angustate, margin entire, upper surface minutely pubescent, lower surface with a greyish or brownishorange matted indumentum; veins smooth above, raised beneath, lateral veins 6-10 pairs, tertiary venation invisible. Inflorescences subterminal cymose from a truly axillary flowering branch; cymelets growing in the axils near the apical bud of the 
flowering branch, resulting in a flowering branch appearing like a panicle, cymelets nearly equal in length to the leaves, c. $6 \mathrm{~cm}$ long, several-flowered (normally $<10$ ), with a brownish-orange matted indumentum except on the flower; peduncle $2-3 \mathrm{~cm}$ long; peduncle bract leaflet-like or narrowly ovate, up to $1 \mathrm{~cm}$ long, $4 \mathrm{~mm}$ wide; pedicel c. $5 \mathrm{~mm}$ long, pedicel bracts sepal-like. Calyx relatively long, c.5-8 $\mathrm{mm}$ long, 5-lobed to the base, lobes very narrowly linear, c. $0.3 \mathrm{~mm}$ wide, indumentum brownish-orange and matted. Corolla white, glabrous, c. $6 \mathrm{~mm}$ long, $7 \mathrm{~mm}$ across; tube c. $2 \mathrm{~mm}$ long, limb 2-lipped; upper lip with 2 lobes, lobes widely ovate, c. $2.5 \times$ $4 \mathrm{~mm}$, lower lip with 3 lobes, middle lobe ovate, c. $3 \times 2.5 \mathrm{~mm}$, lateral lobes rounded, c. $2.5 \times 3.5 \mathrm{~mm}$. Anthers transversely ellipsoid, c. $1.5 \times 2.8 \mathrm{~mm}$, opening in the centre of the anther locules, coherent with each other at the apex and the base, apex turned towards the gynoecium, dorsifixed; filaments inserted at c. $1 \mathrm{~mm}$ from the corolla base with a free part c. $1.5 \mathrm{~mm}$ long. Gynoecium c. $5 \mathrm{~mm}$ long; ovary ovoid, c. $1 \times 0.8 \mathrm{~mm}$, pubescent; style distinct, much narrower than the ovary; stigma not much larger than style. Fruit a narrowly ovoid capsule, c. $1 \mathrm{~cm}$ long or slightly shorter, $2 \mathrm{~mm}$ in diameter, glabrous, spirally twisted. Seeds compressed-ellipsoid, $0.6 \times 0.2 \mathrm{~mm}$.

Distribution. Peninsular Malaysia.

Habitat and ecology. On limestone.

Proposed IUCN conservation assessment. Least Concern (LC). This species has been collected at several sites on Langkawi and neighbouring islands and there are no major threats.

Additional specimens examined. Malaysia. Kedah: Langkawi: P. Dayang Bunting, S end, rocks above SW corner of lake $\left[06^{\circ} 13^{\prime} \mathrm{N}\right.$ 99 $\left.49^{\prime} \mathrm{E}\right], 29$ iv 1962 (fr), B.L. Burtt \& P.J.B. Woods 1763 (E); Langkawi Main island, $\mathrm{N}$ end, limestone hill, $\mathrm{N}$ Bank S Kisap [06 $\left.21^{\prime} \mathrm{N} 99^{\circ} 52^{\prime} \mathrm{E}\right], 30$ iv 1962 (fr), B.L. Burtt \& P.J.B. Woods 1774 (E); Batu Puteh, 20 xi 1941 (fl, fr), E.J.H. Corner s.n. (SING); Pulau Kedrah, 17 xi 1941 (fr), E.J.H. Corner 37811 (K, SING); small island N of Kuah, xi 1901 (fl, fr), C. Curtis 3682 (K, SING); Pulau Langkawi, East coast $\left[06^{\circ} 21^{\prime} \mathrm{N}\right.$ 9955'E], 19 viii 1972 (fl), E. Soepadmo \& Mahmud 1250 (L); P. Timun [06 $18^{\prime}$ N 9955'E], 19 viii 1972 (fr, fl), B.C. Stone 11007 (E).

This species is similar to Paraboea lancifolia but is easy to distinguish by its long and linear calyx lobes that are almost as long as the capsule. The inflorescences of Paraboea suffruticosa are described above as axillary although taking the branch as a whole it does appear somewhat like a terminal panicle. Paraboea lancifolia is described as having a paniculate inflorescence from an axillary flowering branch but the distinction is one only of appearance and is not a hard and fast difference. Both species were collected from the Langkawi Islands but isolated from each other on different small islands.

79. Paraboea swinhoei (Hance) B.L.Burtt, Notes Roy. Bot. Gard. Edinburgh 41: 439 (1984). - Boea swinhoei Hance, Ann. Sci. Nat. ser. 5, 5: 231 (1966). - Type: 
Formosa [Taiwan], Takow-Taiwan, Apes Hill, Bush [Ga01xiong2 City, Shou4shan1] [22 $06^{\prime} \mathrm{N} 120^{\circ} 03^{\prime} \mathrm{E}$ ], 1863 (fr), R. Swinhoe 62 (lecto BM, designated here; iso K). Fig. 47.

Boea swinhoei var. diffusior C.B.Clarke in A.DC. \& C.DC., Monogr. Phan. 5: 142 (1883). - Type: Borneo, Korthals (?Blume) s.n. (Herb. Lugd. Batav. No. 182) (lecto L [acc. no. 903307-283], designated here; iso L [acc. no. 903307-284], K [sub Clarke No. 182)]).

Boea kerrii Craib, Bull. Misc. Inform. Kew 1916: 267 (1916). - Paraboea kerrii

(Craib) B.L.Burtt, Notes Roy. Bot. Gard. Edinburgh 41: 430 (1984). - Type: Thailand, Doi Sutep, 600 m, Kerr 1973 (lecto ABD, designated by Burtt (1984: 430); iso $\mathrm{E}, \mathrm{K}$ ).

Perennial herb with a woody stem c.50 $\mathrm{cm}$ tall, $3-4 \mathrm{~mm}$ in diameter, internodes 1-5 cm long, with a yellowish matted indumentum when young and later glabrescent. Leaves opposite, petiolate; petiole 1-3 cm long with the same indumentum as that on the blades; blades ovate, narrowly ovate, or in some rare cases somewhat obovate, 4-14 $\times 2.5-7 \mathrm{~cm}$, apex acute, base rounded to truncate, sometimes very slightly cordate, margin more or less serrate, upper surface with some arachnoid covering when young and glabrescent when mature, lower surface with a yellowish matted indumentum; veins smooth above, raised beneath, lateral veins 5-11 pairs, tertiary venation obscure. Inflorescence a large terminal panicle comprised of axillary cymes, with a yellowish matted indumentum throughout except for the flower; flowering stem 15-25 cm long, internodes similar in length to those of the vegetative stem; floral leaves similar in size to the vegetative leaves; the cymes opposite to each other on the nodes of the flowering stem, many-flowered, up to $13 \mathrm{~cm}$ long, with peduncle bracts ovate, c. $3 \times 2 \mathrm{~mm}$, and pedicel bracts sepal-like; pedicel 5-8 mm long. Calyx campanulate, 1.5$2.5 \mathrm{~mm}$ long, 5-lobed to the base, lobes narrowly oblong, $2.3 \times 1 \mathrm{~mm}$ with a matted indumentum outside, glabrous inside. Corolla white, glabrous, c. $5 \mathrm{~mm}$ across when open, \pm campanulate, $6 \mathrm{~mm}$ long; tube c. $4 \mathrm{~mm}$ long, limb \pm 2 lipped; upper lip 2-lobed, lobes widely ovate, $2.5 \times 3.5 \mathrm{~mm}$, lower lip 3-lobed, middle lobe $2 \times 3.5 \mathrm{~mm}$, lateral lobes $2.5 \times 2.5 \mathrm{~mm}$. Stamens 2 , staminodes 3 ; anthers transversely ellipsoid, $1.5 \times 3.5 \mathrm{~mm}$, coherent with each other, \pm dorsifixed; filaments short, c. $3 \times 0.8 \mathrm{~mm}$, curved to turn the apex of the anthers towards the gynoecium, minutely pubescent; sometimes staminodes developing into half the size of the fertile anthers (which shows the origin of this group from 5 fertile stamens). Gynoecium c. $7 \times$ $1.2 \mathrm{~mm}$; stigma capitate, sometimes visibly 2-lobed, not much larger than style. Fruit linear, very slender, c. $2 \mathrm{~cm}$ long, $1 \mathrm{~mm}$ in diameter, glabrous, with a degree of twisting. Seeds compressed, ellipsoid, c. $0.7 \times 0.2 \mathrm{~mm}$.

Distribution. Southern China, Taiwan, Vietnam, Burma, Thailand, Borneo, Java (and Sulawesi?).

Habitat and ecology. On limestone. 


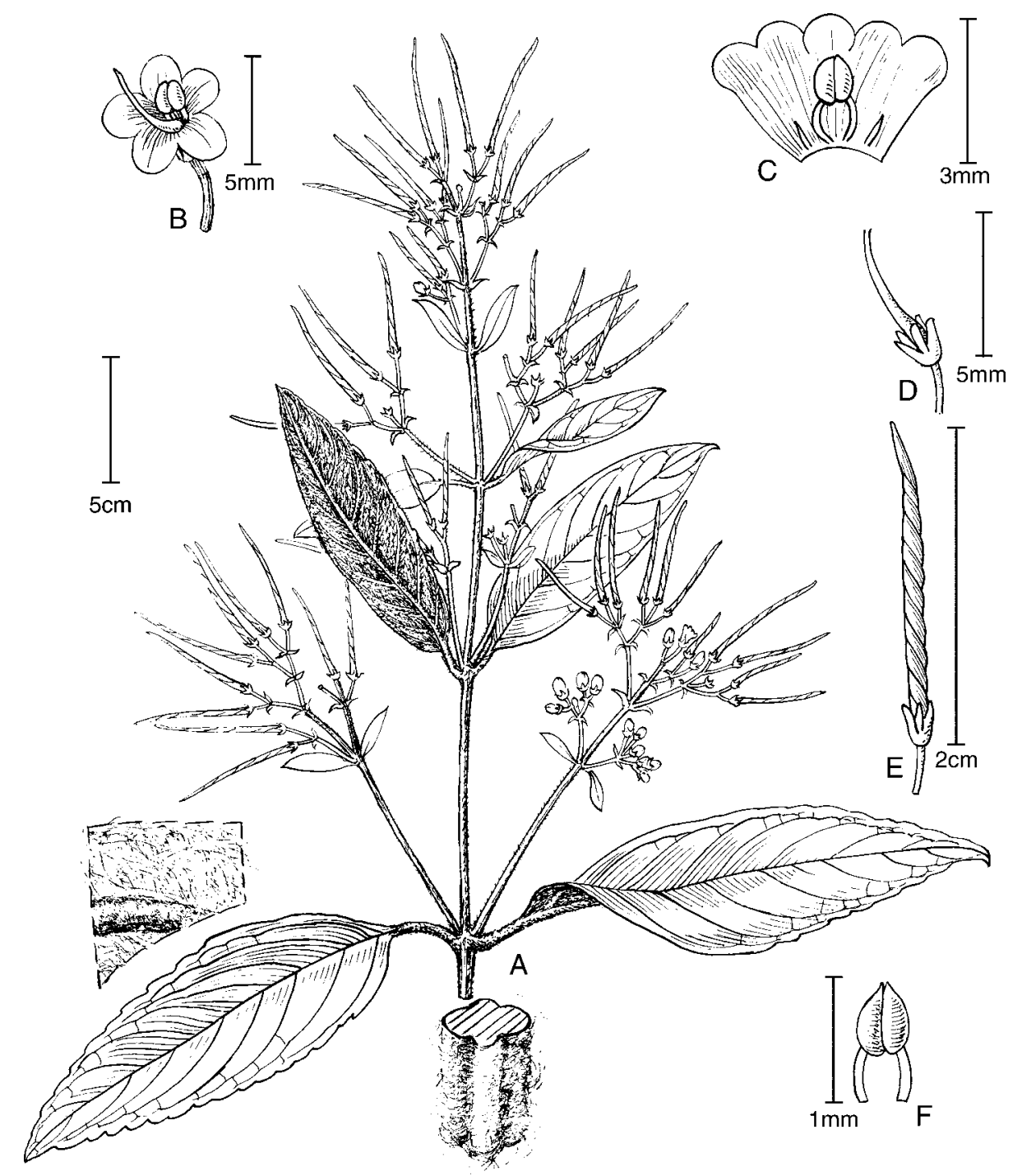

FIG. 47. Paraboea swinhoei (Hance) B.L.Burtt. A, habit; B, flower; C, corolla opened out; D, pistil; E, fruit; F, stamens.

Proposed IUCN conservation assessment. Least Concern (LC). This species has been collected at many sites over a wide area and there are no major threats. This species was, however, included in Pooma (2005) as threatened in Thailand.

Additional specimens examined. Burma. Rangoon $\left[16^{\circ} 47^{\prime} \mathrm{N} 96^{\circ} 10^{\prime} \mathrm{E}\right]$, v 1935 (fr), F.G.

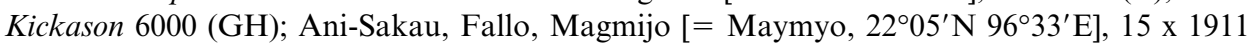
(fr), J.H. Lace 5501 (E). 


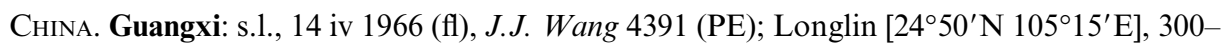
550 m, 12 vii 1957 (fr, fl), X.Q. Chen 13224 (IBSC); 15 Li S. of Nee Bai, Border of Kweichow, on exposed cliff, low shrub $2 \mathrm{ft},\left[24^{\circ} 50^{\prime} \mathrm{N} 106^{\circ} 08^{\prime} \mathrm{E}\right], 2300 \mathrm{ft}$ (c.700 m), 29 vi 1928 (fr, fl), R.C.

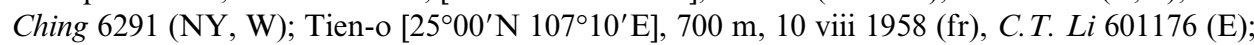
Daxin [22 $\left.52^{\prime} \mathrm{N} 107^{\circ} 10^{\prime} \mathrm{E}\right], 10$ iv 1981 (fl), H.N. Qin 81 (PE); Nam Tan, $2500 \mathrm{ft}$ (c.750m), 13 vii 1937, C. Wang 41150 (A).

Taiwan. s.1., ii 1924 (fr), A. Fauquier 554 (P); Busai, 1000 m, v-viii 1934 (fl), J.L. Gressitt 300 (L, MICH, NY, S); Canyon side [Not exact locality], 700 m, v-viii 1934 (fl), J.L. Gressitt 363 (NY); Mt. Kappan, vii 1914 (fl), B. Hayata 241 (UC); ibid., (fr, fl), A. Henry 897 (MO, NY, US); ibid., (fr, fl), B. Hayata 8937 (MO); ibid., iv 1895 (fr), B. Hayata 897A (BM);

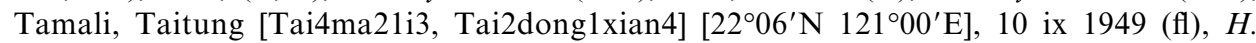
Keng K1382 (L); Chung-hsing, Tahu, Miao-li Hsien [Da4hu2xiang1, Mia021i4xian4] $\left[24^{\circ} 05^{\prime} \mathrm{N} 120^{\circ} 09^{\prime} \mathrm{E}\right], 13$ vii 1965 (fr, fl), Liao \& Kuo 1636 (L); Apes' Hill, Takow, $\left[22^{\circ} 06^{\prime} \mathrm{N} 120^{\circ} 03^{\prime} \mathrm{E}\right.$ ], 19 vi 1892 (fl), Playfaio 6363 (P); Hab. mt. Taihei [Yi21an2xian4,

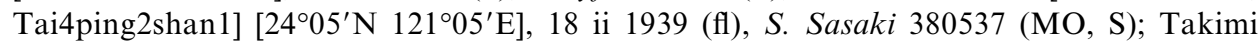

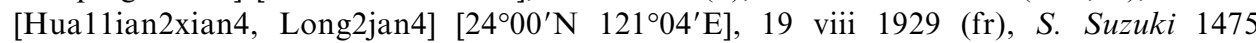
(MO, S); Cholan, Miaoli Co. roadside [?Da4hu2xiang1, $24^{\circ} 05^{\prime} \mathrm{N} 120^{\circ} 09^{\prime} \mathrm{E}$ ], 29 vi 1984 ,

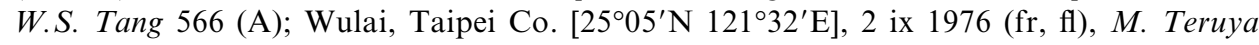
$130 \mathrm{~F}(\mathrm{CM})$.

IndONeSIA. Borneo: Blume 182 (L); 10 ii 1882 (fl), Korthals 182 (K). Java: s.l., 18?? (fl, fr), Blume 241 (L). The Blume 182 and the Korthals 182 specimens may be the same collection and, therefore, all type material.

Philippines. Luzon: Pampanga, Mt. Arayat $\left[15^{\circ} 00^{\prime} \mathrm{N} 120^{\circ} 45^{\prime} \mathrm{E}\right]$, ix 1905 (fr, fl), E. D. Merrill

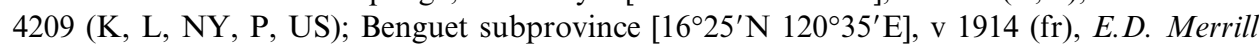
1754 (L, MO, NY, P); Mt. Trail 8-10 km Benguet subprovince [16²5'N 120³5'E], x 1929 (fl), T. Quisumbing 78085 (NY); Benguet subprovince, Twin Peaks, Northern Luzon, 8 ix 1904 (fr, fl), R.S. Williams 938 (NY); Central Luzon [Benguet? 16²5'N 120³5'E], 26 v 1990 (fr), Loher 1552 (US); Mt. Nagapatan, Ilocos Norte Province [180.' $\left.\mathrm{N} 120^{\circ} 46^{\prime} \mathrm{E}\right]$, viii 1918, M. Ramos

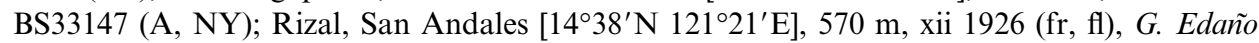

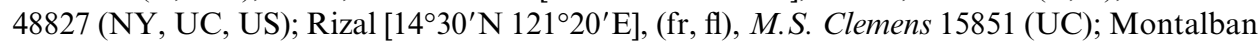
(Rizal), 4 v 1906 (fr), Loher 6671 (K); Rizal, viii 1913 (fr, fl), Loher 14825 (UC); 'Monteoh la bueva' on Montalban, N. bam bus region, 300-400 m, 16 x 1890 (fl, fr), Loher 1552 (K); Rizal, xii 1915 (fr), M. Ramos 24076 (US); Rizal, Mt. Susong-Dalaga, viii 1917 (fl), M. Ramos \& Edano 29286 (K, L, P, US); Rizal, Mt. Susong-Dalaga, viii 1917 (fl), M. Ramos \& Edano 107 (P). Mindoro: Mt. Yagaw, Eastern slope [12 $\left.24^{\prime} \mathrm{N} 121^{\circ} 18^{\prime} \mathrm{E}\right], 500 \mathrm{~m}$, xii 1952 (fr, fl), M.D. Sulit \& Conklin 4774 (PNH16956) (A, K, L, PNH).

TAIwan. Hualien Hsien: Hsiulin Hsiang, Taroko National Park, mountain trail between Taroko and Tali, 100-200 m, 20 vii 1992 (fl, fr), W.P. Leu et al. 1433 (E).

Thailand. Chiangmai: Doi Sutep $\left[18^{\circ} 55^{\prime} \mathrm{N} 99^{\circ} 00^{\prime} \mathrm{E}\right], 1000 \mathrm{~m}, 31$ x 1967 (fr), B. L. Burtt 5578 (ABD, E); 1976 (fl), Cult. in E C4029 (E); Doi Sutep, x 1914 (fr), Y. Jung s.n. (BKF); Doi Sutep, 4 vii 1958 (fl), T. Sorensen et al. 3888 (BKF, C, K); Doi Sutep, 1100 m, 30 vii 1958 (fl), T. Sorensen et al. 4543 (C, K). Khonkaen: Pha Nok Khao [16³0'N 10300'E], 800 m, 9 ix 1963 (fr, fl), T. Smitinand \& H. Sleumer 1130 (BKF, E, K, L). Lampang: Doi Luang National Park, Wahng Cayo Falls, 600 m, 8 viii 1997, Maxwell 97-830 (A).

Vietnam. Cao Bang: Ha Lang District, Thang Loi, vicinity of Lung Sam Village, $22^{\circ} 45^{\prime} \mathrm{N}$ 106 $42^{\prime}$ E, 650-700 m, 24 iv 1999, P.K. Loc et al. CBL1684 (AA). Vinh Phu: Roches NotreDame, near Tu Vu $\left[21^{\circ} 01^{\prime} \mathrm{N} 105^{\circ} 19^{\prime} \mathrm{E}\right], 1887$, Balansa 4303 (P).

Hance spelled the specific epithet as 'swinhoii'. Being a Latin scholar he translated Swinhoe into Latin as Swinhoius and so 'swinhoii' for 'of Swinhoius'. However, 
under Art. 60.7 of the ICBN (McNeill et al., 2006), this must be corrected to 'swinhoei'.

There may be arguments for recognising Boea swinhoei var. diffusior and Boea kerrii as varieties under Paraboea swinhoei. Craib (1916) compared his Boea kerrii with Hance's Boea swinhoei and listed some quantitative differences: leaves larger, pedicels longer, and so on. However, there are no qualitative differences and the quantitative characters have a large overlap. Thus, we reduce Craib's species to synonymy although further collections may suggest that it deserves varietal recognition. No significant differences can be identified between Boea swinhoei var. diffusior and typical Paraboea swinhoei, except that the leaf blades are slightly larger and slightly more obovate, c. $12 \times 5 \mathrm{~cm}$, with a longer acumen, and that the inflorescence is slightly more spreading. However, again the characters overlap with the type variety and it is here reduced to synonymy. There is an uncertain record from Sulawesi, Rant 53 (BO) from Bantimocroeng (southwest Sulawesi), in which the upper leaf surface is pubescent rather than being glabrescent.

Paraboea swinhoei has the widest distribution of any species in the genus but further collections are necessary in parts of its range, particularly in Borneo and Java, to fully understand its variation.

80. Paraboea tarutaoensis Z.R.Xu \& B.L.Burtt, Edinburgh J. Bot. 48 : 13 (1991).

- Type: Thailand, Satun Province, Tarutao Island, Mallacca ck. [06 $50^{\prime} \mathrm{N}$ $99^{\circ} 30^{\prime} \mathrm{E}$ ], on limestone rocks, in $30 \mathrm{~m}$ tall thick forest, 12 x 1979 (fr), Congdon 10 (holo E; iso A, AAU, PSU). Fig. 48.

Perennial herb with a climbing stem up to $35 \mathrm{~cm}$ long and c.2 $\mathrm{mm}$ in diameter; internodes c. 15-45 mm long. Leaves opposite, cauline; petiole $0.8-1.5 \mathrm{~cm}$ long; blade possessing a mixture of a matted indumentum and a long pubescence of branched hairs on the lower leaf surface, margin dentate. Inflorescence a cyme of very few flowers, shorter than the leaf. Flowers only known immature; corolla white, 2-lipped; the 2 stamens united at their apex, filaments more or less swollen. Fruit not twisted, slender, 2-4 cm long, c. $2 \mathrm{~mm}$ in diameter.

Distribution. Thailand: Tarutao Island.

Habitat and ecology. Common on limestone.

Proposed IUCN conservation assessment. Least Concern (LC). Although this species has not been collected often it is reported as being common from a site that is protected. This species was, however, included in Pooma (2005) as threatened in Thailand.

Additional specimen examined. Thailand. Satun: Tarutao Island, c. $4 \mathrm{~km}$ south of the N. Cape of the island, on rocky cliff, 10-50 m in shrub vegetation, 11 i 1986 (fr), Kurzweil HK783 (WU).

In its multi-branched hairs, this species is similar to Paraboea vulpina, but with the long pubescence mixed in with a matted indumentum, this species may be related to 


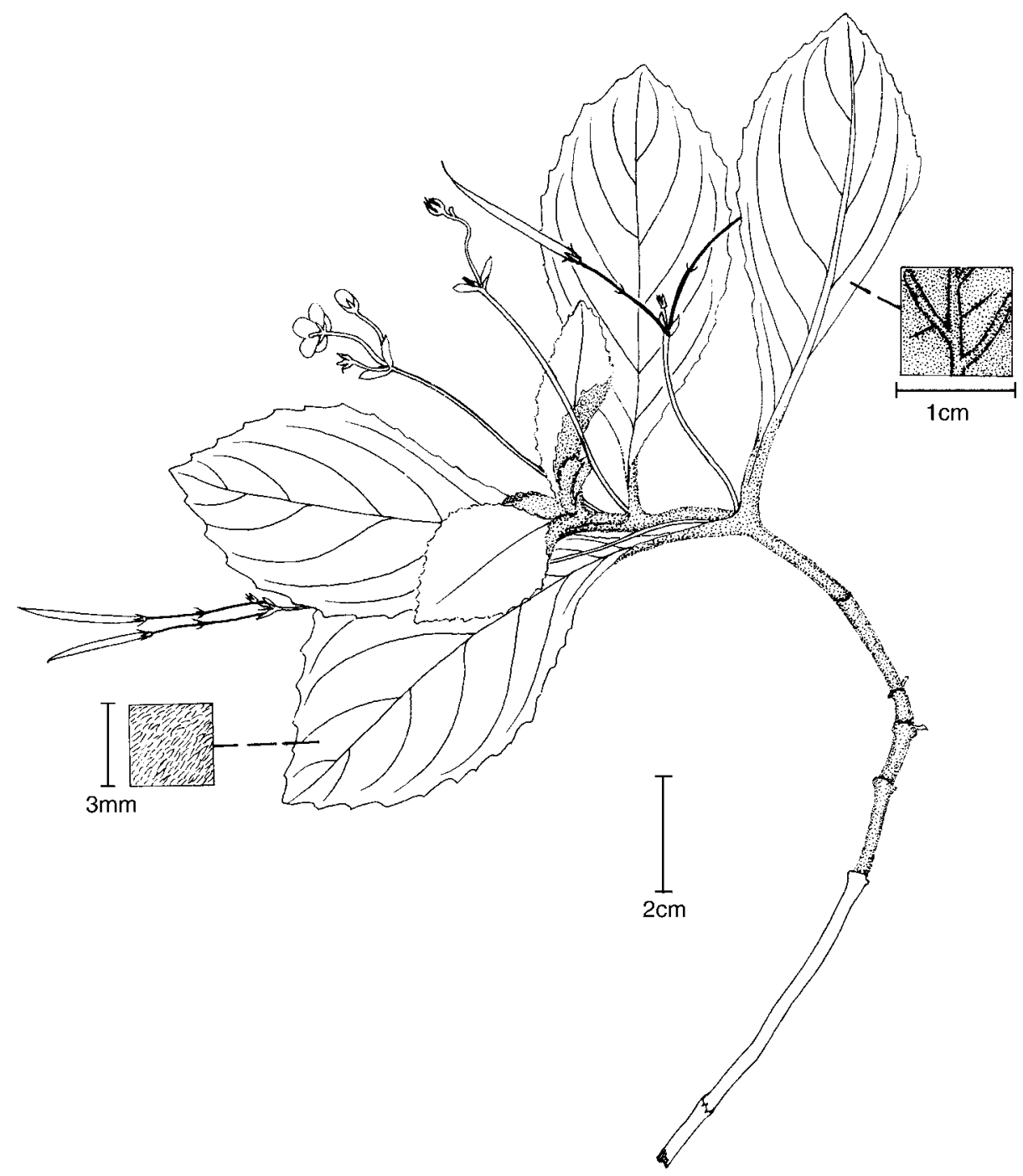

FIG. 48. Paraboea tarutaoensis Z.R.Xu \& B.L.Burtt.

P. laxa. Although Paraboea laxa is recorded from the nearby Langkawi Islands it has never been found on Tarutao.

81. Paraboea thorelii (Pellegr.) B.L.Burtt, Notes Roy. Bot. Gard. Edinburgh 41: 439 (1984). - Boea thorelii Pellegr., Bull. Soc. Bot. France 73: 424 (1926). - Type: Laos, Champassak, Mt. Bassac [14 $\left.{ }^{\circ} 55^{\prime} \mathrm{N} 105^{\circ} 47^{\prime} \mathrm{E}\right]$, 1866-1868 (fr), M.L. Thorel 2352 (lecto P, designated by Burtt (1984: 439); photo E).

Perennial herb with a very short stem, the whole plant c.30 $\mathrm{cm}$ tall including the inflorescence. Leaves oppositely congested near ground level, petiolate; petiole with 
two wings from the leaf base along the whole length of the petiole and joining each other across the stem; blades \pm elliptic, $11-19 \times 4-6.5 \mathrm{~cm}$, c. $2.5-3$ times as long as wide, apex acute, base long-attenuate, margin shallowly (or indistinctly) crenate, upper surface pubescent, lower surface with a thin matted indumentum; veins smooth above, raised beneath, lateral veins c.10 pairs, tertiary venation visibly reticulate. Inflorescence terminal paniculate, c. $25 \mathrm{~cm}$ long, $12 \mathrm{~cm}$ wide in fruit, with glandular hairs throughout except on the calyx and corolla; flowering stem with extended internodes, the lowest one c. $9 \mathrm{~cm}$ long, floral leaves much smaller than vegetative leaves, the two lowermost fertile leaves c. $1.5 \times 0.7 \mathrm{~cm}$; pedicels c. $10-15 \mathrm{~cm}$ long. Calyx glabrous or with few hairs outside, $1 \mathrm{~mm}$ long, 5-lobed to the base, lobes narrowly ovate. Corolla campanulate, $7 \mathrm{~mm}$ long, $7 \mathrm{~mm}$ wide; tube c. $3 \mathrm{~mm}$ long, limb with 2 similar lips; 5 lobes similar, wide-ovate, c. $4 \times 4 \mathrm{~mm}$. Stamens 2, staminodes not apparent; anthers transversely ellipsoid, c. $2.5 \times 3.2 \mathrm{~mm}$, coherent at the apex, pointing towards the gynoecium, opening at the apex, dorsifixed; filaments c. $2.5 \mathrm{~mm}$ long, inserted at c. $0.5 \mathrm{~mm}$ from the corolla base. Gynoecium c. $5 \mathrm{~mm}$ long; ovary ovoid, c. $3 \times 1 \mathrm{~mm}$; style distinct, c. $0.4 \mathrm{~mm}$ wide. Fruit a spirally twisted capsule, 2-3 cm long, glabrous. Seeds ellipsoid, $0.4 \times 0.1 \mathrm{~mm}$.

Distribution. Laos. So far known only from the type.

Habitat and ecology. Unknown.

Proposed IUCN conservation assessment. Critically Endangered (CR B1ab(ii,iii,v)) see conservation assessment section in introduction.

This species is similar to Paraboea glutinosa in habit and in the inflorescence but is easily distinguished by having a pubescence on the upper leaf surface and some glandular hairs on the inflorescence.

82. Paraboea trachyphylla Z.R.Xu \& B.L.Burtt, Edinburgh J. Bot. 48 : 13 (1991). - Type: Thailand, Surat Thani, Khao Lang Tao, $50 \mathrm{~km} \mathrm{~W}$ of Surat, road to Takuapah [09 $00^{\prime} \mathrm{N} 98^{\circ} 08^{\prime} \mathrm{E}$ ], 200-300 m, common on limestone, 26 ix 1963 (fl, fr), Smitinand, Sleumer et al. 1289 (holo E; iso A, B, BKF, C, E, K, L, P). Fig. 49.

Perennial caulescent herb; stem c. $3 \mathrm{~mm}$ in diameter; internodes 1-7 cm long, with a tawny matted indumentum when young and glabrescent when older. Leaves opposite, without a distinct petiole, slightly oblique, elliptic or nearly so, 3-17 $\times 1.5-$ $5 \mathrm{~cm}$, apex acute or obtuse, margin sparsely serrulate or nearly entire, base attenuate and forming 2 narrow wings on the indistinct petiole, upper surface minutely pubescent, lower surface with a tawny matted indumentum; veins smooth above, raised beneath, lateral veins 7-10 pairs, tertiary venation obscure. Inflorescences axillary below the terminal bud (or subterminal), cymose, usually two in opposite axils, 11-25 $\times 5-15 \mathrm{~cm}$, many-flowered, totally glabrous or with a tawny matted indumentum except on the flower; some branches of the cyme tending to develop monochasially, forming racemose branches with no bifurcations; peduncle $6-15 \mathrm{~cm}$ 


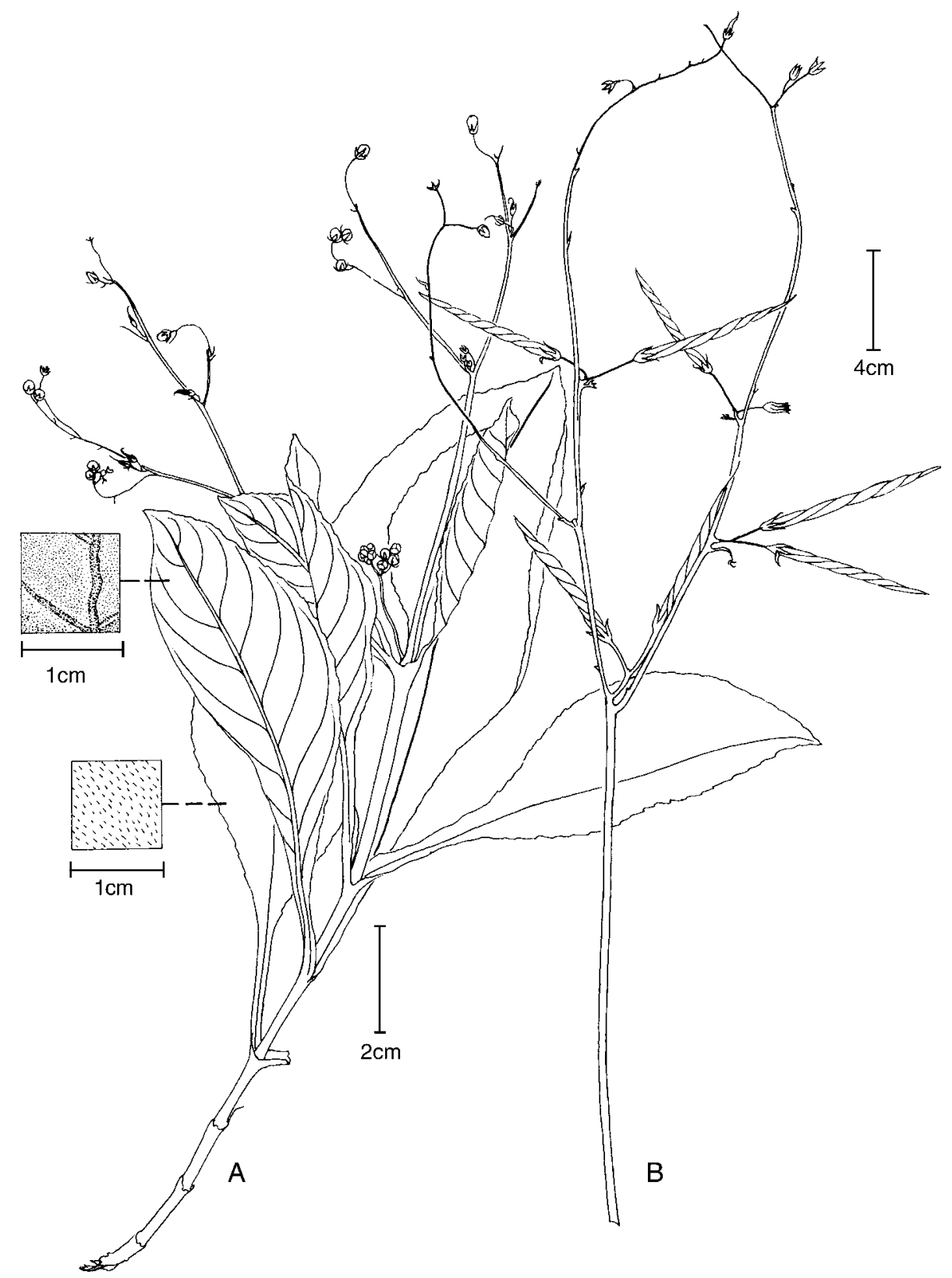

FIg. 49. Paraboea trachyphylla Z.R.Xu \& B.L.Burtt. A, habit; B, infructescence.

long, peduncle bracts very small and sepal-like or a little larger; pedicel bracts even smaller, pedicel 2-6 mm long. Calyx 2-3.2 mm long, 5-lobed, lobes ovate, c.1.5-3 times as long as wide, glabrous or with a matted indumentum on the outside. Corolla pale pinkish or white, c. $4 \mathrm{~mm}$ long, $5 \mathrm{~mm}$ across; tube c. $1.5 \mathrm{~mm}$ long, limb 2-lipped; 
upper lip 2-lobed, lobes wide-ovate, $2.5 \times 2.7 \mathrm{~mm}$, lower lip 3-lobed, two lateral lobes similar in size and shape to the upper lip lobes, middle one slightly obovate. Anthers transversely ellipsoid, $1.6 \times 3.2 \mathrm{~mm}$, coherent with each other at the apex, opening in the centre of the anther locules, basifixed; filaments c. $1 \mathrm{~mm}$ long. Gynoecium c.3.5 mm long; ovary c. $1.2 \mathrm{~mm}$ wide; stigma capitate, not larger than style. Fruit a linear capsule, $1.3-1.6 \mathrm{~cm}$ long, $1.2-1.5 \mathrm{~mm}$ in diameter, glabrous, spirally twisted. Seeds narrowly ellipsoid, c. $0.5 \times 0.15 \mathrm{~mm}$.

Distribution. Thailand.

Habitat and ecology. On limestone.

Proposed IUCN conservation assessment. Endangered (EN Blab(ii,iii,v)). This species is only known from two localities from neighbouring provinces. The extent of occurrence is $<5000 \mathrm{~km}^{2}$ and the known localities few, justifying the EN status. This species was also included in Pooma (2005) as threatened in Thailand.

Additional specimens examined. Thalland. Surat Thani: Takuapah-Surat Thani road, 20$60 \mathrm{~km}$ from Takuapah, $08^{\circ} 53^{\prime} \mathrm{N} 98^{\circ} 21^{\prime} \mathrm{E}, 100-250 \mathrm{~m}, 14$ vii 1972 (fl), K. Larsen et al. 30949 (AAU, B, E, K, L). Phangnga: Tham Suwankuha, $08^{\circ} 15^{\prime} \mathrm{N} 98^{\circ} 40^{\prime} \mathrm{E}$, in rock crevices, $50 \mathrm{~m}$, 20 vii 1972 (fl), K. Larsen et al. 31181 (AAU).

See discussion under Paraboea variopila. The type specimen differs from the other two collections cited above in having a totally glabrous inflorescence and white flowers, whereas the other two collections have a tawny matted indumentum and pinkish flowers.

83. Paraboea treubii (H.O.Forbes) B.L.Burtt, Bot. J. Linn. Soc. 85: 25 (1982); Burtt, Notes Roy. Bot. Gard. Edinburgh 41: 440 (1984). - Boea treubii H.O.Forbes, J. Linn. Soc., Bot. 19: 297 (1882). - Type: Sumatra, Palembang, top of Mt. Karangnata [Karang Natoe] (limestone), near Napal Nitjin, $1000 \mathrm{ft}$ (c.300 m), 1880 (fl, fr), H.O. Forbes 3103 (holo BM; iso GH, L, P, SING). Fig. 50.

Paraboea culminicola K.G.Pearce, Gard. Bull. Singapore 57: 147 (2005). - Type: Malaysia, Sarawak, Fourth Division, Miri District, Southern slopes of Gunong Subis, near Sekaloh river, Sonny Tan \& E. Wright S27279 (holo SAR).

Perennial caulescent subshrub; stem up to $2 \mathrm{~m}$ tall, internodes $1.5-6 \mathrm{~cm}$ long, with a tawny matted indumentum. Leaves in whorls of 3-6, sessile or with a short petiole c. $2.5 \mathrm{~cm}$ long, narrow-elliptic or somewhat obovate, mature leaves c.20-35 $\times 5$ $7.5 \mathrm{~cm}, \mathrm{c} .3 .5-5$ times as long as wide, apex acuminate, base long-attenuate, margin entire, upper surface glabrous or with some arachnoid covering, sometimes with a matted pubescence above, lower surface with an appressed thick tawny or whitish matted indumentum; veins smooth above, raised beneath, lateral veins numerous, 20-40 pairs, 5-10 $\mathrm{mm}$ apart, tertiary venation obscure or reticulate. Inflorescence terminal, paniculate, large and spreading, 30-60 cm long, $30 \mathrm{~cm}$ wide, with a tawny or whitish matted indumentum throughout except on the corolla; flowering stems 


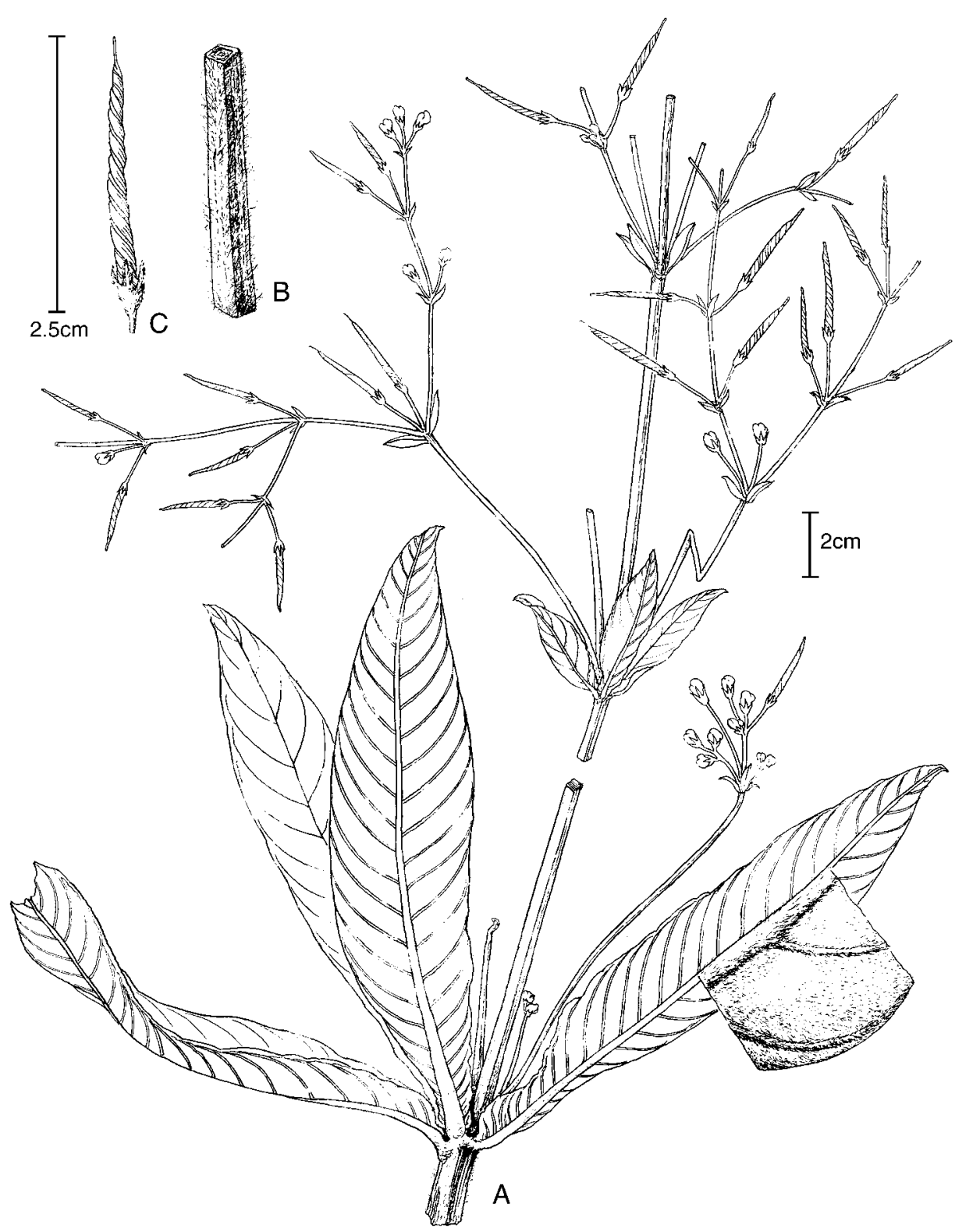

FIg. 50. Paraboea treubii (H.O.Forbes) B.L.Burtt. A, habit; B, section of stem; C, fruit.

with internodes normally c. $10-20 \mathrm{~cm}$ long, floral leaves much smaller than cauline ones, up to $4 \times 1.5 \mathrm{~cm}, 3-5$ cymes from each node; cymes long and spreading, c.10$30 \mathrm{~cm}$ long, many-flowered, with a peduncle up to $20 \mathrm{~cm}$ long, bracts narrow-ovate, 5-10 $\times 2-4 \mathrm{~mm}$; pedicel 5-15 mm long, with a sepal-like bract. Caly $\times 2-3 \mathrm{~mm}$ long, 5-lobed, lobes narrow-ovate, with a greyish matted indumentum outside, glabrous 
inside. Corolla pale purple, glabrous, c. $1 \mathrm{~cm}$ long, c. $1.4 \mathrm{~cm}$ across; tube c. $2.5 \mathrm{~mm}$ long, limb 2-lipped; upper lip c. $6 \mathrm{~mm}$ long, 2-lobed, lobes wide-ovate, c. $6 \times 7 \mathrm{~mm}$, lower lip $10 \mathrm{~mm}$ long, 3-lobed, lateral lobes wide-ovate, c. $5 \times 5 \mathrm{~mm}$, median one \pm obovate, c. $5 \times 4 \mathrm{~mm}$. Anthers transversely ellipsoid, c. $2.5 \times 5 \mathrm{~mm}$, coherent at the apex, opening in the centre of the anther locules, apex turned towards the gynoecium, dorsifixed; filaments inserted at the corolla base with a free part c. $3 \mathrm{~mm}$ long, margin crenate. Gynoecium c. $1.2 \mathrm{~cm}$ long, ovary ovate, c. $2 \times 1.2 \mathrm{~mm}$; style long and slender, c. $0.3 \mathrm{~mm}$ wide; stigma capitate, larger than style. Fruit a linear capsule, $1.3-3 \mathrm{~cm}$ long, $1.2-1.5 \mathrm{~mm}$ in diameter, glabrous, spirally twisted. Seeds narrow ellipsoid, compressed, c.0.7-0.8 $\times 0.1-0.2 \mathrm{~mm}$.

Distribution. Peninsular Malaysia, Sumatra and Borneo.

Habitat and ecology. On limestone.

Proposed IUCN conservation assessment. Least Concern (LC). This species has been collected at several sites over a wide area and there are no major threats.

Additional specimens examined. InDonesia. W Sumatra: Near Mount Sigirik within Bukit Sebelah nature reserve, 700 m, 15 v 1983 (fl), Y. Laumonier 4312 (L); Pajakumbuh (Payakumbuh), W coast, Region near Halaban, 800 m, 29 i 1958 (fr), W. Meijer 7554; near Pajakumbuh, Timur Pjk., G. Kapur Gadut, limestone hill [0¹0'S 100³0'E], 14 iv 1956 (fr), Ichlas Dj 112 (L).

Malaysia. Batu Bayan, 30 vii 1962 (fl), UNESCO Limestone Exp. 154 (L). Kelantan: Gua

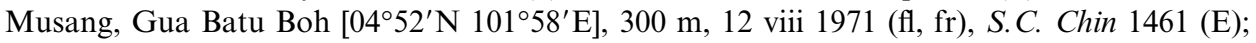
ibid., 22 xi 1971 (fl), Cult. in E 146 (E); Gua Musang [0453’ N 10158'E], 14 viii 1970 (fl, fr), B.C. Stone 9517 (L). Pahang: Gua Tipus, 17 x 1927, M.R. Henderson 19459b (K). Sarawak:

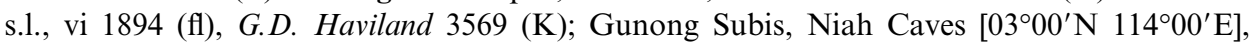
133 m, 6 vi 1962 (fr, fl), J.A.R. Anderson S16045 (E, SAR); Niah Caves, limestone, 6 vi 1962

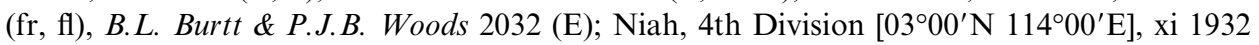
(fr, fl), P.M. Synge S589 (A, K, L).

Forbes (1882) cited no specimens in the protologue but mentioned 'I found this singularly beautiful and graceful plant in full flower in November 1881, first near the village of Napal Litjin, 580 feet above the sea; but in profusion on the large disrupted calcareous blocks near the summit of the peak of Karangnata, in company with magnificent spike-bearing Coelogynes and pink-fruited Melastomaceae'. We found the Forbes collection in BM, K and L, bearing the label 'Sumatra, 3130, H.O.Forbes: 1880'. We believe that these are the original material of Forbes' species.

It is not easy to define this species and there is a degree of variation amongst the specimens cited. Most of the collections from Peninsular Malaysia have leaves in whorls of 3, while those from Borneo (Sarawak), recently described as Paraboea culminicola but here treated in synonymy, have leaves in whorls of 4 . They also differ slightly in leaf shape and indumentum. The type was collected from Sumatra. Two isotypes $(\mathrm{K}, \mathrm{L})$ have leaves in whorls of 3 whilst the holotype (BM), with two individuals, has one with leaves in whorls of 3 and the other with leaves in whorls of 
4. Thus, there is no hard and fast geographical basis to this variation and the other slight variations do not merit specific delimitation.

This species is close to Paraboea verticillata and P. havilandii. Paraboea verticillata can be recognised by its delicate whitish indumentum on the lower leaf surface, and the last species may be defined by its very narrowly \pm obovate-oblong leaves.

84. Paraboea umbellata (Drake) B.L.Burtt, Notes Roy. Bot. Gard. Edinburgh 41: 440 (1984). - Boea umbellata Drake, Bull. Soc. Philom. Paris, ser. 8, 2: 129 (1890). - Paraboea rufescens var. umbellata (Drake) K.Y.Pan in Wang et al., Fl. Reipubl. Popularis Sin. 69: 467 (1990). - Type: Vietnam, Tonkin (Ha Noi), Cho-bo [21 $\left.02^{\prime} \mathrm{N} 105^{\circ} 50^{\prime} \mathrm{E}\right], 18$ x 1888 (fr), Balansa 4313 (lecto P, designated by Burtt (1984: 440); photo E).

Perennial rosulate herb with a stem extending up to $20 \mathrm{~cm}$ long when in flower, internodes then c.5-8 cm long. Leaves opposite, petiolate; petiole 5-10 cm long, indumentum the same as that on the lower leaf surface; blades ovate or elliptic, $8-20 \times$ $5-10 \mathrm{~cm}$ for mature vegetative leaves but much smaller for the leaves that subtend flowering cymes, 2-3 times as long as wide, apex obtuse, base cuneate, margin serrate or serrulate, upper surface densely pubescent, lower surface with a yellowish to brownish matted indumentum; veins obscure above, raised beneath, lateral veins c.610 pairs, tertiary venation reticulate. Inflorescence subterminal, cymose on an extended stem; cymes often 2 or 4 from the uppermost axils below the apical bud, generally shorter than the mature vegetative leaves (including the petiole), primary and secondary branches of the cyme hardly developed and so appearing umbellate (or capitate in bud), many-flowered, with a matted indumentum on peduncles, bracts, pedicels and calyx when young, this more or less shedding off when older; peduncle usually of similar length to the petiole of the mature vegetative leaves, with two large \pm rounded bracts embracing the flower buds when young; pedicels up to $10 \mathrm{~mm}$ long, bracts indistinct. Calyx c. $3.5 \mathrm{~mm}$ long, 5-lobed to the base, lobes narrowly oblong, c. 3 $\times 0.7 \mathrm{~mm}$, apex truncate or slightly sinuolate, spreading outward. Corolla c. $10 \mathrm{~mm}$ long, $10 \mathrm{~mm}$ across; tube c. $8 \mathrm{~mm}$ long, limb barely 2-lipped; 5 lobes of similar shape and size, rounded, c. $3 \times 4 \mathrm{~mm}$. Anthers transversely ellipsoid, c. $1.2 \times 3.5 \mathrm{~mm}$, coherent with each other at the upper end, apertured at the upper end, apex turned towards the gynoecium, basifixed; filaments inserted at the extreme base of the corolla with a free part c. $3 \mathrm{~mm}$ long, with tiny lanate hairs; staminodes 2 , c. $1 \mathrm{~mm}$ long to almost absent. Gynoecium c. $10 \mathrm{~mm}$ long, $1.5 \mathrm{~mm}$ wide at the base of the ovary; style curved towards the anthers; stigma oblique, seemingly scabrous. Fruit a linear capsule, relatively long, up to $5 \mathrm{~cm}$ long, glabrous, spirally twisted. Seeds ellipsoid, c. $0.7 \times 0.3 \mathrm{~mm}$.

Distribution. Northern Vietnam and southern China (southwest Guangxi).

Habitat and ecology. On limestone.

Proposed IUCN conservation assessment. Least Concern (LC). This species has been collected at many sites over a wide area and there are no major threats. 
Additional specimens examined. ChinA. Guangxi: 5 vii 1957 (fr, fl), S.C. Chen 13048 (IBSC); 9 viii 1953 (fl, fr), Guangxi-Team 3303 (PE); Lungchow [Long2zhoul] [22 $25^{\prime} \mathrm{N} 106^{\circ} 50^{\prime} \mathrm{E}$ ], 1901 (fl), A. Henry 691 (K, NY); [cultivated at Bailey Garden from Henry 691, the Morse 691 below may be the same collection], 1901 (fl), H.B. Morse 691 (US); Daxin [Da4xin1] [22 $52^{\prime} \mathrm{N}$ 107¹0'E], vi-vi 1981 (fr), H.N. Qin 425 (PE).

Vietnam. Cao Bang: Hang Pac Bo, near Ho Chi Minh Memorial, 22 $58^{\prime} 37^{\prime \prime} \mathrm{N} 106^{\circ} 03^{\prime} 26^{\prime \prime} \mathrm{E}$, $390 \mathrm{~m}, 1$ xi 2002 (ster), grown on at RBGE as accession no. 20022504, vouchered as D.J. Middleton

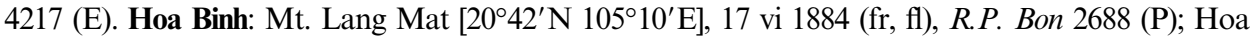

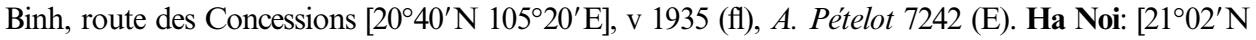

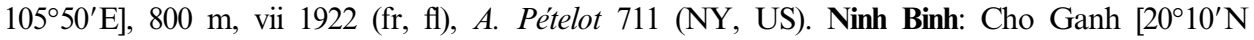
$105^{\circ} 57^{\prime} \mathrm{E}$ ], vii 1922 (fl, fr), A. Pételot 711N (P); Cho Ganh, calcaires [20¹0' N $105^{\circ} 57^{\prime} \mathrm{E}$ ], vii 1922 (fl),

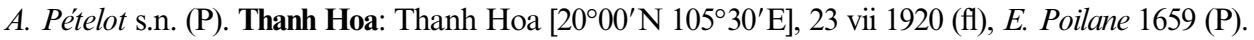

Pan (in Wang et al., 1990) reduced this specific name to a variety of Paraboea rufescens (var. umbellata) and argued that $P$. umbellata has intermediate forms with P. rufescens var. rufescens in southwest Guangxi (China). From there southward the plants gradually have larger leaves and longer stems. Our study has maintained Paraboea umbellata and P. rufescens as distinct species with clear differences in their inflorescence structure. Paraboea umbellata has an extended flowering stem from which the inflorescence is subterminal. This means the plant is monocarpic because the terminal bud in such a flowering branch will cease growing after a flowering season. In Paraboea rufescens the plants have axillary cymes from basal leaves and the terminal bud will continue to grow after the flowering season. Unlike the relationship between Paraboea rufescens var. rufescens and var. tomentosa, the differences between $P$. rufescens and $P$. umbellata are not merely an elongated stem vs. a short stem, but rather a completely different inflorescence structure. We have not found any intermediate forms that produce both patterns on the same plant in either Paraboea rufescens or P. umbellata. This is also the case throughout the genus. Thus, we resurrect Paraboea umbellata.

Chun (Chen2 Huan4 Yong2) identified S.P. Ko 55128 as a new species. However, it seems that he never published it. The collection is referable to Paraboea umbellata.

85. Paraboea uniflora Z.R.Xu \& B.L.Burtt, Edinburgh J. Bot. 48: 15 (1991). - Type: Thailand, Songkhla, Sadao District $\left[06^{\circ} 55^{\prime} \mathrm{N} 100^{\circ} 24^{\prime} \mathrm{E}\right]$, Kao Roop Chang, Padang Besar, on open, rugged summit of a limestone peak, 11 vii 1986 (fr, fl fragment), J.F. Maxwell 86-451 (holo PSU; iso A, L).

Subshrub with branched woody stem; stem with a tawny matted indumentum when young (1-2 years), glabrous when older (3 years or more), $>1 \mathrm{~cm}$ in diameter; internodes quite short. Leaves congested at the apex of the stem, sessile, elliptic, 1.5$2.5 \times 0.8-1.5 \mathrm{~cm}$, apex acute or obtuse, base angustate or attenuate to the base, margin entire, lower surface with a white matted indumentum, upper surface with a looser and thinner covering of strigulose pubescence; veins smooth above, raised beneath, lateral veins c.5 pairs, forming an acute angle, $<45^{\circ}$ with the midrib, tertiary venation invisible. Inflorescence axillary, single-flowered; pedicel $1.5-2.5 \mathrm{~cm}$ 
long, with a white matted indumentum. Calyx pale green, c. $4.5 \mathrm{~mm}$ long, 5-lobed, lobes narrowly oblong, 6-10 times as long as wide, with a white matted indumentum outside, glabrous inside. Corolla unknown, pale lilac to blue (fide Maxwell). Anthers yellow (fide Maxwell). Ovary ovoid, $3.5 \times 1 \mathrm{~mm}$, glabrous; style $4.5 \mathrm{~mm}$ long; stigma capitate, a little larger than style. Fruit a narrow-ovoid capsule, 1-2.5 cm long, glabrous, spirally twisted. Seeds not seen.

Distribution. Thailand: Songkhla. Known only from the type.

Habitat and ecology. On limestone.

Proposed IUCN conservation assessment. Critically Endangered (CR B1ab(ii,iii,v)) see conservation assessment section in introduction. This species was also included in Pooma (2005) as threatened in Thailand.

This species is unique in the genus with its single-flowered inflorescence. This may be an extreme reduction of a normal cyme. The habit seems close to Paraboea lanata but the veins on the leaves are more prominent.

86. Paraboea variopila Z.R.Xu \& B.L.Burtt, Edinburgh J. Bot. 48 : 15 (1991). - Type: Thailand, Surat Thanee [Surat Thani] Province, common on stone in evergreen forest, 12 viii 1975 (fl, fr), D. Praphat 8 (holo E; iso BKF, C, L).

Perennial caulescent herb; stem c. $30-50 \mathrm{~cm}$ tall, $7 \mathrm{~mm}$ in diameter; internodes 1.2 $7 \mathrm{~cm}$ long, with a greyish brown matted indumentum and later glabrescent. Leaves opposite, sessile, obovate, (5-)11-17 $\times(2-) 3-5.5 \mathrm{~cm}$, apex obtuse, blade narrowed and then slightly expanded just above base, margin sparsely serrulate or entire, upper surface densely pubescent, lower surface with a greyish-orange matted indumentum; veins smooth above, raised beneath, lateral veins 5-11 pairs, tertiary venation obscure. Inflorescence axillary near the apical bud (or subterminal), cymose, 10-17 $\times$ 3-15 cm, many-flowered, with dense dark brown glandular hairs throughout; the two primary branches of the cyme not dichasially branching again, but monochasially extending to a long racemose branch without a bifurcation; peduncle (2-)4.5-9 cm long, c. $2 \mathrm{~mm}$ wide, peduncle bracts sepal-like; pedicel short, c.1-2 mm long, pedicel bracts very tiny, c.1/5 size of a sepal or invisible. Calyx (2-) $4.5 \mathrm{~mm}$ long, 5-lobed, lobes linear, c.10 times as long as wide, glabrous inside, with dark brown glandular hairs outside. Corolla pinkish-white, c. $6 \mathrm{~mm}$ long, $8 \mathrm{~mm}$ across, with dark brown glandular hairs outside, glabrous inside; tube $2 \mathrm{~mm}$ long, limb 2-lipped; upper lip 2-lobed, lobes ovate, $3.5 \times 2.2 \mathrm{~mm}$, lower lip 3-lobed, two lateral lobes similar in size and shape to the upper lobes, middle one slightly obovate or elliptic, similar in size to lateral lobes. Anthers transversely ellipsoid, $2 \times 3 \mathrm{~mm}$, glabrous, coherent with each other at the apex, opening in the centre of the anther locules, apex turned towards the gynoecium, basifixed; filaments c. $1.5 \mathrm{~mm}$ long. Gynoecium c.6 mm long; ovary c. $1.2 \mathrm{~mm}$ wide, with glandular hairs; stigma enlarged, capitate. Fruit narrow oblong or linear, $1.5-2.7 \mathrm{~cm}$ long, c. $1.7 \mathrm{~mm}$ in diameter, 
with dark brown glandular hairs, slightly twisted. Seeds narrow-ellipsoid, c.0.5 $\times$ $0.1 \mathrm{~mm}$.

Distribution. Thailand.

Habitat and ecology. On limestone.

Proposed IUCN conservation assessment. Least Concern (LC). Although this species is only known from two collections at least one of these is from the well-protected and extensive limestone area of Khao Sok National Park. This species was, however, included in Pooma (2005) as threatened in Thailand.

Additional specimen examined. Thailand. Surat Thani: Pa Nom district, Khao Sok National Park [09 $\left.10^{\prime} \mathrm{N} 98^{\circ} 42^{\prime} \mathrm{E}\right]$, limestone hill, 100-200 m, 12 xii 1979 (ster), T. Shimizu et al. T-27070 (BKF, L).

This species is similar to Paraboea trachyphylla and P. acutifolia with which it shares the same inflorescence structure. However, the indumentum on the ovary and the capsule separates the three species: Paraboea variopila having dark brown glandular hairs, $P$. acutifolia possessing a matted indumentum, and $P$. trachyphylla without an indumentum.

87. Paraboea velutina (W.T.Wang \& C.Z.Gao) B.L.Burtt, Notes Roy. Bot. Gard. Edinburgh 41: 440 (1984). - Buxiphyllum velutinum W.T.Wang \& C.Z.Gao, Bull. Bot. Res., Harbin 1: 37 (1981). - Type: China, Kwangsi (Guangxi), Fengshan [2430'N 10702'E], 13 i 1978 (fl), C.Z. Gao \& A.J. Zhung 30491 (holo GXMI n.v.; iso PE). Fig. 51.

Small plant with a short woody stem. Leaves numerous, alternately congested at top of the stem; petiole terete, very short, c.5 mm long, with a greyish matted indumentum; blades obovate, $1.5-2.5 \times 0.7-1 \mathrm{~cm}, 1.5-3$ times as long as wide, apex rounded, base attenuate or widely cuneate, margin entire, upper surface with some arachnoid indumentum when young and glabrescent when mature, lower surface with a greyish matted indumentum; veins visible on both surfaces, slightly depressed above, raised beneath, lateral veins c.5 pairs, joining each other near the margin and forming a distinct intramarginal vein, tertiary venation visible above, conspicuously reticulate beneath. Inflorescence axillary, cymose, with a few flowers or only one flower in rare cases, similar in length to the leaves, c. $2.5 \mathrm{~cm}$ long, \pm hairy; peduncle slender, c. $2-2.5 \mathrm{~cm}$ long, primary bracts sepal-like; pedicel 4-5 mm long, with a distinct ferrugineous pubescence. Calyx c.1 mm long, 5-lobed to the base, lobes narrowly ovate or oblong-ovate, $1 \times 0.3 \mathrm{~mm}$, obtuse at apex, \pm farinose inside. Corolla white, $5 \mathrm{~mm}$ long, c. $7 \mathrm{~mm}$ across, \pm minutely pubescent; tube $3.5 \mathrm{~mm}$ long, limb 2-lipped; upper lip with 2 lobes, rounded, c. $1.5 \times 1 \mathrm{~mm}$, lower lip $7 \mathrm{~mm}$ wide with 3 lobes, rounded or widely ovate, c. $1.5 \times 2.3 \mathrm{~mm}$. Anthers transversely ellipsoid, c. $0.5 \times 1.5 \mathrm{~mm}$, dehiscing in the centre, coherent with each other, \pm dorsifixed; filaments \pm curved, c. $1 \mathrm{~mm}$ long; visible staminodes 2, c. $0.5 \mathrm{~mm}$ 


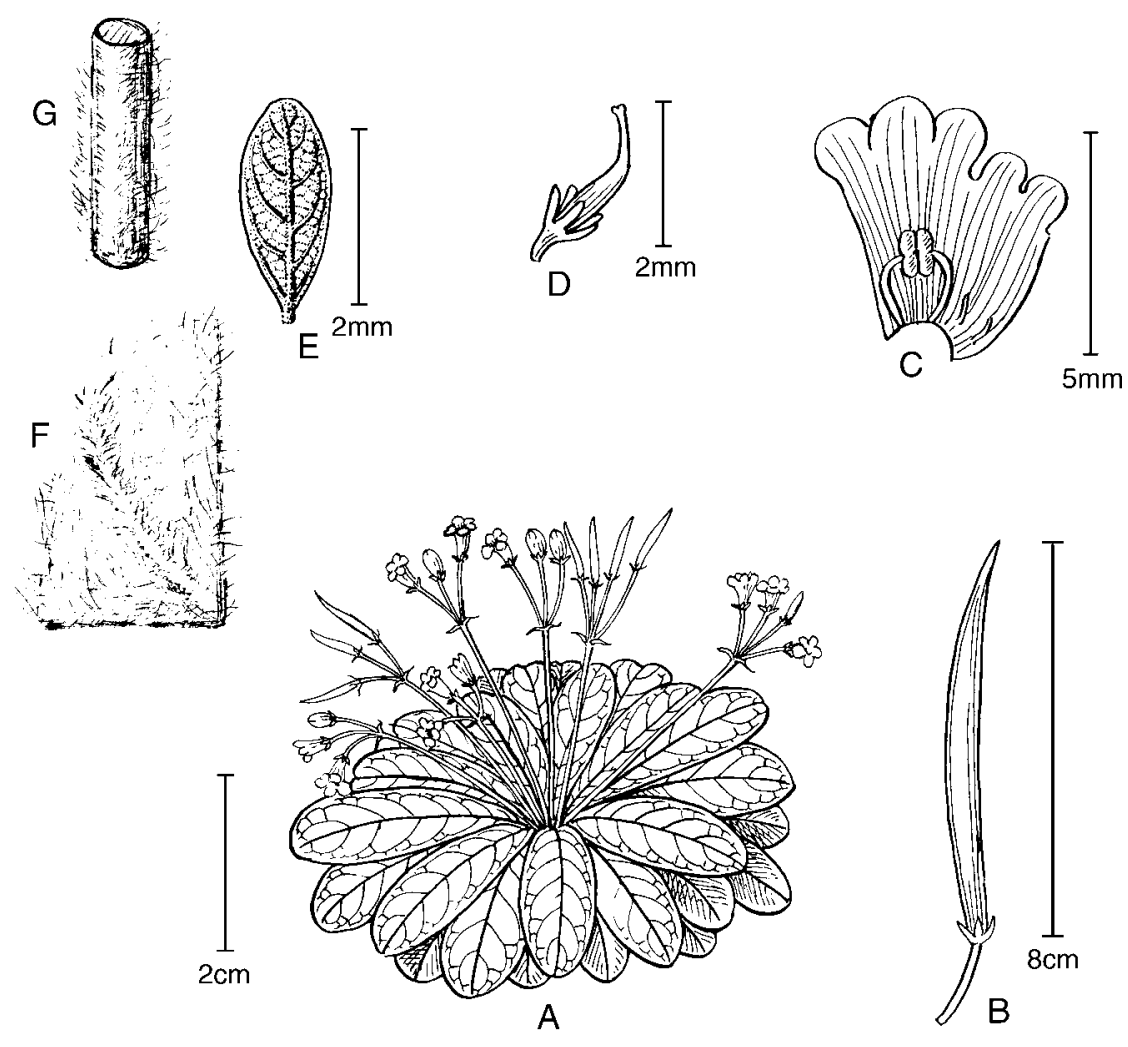

FIG. 51. Paraboea velutina (W.T.Wang \& C.Z.Gao) B.L.Burtt. A, habit; B, fruit; C, corolla opened out; D, pistil; E, leaf; F, indumentum on leaf; G, section of peduncle.

long. Gynoecium c. $3.5 \mathrm{~mm}$ long, \pm with sessile glands; ovary c. $1.5 \times 0.6 \mathrm{~mm}$; style distinct from ovary, c. $2 \times 0.1 \mathrm{~mm}$; stigma slightly larger than style. Fruit a nontwisted capsule, $0.8 \mathrm{~cm}$ long, 4-valved. Seeds not seen.

Distribution. China: Guangxi. Known only from the type.

Habitat and ecology. Reported from the cliff beside a limestone cave.

Proposed IUCN conservation assessment. Critically Endangered (CR B1ab(ii,iii,v)) see conservation assessment section in introduction.

This species is similar to Paraboea filipes in the appearance of the leaves and inflorescence. The difference lies in their habits and in the venation (see the key). This species has a woody stem and the venation on the lower leaf surface is conspicuously reticulate, while Paraboea filipes is truly rosulate and possesses no conspicuous venation.

88. Paraboea verticillata (Ridl.) B.L.Burtt, Bot. J. Linn. Soc. 85: 25 (1982); Burtt, Notes Roy. Bot. Gard. Edinburgh 41: 440 (1984). - Boea verticillata Ridl., J. Linn. 
Soc., Bot. 32: 519 (1896). - Type: Malay Peninsula, Selangor Gua Batu, limestone rocks at Kuala Lumpur, vii 1897 (fr, fl), Kelsall s.n. (lecto K, designated here; iso BM). Fig. 52.

Perennial caulescent herb, up to $60 \mathrm{~cm}$ tall; stem woody, c. $5 \mathrm{~mm}$ in diameter, basal internodes $0.5-2.5 \mathrm{~cm}$ long, upper internodes up to $11 \mathrm{~cm}$ long, with a white matted indumentum when young, glabrescent when old. Leaves in whorls of 3, rarely of 4, short-petiolate; petiole up to $2.5 \mathrm{~cm}$ long, upper leaves appearing sessile; blades elliptic or narrowly so, $4.5-13 \times 1.5-3.5 \mathrm{~cm}, 2.5-4$ times as long as wide, apex acute, base angustate, margin entire, upper surface with some white arachnoid covering, lower surface with a white matted indumentum; veins smooth above, raised beneath, lateral veins dense, 7-23 pairs, c. $5 \mathrm{~mm}$ apart, tertiary venation invisible. Inflorescence terminal, paniculate, with a white matted indumentum throughout except on the flower; flowering stem c.20-45 cm long, the lowest internodes c.(2-)6-12 cm long, floral leaves gradually reducing in size from caulescent leaves upward; 3 (rarely 4) cymes from each node; cymes short, normally $<10 \mathrm{~cm}$ long, peduncle bracts narrow-ovate, c. $5 \mathrm{~mm}$ long, pedicel bracts sepal-like; pedicels $<10 \mathrm{~mm}$ long. Calyx c.3 mm long, 5-lobed, lobes narrowovate, outside with a whitish matted indumentum, inside glabrous. Corolla blue, purple or violet; tube c. $2 \mathrm{~mm}$ long, limb 2-lipped; upper lip $5 \mathrm{~mm}$ long, 2-lobed, lobes wide-ovate, $3.5 \times 4 \mathrm{~mm}$, lower lip $8 \mathrm{~mm}$ long, 3-lobed, lateral lobes wideovate, $3 \times 4 \mathrm{~mm}$, middle one obovate or rounded, c. $3 \times 3.5 \mathrm{~mm}$. Anthers transversely ellipsoid, c. $2 \times 4 \mathrm{~mm}$, coherent with each other at the apex and the base, opening in the centre of the anther locules, apex turned towards the gynoecium, dorsifixed; filaments inserted at the corolla base with a free part c. $3 \mathrm{~mm}$ long, seemingly ciliate in the middle, crenulate on the margin. Ovary ovoid, c. $1.5 \times$ $1.2 \mathrm{~mm}$, distinguishable from the style; style $5 \mathrm{~mm}$ long, narrower than the ovary; stigma capitate, little larger than style. Fruit a linear capsule, c.1-2 cm long, $2 \mathrm{~mm}$ in diameter, glabrous, spirally twisted. Seeds ellipsoid, $0.5 \times 0.15 \mathrm{~mm}$.

Distribution. Peninsular Malaysia.

Habitat and ecology. On limestone.

Proposed IUCN conservation assessment. Least Concern (LC). This species has been collected at several sites over a wide area and there are no major threats.

Additional specimens examined. Malaysia. Gua Batu, ix 1898 (fl, fr), H.N. Ridley 8551 (BM, K). Selangor: Near Kuala Lumpur, Bukit Takun, Templer Park [03 $\left.16^{\prime} \mathrm{N} 101^{\circ} 40^{\prime} \mathrm{E}\right], 400 \mathrm{~m}$, 29 vi 1975 (fr), M.M.J. van Balgooy 2701 (E, L); Gua Batu [ = Batu Cave], 200 m, 27 vii 1971 (fl), S.C. Chin 1252 (K, KLU, L); Bukit Takun, Kanching F.R. [0320' N 101 $\left.{ }^{\circ} 35^{\prime} \mathrm{E}\right], 500 \mathrm{~m}$,

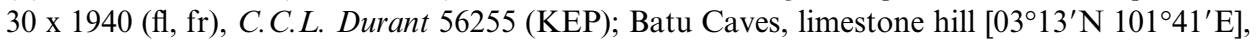
266 m, 14 x 1966 (fl, fr), FRI 1628 (A, K, L); Bukit Takun, Kanching, Selangor, on limestone

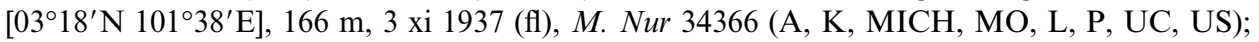
Ulu Selangor, Bukit Takun, Kanching F.R., Kanching, 500-600 m, 5 xi 1940 (fl), S. Reid KEP51677 (KEP); Kanching, 16 iii 1935 (fl), S. Reid KEP37429 (KEP); Bukit Takun, 8 v 1939 


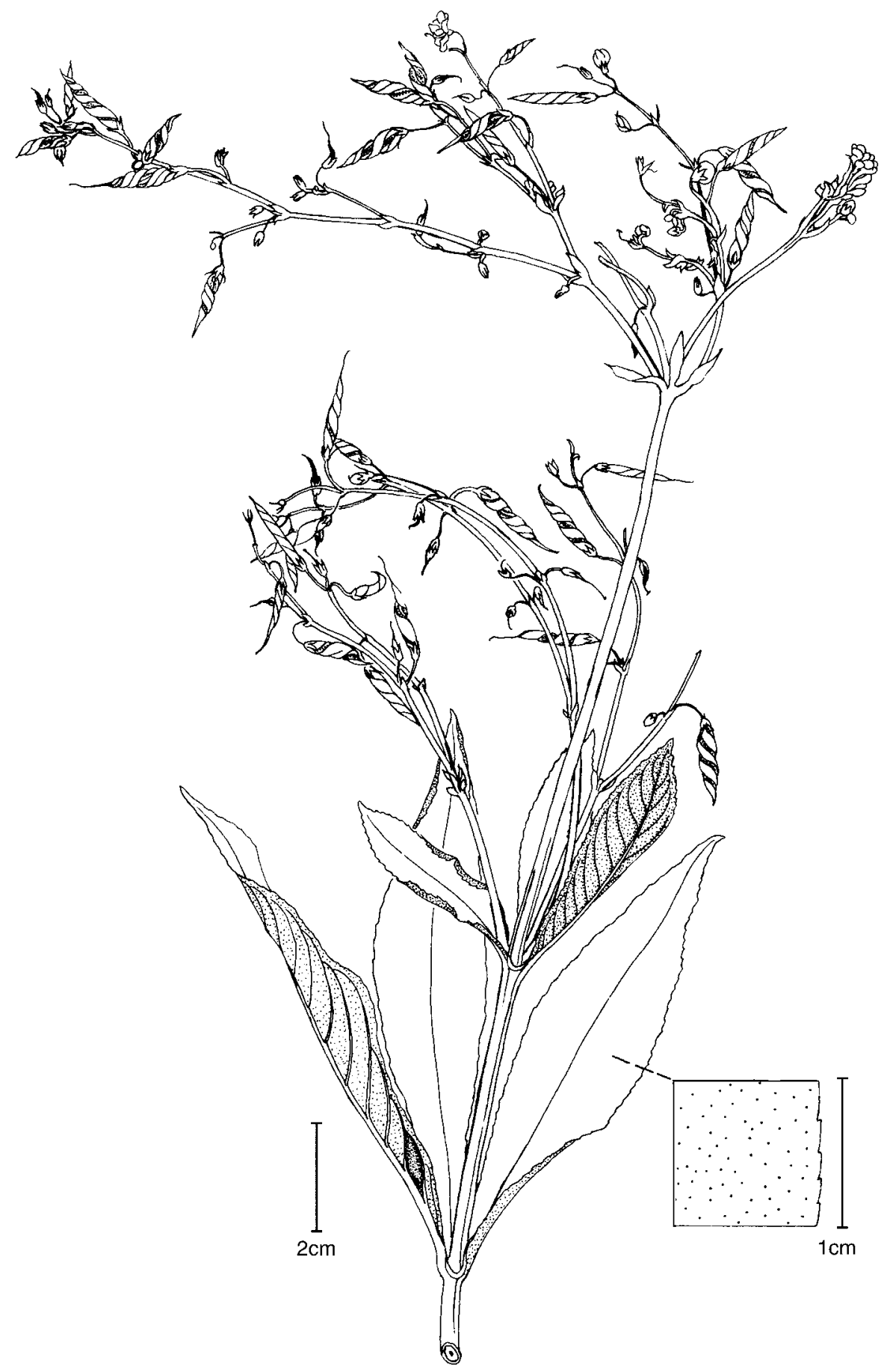

FIG. 52. Paraboea verticillata (Ridl.) B.L.Burtt. 
(fr), C.F. Symington KEP39596 (K); Batu Caves, 233 m, 22 xi 1959 (fl), J. W. Smith KEP79244 (KEP); Bukit Takun, Kanching, 17 ix 1940 (fl, fr), Sow \& Tachun KEP35093 (KEP). Kedah:

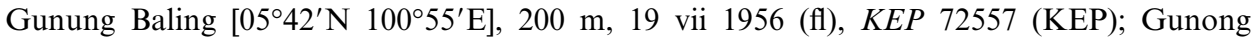
Baling, 333 m, 8 v 1941 (fl), J.C. Nauen 38021 (A, K, KEP).

This species is similar to Paraboea treubii. Paraboea verticillata can be distinguished by the smaller leaves on which a whitish arachnoid covering persists (vs. no persisting arachnoid covering) on the upper surface and a silvery (vs. tawny or whitish) matted indumentum occurs on the lower surface.

89. Paraboea vulpina Ridl., J. Straits Branch Roy. Asiat. Soc. 44: 69 (1905); Burtt, Notes Roy. Bot. Gard. Edinburgh 41: 441 (1984). - Type: Peninsular Malaysia, Hot Springs, Ipoh, Kinta [0331'N 101 $\left.12^{\prime} \mathrm{E}\right]$, xii 1896 (fl), Curtis 3132 (lecto K, designated by Burtt (1984: 441); iso SING). Fig. 53.

Perennial herb, with or without a very short stem. Leaves (oppositely?) congested in a rosette with a visible petiole; petiole c. $2-8 \mathrm{~cm}$ long, with ferrugineous multibranched hairs; blades ovate, 6-10 $\times 5-7 \mathrm{~cm}, 1-1.5$ times as long as wide, apex obtuse or rounded, base truncate or shallowly cordate, margin regularly crenate, with a sparse long pubescence above and ferrugineous multi-branched hairs beneath; veins slightly depressed above, raised beneath, lateral veins 6-8 pairs, tertiary venation reticulate. Inflorescence axillary, cymose, longer than leaves, c.15-35 cm long, many-flowered, very lax, more or less with multi-branched hairs except on flowers which are glabrescent; peduncle 14-20 cm long, with 2 linear bracts up to $1 \mathrm{~cm}$ long; primary branches up to $9 \mathrm{~cm}$ long; pedicels 5-15 mm long, slender, with sepal-like bracts. Calyx campanulate, 5-lobed to the base; lobes narrowly ovate, 1.5 $\times 0.5 \mathrm{~mm}$, obtuse at apex, glabrous outside, with minute sessile glands inside. Corolla purple in cultivation; $8 \mathrm{~mm}$ across, $5 \mathrm{~mm}$ long, glabrous outside, with minute sessile glands inside; tube short, 2-2.5 mm long, limb 2-lipped; upper lip 2-lobed, lobes widely ovate, $3.5 \times 3 \mathrm{~mm}$, lower lip 3-lobed, middle lobe smaller, c. $3 \times 3 \mathrm{~mm}$, lateral lobes $7 \times 8 \mathrm{~mm}$. Stamens 2 ; anthers transversely ellipsoid, $1.5-1.7 \times 2.5 \mathrm{~mm}$, opening in the centre of the anther locules, coherent with each other, dorsifixed by the filaments, apex \pm pointing to gynoecium; filaments short, inserted c. $2 \mathrm{~mm}$ from the corolla base. Gynoecium narrowly ovoid, c. $6.5 \mathrm{~mm}$ long; ovary $0.7 \mathrm{~mm}$ wide, smoothly intergrading into style, but style distinct, $0.2 \mathrm{~mm}$ wide; stigma slightly enlarged. Fruit a cylindrical capsule, not spirally twisted, c. $2.2 \mathrm{~cm}$ long, c. $2 \mathrm{~mm}$ in diameter, glabrous. Seeds not seen.

Distribution. Peninsular Malaysia and Peninsular Thailand.

Habitat and ecology. Recorded from limestone.

Proposed IUCN conservation assessment. Least Concern (LC). Although this species is only known from few collections it is found over a large area and several of the known sites are in protected areas, and there are no major threats. 


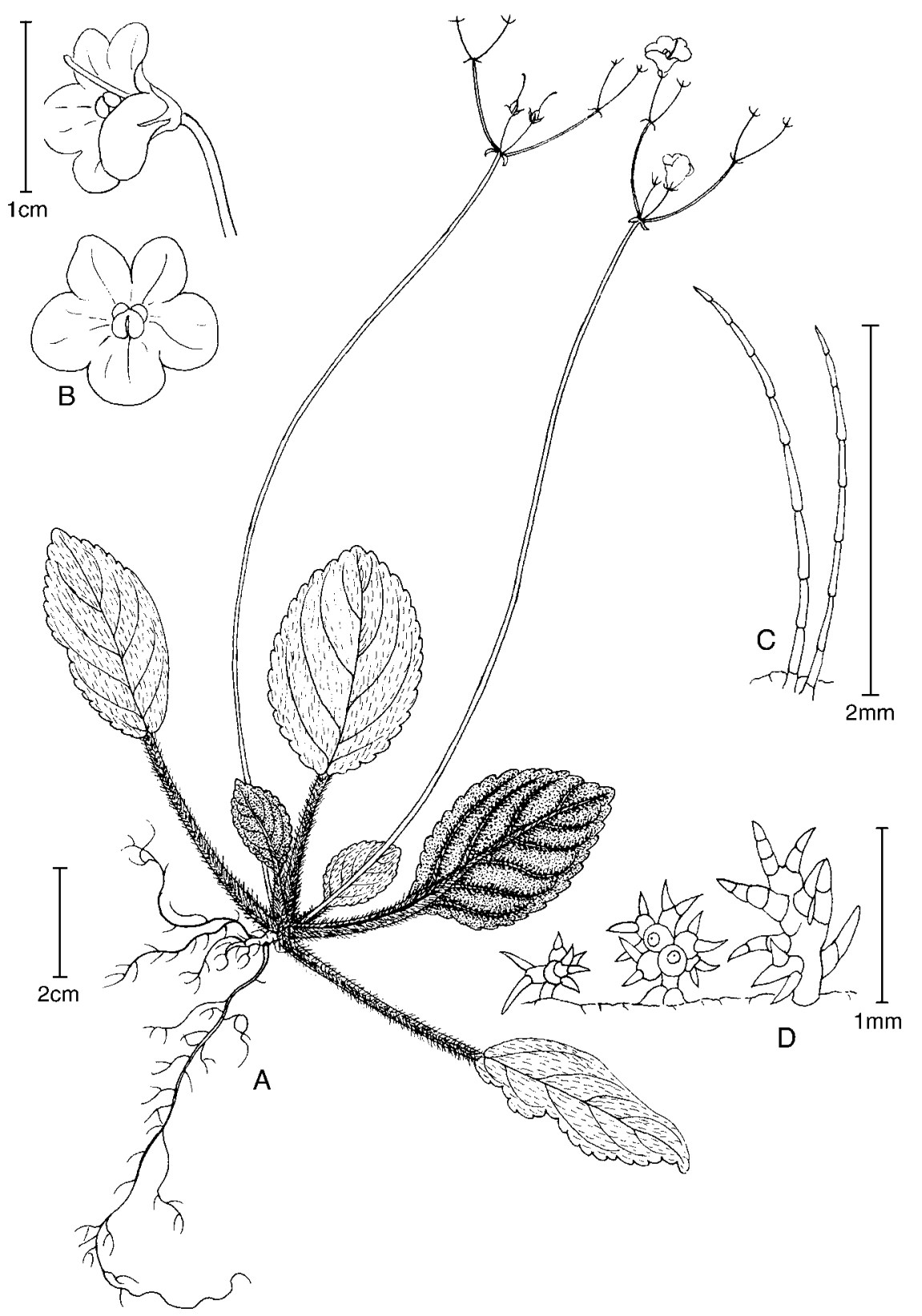

FIG. 53. Paraboea vulpina Ridl. A, habit; B, flower; C, hairs on upper leaf surface; D, hairs on lower leaf surface.

Additional specimens examined. Malaysia. Perak: Ipoh Ayer Hangat, c.400 ft (120 m), on limestone $\left[04^{\circ} 35^{\prime} \mathrm{N} 101^{\circ} 06^{\prime} \mathrm{E}\right], 166 \mathrm{~m}, 21$ iv 1962 (fl), B.L. Burtt \& P.J.B. Woods 1688 (E); [collection from c. $04^{\circ} 00^{\prime} \mathrm{N} 102^{\circ} 00^{\prime} \mathrm{E}$ ], 1962 (fl), Cult. in E 3980 (E). 
Thailand. Trang: Nam Tai, $20 \mathrm{~km}$ N of Trang, limestone rock [0742' N 9947'E], 11 x 1970 (fr), Charoenphol, Larsen \& Warncke 3642 (AAU). Krabi: Tam Soea, $10 \mathrm{~km} \mathrm{~N}$ of Krabi,

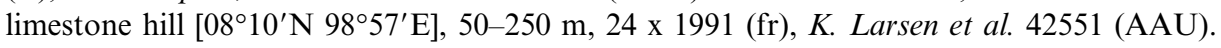

This species may be related to Paraboea laxa with which it shares similar large and spreading cymes. However, Paraboea vulpina has branched hairs while P. laxa does not. This species may also be related to Paraboea tarutaoensis with which it shares the same multi-branched hairs. The latter species can be recognised by its fewflowered inflorescence. Another species, Paraboea brunnescens, which has both branched hairs and a matted indumentum, is also comparable to the above species, but the latter species has a twisted capsule. The similarity between species differing only in whether the fruit is twisted or not was used by Burtt (1984) as evidence to challenge the phylogenetic value of the carpology between Paraboea and Boea. Two collections, however, may blur the difference between Paraboea vulpina and P. laxa (and maybe also P. tarutaoensis and P. brunnescens). Kurzweil HK783 (WU), collected from Peninsular Thailand (Satun Province), has both a long pubescence and multi-branched hairs, and Kiah 24376 (BM, K, SING), collected from northern Thailand (Kamphaeng Phet), has petiolate leaves but no multi-branched hairs. In this treatment, Kurzweil HK783 (WU) is recognised as Paraboea tarutaoensis, Kiah 24376 as P. laxa, and Charoenphol, Larsen \& Warncke 3642 (AAU) is treated as $P$. vulpina. Paraboea vulpina can be distinguished from P. laxa and P. tarutaoensis by the lack of a matted indumentum on the lower leaf surface.

Burtt (1984) noted that Charoenphol, Larsen \& Warncke 3642 (AAU) may represent an allied but undescribed species to Paraboea vulpina, differing by: leaves with a dense short pubescence above (rather than sparse long hairs), and multibranched hairs with a long stalk and a whorl of longish branches at top (rather than with a short or absent stalk).

\section{EXCLUDED TAXA}

Paraboea alternifolia (C.B.Clarke) B.L.Burtt, Notes Roy. Bot. Gard. Edinburgh 24: 46 (1962). = Henckelia alternifolia (C.B.Clarke) A.Weber, Beitr. Biol. Pflanzen 70: 339 (1998 ['1997’]).

Paraboea bettiana M.R.Hend., Gard. Bull. Straits Settl. 7: 116 (1933). = Emarhendia bettiana (M.R.Hend.) Kiew, A.Weber \& B.L.Burtt, Beitr. Biol. Pflanzen 70: 398 (1998 ['1997’]).

Paraboea caerulea Ridl., J. Straits Branch Roy. Asiat. Soc. 44: 66 (1905). = Henckelia densifolia (Ridl.) A.Weber, Beitr. Biol. Pflanzen 70: 343 (1998 ['1997’]).

Paraboea campanulata Ridl., J. Straits Branch Roy. Asiat. Soc. 44: 65 (1905). = probably Henckelia hirta (Ridl.) A.Weber, Beitr. Biol. Pflanzen 70: 346 (1998 ['1997’]).

Paraboea cordata (A.DC.) Ridl., J. Straits Branch Roy. Asiat. Soc. $44: 64$ (1905). = Didymocarpus cordatus A.DC., Prodr. 9: 265 (1845). 
Paraboea densifolia (Ridl.) M.R.Hend., Gard. Bull. Straits Settl. 5: 79 (1930). = Henckelia densifolia (Ridl.) A.Weber, Beitr. Biol. Pflanzen 70: 343 (1998 ['1997’]).

Paraboea filicifolia (Ridl.) Ridl., Fl. Malay Penins. 2: 530 (1923). = Henckelia salicina (Ridl.) A.Weber, Beitr. Biol. Pflanzen 70: 355 (1998 ['1997’]).

Paraboea floribunda M.R.Hend., Gard. Bull. Straits Settl. 7: 117 (1933). = Henckelia floribunda (M.R.Hend.) A.Weber, Beitr. Biol. Pflanzen 70: 345 (1998 [‘1997’]).

Paraboea grandifolia Ridl., Fl. Malay Penins. 2: 531 (1923). = Henckelia tahanica (B.L.Burtt) A.Weber, Beitr. Biol. Pflanzen 70: 357 (1998 ['1997’]).

Paraboea holttumii M.R.Hend., Gard. Bull. Singapore 4: 54 (1927). = Henckelia holttumii (M.R.Hend.) A.Weber, Beitr. Biol. Pflanzen 70: 346 (1998 ['1997’]).

Paraboea leucocodon Ridl., J. Fed. Malay States Mus. 6: 167 (1915). = Henckelia leucocodon (Ridl.) A.Weber, Beitr. Biol. Pflanzen 70: 348 (1998 ['1997’]).

Paraboea nagalandiana Deb \& Dutta, J. Bombay Nat. Hist. Soc. 85: 168 (1988). = Staurogyne sp.

Paraboea pubiflora Ridl., J. Fed. Malay States Mus. 4: 51 (1909). = Henckelia venusta (Ridl.) A.Weber, Beitr. Biol. Pflanzen 70: 358 (1998 ['1997’]).

Paraboea pyroliflora (Ridl.) Ridl., J. Straits Branch Roy. Asiat. Soc. 44 : 67 (1905). = Henckelia pyroliflora (Ridl.) A.Weber, Beitr. Biol. Pflanzen 70: 353 (1998 ['1997']).

Paraboea rubiginosa Ridl., J. Linn. Soc., Bot. 38: 319 (1908). = Henckelia rubiginosa (Ridl.) A.Weber, Beitr. Biol. Pflanzen 70: 355 (1998 ['1997’]).

Paraboea salicina (Ridl.) Ridl., Fl. Malay Penins. 2: 530 (1923). = Henckelia salicina (Ridl.) A.Weber, Beitr. Biol. Pflanzen 70: 355 (1998 ['1997’]).

Paraboea scortechinii Ridl., J. Straits Branch Roy. Asiat. Soc. 44: 65 (1905). = Henckelia scortechinii (Ridl.) A.Weber, Beitr. Biol. Pflanzen 70: 356 (1998 ['1997’]).

Paraboea tiumanica Ridl., Fl. Malay Penins. 2: 530 (1923). = Henckelia tiumanica (Ridl.) A.Weber, Beitr. Biol. Pflanzen 70: 357 (1998 ['1997’]).

\section{ACKNOWLEDGEMENTS}

The first author is extremely grateful to the Royal Botanic Garden Edinburgh and the Smithsonian Institution from which he received funding and facilities to carry out this study. The authors are grateful to all the herbaria listed in the citations of collections in this paper for loaning their material. The following are also gratefully acknowledged: Mr Qing Jian Xie did the line drawings; Ms Daan Yu (the first author's wife) databased most of the collections and typed a large part of the handwritten manuscript; Dr J. E. Vidal, Dr S. K. Yap, Prof. Halijah Ibrahim, Dr J. H. Chou, Dr Ben Tan and Dr J. F. Maxwell helped to check the locality names and their coordinates; Dr Craig Hilton-Taylor provided valuable advice on the application of the IUCN conservation assessments. Prof. Ruth Kiew and Dr Pramote Triboun are gratefully acknowledged for their critical comments on the manuscript, and Dr Mark Newman of the Editorial Board is acknowledged for checking that 
the reviewers' comments were appropriately acted upon given that the editor is a coauthor of the paper.

\section{REFERENCES}

Barnett, E. C. (1961). Contributions to the Flora of Thailand: LV. Kew Bull. 15: 249-259.

Burtt, B. L. (1941). Paraboea glabrisepala. Kew Bull. 1941: 21.

Burtt, B. L. (1948). A note on Paraboea. Kew Bull. 1948: 55-56.

BuRTt, B. L. (1954). Studies in the Gesneriaceae of the Old World: II - Types and lectotypes of certain genera and groups of lower rank. Notes Roy. Bot. Gard. Edinburgh 21: 193-208.

Burtt, B. L. (1971). Studies in the Gesneriaceae of the Old World: XXXIV - A miscellany from South Eastern Asia. Notes Roy. Bot. Gard. Edinburgh 31: 35-52.

BurtT, B. L. (1984). Studies in the Gesneriaceae of the Old World: XLVII - Revised generic concepts for Boea and its allies. Notes Roy. Bot. Gard. Edinburgh 41: 401-452.

Clarke, C. B. (1883). Cyrtandreae. In: de Candolle, A. \& de Candolle, C., Monographie Phanerogamarum 5: 1-303.

Clements, R., Sodhi, N. S., Schilthuizen, M. \& NG, P. K. L. (2006). Limestone karsts of Southeast Asia: imperiled arks of biodiversity. BioScience 56: 733-742.

Craib, W. G. (1916). Contributions to the Flora of Siam. Additamentum IX. Bull. Misc. Inform. Kew 1916: 259-269.

Forbes, H. O. (1882). On two new, and one wrongly referred, Cyrtandraceae. J. Linn. Soc., Bot. 19: 297-298.

Fritsch, K. (1894). Gesneriaceae. In: Engler, A. \& Prantl, K., Die Natürlichen Pflanzenfamilien 4(3B): 133-185. Leipzig: W. Engelmann.

IUCN (2001). IUCN Red List Categories and Criteria, Version 3.1. Gland and Cambridge: IUCN Species Survival Commission.

Johns, R. J. (1995). Malesia - An Introduction. Curtis's Bot. Mag. 12: 52-62.

KIEW, R. (1998). The unique elements of the limestone flora of the Batu Tengar Cave (Segarong), Sabah, Malaysia. Gard. Bull. Singapore 50: 185-196.

Léveillé, A. A. H. (1914). Flore du Kouy-Tchéou. Autographée en Partie par l'Auteur H. Léveillé. Le Mans.

McNeill, J., Barrie, F. R., Burdet, H. M., Demoulin, V., Hawksworth, D. L., Marhold, K., Nicolson, D. H., Prado, J., Silva, P. C., Skog, J. E., Wiersema, J. H. \& Turland, N. J. (2006). International Code of Botanical Nomenclature (Vienna Code) [Regnum Veg. vol. 146]. A.R.G. Gantner Verlag KG.

Middleton, D. J. (2003). Progress on the Flora of Thailand. Telopea 10: 33-42.

Nguyen, T. H. \& Kiew, R. (2000). New and interesting plants from Ha Long Bay, Vietnam. Gard. Bull. Singapore 52: 185-202.

Oliver, D. (1887). Phylloboea sinensis Oliv. Hook. Ic. Pl. 18: t.1721.

Pan, K. Y. (1988). Notulae de Gesneriaceis Sinensibus: 9. Acta Phytotax. Sin. 26: 429-442.

Pellegrin, F. (1930). Gesnéracées. In: Lecomte, M. H., Flore Générale de l'Indo-Chine 4: 487-565.

Poom A, R. (ed.) (2005). A preliminary checklist of threatened plants in Thailand. National Park, Wildlife and Plant Conservation Department, Bangkok.

Ridley, H. N. (1896). Cyrtandraceae Malayenses. J. Linn. Soc., Bot. 32: 497-528.

Ridley, H. N. (1905). The Gesneraceae of the Malay Peninsula. J. Straits Branch Roy. Asiat. Soc. 43: 1-92.

Ridley, H. N. (1929). New species from the Malay Peninsula and Borneo. Bull. Misc. Inform. Kew 1929: 254-262. 
Stapf, O. (1913). LVI - Decades Kewenses. Plantarum Novarum in Herbario Horti Regii Conservatum. Decas LXXXV. Bull. Misc. Inform. Kew 1913: 352-358.

Wang, W.-T., PAn, K.-Y. \& Li, Z.-Y. (1990). Gesneriaceae. Flora Reipublicae Popularis Sinicae 69: 125-581. Beijing: Science Press.

Weber, A. (1973). Die Struktur der paarblütigen Partialfloreszenzen der Gesneriaceen und bestimmter Scrophulariaceen. Beitr. Biol. Pflanzen 49: 429-460.

Weber, A. (1982). Evolution and radiation of the pair-flowered cyme in Gesneriaceae. Newslett. Austral. Syst. Bot. Soc. 30: 23-41.

Weber, A. (2004). Gesneriaceae. In: Kubitzki, K . \& Kadereit, J. W. (eds) The Families and Genera of Vascular Plants. Vol. 7. Dicotyledons. Lamiales (except Acanthaceae incl. Avicenniaceae). Berlin/Heidelberg: Springer.

Xu, Z. R. \& BuRtT, B. L. (1991). Towards a revision of Paraboea (Gesneriaceae): I. Edinburgh J. Bot. 48(1): 1-18.

Received 16 January 2008; accepted for publication 17 March 2008

\section{INDEX OF EXSICCATAE}

The number after each collection refers to the number of the taxon in the text.

Adisai 229 (37a); 670 (31); 972 (37a). Ahmad, S. \& Sidek, M. SAN581 (14a). Allen, B. s.n. (24). Allen, B. \& Kadim 501MK (14b); 502MK (63). Alphonso \& Samsuri A.88 (41); A.89 (41); A.241 (7). Ampuria, J. 35269SA (72). Anderson, J.A.R. 4721 (3); 7753 (17); 9078 (17); S16045 (83); S30906 (3); S31675 (7); S31822 (17); S31973 (38). Argent, G. \& Kerby 620 (17). Argent, G. et al. 651 (23); 738 (23); 908a (13); 1054 (6).

Balansa 4302 (56a); 4303 (79); 4304 (75); 4313 (84). Balgooy, M.M.J. van 2227 (1); 2701 (88). Balgooy, M.M.J. van et al. 5822 (51); 6010 (51). Banziger, H. 704 (31). Bartholomew, B. et al. (SINO-US) 1566 (71a); 1715 (75). Beijing Exp. 896886 (71a). Beusekom, C.F. et al. 3827a (10). Blume 182 (79); 241 (79). Bodinier, E. 2378 (50). Boey, J. 494 (26). Bon, R. P. 2501 (21); 2688 (84). Boonchuai, K. 948 (30). Bremer, B. \& Bremer 1697 (17). Brooke, W.M.A. 9904 (38); 10771 (17). Brooks, C.J. 1071 (38). Bruenig 10506 (13). Buennemeyer 2114 (20). Bunchuai, K. 968 (31); BKF47649 (31). Bunnak 710 (11). Bunpheng, D. 371 (37a); 663 (37a). Burkill, I.H. 6276 (14a). Burtt, B.L. 5578 (79); 5612 (56a); 8088 (38); 8097 (17); 8104 (17); 8152 (38); 8160 (17); 8214 (38); 8249 (23); 8263 (13); 8316 (6); 8333 (13); 8338 (23). Burtt, B.L. \& Martin 4748 (17); 4857 (62). Burtt, B.L. \& Woods, P.J.B. 1659 (12); 1661 (14a); 1664 (14b); 1686 (63); 1687 (14a); 1688 (89); 1722 (1); 1736 (1); 1737 (8); 1755 (1); 1761 (26); 1762 (26); 1763 (78); 1768 (41); 1774 (78); 1775 (22); 1776 (41); 1777 (1); 1795 (24); 1805 (41); 1809 (43); 1810 (41); 1821 (14b); 1822 (12); 1831 (17); 1832 (38); 1877 (17); 1928 (17); 1929 (38); 1992 (7); 2032 (83); 2091 (7); 2265 (52); 2278 (52); 2279 (13); 2281 (52); 2282 (52); 2309 (23); 2337 (17); 2347 (23); 2384 (23).

Cavalerie, J. s.n. (71a); 1783 (32); 2914 (75); 3145 (19); 3149 (75); 3620 (56a); 7409 (32); 7567 (71a). Cavalerie, J. et al. 2367 (75). Chaffanjon, B. s.n. (75); 560 (75); 2312 (75). Chai, P. s.n. (23); S39903 (23). Chai, P. \& Seng S22851 (38). Chandraprasong, K. 63 (4). Chan, Y.C. 21762 (1). Chand, T.R. 5977 (56a); 6394 (56a). Chang, Z.X. 8006 (71a). Chantaranothai, P. et al. 90/ 442 (37a). Charoenphol, C. et al. 3640 (11); 3642 (89). Chen, L.Q. 92733 (56a). Chen, S.C. 13048 (84). Chen, X.Q. 13224 (79). Chermsirivathana, C. 110 (37a). Chew, W.L. 1069 (23); 1108CW (17). Chin, S.C. 441 (9); 831 (14a); 1252 (88); 1409 (9); 1461 (83); 1785 (43). Ching, R.C. 6291 (79); 6371 (32); 6567 (71a); 6590 (32). Chou, H.C. 506 (75). Chow, H.C. s.n. (75). Chung, K.K. 1827 (71a). Clarke, C.B. 5536 (56a); 43839 (56a). Clemens \& Clemens 7627 (38); 
15851 (79); 20590 (17). Colani, E. 2937 (75). Coll, J.D. \& T. s.n. (56a). Collenette, J.S. 2356 (23). Collett, C.B. 804CB (58). Congdon 10 (80); 87 (24); 129 (42); 711 (24); 711a (54); 731 (42); 1249 (42). Cooper, R.E. 1026 (56a). Corner, E.J.H. s.n. (22); s.n. (43); s.n. (78); 37811 (78). Cult. in E s.n. (8); 146 (83); C3980 (89); C4029 (79); C4063 (43); C4071 (14b); C4087 (14b); C4088 (8); C4912 (12); C4918 (7); C5134 (14b); C5138 (31); C5978 (12); C6030 (17). Cult. in $W U$ s.n. (76). Curtis, C. s.n. (26); s.n. (43); s.n. (64); s.n. (70); s.n. (89); 2565 (78); 2566 (26); 2569 (41); 2571 (43); 2791 (1); 3039 (28); 3105 (60); 3107 (14b); 3134 (63); 3218 (64); 3682 (78); 3683 (22); 16010 (42).

D'Alleizette, A.C. s.n. (25). Den Hoed, G. 580 (37a). Dickason, F.G. 1093 (71b); 6000 (79). Donny JG et al. SBC1367 (38). Dransfield, J. \& Saerudin 2255 (40). Ducloux, F. 336 (71a); 2279 (58); 3712 (71a); 5572 (19); 6068 (58). Durant, C.C.L. 56251 (60); 56255KE (88).

Edaño, G. 48827 (79). Eddie, W.M.M. 1 (54); 2 (54); 3 (54). Elmer, A.D.E. 11145 (47). Endert, F.H. 1991 (74a); 5171 (40). Erwin \& Paul S27413 (17). Esquirol, J. s.n. (71a); 88 (71a); 317 (71a); 398 (75); 896 (71a); 1568 (75); 2699 (56a); 3086 (71a); 3756 (32); 3825 (71a); 4334 (71a); 6153 (71a). Evrard, M. 1177 (25).

Faber, E. 797 (19). Fang, D. \& Qin, D. H. 79634 (59). Fang, D. \& Zeng, L. 31379 (65). Fang, D. et al. 24985 (75); 79619 (50). Farges, R.P. s.n. (75); 1172 (75); 1192 (75). Fauquier, A. 554 (79). Fenix, E. 2107 (47); 15780BS (47); 24945 (47). Fidilis \& Sumbing, J. SAN135773 (72). Forbes, H.O. 3103 (83). Forrest, G. 15565 (75); 18259 (75); 18437 (75); 25309 (75). Fosberg, F.R. 43831 (17). FRI 1628 (88).

Gaerlan, F.J.M. \& Sagcal, E.C. PPI10037 (47). Gao, C.Z. \& Zhung 30491 (87). Gao, X.P. 52605 (21). Garrett, H.B.G. 204 (61); 1001 (30); 1260 (30). Geesink, R. \& Phengkhlai, C. 6084 (37a); 6105 (39). Geesink, R. et al. 5762 (71b). Gibot, A. SAN93025 (44). Godefroy-Lebeuf, M.C. 859 (18). Gressitt, J.L. 300 (79); 363 (79). Griffith 3843 (56a). Guangxi-Team 3303 (84). Guo, S.B. 80229 (21). Gutierrez et al. 1081 (47).

Haegens, R.M.A.P., Klazenga, N., Julaihi, L.C.J., Rantai et al. 337 (23). Hallier, H. 94 (74a). Handel-Mazzetti, H.F. von 714 (71a). Haniff, M. 1076 (1). Haniff, M. \& Curtis s.n. (43). Haniff, M. \& Mee 4192 (24). Haniff, M. \& Nur 7083 (43). Haniff, M. \& Nur, M. 4013 (70); 4026 (64). Hansen, C. 101 (23); 227 (52). Harmand s.n. (37a); 462 (37a); 547 (37b). Haviland, G.D. s.n. (17); 1460 (38); 3569 (83); 11724 (38). Hayata, B. 241 (79); 738 (25). Henderson, M.R. s.n. (12); 19459a (57); 19459b (83); SFN 19668 (9); SFN 21366 (43); SFN 23014 (1); SFN 25094 (5); SFN 29187 (43). Henry, A. s.n. (75); 691 (84); 897 (79); 897A (79); 3958 (75); 3960 (19); 4158 (75); 6017 (75); 6071 (75); 6363 (19); 8937 (79); 9318 (71a); 9836 (75); 9630 (75); 11223 (32); 11223A (75); 12162A (75); 12162B (75); 12305 (75); 12574 (61); 13385 (71a); 13394 (61); 21741 (21). Henry, B.C. 22137 (27). Hiep, N.T. NTH2108 (75). Hiep, N.T. \& Kiew, R. NTH4055 (36). Hoed, G.D. 946 (56b). Hooker, J.D. \& Hooker 2 (56a). Hotta, M. 14405 (17). Hou, D. 166 (48). Huang, Z. 40818 (21). Hutton, W. s.n. (20).

Ichlas, D. 112 (83). Ilias \& Azagari S35610 (20). IN 7 (54).

Jacobs, M. 5474 (17). James, M. et al. S37196 (38). Jamree et al. S82073 (17). Jermy, A.C. 14475 (52). Jiang, Z.D. \& Tao, G.F. 364 (75). Jong, K. \& Woods 4514 (60). Julaihi Lai S86866 (23). Jung, Y. s.n. (79).

Kasem 541 (10). Kelsall s.n. (88). Keng, H. 1382K (79). KEP 63169 (60); 71586 (24); 72557 (88); 79245 (60). Kerr, A.F.G. 205 (11); 1973 (79); 4629 (37a); 6356 (56a); 11067 (37a); 13362 (29); 16111 (54); 17575 (54); 19745 (11). Kiah, Y. 24376 (43). Kiew, R. RK 4318 (48). King's Collector 7108 (63); 8276 (12). Kjellberg, G.K. 2919 (45); 3938 (51). Koelz, W.N. 30371 (56a). Kondo, Y. \& Edano PNH36896 (47). Korthals 182 (79). Kostermans, A.J.G.H. 1450 (54); 1451 (37a); 13785 (7). Kostermans, A.J.G.H. \& Anta 619 (20); 1246 (20). Kunstler, H. 978 (14a). Kurz s.n. (67). Kurzweil 783HK (80); 784HK (42).

Lace, J.H. 130 (75); 4158 (75); 5501 (79); 5502 (75); 6273 (32). Larsen, K. 4078 (71b); 8311 (26); 8958 (10); 10536 (14a). Larsen, K. \& Larsen, S. 34145 (10). Larsen, K. et al. 1376 (37a); 5210 
(56a); 30949 (82); 31181 (82); 41034 (54); 41587 (11); 42391 (54); 42551 (89); 42569 (11); 44044 (1); 44124 (54); 44180 (54); 46840 (30). Lau, S.K. 27407 (35); 27597 (35); 28450 (71a). Laumonier, Y. $4312 \mathrm{TF}$ (83). Lehmann, P.F. 394 (17); 395 (38); S29441 (3). Leu, W.P. et al. 1433 (79). Li, C.T. 601176 (79). Li, G.F. 61192 (58). Li, H.J. 3851 (75). Li, M.K. 29 (71a). Li, Y.K. 1565P (32). Li, Z.X. \& Xing, F.W. 5134 (15). Li, Z. Y. et al. 425 (27). Liang, H. Y. 63102 (35). Liao \& Kuo 1636 (79). Liou, T.N. 13831 (58); 13970 (58); 20691 (58). Liu, T.R. 104 (21). Lobb, T. s.n. (17); 436 (56a). Loc, P.K. CBL1684 (79); CBL1784 (75); CBL1826 (75); CBL1894 (75). Loher, A. 1552 (79); 1552 (79); 6671 (79); 14825 (79).

MacGregor, R.W. 554 (75). Main (exp. E. Polak) 1991 (74a). Maire, R.P. s.n. (19); s.n. (19); s.n. (58); s.n. (75); s.n. (75). Malaise, R. 312 (31). Malcom, D. et al. SBC1140 (17). Marcan, A. 2388 (10). Martin, P.J. S39298 (17). Matthew, C.G. s.n. (41). Maxwell, J.F. 71-503 (37b); 71-666 (10); 73-103 (37a); 73-310 (68); 76-530 (68); 84-279 (54); 84-289 (54); 85-877 (11); 85-1101 (11); 86-451 (85); 86-599 (1); 86-651 (11); 87-1281 (56a); 89-992 (30); 93-1223 (37a); 95-857 (30); 97-830 (79). McNicoll s.n. (14a). Meijer, W. 7554 (83); 10850 (51); SAN23322 (cf. 44); SAN37962 (48). Merrill, E.D. 1754 (79); 4178 (47); 4209 (79); 8150 (47). Mg Gale, U. 12146 (31). Middleton, D.J. 4217 (84). Middleton, D.J. et al. 1180 (4); 1356 (37a). Mjöberg, E. s.n. (17). Mohtar, Abg. et al. S49645 (23). Mondi 129 (74b). Monok, C. \& Froideville 401 (45). Morse, H.B. 691 (84). Muraba, J. \& Yamazaki 9262 (71a). Murata, G. et al. T-14995 (71b); T-15072 (31); T-15185 (31); T-16164 (10).

Nanling Survey Exp. 121 (21). Native Collector s.n. (38); 14D (38); 399 (38); 1373 (38); 2070 (38); 2071 (17); 2553 (17). Nauen, J.C. 38021 (88). Ng, F.S.P. FRI 5568 (57). Nielsen, I. 729 (6). Nimanong, B. \& Phusomsaeng, S. 303 (10). Nur, M. 34366 (88).

Parnell, J.P. et al. 95-659 (10). Patsipun, Jugah et al. S79999 (17). Pételot, A. s.n. (49); s.n. (50a); s.n. (84); 711 (84); 711N (84); 1492 (75); 1505 (75); 1605 (75); 1624 (75); 2937 (75); 7242 (84). Phengkhlai, C. et al. 4222 (71b). Phusomsaeng, S. 5 (56a). Phusomsaeng, S. \& Bunchuai 44 (37a). Piajaporn 9 (54). Pierre, H.L. 4538 (37b); 4540 (70). Playfaio 6363 (79). Poilane, E. 1659 (84); 4676 (50a); 4751 (50a); 12188 (56a); 12770 (75); 16562 (32a); 18024 (68); 18948 (75); 20888 (25); 28717 (32a); 30612 (25); 32819 (33). Praphat, D. 8 (86); 24 (28). Prayad 1033 (37a); 1538 (10). Put 389 (71b); 430 (16); 1836 (10); 2426 (37a); 3199 (37a).

Qin, H.N. 81 (79); 425 (84). Quisumbing, T. BS78085 (79).

Rabil 103 (11); 106 (11); 123 (2); 301 (69); 331 (1). Ramos, M. 24076 (79); BS33147 (79). Ramos, M. \& Edaño, G. 107 (79); 29286 (79). Rao, W.Y. 79047 (71a). Raymond, S.B. \& Stephen, J.J. SBC3455 (17). Reid, S. KEP51676 (60); KEP51677 (88). Reillo, J. 16451 (47); BS16513 (47). Richards, P.W. s.n. (17). Ridley, H.N. s.n. (12); s.n. (24); 8551 (88); 11894 (14a); 72438 (17). Riedel s.n. (20). Robinson, H.C. 6223 (26). Robinson, H.C. \& Kloss 6062 (24).

S. P. et al. 17 (37a). Sakol 486 (37a); 1116 (10). Sang, J. et al. SBC2577 (17). Sangkhachand, P. 25 (56a); 1033 (37a). Sasaki, S. 380537 (79). Schneider, C. 483 (71a). Schoch, O. 286 (58). Seguin in Bodinier 509 (71a); 2377 (71a). Seidenfaden, G. \& T.S. 11629 (39). Shimizu, T. et al. T-2146 (10); T-21555 (10); T-27070 (86); T-27613 (54); T-27657 (54); T-27712 (54). Shing, L.H. FRI 17221 (57). Silva, F.D. 793 (56a). Simon, M. s.n. (71a). Sinclair, J. 5686 (17); 7833 (60); 9870 (14a); 9872 (60). Sino-Amer. Exp. 1566 (71a); 1715 (75). Sirirugsa, P. 328 (11). Smith, J.W. KEP79244 (88). Smitinand, T. 710 (11); 4689 (71b); 4728 (31); 11676 (68); 11935 (1). Smitinand, T. \& Floto 6106 (56a). Smitinand, T. \& Sleumer, H. 1130 (79); 1141 (4); 1289 (82). Smitinand, T. et al. 1036 (71b); 1277 (28); 1289 (82); 7824 (31). Soepadmo, E. \& Mahmud 1250 (78). Sorensen, T. et al. 1233 (71b); 3888 (79); 4077 (71b); 4078 (71b); 4543 (79); 5201 (56a); 7803 (56a). Sow \& Tachun KEP35093 (88). Steenis, C.G.G.J. van 9487 (60); 9503 (46). Stone, B.C. 6767 (cf. 44); 7307 (57); 7449a (9); 7449b (57); 9517 (83); 11007 (78); 11018 (43); 14206 (41); 14209 (41). Stone, S. \& Weber, A. 870427 (43). Sulit, M.D. \& Conklin 4774 (79). Sutheesorn, S. 2493 (37a). Suvarnakoses, P. 193 (11). Suzuki, S. 1475 (79). Swinhoe, R. 62 (79). Symington, C.F. KEP37429 (88); KEP39596 (88). Synge, P.M. S589 (83). 
Tagawa, M. et al. 1915 (37a). Tamura, M. \& Hotta 722 (48). Tan, S. \& Wright, E. S27279 (83). Tang, W.S. 566 (79). Teck, L.S. \& Rantai S66017 (17). Teruya, M. 130F (79). Teysmann s.n. (20); 8430 (74a). Thorel, M.L. 2268 (70); 2352 (81); 2353 (56a). Tsiang, Y. 8854 (75). Tsoong, K.K. 3725 (71a).

UNESCO Limestone Exp. 9 (14b); 154 (83); 303 (9); 429 (57); 560 (9); 593 (9).

Vavadavajan, G.S. et al. 1520 (47). Verma, D.M. 41776 (56a). Vesterdal, A. 7 (37a). Vidal y Soler, S. 3392 (47). Vriese, W.H. \& Teijsmann, J.E. 29 (53).

Wang, C. 41150 (79); 41202 (32); 41291 (71a). Wang, J.J. 4391 (79). Ward, F. K. 27460SF (11). Weber, A. 84-0802 (24); 86-0805 (8); 86-0806 (26); 86-0808 (24); 87-0508 (9); 87-0509 (9); 870510 (9); 87-0516 (5). Wei, Y.G. \& Zhong, S.H. 95-14 (34). Whitmore, T.C. 4251 (57); 4253 (9). Wilde, W.J.J.O. de \& Wilde-Duyfjes 12469 (46); 13639 (46); 14332 (73); 15747 (46); 16450 (60); 16590 (46); 16619 (46); 18968 (46). Williams, R.S. 938 (79). Wilson, E.H. s.n. (75); 507 (19); 859 (75); 876 (19); 1903 (19). Winit 740 (56a). Winkler, H. 522 (66); 672 (74a); 1488 (55). Wissmann, H. von 812 (71a). Wong et al. WKM 2864 (44). Wuang, C.T. 496 (21).

Xu, Z.R. L1132 (75); DH4492 (71a); NS4813 (75); LM4988 (19); LM4994 (50); GL7477 (50a). $X u, Z . R . \&$ Chen 3809GL (75).

Yii, P.C. \& Rantai et al. S66020 (38). Yii, P.C. \& Talib, A. S58809 (23); S58873 (23). Yii, P.C. et al. S50339 (17); S50385 (17). Yu, T.T. 17103 (75).

\section{INDEX OF SCIENTIFIC NAMES}

Accepted names are given in roman script, synonyms (and all excluded taxa) in italics, and new taxa and combinations in bold. The number after each name refers to the number of the accepted taxon. (exc) = Excluded taxa.

Boea acutifolia Ridl. (1)

Boea borneensis Scheff. ex H.O.Forbes (74a)

Boea brachycarpa Ridl. (9)

Boea brettiana W.W.Sm. (38)

Boea caerulescens Ridl. (12)

Boea chaffanjonii H.Lév. (75)

Boea cochinchinensis C.B.Clarke (18)

Boea crassifolia Hemsl. (19)

Boea dictyoneura Hance (21)

Boea divaricata Ridl. (22)

Boea elegans Ridl. (24)

Boea evrardii Pellegr. (25)

Boea ferruginea Ridl. (26)

Boea flocculosa C.B.Clarke (56a)

Boea glabra Ridl. (28)

Boea glabriflora Barnett (29)

Boea glabrisepala (B.L.Burtt) Barnett (30)

Boea glutinosa Hand.-Mazz. (32)

Boea hainanensis Chun (35)

Boea hancei C.B.Clarke (21)

Boea harroviana Craib (37a)

Boea havilandii Ridl. (38)

Boea kerrii Craib (79)

Boea lanata Ridl. (41)

Boea lancifolia Ridl. (42) 
Boea leporina H.J.Lam (45)

Boea macrophylla Drake (75)

Boea martinii H.Lév. (50)

Boea microcarpa Drake (56a)

Boea minahassae Teijsm. \& Binn. (53)

Boea minor Barnett (54)

Boea multiflora R.Br. (56a)

Boea multiflora var. burmannica C.B.Clarke (56a)

Boea multiflora var. villosa Pellegr. (56a)

Boea paniculata Ridl. (60)

Boea parviflora Ridl. (63)

Boea patens Ridl. (64)

Boea prolixa C.B.Clarke (67)

Boea reticulata Barnett (56a)

Boea rufescens Franch. (71a)

Boea rufescens var. seguinii (H.Lév. \& Vaniot) H.Lév. (71a)

Boea speciosa Rech. (76)

Boea speluncarum B.L.Burtt (77)

Boea suffruticosa Ridl. (78)

Boea swinhoei Hance (79)

Boea swinhoei var. diffusior C.B.Clarke (79)

Boea thirionii H.Lév. (56a)

Boea thorelii Pellegr. (81)

Boea treubii H.O.Forbes (83)

Boea umbellata Drake (84)

Boea verticillata Ridl. (88)

Buxiphyllum velutinum W.T.Wang \& C.Z.Gao (87)

Chlamydoboea sinensis (Oliv.) Stapf (75)

Chlamydoboea sinensis (Oliv.) Stapf forma macra Stapf (75)

Chlamydoboea sinensis (Oliv.) Stapf forma macrophylla Stapf (75)

Didymocarpus cordatus A.DC. (exc)

Didymocarpus detergibilis C.B.Clarke (20)

Didymocarpus minahassae (Teijsm. \& Binn.) H.O.Forbes (53)

Didymocarpus minutus Kraenzl. (55)

Didymocarpus multiflorus Wall. (56a)

Didymocarpus neurophyllus Collett \& Hemsl. (58)

Didymocarpus paraboea C.B.Clarke (17)

Didymocarpus paraboeoides Kraenzl. (74a)

Didymocarpus primuloides Kraenzl. (66)

Didymocarpus regularis Ridl. (70)

Didymocarpus schefferi H.O.Forbes (74a)

Didymocarpus schefferi var. ambigua C.B.Clarke (74b)

Didymocarpus seguinii H.Lév. \& Vaniot (71a)

Dorcoceras crassifolium (Hemsl.) Schltr. (19)

Dorcoceras rufescens (Franch.) Schltr. (71a)

Emarhendia bettiana (M.R.Hend.) Kiew (exc)

Henckelia alternifolia (C.B.Clarke) A.Weber (exc)

Henckelia densifolia (Ridl.) A.Weber (exc)

Henckelia floribunda (M.R.Hend.) A.Weber (exc)

Henckelia hirta (Ridl.) A.Weber (exc) 
Henckelia holttumii (M.R.Hend.) A.Weber (exc)

Henckelia leucocodon (Ridl.) A.Weber (exc)

Henckelia pyroliflora (Ridl.) A.Weber (exc)

Henckelia rubiginosa (Ridl.) A.Weber (exc)

Henckelia salicina (Ridl.) A.Weber (exc)

Henckelia scortechinii (Ridl.) A.Weber (exc)

Henckelia tahanica (B.L.Burtt) A.Weber (exc)

Henckelia tiumanica (Ridl.) A.Weber (exc)

Henckelia venusta (Ridl.) A.Weber (exc)

Oreocharis filipes Hance (27)

Paraboea acutifolia (Ridl.) B.L.Burtt (1)

Paraboea aff. glutinosa (32a)

Paraboea aff. martinii (50a)

Paraboea alternifolia (C.B.Clarke) B.L.Burtt (exc)

Paraboea amplifolia Z.R.Xu \& B.L.Burtt (2)

Paraboea apiensis Z.R.Xu (3)

Paraboea argentea Z.R.Xu (4)

Paraboea bakeri M.R.Hend. (5)

Paraboea banyengiana B.L.Burtt (6)

Paraboea barbartipes K.Y.Pan (50)

Paraboea berouwensis Z.R.Xu \& B.L.Burtt (7)

Paraboea bettiana M.R.Hend. (exc)

Paraboea bintangensis B.L.Burtt (8)

Paraboea brachycarpa (Ridl.) B.L.Burtt (9)

Paraboea brunnescens B.L.Burtt (10)

Paraboea burttii Z.R.Xu (11)

Paraboea caerulea Ridl. (exc)

Paraboea caerulescens (Ridl.) B.L.Burtt (12)

Paraboea campanulata Ridl. (exc)

Paraboea candidissima B.L.Burtt (13)

Paraboea capitata Ridl. (14a)

Paraboea capitata var. oblongifolia Ridl. (14b)

Paraboea changjiangensis F.W.Xing \& Z.X.Li (15)

Paraboea chiangdaoensis Z.R.Xu \& B.L.Burtt (16)

Paraboea clarkei B.L.Burtt (17)

Paraboea clavisepala D.Fang \& D.H.Qin (50)

Paraboea cochinchinensis (C.B.Clarke) B.L.Burtt (18)

Paraboea cordata (A.DC.) Ridl. (exc)

Paraboea crassifolia (Hemsl.) B.L.Burtt (19)

Paraboea culminicola K.G.Pearce (83)

Paraboea curtisii Ridl. (14a)

Paraboea densifolia (Ridl.) M.R.Hend. (exc)

Paraboea detergibilis (C.B.Clarke) B.L.Burtt (20)

Paraboea dictyoneura (Hance) B.L.Burtt (21)

Paraboea divaricata (Ridl.) B.L.Burtt (22)

Paraboea effusa B.L.Burtt (23)

Paraboea elegans (Ridl.) B.L.Burtt (24)

Paraboea evrardii (Pellegr.) B.L.Burtt (25)

Paraboea ferruginea (Ridl.) Ridl. (26)

Paraboea filicifolia (Ridl.) Ridl. (exc) 
Paraboea filipes (Hance) B.L.Burtt (27)

Paraboea floribunda M.R.Hend. (exc)

Paraboea glabra (Ridl.) B.L.Burtt (28)

Paraboea glabriflora (Barnett) B.L.Burtt (29)

Paraboea glabrisepala B.L.Burtt (30)

Paraboea glanduliflora Barnett (31)

Paraboea glutinosa (Hand.-Mazz.) K.Y.Pan (32)

Paraboea grandifolia Ridl. (exc)

Paraboea graniticola Z.R.Xu (33)

Paraboea guilinensis L.Xu \& Y.G.Wei (34)

Paraboea hainanensis (Chun) B.L.Burtt (35)

Paraboea halongensis Kiew \& T.H.Nguyên (36)

Paraboea harroviana (Craib) Z.R.Xu (37a)

Paraboea harroviana var. ovata Z.R.Xu (37b)

Paraboea havilandii (Ridl.) B.L.Burtt (38)

Paraboea holttumii M.R.Hend. (exc)

Paraboea incudicarpa B.L.Burtt (39)

Paraboea kalimantanensis Z.R.Xu \& B.L.Burtt (40)

Paraboea kerrii (Craib) B.L.Burtt (79)

Paraboea lanata (Ridl.) B.L.Burtt (41)

Paraboea lancifolia (Ridl.) B.L.Burtt (42)

Paraboea laxa Ridl. (43)

Paraboea leopoldii K.M.Wong, J.T.Pereira, Sugau \& S.P.Lim (44)

Paraboea leporina (H.J.Lam) B.L.Burtt (45)

Paraboea leucocodon Ridl. (exc)

Paraboea leuserensis B.L.Burtt (46)

Paraboea luzoniensis Merr. (47)

Paraboea madaiensis Z.R.Xu \& B.L.Burtt (48)

Paraboea mahaxayana Z.R.Xu \& B.L.Burtt (49)

Paraboea martinii (H.Lév.) B.L.Burtt (50)

Paraboea mataensis Z.R.Xu \& B.L.Burtt (51)

Paraboea meiophylla B.L.Burtt (52)

Paraboea microcarpa (Drake) B.L.Burtt (56a)

Paraboea minahassae (Teijsm. \& Binn.) B.L.Burtt (53)

Paraboea minor (Barnett) B.L.Burtt (54)

Paraboea minuta (Kraenzl.) B.L.Burtt (55)

Paraboea multiflora (R.Br.) B.L.Burtt (56a)

Paraboea multiflora var. caulescens Z.R.Xu \& B.L.Burtt (56b)

Paraboea nagalandiana Deb \& Dutta (exc)

Paraboea nervosissima Z.R.Xu \& B.L.Burtt (57)

Paraboea neurophylla (Collett \& Hemsl.) B.L.Burtt (58)

Paraboea nutans D.Fang \& D.H.Qin (59)

Paraboea obovata Ridl. (24)

Paraboea paniculata (Ridl.) B.L.Burtt (60)

Paraboea paraboeoides (Kraenzl.) B.L.Burtt (74a)

Paraboea paramartinii Z.R.Xu \& B.L.Burtt (61)

Paraboea paraprimuloides Z.R.Xu (62)

Paraboea parviflora (Ridl.) B.L.Burtt (63)

Paraboea patens (Ridl.) B.L.Burtt (64)

Paraboea peltifolia D.Fang \& L.Zeng (65) 
Paraboea polita Ridl. (14a)

Paraboea primuloides Z.R.Xu (66)

Paraboea prolixa (C.B.Clarke) B.L.Burtt (67)

Paraboea pubicorolla Z.R.Xu \& B.L.Burtt (68)

Paraboea pubiflora Ridl. (exc)

Paraboea pyroliflora (Ridl.) Ridl. (exc)

Paraboea rabilii Z.R.Xu \& B.L.Burtt (69)

Paraboea regularis (Ridl.) Ridl. (70)

Paraboea ridleyi Elmer (47)

Paraboea rubiginosa Ridl. (exc)

Paraboea rufescens (Franch.) B.L.Burtt (71a)

Paraboea rufescens var. tomentosa (Barnett) Z.R.Xu (71b)

Paraboea rufescens var. umbellata (Drake) K.Y.Pan (84)

Paraboea rupestris B.L.Burtt (28)

Paraboea sabahensis Z.R.Xu \& B.L.Burtt (72)

Paraboea salicina (Ridl.) Ridl. (exc)

Paraboea scabriflora B.L.Burtt (73)

Paraboea schefferi (H.O.Forbes) B.L.Burtt (74a)

Paraboea schefferi var. ambigua (C.B.Clarke) Z.R.Xu (74b)

Paraboea scortechinii Ridl. (exc)

Paraboea sinensis (Oliv.) B.L.Burtt (75)

Paraboea speciosa (Rech.) B.L.Burtt (76)

Paraboea speluncarum (B.L.Burtt) B.L.Burtt (77)

Paraboea suffruticosa (Ridl.) B.L.Burtt (78)

Paraboea swinhoei (Hance) B.L.Burtt (79)

Paraboea tarutaoensis Z.R.Xu \& B.L.Burtt (80)

Paraboea thirionii (H.Lév.) B.L.Burtt (56a)

Paraboea thorelii (Pellegr.) B.L.Burtt (81)

Paraboea tiumanica Ridl. (exc)

Paraboea tomentosa Barnett (71b)

Paraboea trachyphylla Z.R.Xu \& B.L.Burtt (82)

Paraboea treubii (H.O.Forbes) B.L.Burtt (83)

Paraboea tribracteata D.Fang \& W.Y.Rao (71a)

Paraboea umbellata (Drake) B.L.Burtt (84)

Paraboea uniflora Z.R.Xu \& B.L.Burtt (85)

Paraboea variopila Z.R.Xu \& B.L.Burtt (86)

Paraboea velutina (W.T.Wang \& C.Z.Gao) B.L.Burtt (87)

Paraboea verticillata (Ridl.) B.L.Burtt (88)

Paraboea vulpina Ridl. (89)

Phylloboea henryi Duthie ex Beddome (71a)

Phylloboea sinensis Oliv. (75) 